Mechanistic Studies on Reactivities of organometallic Macrocyclic Complexes of Chromium and cobalt

by

Shi, Shu

PHD Thesis submitted to Iowa State University

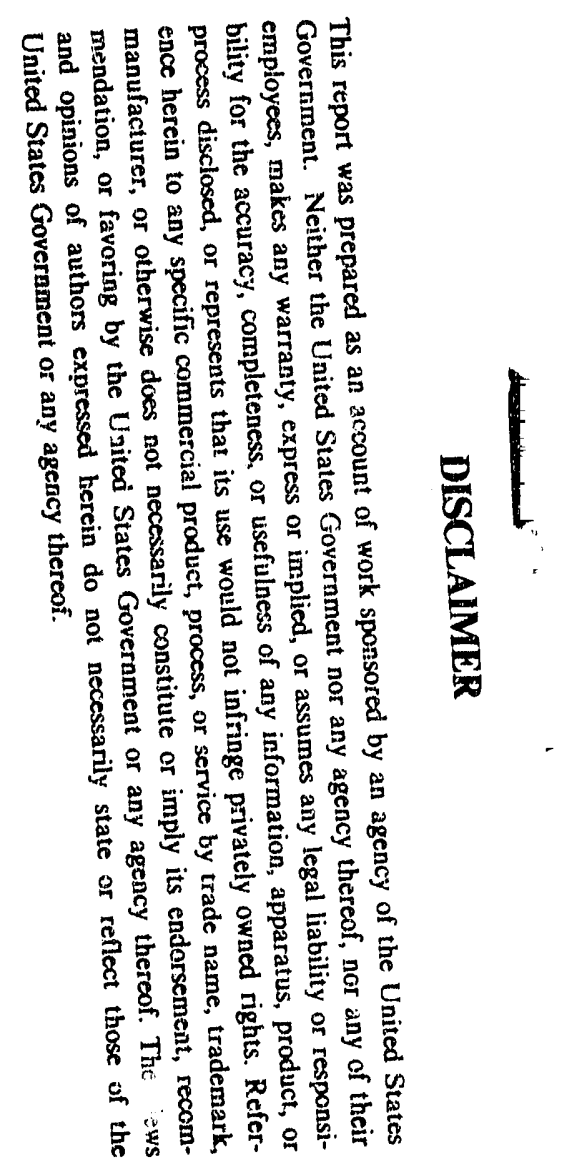

UNDER CONTRACT NO. W-7405-ENg-82. 


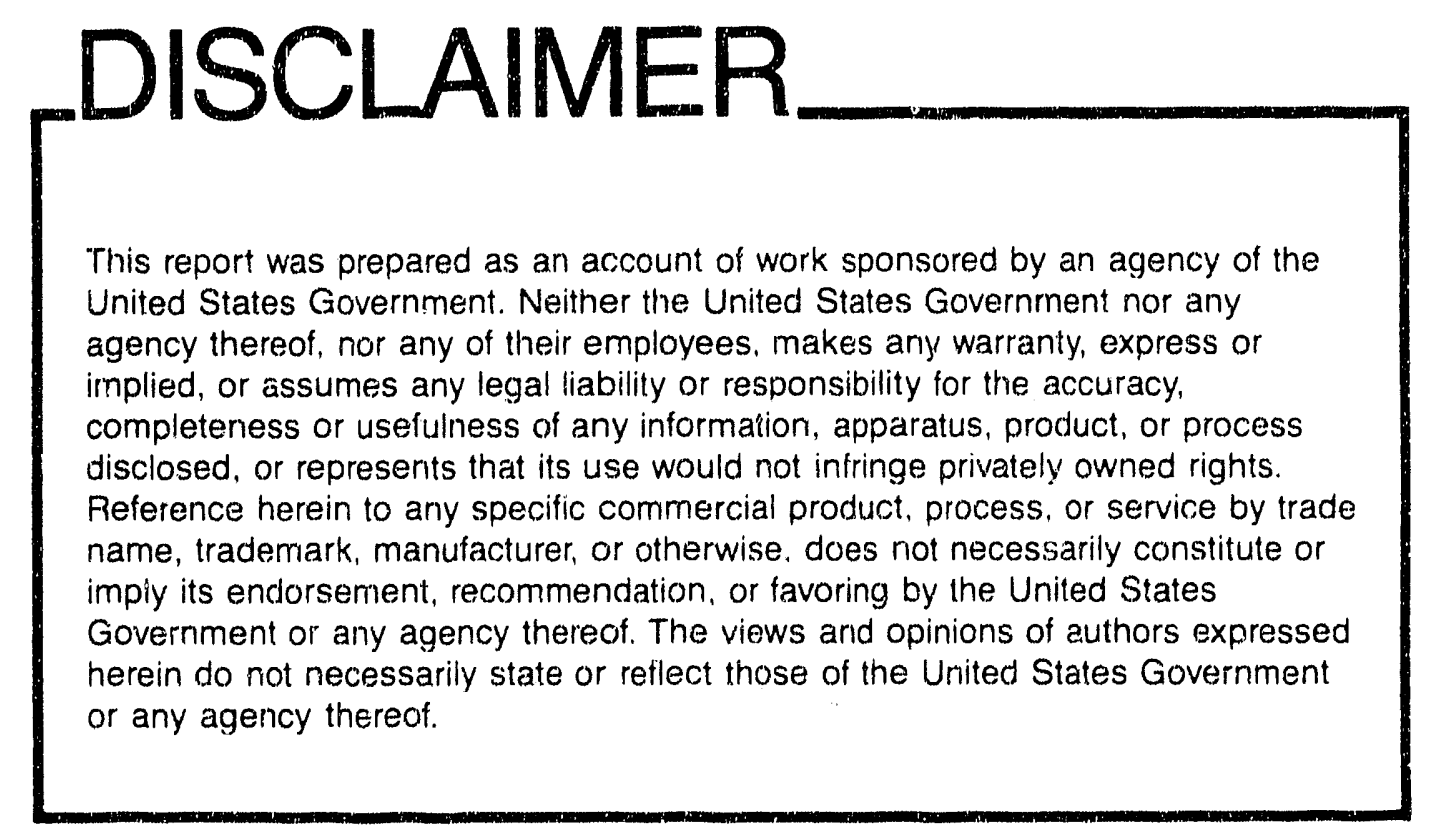

Printed in the United States of America

Available from

National Technical information Service

U.S. Department of Commerce

5265 Port Royal Road

Springfield. VA 22161 


\title{
Mechanistic studies on reactivities of organometallic macrocyclic complexes of chromium and cobalt
}

Shu Shi

\author{
Under the supervision of James H. Espenson \\ From the Department of Chemistry \\ Iowa State University
}

Reaction pattiways leading to the formation and cleavage of a transition metal-carbon bond at various oxidation states of the metal occupy a central position in understanding many enzymatic reactions and designing catalysts.

Part I focuses on the homolysis vs, heterolysis of a $\mathrm{C}-\mathrm{Cr}$ (III) bond. Rate constants of homolysis and heterolysis of the C-Cr(III) bonds along with corresponding $\Delta H^{\dagger}$ and $\Delta S^{\neq}$were measured by ESR and stopped flow techniques. Factors favoring one pathway over another to cleave a C-Cr(III) bond are discussed.

Part II describes a unique chain reaction and a $S_{E} 2$ reaction between $\mathrm{I}_{2}$ and $\mathrm{RCr}^{2+}$. The nolecular structure of $\mathrm{RCrL}^{2+}$, determined by $x$-ray diffraction for the first time, provides clearly a structural basis for the reactivity discussions.

Part III concerns the oxidation of organochromium(III) complexes by dihalide and pseudo-dihalide radical anions generated by pulse radiolysis. The reaction mechanism and reactivity trend are discussed. 
Paic IV concentrates on the oxidation mechanism of $\mathrm{RCrL}\left(\mathrm{H}_{2} \mathrm{O}\right)^{2+}$ and the fate of $\mathrm{RCr}\left(\mathrm{H}_{2} \mathrm{O}\right)^{3+}$ as well as the corresponding reduction potentials. An outer-sphere electron transfer mechanism was established. A facile C-Cr(IV) bond hemolyses was discovered along with its negligible heterolysis. Reduction potential of $\mathrm{E}_{1 / 2}(\mathrm{RCr} I \mathrm{IV} / \mathrm{RCr} I I I)$ and the relavent self exchange rate constant $k_{11}$ were estimated by a kinetic method.

In Part $V$ the study is extended to organocobalt complexes with attention turned to reduction induced cleavages of a transition metalcarbon bond. Electrochemical methods in conjunction with ESR, NMR, and GC-MASS are used to reveal evidence of novel reactions - reduction induced hydrogen atom transfer and reduction induced alkyl group migration. Part $\mathbf{V}$ also concerns the kinetics of reductions of the organocobalt compounds by a nickel(I) complex.

In Part VI, the crystallization of $\left[\left(\mathrm{CH}_{3}\right)_{4} \mathrm{~N}\right]\left[\mathrm{Co}(\mathrm{dmgBF})_{2}\right.$ py $]$ and its molecular structure determined by $X$-ray diffraction are described. The $\mathrm{Co}^{\mathrm{I}}-\mathrm{N}_{\mathrm{eq}}$ distances are unusually short $(1.839 \AA)$, even shorter than the corresponding bond $(1.878 \AA)$ in the cobalt(II) analogue. Reasons of this unusual $\mathrm{CO}-\mathrm{N}$ bond shortening is discussed along with the electronic structure of the $d^{8}$ cobalt(I) anion. 


\section{Mechanistic studies on reactivities of organometallic} macrocyclic complexes of chromium and cobalt

Shu Shi

A Dissertation Submitted to the

Graduate Faculty in Partial Fulfillment of the

Requirements for the Degree of

DOCTOR OF PHILOSOPHY

Department: Chemistry

Major: Inorganic Chemistry

Approved:
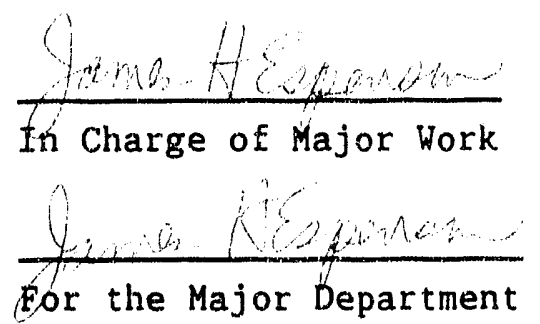

For the Graduate College

$$
\begin{aligned}
& \text { Iowa State University } \\
& \text { Ames, Iowa }
\end{aligned}
$$


TABLE OF CON"ENTS

GENERAL INTRODUCTION $\ldots \ldots \ldots \ldots \ldots \ldots \ldots \ldots \ldots \ldots \ldots \ldots \ldots$

PART I. ORGANOCHROMIUM(III) MACROCYCLIC COMPLEXES.

FACTORS CONTROLLING HOMOLYTIC VS. HETEROLTTIC

CLBAVAGE OF THE CHROMIUA-CARBON BOND $\ldots \ldots \ldots \ldots \ldots$

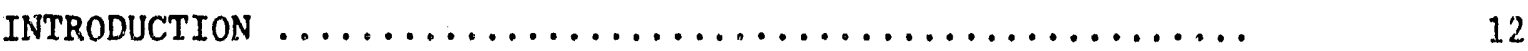

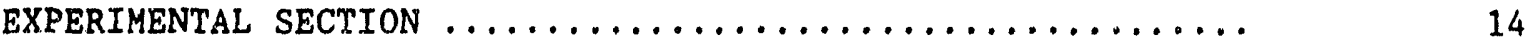

Materials .............................. 14

Techniques $\ldots \ldots \ldots \ldots \ldots \ldots \ldots \ldots \ldots \ldots \ldots \ldots \ldots \ldots \ldots$

Kinetic Measurements ...................... 15

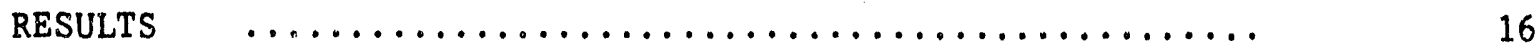

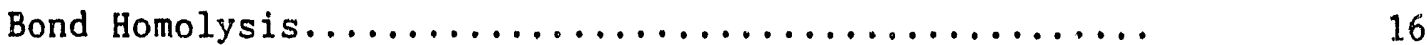

Trans Effect on Homolysis of the Hydroxo Complexes ....

Temperature Dependence of Homolysis Rate Constants..... 18

Heterolytic Cleavage of the $\mathrm{Cr}-\mathrm{C}$ Bond................ 19

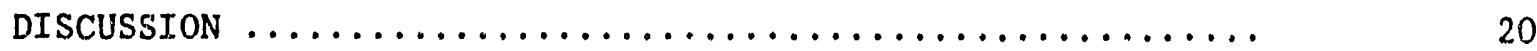

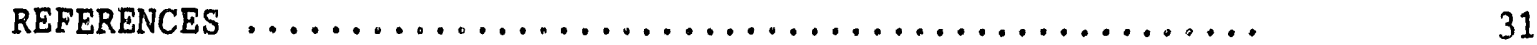

PART II. STRUCTURE AND REACTIVITY OF ORGANOCHROMIUM MACROCYCLES VITE IODINE BY CHAIN AND ELECTROPHILIC MECHANISHS $\ldots \ldots \ldots \ldots \ldots \ldots \ldots \ldots$ 


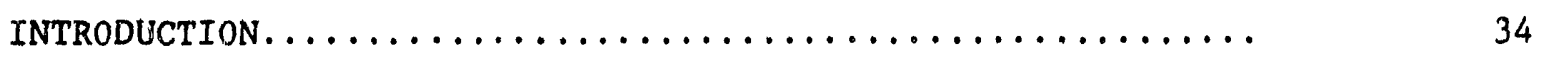

EXPERIMENTAL SECTION........................ 36

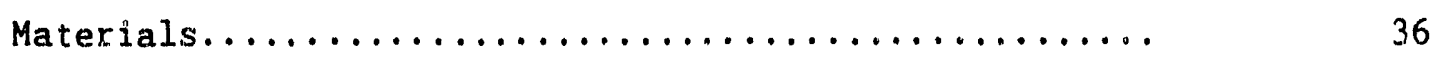

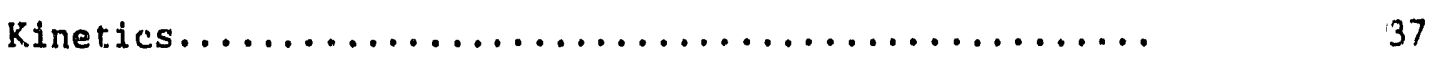

Crystal Growth........................... 37

$X$-Ray Data and Structure..................... 38

Spectrum and Product Analysis.................. 38

RESULTS AND DISCUSSION...................... 40

Formation of $4-\mathrm{BrC}_{6} \mathrm{H}_{4} \mathrm{CH}_{2} \mathrm{CrL}\left(\mathrm{H}_{2} \mathrm{O}\right)^{2+} \ldots \ldots \ldots \ldots \ldots \ldots \ldots$

The Crystal structure of

$\left[\mathrm{p}-\mathrm{BrC}_{6} \mathrm{H}_{4} \mathrm{CH}_{2} \mathrm{CrL}\left(\mathrm{H}_{2} \mathrm{O}\right)\right]\left(\mathrm{ClO}_{4}\right)_{2}$. THF $\ldots \ldots \ldots \ldots \ldots \ldots \ldots, 41$

Electrophilic Subsitution Reaction with Iodine....... 42

Chain Reaction between $4-\mathrm{BrC}_{6} \mathrm{H}_{4} \mathrm{CH}_{2} \mathrm{CrL}\left(\mathrm{H}_{2} \mathrm{O}\right)^{2+}$

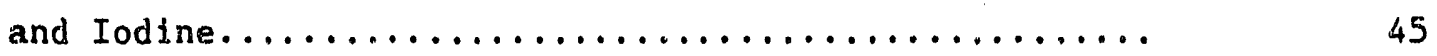

Bimolecular Electrophilic Substitution Reaction

between $4-\mathrm{BrC}_{6} \mathrm{H}_{4} \mathrm{CH}_{2} \mathrm{CrL}\left(\mathrm{H}_{2} \mathrm{O}\right)^{2+}$ and Iodine.......... 50

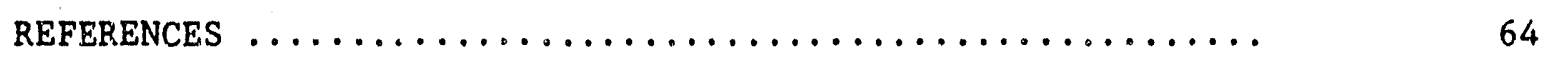

\section{PART III. REACTIVITY OF ORGANOCHROMIUM COMPLEXES TOWARD} INORGANIC RADICALS. A PULSE RADIOLYSIS STUDY .... 66

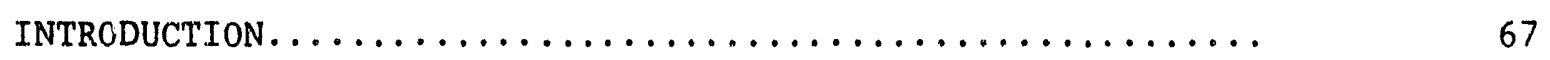

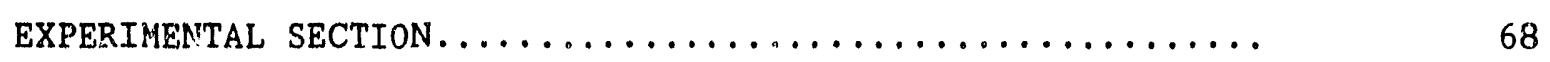

Reagents.............................. 68

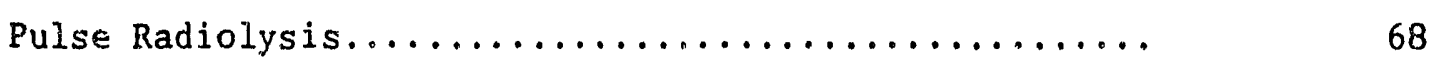

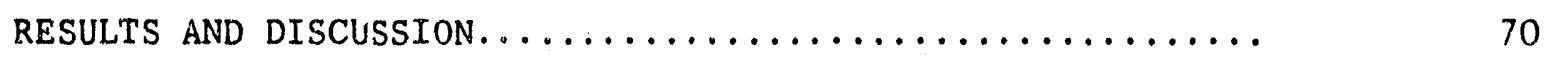


PART IV. REVERSIBLE ELECTRON TRANSFER REACTIONS OF ORGANOCEROHIUM(III) MACROCYCLIC COMPLEXES

EXPERIMENTAL SECTION.

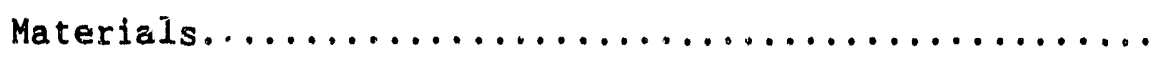

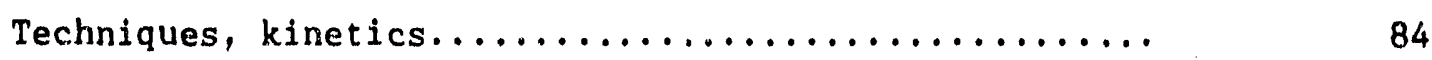

RESULTS AND DISCUSSION. ..................... 85

Reaction of $4-\mathrm{BrC}_{6} \mathrm{H}_{4} \mathrm{CH}_{2} \mathrm{CrL}\left(\mathrm{H}_{2} \mathrm{O}\right)^{2+}$ with $\mathrm{ABTS} \cdot-\ldots \ldots \ldots$.

Oxidation of $4-\mathrm{BrC}_{6} \mathrm{H}_{4} \mathrm{CH}_{2} \mathrm{CrL}\left(\mathrm{H}_{2} \mathrm{O}\right)^{2+}$ by $\mathrm{IrCl}_{6} 2-$

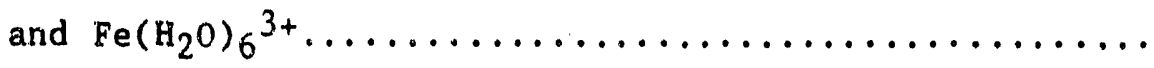

Analysis of Oxidation Rates on the Basis of the

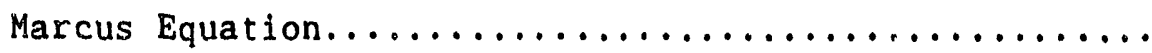

The Reduction Potential, Lifetime and Self-Exchange

Rate of $\mathrm{RCrL}\left(\mathrm{H}_{2} \mathrm{O}\right)^{3+\ldots \ldots \ldots \ldots \ldots \ldots \ldots \ldots \ldots \ldots \ldots \ldots \ldots \ldots}$

oxidation of Various $\mathrm{RCrL}\left(\mathrm{H}_{2} \mathrm{O}\right)^{2+}$ Complexes

by $\operatorname{IrCl}_{6}{ }^{2}-\ldots \ldots \ldots \ldots \ldots \ldots \ldots \ldots \ldots \ldots \ldots \ldots \ldots \ldots \ldots \ldots \ldots \ldots \ldots$

REFERENCES $\ldots \ldots \ldots \ldots \ldots \ldots \ldots \ldots \ldots \ldots \ldots \ldots \ldots \ldots \ldots \ldots \ldots \ldots \ldots \ldots$

PART V. REDUCTION INDUCED COBALT-CARBON BOND CLEAVAGE IN ORGANOCOBALT MACROCTCLIC COMPLEXES .........

INTRODUCTION............................. 102

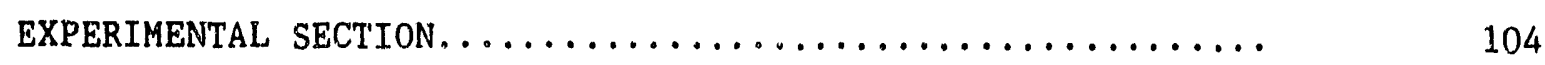


Materials................................ 104

Electrochemical Reduction................... 104

Product Analysis.......................... 105

Spectroscopic studies........................ 105

Kinetics.............................. 106

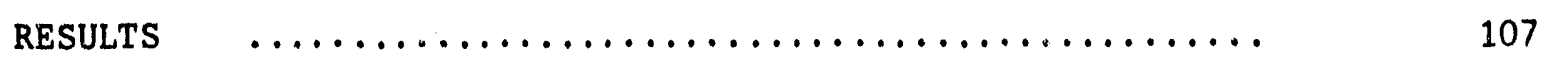

Reduction Induced Decompositions................ 107

Participation of the Equatorial Ligand............. 108

Kinetics of the Reduction of $\mathrm{RCo}\left(\mathrm{dmgBF}_{2}\right)_{2} \mathrm{~A}$

by $\mathrm{Ni}(\mathrm{tmc})+\ldots \ldots \ldots \ldots \ldots \ldots \ldots \ldots \ldots \ldots \ldots \ldots \ldots \ldots$

DISCUSSION $\ldots \ldots \ldots \ldots \ldots \ldots \ldots \ldots \ldots \ldots \ldots \ldots \ldots \ldots \ldots \ldots \ldots \ldots \ldots \ldots$

Reduction Induced Decompositions................ 111

Participation of the Equatorial Ligand............ 113

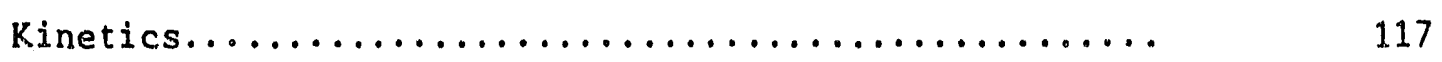

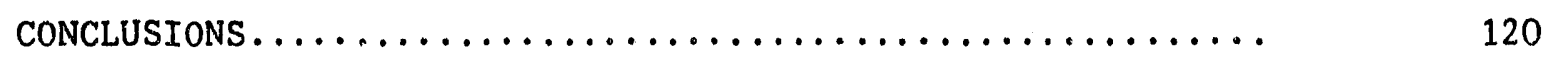

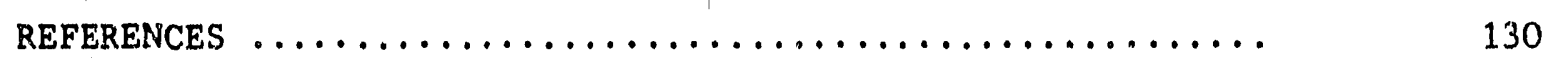

PART VI. MOLECULAR STRUCTURE OF A COBALT(I) COMPLEX

LACRING A CARBONYL LIGAND. A UNIQUE EXAMPLE OF

Co-N BOND SHORTENING $\ldots \ldots \ldots \ldots \ldots \ldots \ldots \ldots \ldots$

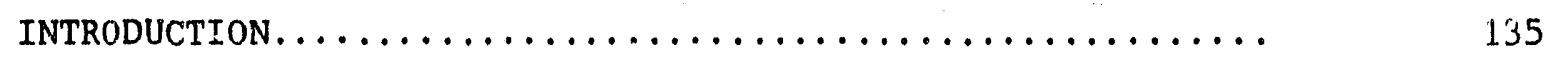

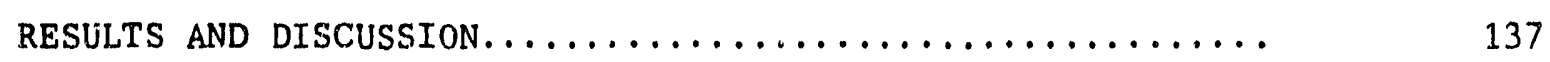

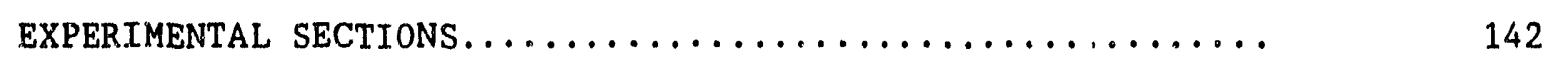

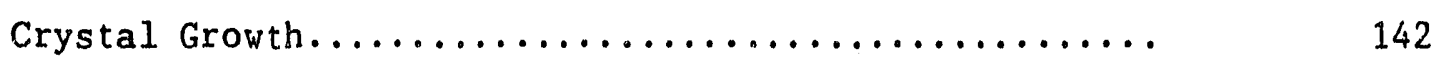

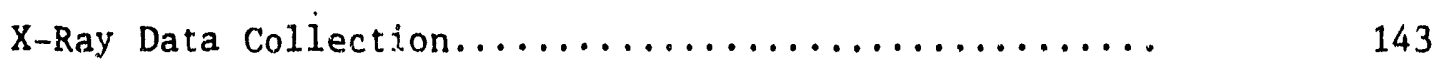




\section{GENERAL INTRODUCTION}

Part I: Organochromium(III) Macrocycles. Controlled Homolytic vs. Heterolytic Scission of the $\mathrm{Cr}$ (III)-C Bond.

Reason to Study: Little is known about the factors that alternate pathways of the cleavage of a metal-carbon bond (homolysis vs. heterolysis) in dark reactions. A full understanding of these factors could lead to new means to control the release of free radicals from. their precursors in many chemical processes.

Corclusion: Factors that make a M-C bond more polar tend to inhibit homolysis and enhance heterolysis. Alternation of the pathways can be achieved by modification of the $\mathrm{R}$ group, equatorial ligand $\mathrm{L}$, and trans group $A$ (of $\left.\operatorname{RML}(A)^{n+}\right)$. According to this understanding, a molecular "swirch" has been successfully built into an organochromium complex for the first time to control the pathway of the scission of a $\mathrm{Cr}-\mathrm{C}$ bond. (A water molecule was put at the position trans to a $\mathrm{Cr}-\mathrm{C}$ bond as in $\mathrm{RCrL}\left(\mathrm{H}_{2} \mathrm{O}\right)^{2+}$ complexes, and its deprotonation (to $\mathrm{RCrL}(\mathrm{OH})^{+}$) and reprotonation was used to "switch" off and on the homolysis and heterolysis of the $\mathrm{Cr}-\mathrm{C}$ bond, i.e., $\mathrm{RCrL}\left(\mathrm{H}_{2} \mathrm{O}\right)^{2+}+\mathrm{H}_{2} \mathrm{O} \rightarrow \mathrm{R} \cdot+$ $\left.\mathrm{CrL}\left(\mathrm{H}_{2} \mathrm{O}_{2}{ }^{2+} ; \mathrm{RCrL}(\mathrm{OH})^{+}+\mathrm{H}_{2} \mathrm{O} \rightarrow \mathrm{RH}+\mathrm{CrL}(\mathrm{OH})_{2}\right)\right)$. Replacement of the macrocyclic ligand $\mathrm{L}$ by $\mathrm{H}_{2} \mathrm{O}$ at equatorial positions (i.e., $\mathrm{RCr}\left(\mathrm{H}_{2} \mathrm{O}\right)_{5}{ }^{2+}$ vs. $\mathrm{RCrL}\left(\mathrm{H}_{2} \mathrm{O}^{2+}\right)$ decreases $\mathrm{Cr}-\mathrm{C}$ bond polarity and thus largely enhances the homolysis of the $\mathrm{Cr}-\mathrm{C}$ bond (both in terms of rate constant, $k_{h}$, and 
in terms of Hammett coefficient, $\rho)$. The parallel relationship between bond polarity and the change of decomposition pathway can be understood in terms of orbital energy difference $\Delta E=E\left[e_{g}{ }^{*}(\mathrm{Cr})\right]-E[\sigma(R)]$ since $\Delta E$ controls the $\mathrm{Cr}-\mathrm{C}$ bond polarity and the susceptibility of the internal electron transfer (from a formal carbanion to a formal chromium(III) as shown in eq (1)) which accompanies the homolysis.

The reaction scheme is shown in eqs (1) and (2),

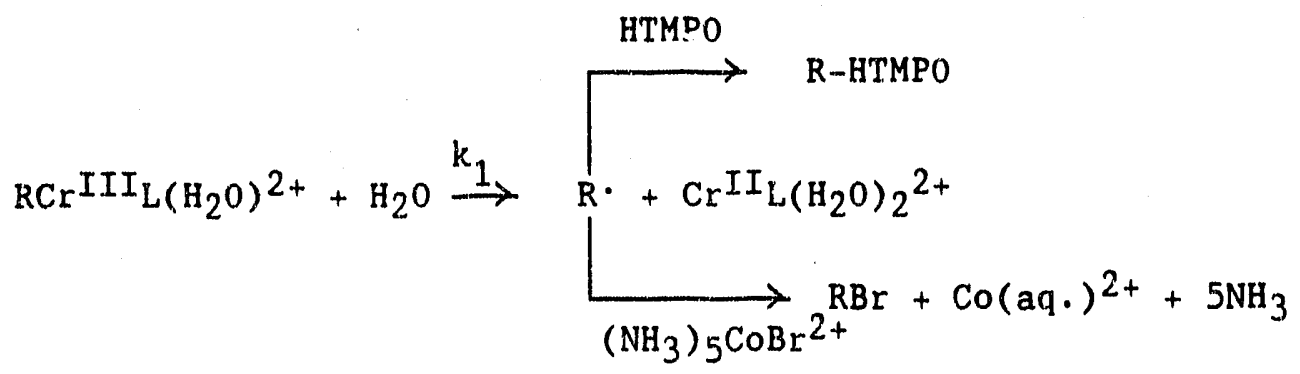

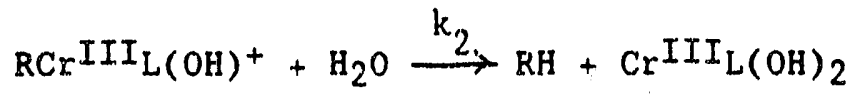

(where $\mathrm{R}=\mathrm{CH}_{3}, \mathrm{C}_{2} \mathrm{H}_{5}, 1-\mathrm{C}_{3} \mathrm{H}_{7}, 1-\mathrm{C}_{4} \mathrm{H}_{9}, 2-\mathrm{C}_{3} \mathrm{H}_{7}, 2-\mathrm{C}_{4} \mathrm{H}_{9}, 4-\mathrm{CH}_{3} \mathrm{C}_{6} \mathrm{H}_{4} \mathrm{CH}_{2}$, $\mathrm{C}_{6} \mathrm{H}_{5} \mathrm{CH}_{2}, 4-\mathrm{BrC}_{6} \mathrm{H}_{4} \mathrm{CH}_{2}$ ).

$\mathrm{RCrL}\left(\mathrm{H}_{2} \mathrm{O}\right)^{2+}$ was prepared by radical capture reaction,

$$
\begin{aligned}
& \mathrm{RX}+\mathrm{CrL}\left(\mathrm{H}_{2} \mathrm{O}\right)_{2}{ }^{2+} \rightarrow \mathrm{R} \cdot+\mathrm{XCrL}\left(\mathrm{H}_{2} \mathrm{O}\right)^{2+} \\
& \mathrm{R} \cdot+\mathrm{CrL}\left(\mathrm{H}_{2} \mathrm{O}\right)_{2}{ }^{2+} \rightarrow \mathrm{RCrL}\left(\mathrm{H}_{2} \mathrm{O}\right)^{2+}+\mathrm{H}_{2} \mathrm{O},
\end{aligned}
$$

( $L=[15]$ aneN 4 or $\left.\left(\mathrm{H}_{2} \mathrm{O}\right)_{4}\right)$ and purified by ion-exchange. Due to the existence of the back reaction of eq (1) radical scavengers (HTMPO or $\mathrm{BrCo}\left(\mathrm{NH}_{3}\right)_{5}{ }^{2+}$ ) were used to draw the homolysis to completion. The $k_{1}$ step is rate limiting. Reactions were monitored by ESR and spectrophotometry. 
Products were detected by GC and UV-Vis spectra. The heterolysis rate is independent of $\left[\mathrm{OH}^{-}\right]$and $\left[\mathrm{H}_{3} \mathrm{O}^{+}\right]$, and has no $\mathrm{D} / \mathrm{H}$ isotope effect, confirming that $k_{2}$ step is unimolecular. So both $\Delta H_{1}^{\phi_{1}}$ and $\Delta \mathrm{H}^{t_{2}}$ represent fairly good estimations of the $\operatorname{Cr}($ III)-C bond enthalpies toward homolysis and heterolysis iespectively. $k_{i}(i=1,2)$ of various $\operatorname{RCrL}\left(\mathrm{H}_{2} \mathrm{O}\right)^{2+}$ and $\mathrm{RCrL}\left(\mathrm{OH}_{i}+\right.$ ware measured at $25{ }^{\circ} \mathrm{C}$, and $\Delta \mathrm{H}^{\dagger}{ }_{1}, \Delta \mathrm{S}_{1}{ }_{1}$ were obtained by temperature dependence of kinetic measurements leading to the above conclusions.

Part II: Mechanistic Study of the Organochromium Macrocyclic Complexes/I 2 Reactions.

Reason to study: Little is known about chain reactions in which an oxidation-induced $M-C$ bond homolysis is involved to sustain the chain. Fundamental knowledge of such reactions is badly needed to understand reactivities of $M-C$ bonds fulily.

Conclusion: The first example that an oxidation induced $M-C$ bond homolysis serves to sustain a chain reaction was demonstrated by this stindy. The overall rate law is,

$-d\left[\operatorname{RCrL}\left(\mathrm{H}_{2} \mathrm{O}\right)^{2+}\right] / d t=k_{\operatorname{ch}}\left[\mathrm{I}_{2}\right]^{1 / 2}\left[\operatorname{RCrL}\left(\mathrm{H}_{2} \mathrm{O}\right)^{2+}\right]^{3 / 2}+k_{e l}\left[\mathrm{I}_{2}\right]\left[\operatorname{RCrL}\left(\mathrm{H}_{2} \mathrm{O}\right)^{2+*}\right]$

Where the first term represents the chain reaction and the second represents simple electrophilic substitution. Different $\mathrm{RCrL}\left(\mathrm{H}_{2} \mathrm{O}\right)^{2+}$ complexes react differently towards the same external reagent, $I_{2}$. When $R=2^{0}$-alkyl or aralkyl, chain reaction dominates; when $R=1^{0}$-alkyl, electrophilic substiturion dominates. $\mathrm{RCrL}_{(}\left(\mathrm{H}_{2} \mathrm{O}\right)^{3+}, \mathrm{I}_{2}^{-\cdot}$, and $\mathrm{R}$ are the 
chain carriers. It was found that in the electrophilic substitution reactions, only $I_{2}$, not $I_{3}{ }^{-}$, is reactive regardless of $\mathrm{I}^{-}$concentration and the fact that $I_{2}$ and $I_{3}^{-}$are inter-convertible $\left(I_{2}+I^{-}==I_{3}^{-}\right)$and have similar redox potentials.

The chain reaction proceeds as follows,

$$
\begin{array}{ll}
\text { Initiation } & \mathrm{RCrL}\left(\mathrm{H}_{2} \mathrm{O}\right)^{2+}+\mathrm{I}_{2} \rightarrow \mathrm{RCrL}\left(\mathrm{H}_{2} \mathrm{O}\right)^{3+}+\mathrm{I}_{2}^{-\cdot} \\
\text { Propagation } & \mathrm{RCrL}\left(\mathrm{H}_{2} \mathrm{O}\right)^{3+} \rightarrow \mathrm{R}+\mathrm{CrL}\left(\mathrm{H}_{2} \mathrm{O}\right)^{2+} \\
& \mathrm{R} \cdot+\mathrm{I}_{2}+\mathrm{I}^{-} \rightarrow \mathrm{RI}+\mathrm{I}_{2}^{-\cdot} \\
& \mathrm{I}_{2}^{-\cdot}+\mathrm{RCrL}\left(\mathrm{H}_{2} \mathrm{O}\right)^{2+} \rightarrow \mathrm{RCrL}\left(\mathrm{H}_{2} \mathrm{O}\right)^{3+}+2 \mathrm{I}^{-} \\
\text {termination } & 2 \mathrm{I}_{2}^{-\cdot} \rightarrow \mathrm{I}_{3}^{-}+\mathrm{I}^{-}
\end{array}
$$

The involvement of $R$. in the chain propagation step is confirmed by $\mathrm{O}_{2}$ and $\mathrm{Cu}^{2}+$ inhibition effect.

$$
\begin{aligned}
& \mathrm{R}+\mathrm{O}_{2} \rightarrow \mathrm{RO}_{2} \cdot \\
& 2 \mathrm{RO}_{2}+\rightarrow \mathrm{ROH}+\mathrm{RHO}+\mathrm{O}_{2} \\
& \mathrm{Cu}^{2+}+\mathrm{R} \cdot+\mathrm{H}_{2} \mathrm{O} \rightarrow \mathrm{Cu}^{+}+\mathrm{ROH}+\mathrm{H}^{+}
\end{aligned}
$$

Small amounts of $v_{2}$ or $\mathrm{Cu}^{2+}$ change the fractional-order kinetic profile (which appears when the chain mechanism dominates) back to a normal pseudo-first order profile and the fast chain reaction rate back to the slow electrophilic substitution rate. Involvement of $\mathrm{I}_{2}^{-}$in $\therefore$ chain propagation step is confirme: by $\mathrm{Fe}^{2+}$ inhibition effect,

$$
\mathrm{I}_{2}^{-\cdot}+\mathrm{Fe}^{2+} \rightarrow 2 \mathrm{I}^{-}+\mathrm{Fe}^{3+}
$$


The chain reaction scheme is also supported by kinetic profile analysis, product analysis and stoichiometric determinations. Various $\mathrm{RCrL}\left(\mathrm{H}_{2} \mathrm{O}\right)^{2+}$ $\left(\mathrm{R}=\mathrm{CH}_{3}, \mathrm{C}_{2} \mathrm{H}_{5}, 1-\mathrm{C}_{3} \mathrm{H}_{7}, 1-\mathrm{C}_{4} \mathrm{H}_{9}, 2-\mathrm{C}_{3} \mathrm{H}_{7}, 2-\mathrm{C}_{4} \mathrm{H}_{9}, 4-\mathrm{CH}_{3} \mathrm{C}_{6} \mathrm{H}_{4} \mathrm{CH}_{2}, \mathrm{C}_{6} \mathrm{H}_{5} \mathrm{CH}_{2}\right.$, $4-\mathrm{BrC}_{6} \mathrm{H}_{4} \mathrm{CH}_{2}$ ) were studied. $k_{c h}$ and $\mathrm{k}_{e l}$ were measured. The crystal structure of $\mathrm{BrC}_{6} \mathrm{H}_{4} \mathrm{CH}_{2} \mathrm{CrL}\left(\mathrm{H}_{2} \mathrm{O}\right)^{2+}$ was determined by $\mathrm{x}$-ray crystallography.

Part III: Reactivities of Organochromium Complexes toward Inorganic Radicals. A Pulse Radiolysis Study.

Reason to study: The reaction between $\operatorname{RCrL}\left(\mathrm{H}_{2} \mathrm{O}\right)^{2+}$ and $\mathrm{X}_{2}-$ is to be explored, and independent evidence of reaction ( 8 ) is to be sought.

Conclusion: Quick generation of reactive radical anions $x_{2}$ - was realized by pulse radiolysis and follow-up radical conversions.

$$
\begin{aligned}
& \mathrm{e}(\mathrm{aq})^{-}+\mathrm{N}_{2} \mathrm{O}+\mathrm{H}_{2} \mathrm{O} \rightarrow \mathrm{HO}+\mathrm{HO}^{-}+\mathrm{N}_{2} \\
& \mathrm{HO}+2 \mathrm{X}^{-} \rightarrow \mathrm{HO}^{-}+\mathrm{X}_{2}^{-}
\end{aligned}
$$

The kinetics of the reaction

$$
\mathrm{X}_{2}{ }^{-\cdot}+\mathrm{RCrL}\left(\mathrm{H}_{2} \mathrm{O}\right)^{2+} \rightarrow 2 \mathrm{X}^{-}+\mathrm{RCrL}\left(\mathrm{H}_{2} \mathrm{O}\right)^{3+}
$$

was studied spectrophotometrically with $\mathrm{R}=1-\mathrm{C}_{3} \mathrm{H}_{7}, 2-\mathrm{C}_{3} \mathrm{H}_{7}, 4-\mathrm{BrC}_{6} \mathrm{H}_{4} \mathrm{CH}_{2}$, $4-\mathrm{CH}_{3} \mathrm{C}_{6} \mathrm{H}_{4} \mathrm{CH}_{2}$, and $\mathrm{X}=\mathrm{I}, \mathrm{Br}, \mathrm{SCN}$. Reaction (16) proceeds very fast $\left(t_{1 / 2}\right.$ $\sim 10 \mu \mathrm{s}$ ) consistent with the role it plays in the chain reaction (eqs (5) to (9)). Kinetic analysis suggests the formation of a loosely bound 
precursor, $\left\{\mathrm{X}_{2}-\cdot, \mathrm{RCrL}\left(\mathrm{H}_{2} \mathrm{O}\right)^{2+}\right\}$, prior to the electron transfer step. The reactivity trend is also discussed.

Part IV: Electron Transfer Reactions of Organochromium (IV/III) Macrocyclic Complexes and oxidation Induced Homolysis.

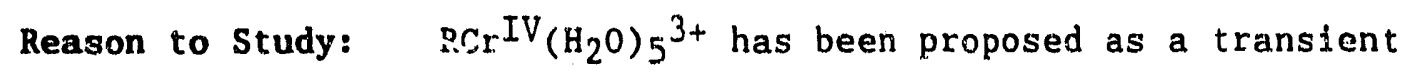
before, but not confirmed. Little is known about the organochromium (IV/III) redox potential and self-exchange rate presumably due to the short life-time of $\mathrm{RCr}(\mathrm{IV})$ species. It is important to find out the redox mechanism of these organochromium complexes and their redox potentials and self-exchange rates to establish guidelines for further reactivity investigations and applications.

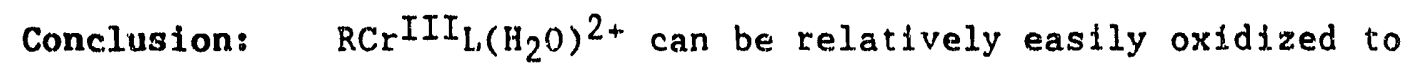

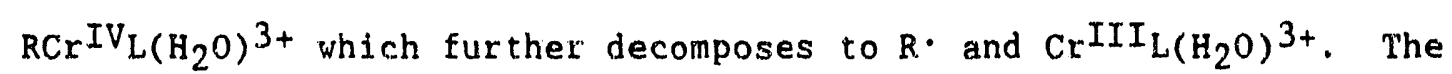
oxidation occurs via an outer-sphere electron transfer pathway. The outer-sphere electron transfer mechanism is also supported by the observed linear relationship predicted by Marcus' equation (with oxidants, ox $=\mathrm{IrCl}_{6}{ }^{2-}, \mathrm{Fe}^{3+}$, and $\mathrm{ABTS}^{-\cdot}$ ) and the reactivity trend of the oxidation of $\mathrm{RCrL}\left(\mathrm{H}_{2} \mathrm{O}\right)^{2+}$ by $\mathrm{IrCl}_{6}{ }^{2-}\left(\mathrm{R}=\mathrm{CH}_{3}, \mathrm{C}_{2} \mathrm{H}_{5}, 1-\mathrm{C}_{3} \mathrm{H}_{7}, 1-\mathrm{C}_{4} \mathrm{H}_{9}\right.$, $\left.2-\mathrm{C}_{3} \mathrm{H}_{7}, 2-\mathrm{C}_{4} \mathrm{H}_{9}, \quad 4-\mathrm{CH}_{3} \mathrm{C}_{6} \mathrm{H}_{4} \mathrm{CH}_{2}, \mathrm{C}_{6} \mathrm{H}_{5} \mathrm{CH}_{2}, 4-\mathrm{BrC}_{6} \mathrm{H}_{4} \mathrm{CH}_{2}\right) . \mathrm{k}_{1}$ values of all these $\mathrm{RCr}\left(\mathrm{H}_{2} \mathrm{O}\right)^{2+}$ were measured.

The reaction scheme is shown in eqs (17) to (19),

$$
\begin{array}{lr}
\mathrm{RCrL}\left(\mathrm{H}_{2} \mathrm{O}\right)^{2+}+\mathrm{ox} \rightarrow \mathrm{RCrL}\left(\mathrm{H}_{2} \mathrm{O}\right)^{3+}+\text { red } & \mathrm{k}_{1} \\
\mathrm{RCrL}\left(\mathrm{H}_{2} \mathrm{O}\right)^{3+} \rightarrow \mathrm{R} \cdot+\mathrm{CrL}\left(\mathrm{H}_{2} \mathrm{O}\right)^{3+} & \mathrm{k}_{2} \\
\mathrm{R} \cdot+\mathrm{ox} \longrightarrow \mathrm{P} & \text { fast }
\end{array}
$$


The nature of the product, $P$, depends on ox (e.g., $P=R C l$ when $o x=$ $\operatorname{IrCl}_{6}{ }^{2-} ; P=\mathrm{R}^{-\mathrm{ABTS}^{-}}$when $\left.\mathrm{OX}=\mathrm{ABTS} \cdot\right)$. Results of product analysis, stoichiometric determination, and kinetic study are consistent with the notion that homolysis is the major decomposition pathway of $\operatorname{RCrL}\left(\mathrm{H}_{2} \mathrm{O}\right)^{3+}$. The reactions were followed by stopped-flow and conventional kinetic methods. The products were analyzed by GC and UV-vis spectra.

For the first time we developed a simple kinetic method to estimate a redox potential of an unstable couple (like $\mathrm{RCr} I \mathrm{IV}_{\mathrm{L}}\left(\mathrm{H}_{2} \mathrm{O}\right)^{3+}$ / $\mathrm{RCrIII}\left(\mathrm{H}_{2} \mathrm{O}\right)^{2+}$ ) along with its self-exchange rate. This kinetic method complements the existing electrochemical techniques for potential measurement. It applies to redox couples containing an unstable species (generated by an electron transfer and destroyed by a follow up chemical reaction). Contrary to cases of traditional electrochemical measurements, the faster is the follow-up reaction, the more accurate is the estimation of the potential by the kinetic method. The self-exchange rate, $k_{11}$, can be calculated by Marcus' equation using the estimated $E^{\circ}$ value. Our estimated values (e.g., $\mathrm{E}^{\mathrm{O}}=0.76+0.13 \mathrm{~V}$ and $\mathrm{k}_{11}=4.2$ $\mathrm{M}^{-1} \mathrm{~S}^{-1}$ for $4-\mathrm{BrC}_{6} \mathrm{H}_{4} \mathrm{CH}_{2} \mathrm{CrL}\left(\mathrm{H}_{2} \mathrm{O}\right)^{3+} / 4-\mathrm{BrC}_{6} \mathrm{H}_{4} \mathrm{CH}_{2} \mathrm{CrL}\left(\mathrm{H}_{2} \mathrm{O}\right)^{2+}$ couple) are certainly within reasonable range.

The kinetic retardation effect of [red] $=\left[\right.$ ABTS $\left.^{2-}\right]$ confirms that a $\mathrm{RCrL}\left(\mathrm{H}_{2} \mathrm{O}\right)^{3+}$ has a finite life time. The estimated iife time is c.a. 1 ins.

Part V: Reduction Induced Cleavage of Cobalt-Carbon Bond in Organocobalt Kacrocyclic Complexes.

Reason to Study: The fate of reduced organocobalts is a center of many debates because of its biological importance and "contradictory" 
observations made in different laboratories, probably due to the lack of the knowledge about the shortly-lived reaction intermediates.

Conclusion: We demonstrated that both $1 \mathrm{e}$ and $2 \mathrm{e}$ reductions of $\mathrm{RCO}_{\mathrm{III}} \mathrm{L}$ can be achieved chemically and electrochemically to yield $\mathrm{RCo} \mathrm{II}_{\mathrm{L}} 1-$ and $\mathrm{RCo}_{\mathrm{L}} \mathrm{I}^{2-}$. For the first time we found that a-elimination is the major decomposition pathway of $1^{\circ}$ - and $2^{\circ}$-alkylcobalt(II) complexes, $\mathrm{RCO} \mathrm{II}_{L_{1}} 1-$. Hydrolysis of $\mathrm{RCo} I_{\mathrm{L}} 1-$, affording $\mathrm{RH}$ and $\mathrm{Co}_{\mathrm{I}} \mathrm{I}_{\mathrm{L}}$, becomes important only in the presence of water. The $\mathrm{R}(-\mathrm{H})$ and $\mathrm{RH}$ presented in the product mixture were actually produced directly from $\mathrm{RCo}^{I I_{L}}{ }^{1-}$ by separate pathways, rather than from disproportionation of $R$. (generated by homolysis, $\mathrm{RCo} \mathrm{II}_{\mathrm{L}} 1-\rightarrow \mathrm{R} \cdot+\mathrm{Co}_{\mathrm{L}} \mathrm{I}^{1-}$ ) as suspected in literature. The explanation of the generation of oxidized product $R(-H)$ from reduced organochromium, $\mathrm{RCO}(\mathrm{II}) \mathrm{L}^{1-}$, involves participation of equatorial ligand $\mathrm{L}$ to yield $\mathrm{LH}$. We also discovered that when $\beta-H$ is absent in $R$, the $R$ group migration from cobalt to the equatorial ligand $L$ becomes an important reaction pathway. $\mathrm{RH}$ is the major decomposition product of $\mathrm{RCo}_{\mathrm{L}^{2}}{ }^{2}$. The general reaction scheme is shown below,

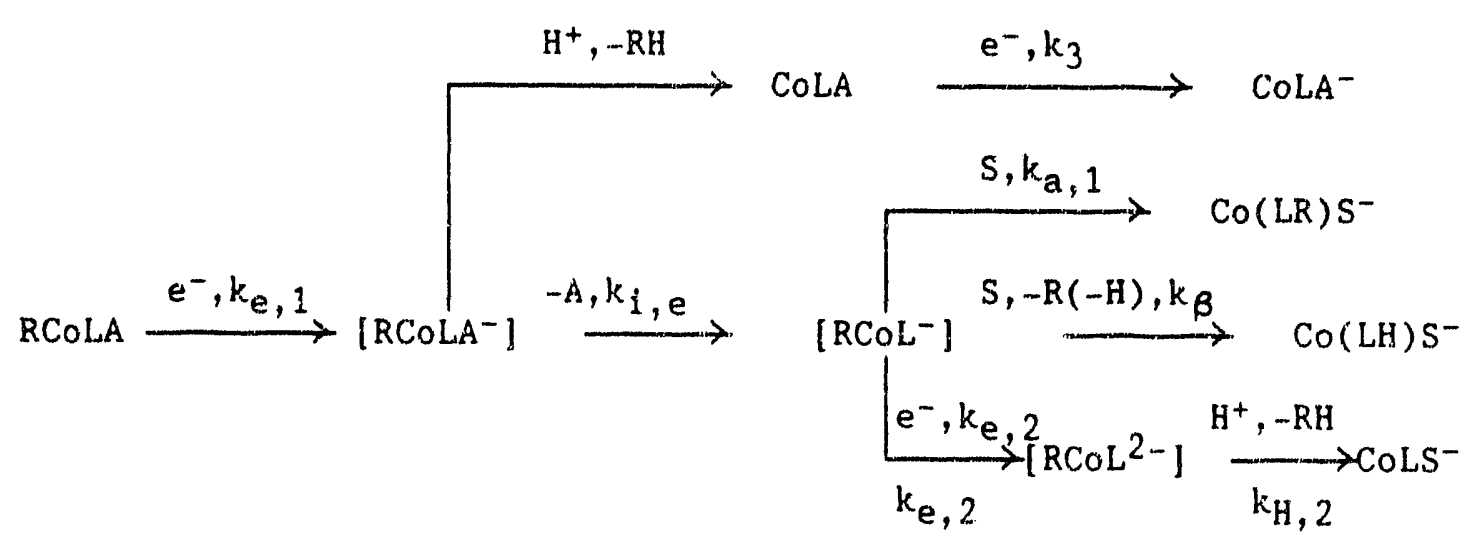

where $\mathrm{R}=\mathrm{CH}_{3}, \mathrm{C}_{2} \mathrm{H}_{5}, 1-\mathrm{C}_{3} \mathrm{H}_{7}, 2-\mathrm{C}_{3} \mathrm{H}_{7}, 4-\mathrm{CH}_{3} \mathrm{C}_{6} \mathrm{H}_{4} \mathrm{CH}_{2}, \mathrm{C}_{6} \mathrm{H}_{5} \mathrm{CH}_{2}, 4-\mathrm{BrC}_{6} \mathrm{H}_{4} \mathrm{CH}_{2}$; $L=(d m g B F 2)_{2}$; and with trans group $A, A=\mathrm{H}_{2} \mathrm{O}, \mathrm{OH}^{-}$, and py. The 
starting complexes, RCoIII $I_{L}$, were prepared by nucleophilic substitution between $\mathrm{Co}_{\mathrm{L}^{-}}$and $\mathrm{RX}$. Rate constants, $k_{e, 1}$ and $k_{e, 2}$, of these complexes were measured by using $\mathrm{Ni}^{I}(\mathrm{tmc})^{+}$as the reductant. The reactivity trend agrees with the above scheme.

The reductions were studied both electrochemically and chemically. The reduction intermediate and products were detected by ESR, fast mixing and fast scan techniques, GC, UV-Vis, NMR, and electrochemical methods. The proposed reaction scheme was based on results from intermediate trapping, change of product distribution with conditions, as well as kinetic profiles, rates and reactivity trend. $\mathrm{RCo} \mathrm{I}_{\mathrm{L}} 1-$ with $(t)^{6}\left(d_{x^{2}}-y^{2}\right)^{1}$ configuration provides the first example of $g>g$ in $d^{7}$ cobalt(II) complexes, implying a flattened pseudo-Oh ligand field. This configuration explains the fact that homolysis does not occur immediately at the $\mathrm{RCO} I I_{\mathrm{L}} 1$ - stage (the odd electron is not in the Co-C antibonding orbital) and instead the internal electron transfer occurs yielding RCoII ${ }^{\prime} 1$ - which assists the follow-up Belimination.

Part VI: Molecular Structure of a Cobalt(I) Complex Lacking a Carbonyl Ligand. An Unique Example of $\mathrm{C}-\mathrm{N}$ Bond Shortening upon Reduction. Reason to Study: Synthesis and structural determination of cobalt(I) macrocyclic complexes have been challenges to chemists who want to study reactions catalyzed by vitamin $B_{12}$ coenzymes. Efforts along this direction were often frustrated by the extreme instability of the cobalt(I) macrocycles. Only a few attempts were fruitful by letting electron withdrawing Co ligand coordinate to cobalt. But carbonyl obalt macrocycles are not relavent to vitamin $B_{12}$ systems. 
Conclusion: Successful synthesis and crystallization of a cobalt(I) macrocyclic complex was accomplished by an electrolysis induced hydrolysis of an alkylcobalt(III) complex. The molecular structure of the novel cobalt(I) macrocyclic complex $\mathrm{Co}^{\mathrm{I}}\left(\mathrm{dmgBF}_{2}\right)_{2} \mathrm{py}^{-}$is characterized by $x$-ray diffraction. The diamagnetism of the complex as reflected by ESR silence and well defined ${ }^{1}$ H-NMR spectrum strongly supports the assignment of the low spin $d^{8}$ electron configuration $(t)^{6}\left(d_{z} 2\right)^{2}$ to the complex.

A rather unexpected shortening of the Co-N (of the equatorial ligand) bonds upon reduction (as compared to those of $\mathrm{Co}^{\mathrm{II}}(\mathrm{dmgBF})_{2}$ ) was discovered with this complex. This discovery challenges the commonly accepted thinking: an atomic (or ionic) radius increases as the atom (or ion) is reduced, so does the bond distance related to the atom (or ion). We explain this unusual shortening upon reduction in light of orbital interaction (between $\operatorname{Co}\left(\mathrm{d}_{z} 2\right)$ and $\left(\mathrm{dmgBF}_{2}\right)_{2}\left(\pi^{\star}\right)$ ), which changes from symmetry forbidden to symmetry allowed. The change of the orbital interaction is also evidenced by the changes of the bond distances within the equatorial ligand. 
PART I. ORGANOCHROMIUM(III) MACROCYCLIC COMPLEXES. PACTORS CONTROLLIMG BOHOLYTIC VS. HETEROLTTIC CLEAVAGE OF THE CHROMIUM-CARBON BOND 


\section{INTRODUCTION}

Conventional ligand substitution reactions of inorganic and orgarometallic complexes are two-electron processes. They are relatively well understood in terms of the electronic and structural factors that control the rate. ${ }^{1-3}$ In contrast, much less is known about the factors controlling the rates of unimolecular bond homolysis reactions, $L_{5} M^{n}-R \rightarrow$ $\mathrm{L}_{5} \mathrm{M}^{\mathrm{n}-1}+\mathrm{R} \cdot(\mathrm{R}=$ alkyl, aralkyl). The data avallable for complexes such as $\left(\mathrm{H}_{2} \mathrm{O}\right){ }_{5} \mathrm{CrR}^{2}+4,5$ and macrocyclic organocobalt complexes ${ }^{6}$ suggest that both steric and electronic factors must be considered.

We consider here a family of organochromium(III) macrocycles, $\operatorname{RCrL}\left(\mathrm{H}_{2} \mathrm{O}\right)^{2+}\left(\mathrm{L}=[15] \operatorname{aneN}_{4}=1,4,8,12\right.$-tetraazacyclopentadecane $)$ in aqueous solution. With a trans ligand $A\left(A=\mathrm{H}_{2} \mathrm{O}\right.$ and $\left.\mathrm{OH}^{-}\right)$, we consider the possibilities of homolysis (eq I-1) and heterolysis (eq I-2). Neither reaction type has been examined previously for these complexes.

$$
\begin{gathered}
\mathrm{RCr}^{\mathrm{III}} \mathrm{L(A)}{ }^{\mathrm{n}+} \longrightarrow \mathrm{Cr}^{\mathrm{II}} \mathrm{L}(\mathrm{A})^{\mathrm{n}+}+\mathrm{R} \cdot \\
\mathrm{RCr}^{\mathrm{III}} \mathrm{L}(\mathrm{A})^{\mathrm{n}+}+\mathrm{H}_{2} \mathrm{O} \longrightarrow \mathrm{HOCr}^{\mathrm{III}} \mathrm{L}(\mathrm{A})^{\mathrm{n}+}+\mathrm{RH}
\end{gathered}
$$

The presence of the macrocyclic ligand offers certain advantapes in studying the reactivity of the metal-carbon bond. Most significantly, the macrocycle permits variation of the $\mathrm{pH}$ over a wide range, in contrast to the complexes $\left(\mathrm{H}_{2} \mathrm{O}\right)_{5} \mathrm{CrR}^{2+}$ that rapidly decompose above $\mathrm{pH} \sim 4$. This allows examination of the species with $\mathrm{A}=\mathrm{OH}^{-}$. In this article we present data showing that variation of $\mathrm{A}$ changes the mechanism of the $\mathrm{Cr}-$ 
$\mathrm{C}$ bond cleavage from homolytic to heterolytic. We explain this finding by the stabilizing effect of the strongly electron-donating $\mathrm{OH}^{-}$group on the $3+$ oxidation state of chromium. The same phenomenon helps in the understanding of the reactivity order when the $R$ group is changed. 
EXPERIMENTAL SECTION

Materials. The complexes $\operatorname{RCrL}\left(\mathrm{H}_{2} \mathrm{O}\right)^{2+}$ were prepared by the known reaction of $\mathrm{REr}$ or $\mathrm{RI}$ with $\left(\mathrm{H}_{2} \mathrm{O}\right)_{2} \mathrm{CrL}^{2+}$, and separated by ion exchange chromatography on Sephadex C25.7 The electronic spectra matched the reported values. ${ }^{7}$ Radical scavengers were $\left[\mathrm{Co}\left(\mathrm{NH}_{3}\right)_{5} \mathrm{Br}\right]\left(\mathrm{ClO}_{4}\right)_{2} 8$ and HTMPO $^{9}$ (Aldrich). The ESR and UV-Visible spectrum of HTMPO matched the Iiterature values. 10

Techniques, ESR spectra were recorded on aqueous solutions with an IBM-Bruker ER-200 spectrometer. Since the activation energies of metalalkyl homolysis are in general rather large, 4-6 homolysis can be promoted at elevated temperature. This approach was used to conduct the ESR study. Samples of the complex $\operatorname{RCrL}(A)^{\mathrm{n}+}$ in the preserce of a three-fold excess of HTMPO were immersed in a water bath at $40^{\circ} \mathrm{C}$ to initiate decomposition. At a fixed time, decomposition was quenched by immersing the sample in an ice-water bath. The sample was then warmed back to 15 ${ }^{\circ} \mathrm{C}$ and the ESR spectrum recorded. With bath temperature and timing controlled, the method was reproducible.

Organic products were identified with a Hewlett-Packard Model 5790 gas chromatograph, with a 6' $6^{\prime} 1 / 8^{\prime \prime}$ column packed with 0V-101 or VZ-10. The gas chromatograph was calibrated with standard organic halides and hydrocarbons. Electronic spectra were recorded with a Perkin-Elmer Lambda Array 3840 diode array spectrophotometer. 
Rinetic Measurements. The homolytic decomposition of the organochromium macrocycles $\mathrm{RCrL}\left(\mathrm{H}_{2} \mathrm{O}\right)^{2+}$ was monitored spectrophotometrically at their absorption maxima: $\lambda 287$ and $400 \mathrm{~nm}$ for $\mathrm{R}=1-\mathrm{Pr}, 359 \mathrm{~nm}$ for $\mathrm{p}-\mathrm{CH}_{3} \mathrm{C}_{6} \mathrm{H}_{4} \mathrm{CH}_{2}, 353 \mathrm{~nm}$ for $\mathrm{C}_{6} \mathrm{H}_{5} \mathrm{CH}_{2}$, and $360 \mathrm{~nm}$ for $\mathrm{p}-$ $\mathrm{BrC}_{6} \mathrm{H}_{4} \mathrm{CH}_{2}$. These measurements were carried out in an argon atmosphere on solutions containing $0.010 \mathrm{M} \mathrm{HClO}_{4}$ and $0.20 \mathrm{M} \mathrm{NaClO}_{4}$. The heterolytic decomposition in basic solutions was monitored at $274 \mathrm{~nm}(\mathrm{R}=i-\mathrm{Pr})$ and $260 \mathrm{~nm}(\mathrm{n}-\mathrm{Pr})$ at $\left[\mathrm{OH}^{-}\right]=7.2-160 \mathrm{mM}, \mu=0.20 \mathrm{M}$. Some experiments, including the temperature dependence, were done at $\left[\mathrm{OH}^{-}\right]=\mu=0.82 \mathrm{M}$. In every case temperature was precisely controlled by immersing the quartz cluvette in a water bath positioned in the light beam of the spectrophotometer; thermostated water was circulated through the jacket of the water bath. Organochromium macrocycles were used as limiting reagents in both homolysis and heterolysis studies. The kinetic data were obtained by means of a Cary Model 14 spectrophotometer that had been converted to a computer-controlled instrument by on Line Instrument Systems. The OLIS data station also provided the least squares program for the analysis of the absorbance-time data according to the first-order equation $A_{t}=A_{\infty}+\left(A_{0}-A_{\infty}\right) e^{-k t}$. 


\section{RESULTS}

Bond Bosolysis. Unimolecular homolysis of the chromium-carbon bond was observed for secondary alkyl and aralkyl chromium complexes $\operatorname{RCrL}\left(\mathrm{H}_{2} \mathrm{O}\right)^{2+}$ in slightly acidic $\left(\left[\mathrm{H}^{+}\right]=1.0 \times 10^{-2} \mathrm{M}\right)$ solutions in the presence of free radical scavengers. For example, some experiments were conducted in the presence of the persistent free radical HTMPO, 9 which is known ${ }^{11}$ to capture in situ gener,ted free radicals, eq I-3. We found that HTMPO also reacts rapidly with $\left(\mathrm{H}_{2} \mathrm{O}\right)_{2} \mathrm{CrL}^{2+}$, eq $\mathrm{I}-4$. The ESR technique was employed in this study to estimate the rate of homolysis. The intensity of the ESR signal of HTHPO decreased as the homolysis of the 1-propylchromium complex proceeded, Figure I-1.

$$
\begin{gathered}
\mathrm{R} \cdot+\mathrm{HTMPO} \longrightarrow \mathrm{R}-\mathrm{HTMPO} \\
\left(\mathrm{H}_{2} \mathrm{O}\right)_{2} \mathrm{CrL}^{2+}+\mathrm{HTMPO} \longrightarrow\left(\mathrm{H}_{2} \mathrm{O}_{2} \mathrm{CrL}^{3+}+\mathrm{HTMPO}^{-}\right.
\end{gathered}
$$

Another scavenger is $\left(\mathrm{NH}_{3}\right)_{5} \mathrm{CoBr}^{2+}$, which reacts with free radicals 12 (eq I-5) and with the chromium(II) macrocycle ${ }^{13}$ (eq I-6). Because of their dual functions both HTMPO and $\left(\mathrm{NH}_{3}\right)_{5} \mathrm{CoBr}{ }^{2+}$ are effective scavengers in this system.

$$
\begin{gathered}
\left(\mathrm{NH}_{3}\right)_{5} \mathrm{CoBr}^{2+}+\mathrm{R} \cdot \stackrel{\mathrm{H}_{3} \mathrm{O}^{+}}{\longrightarrow} \mathrm{RBr}+\mathrm{Co}_{\mathrm{aq}}{ }^{2+}+5 \mathrm{NH}_{4}^{+} \\
\left(\mathrm{NH}_{3}\right)_{5} \mathrm{CoBr}^{2+}+\left(\mathrm { H } _ { 2 } \mathrm { O } _ { 2 } \mathrm { CrL } ^ { 2 + } \stackrel { \mathrm { H } _ { 3 } \mathrm { O } ^ { + } } { \longrightarrow } \mathrm { BrCrL } \left(\mathrm{H}_{2} \mathrm{O}^{2+}+\mathrm{Co}_{\mathrm{aq}}{ }^{2+}+5 \mathrm{NH}_{4}^{+}\right.\right.
\end{gathered}
$$


The analysis of organic products by GC confirmed that homolysis is the only reactivity mode in acidic solutions for all the complexes examined. For example, the reaction of $(2-\mathrm{Pr}) \mathrm{Cr}\left([15] \mathrm{aneN}_{4}\right)^{2+}$ in the presence of $\left(\mathrm{NH}_{3}\right)_{5} \mathrm{COBr}{ }^{2}+$ yielded $2-\mathrm{PrBr}$ as the exclusive organic product, consistent with the sequence of reactions $I-1$ and $I-5.12$ No propane was detected, which effectively rules out any heterolysis under these conditions.

Quantitative kinetic studies of the homolysis were conducted spectrophotometrically in the presence of either HTMPO or $\left(\mathrm{NH}_{3}\right)_{5} \mathrm{CoBr}{ }^{2+}$. The reactions (eq I-7) are first-order with respect to the concentration of the organochromiun macrocycle and zero order with respect to the scavenger concentration (eq I-8). The concentration conditions and rate constants are summarized in Table I-1.

$$
\begin{gathered}
\operatorname{RCrL}\left(\mathrm{H}_{2} \mathrm{O}\right)^{2+} \stackrel{\mathrm{H}_{2} \mathrm{O}}{\longrightarrow} \mathrm{R} \cdot+\mathrm{CrL}\left(\mathrm{H}_{2} \mathrm{O}\right)_{2}^{2+} \\
-\mathrm{d}\left[\mathrm{RCrL}\left(\mathrm{H}_{2} \mathrm{O}\right)^{2+}\right] / d t=k_{7}\left[\operatorname{RCrL}\left(\mathrm{H}_{2} \mathrm{O}\right)^{2+}\right]
\end{gathered}
$$

No homolytic cleavage of the $\mathrm{Cr}-\mathrm{C}$ bond was observed for $\mathrm{RCrL}\left(\mathrm{H}_{2} \mathrm{O}\right)^{2+}$ when $R$ was a primary alkyl group, as tested for $R=C_{2} H_{5}, n-C_{3} H_{7}$, and $n-$ $\mathrm{C}_{4} \mathrm{Hg}$. Indeed, in the absence of a scavenger even the secondary alkyl and aralkyl complexes do not undergo net homolysis because the reverse of reaction I-7 occurs rapidly. Thus these organochromium macrocycles can be stored for weeks when kept in a refrigerator under nitrogen or argon. 
Trans Effects on Homolysis of the Hydroxo Complexes. A change of $\mathrm{pH}$ from 4 to 6 of a solution of $\mathrm{RCrL}\left(\mathrm{H}_{2} \mathrm{O}\right)^{2+}$ causes an instantaneous color change from yellow to red. The associated spectral changes are shown in Figure I-2. When the solution is re-acidified, the yellow color is restored and the spectrum of $\mathrm{RCrL}\left(\mathrm{H}_{2} \mathrm{O}\right)^{2+}$ reappears. The reversibility of the spectral changes indicates that the chromium-carbon bond remains intact; reversible deprotonation of the rans water molecule yields $\mathrm{RCrL}(\mathrm{OH})+.14,15$

The progress of the homolysis was monitored by the ESR signal of the scavenger HTMPO. As shown in Figure I-1A, the in ensity of the ESR spectrum of HTMPO in the presence of $\mathrm{i}-\mathrm{C}_{3} \mathrm{H}_{7} \mathrm{CrL}(\mathrm{OH})^{+}$remains virtually unchanged after $15 \mathrm{~min}$ at $40^{\circ} \mathrm{C}$. In contrast, the decreasing ESR signal, Figure I-1B, shows a significant loss of HTMPO during the homolysis of 1$\mathrm{C}_{3} \mathrm{H}_{7} \mathrm{CrL}\left(\mathrm{H}_{2} \mathrm{O}\right)^{2+}$ in $-12 \mathrm{~min}$ at $40^{\circ} \mathrm{C}$. This establishes that the homolysis rate of the hydroxo complex is negligibly sinall compared to that of the aqua complex.

Temperature Dependence of Bcwolysis Rate Constants. The value of $k 7$ was determined over a range of temperatures for each of the complexes $\operatorname{RCrL}\left(\mathrm{H}_{2} \mathrm{O}\right)^{2+}$ with either $\left(\mathrm{NH}_{3}\right)_{5} \mathrm{CoBr}{ }^{2+}$ or HTMPO used to draw the reaction to completion. The groups $\mathrm{R}$ and the temperature range for each are: $i-\mathrm{C}_{3} \mathrm{H}_{7}$, 286-333 K; $\mathrm{p}-\mathrm{CH}_{3} \mathrm{C}_{6} \mathrm{H}_{4} \mathrm{CH}_{2}, 295-332 \mathrm{~K} ; \mathrm{C}_{6} \mathrm{H}_{5} \mathrm{CH}_{2}, 298-333 \mathrm{~K} ; \mathrm{p}-\mathrm{BrC}_{6} \mathrm{H}_{4} \mathrm{CH}_{2}$, 298-344 K, as shown in Figure I-3. The values of $\Delta H^{\neq}$and $\Delta S^{\ddagger}$ were determined from a fit of the data to the Eyring equation, to which they nicely conformed. The values of $\Delta H^{\neq} \neq$and $\Delta S \neq$ are summarized in Table I-2. 
Heterolytic Cleavage of the $\mathrm{Cr}-\mathrm{C}$ Bond. Although the trans aqua organochromiun macrocyclic cations do not undergo acidolysis in acidic solutions (at least not in comparison with the dominant homolysis reaction), the situation is different for the hydroxo complexes $\mathrm{RCrL}(\mathrm{OH})^{+}$ at $\mathrm{pH}$ 12-14. Here, the complexes with $\mathrm{R}=\mathrm{i}-\mathrm{C}_{3} \mathrm{H}_{7}$ and $\mathrm{n}-\mathrm{C}_{3} \mathrm{H}_{7}$ both undergo slow hydrolysis, eq I-9, to yield propane as the only organic product detected gas chromatographically. Both the kinetics and the organic products are unaffected by the presence of HTMPO and $\left(\mathrm{NH}_{3}\right)_{5} \mathrm{COBr}^{2+}$. This clearly rules out any contribution from a homolytic pathway. The nature of the chromium produrt in eq I-9 was assuned but not verified. No decomposition of the aralkyl chromium complexes was observed in basic solutions.

$$
\mathrm{RCrL}(\mathrm{OH})^{+}+\mathrm{H}_{2} \mathrm{O} \longrightarrow \mathrm{RH}+\mathrm{CrL}(\mathrm{OH})_{2}^{+}
$$

The rate of reaction I-9 follows first-order kinetics, with $\mathrm{kg}=$ $(2.3 \pm 0.2) \times 10^{-4} s^{-1}$ for $R=1-C_{3} H_{7}$, and $(6.6 \pm 0.3) \times 10^{-5} s^{-1}$ for $R=$ $\mathrm{n}-\mathrm{C}_{3} \mathrm{H}_{7}$ at $25^{\circ} \mathrm{C}$. The values of $\mathrm{k} \cdot 9$ are independent of $\left[\mathrm{OH}^{-}\right]$in the range $7.2-160 \mathrm{mM}$ at $\mu=0.20 \mathrm{M}$ and in the range $0.16-1.0 \mathrm{M}$ at nonconstant ionic strength. The variation of temperature $(298-338 \mathrm{~K})$ gave the activation parameters: $\Delta H^{\ddagger}=78 \pm 1 \mathrm{~kJ} \mathrm{~mol}^{-1}, \Delta S^{\ddagger}=-53 \pm 2 \mathrm{~J} \mathrm{~mol}^{-1} \mathrm{~K}^{-1}$ for $\mathrm{R}=\mathrm{i}-\mathrm{C}_{3} \mathrm{H}_{7}$, and $\Delta \mathrm{H}^{\neq}=83 \pm 3 \mathrm{~kJ} \mathrm{~mol}^{-1}, \Delta \mathrm{S}^{\prime}=-46 \pm 9 \mathrm{~J} \mathrm{~mol}^{-1} \mathrm{~K}^{-1}$ for $\mathrm{R}=\mathrm{n}-\mathrm{C}_{3} \mathrm{H}_{7}$ as shown in Table I-2. The rate constant for $\mathrm{n}-\mathrm{C}_{3} \mathrm{H} 7 \mathrm{CrL}(\mathrm{OD})^{+}$ in $D_{2} O$ was also measured, with $k_{9}=6.2 \times 10^{-5} \mathrm{~s}^{-1}$ at $25.0^{\circ} \mathrm{C}$. 


\section{DISCUSSION}

The instantaneous and reversible optical change, Figure I-2, in the $\mathrm{pH}$ range 4-6 has been assigned to the conversion of $\mathrm{RCrL}\left(\mathrm{H}_{2} \mathrm{O}\right)^{2+}$ to $\mathrm{RCrL}(\mathrm{OH})^{+}$. The lowest energy charge transfer $(\mathrm{R} \rightarrow \mathrm{Cr})$ band shifts to higher energy in basic solution, consistent with the $\pi$-donor ability of $\mathrm{OH}^{-}$which increases the energy of the " $\mathrm{t}_{2} \mathrm{~g}$ " orbitals resulting in a higher energy for the $R \rightarrow C r$ charge transfer transition. Put differently, $\mathrm{RCrL}(\mathrm{OH})^{+}$is a weaker oxidant than $\operatorname{RCrL}\left(\mathrm{H}_{2} \mathrm{O}\right)^{2+}$.

The existence of both aqua and hydroxo complexes allows the study of the homolysis of both species. For the secondary alkyl and aralkyl aqua complexes the reaction is indeed homolysis baseci on the following evidence: (a) the reaction proceeds in the presence of scavengers for. both $\mathrm{R}$. and $\left(\mathrm{H}_{2} \mathrm{O}\right){ }_{2} \mathrm{CrL}^{2+}$; (b) the rate constant remains independent of the scavenger concentration; (c) the rate constant is independent of which scavenger was used, but varies with the group $R$. The primary alkyl complexes do not undergo homolysis even over very long times. This is consistent with the lower thermodynamic stability of primary alkyl radicals as compared to secondary and aralkyl radicals.

Under the same concentration and temperature conditions none of the hydroxo complexes, $\mathrm{RCrL}(\mathrm{OH})^{+}$, undergoes homolysis. This is again related to the electron donating effect of $\mathrm{OH}^{-}$, which stabilizes the $\mathrm{Cr}$ (III) state and thus makes it less susceptible to internal electron transfer that accompanies homolysis of eq I-7.

The activation parameters for bond homolysis are listed in 
Table I-2. The large values of $\Delta H \neq$ reflect the large chromium-carbon bond strengths of these complexes. Indeed, they can be taken as an approximate measure of the bond dissociation enthalpy, once allowance is made for the relatively small value of $\Delta \|_{-} \neq$for the radical recombination reaction. 6,16 The value of $\Delta \mathrm{H}^{\neq}$for $\left(\mathrm{H}_{2} \mathrm{O}\right)_{5} \mathrm{CrCH}_{2} \mathrm{Ph}^{2+}(133 \mathrm{~kJ}$ $\mathrm{mol}^{-1}$ ) is significantly larger than the value of $103 \mathrm{~kJ} \mathrm{~mol}^{-1}$ for 1 ts macrocyclic analogue. This difference in $\Delta H^{\ddagger}$ can be explained on the basis of the molecular structures, in particular the longer $\mathrm{Cr}-\mathrm{C}$ bond in the macrocycle. 17 The compound $\left[\mathrm{p}-\mathrm{BrC}_{6} \mathrm{H}_{4} \mathrm{CH}_{2} \mathrm{CrL}\left(\mathrm{H}_{2} \mathrm{O}\right)\right]\left(\mathrm{ClO}_{4}\right)_{2} \cdot \mathrm{THF}$ has a $\mathrm{Cr}-\mathrm{C}$ bond length of $2.14 \AA, 17$ noticeably longer than the $2.06 \AA$ distance in trans $-\left[\mathrm{CH}_{2} \mathrm{ClCr}(\mathrm{acac})_{2} \mathrm{H}_{2} \mathrm{O}\right] .18$ No complex in the $\left[\left(\mathrm{H}_{2} \mathrm{O}\right)_{5} \mathrm{CrR}\right] \mathrm{X}_{2}$ series has been crystallized, although one anticipates a $\mathrm{Cr}-\mathrm{C}$ bond as short or shorter than that in the acac derivative. This argtment is, however, somewhat speculative, since the overall charge is different in the pentaaqua and acac series.

The observed effect of the macrocycle on the $\mathrm{Cr}-\mathrm{C}$ bond strength is the net result of two opposing effects, steric and electronic. The former weakens and lengthens the bond. The electron donation from the $\mathrm{N}_{4}$ macrocycle, on the other hand, stabilizes the $\operatorname{Cr}$ (III) state, and thus inhibits homolysis. The size of the electronic effect of [15]aneN 4 becomes obvious if one compares the reduction potentials for the couples $\mathrm{Cr}\left(\left[15\right.\right.$ ]aneN $\left._{4}\right)\left(\mathrm{H}_{2} \mathrm{O}\right) 2^{3+/ 2+}(-0.58 \mathrm{~V})^{7}$ and $\mathrm{Cr}\left(\mathrm{H}_{2} \mathrm{O}\right) 6^{3+/ 2+}(-0.41 \mathrm{~V})$. Yet despite the electronic effect favoring the $\operatorname{Cr}($ III) state, the $\mathrm{Cr}-\mathrm{C}$ bond is weaker in the macrocyclic series. This point illustrates just how dominant steric effects are on bond strengths, a point made already in earlier work. 19,20 
Despite the lowering of $\Delta H^{\neq}$for the macrocycle, the homolysis of $\left(\mathrm{H}_{2} \mathrm{O}\right)_{5} \mathrm{CrCH}_{2} \mathrm{Ph}^{2+}\left(\mathrm{k}=2.6 \times 10^{-3} \mathrm{~s}^{-1}\right)^{5}$ proceeds more rapldly than that of the analogous $\mathrm{PhCH}_{2} \mathrm{CrL}\left(\mathrm{H}_{2} \mathrm{O}\right)^{2+}\left(1.2 \times 10^{-4} \mathrm{~s}^{-1}\right)$. This, of course, is due to the more-than-offsetting values of $\Delta S \neq$. The complex $\left(\mathrm{H}_{2} \mathrm{O}\right)_{5} \mathrm{CrCH}_{2} \mathrm{Ph}^{2+}$ has a $\Delta S^{\prime} \neq$ value of $153 \mathrm{~J} \mathrm{~mol}^{-1} \mathrm{~K}^{-1}$, as compared to $28 \mathrm{~J} \mathrm{~mol}^{-1} \mathrm{~K}^{-1}$ for $\left(\mathrm{H}_{2} \mathrm{O}\right) \mathrm{Cr}(\mathrm{L}) \mathrm{CH}_{2} \mathrm{Ph}^{2+}$. This large difference seems to indicate that the second coordination sphere "loosens up" much more in reaching the transition state in the aqua series. This is not unreasonable given that $\left(\mathrm{H}_{2} \mathrm{O}\right)_{5} \mathrm{CrR}^{2}+$ must be much more strongly solvated than the macrocyclic analogues and that in reaching the transition state for homolysis tine bond distances approach those for $\operatorname{Cr}$ (II) complexes. This means that the $\mathrm{Cr}-\mathrm{O}$ distances in $\left[\left(\mathrm{H}_{2} \mathrm{O}\right)_{5} \mathrm{Cr}---\mathrm{R}^{2+}\right]^{\neq}$stretch significantly, whereas the $\mathrm{Cr}-\mathrm{N}$ bond lengths in $\left[\left([15]_{a n e N_{4}}\right)\left(\mathrm{H}_{2} \mathrm{O}\right) \mathrm{Cr}-\cdots \mathrm{R}^{2+}\right]^{\neq}$remain virtually the same. Thus the effect on the second coordination sphere must be gi!te dramatic for $\left(\mathrm{H}_{2} \mathrm{O}\right)_{5} \mathrm{Cr}^{2+}$, but regligible in the macrocyclic series. In addition, there is a contribution from the rotational entropy changes of the coordinated molecules of water in $\left(\mathrm{H}_{2} \mathrm{O}\right)_{5} \mathrm{CrR}^{2+}$, a gain that has no counterpart in the macrocyclic series.

The rate constants for homolysis of $\mathrm{ArCH}_{2} \mathrm{CrL}\left(\mathrm{H}_{2} \mathrm{O}\right)^{2+}$ vary little as the substituent on the benzene ring changes from $\mathrm{p}-\mathrm{CH}_{3}$ to $\mathrm{H}$ to $\mathrm{p} \cdots \mathrm{Br}$. This is different from the behavior of the corresponding pentaaqua series, $\mathrm{p}-\mathrm{X}-\mathrm{C}_{6} \mathrm{H}_{4} \mathrm{CH}_{2} \mathrm{Cr}\left(\mathrm{H}_{2} \mathrm{O}\right)_{5}{ }^{2+}$, where the Hammett correlation yields the reaction constant $\rho=-1.01 .5$ The greater sensitivity to substituents in the pentaaqua complexes is qualitatively consistent with the $\mathrm{Cr}-\mathrm{C}$ bond being stronger for them. A greater degree of charge transfer in the 
transition state is required for homolysis of $\left(\mathrm{H}_{2} \mathrm{O}\right)_{5} \mathrm{CrCH}_{2} \mathrm{Ar}^{2+}$ as compared to $\mathrm{ArCH}_{2} \mathrm{Cr}(\mathrm{L}) \mathrm{H}_{2} \mathrm{O}^{2+}$.

Turning to the pathway for the heterolytic solvolysis rea tion, we note that $\mathrm{RCrL}(\mathrm{OH})^{+}$is not attacked by external $\mathrm{OH}^{-}$; $i . e$. , the rate is independent of $\left[\mathrm{OH}^{-}\right]$. This compares with the behavior of $\left(\mathrm{H}_{2} \mathrm{O}\right)_{5} \mathrm{CrR}^{2+}$ complexes, where inverse $\left[\mathrm{H}^{+}\right]$terms signal a conjugate base pathway that is significant enough to provide the major decomposition route at pH 4-7.21,22 With the macrocycles we find that only the hydroxo complexes, but not the aqua, are subject to heterolytic decomposition. It is significant that a reaction of the aqua complex with $\mathrm{H}_{3} \mathrm{O}^{+}$is not important. Even though $\mathrm{H}_{3} \mathrm{O}^{+}$ itself might function as an electrophile, there is no kinetically significant term with a direct dependence on $\left.\mathrm{I}_{3} \mathrm{O}^{+}\right]$, unliie the pentaaqua series where a term $k_{A}\left[\left(\mathrm{H}_{2} \mathrm{O}\right){ }_{5} \mathrm{CrR}^{2+}\right]\left[\mathrm{H}_{3} \mathrm{O}^{+}\right]$provides, for most $\mathrm{R}$ groups, a major pathway. ${ }^{4}$ This means that proton transfer to an incipient carbanion is not important for chromium-carbon bond heterolysis of $\mathrm{RCrL}(\mathrm{OH})^{+}$ complexes.

How is the rate law, which has the form $\left.\mathrm{kglRCrL}(\mathrm{OH})^{+}\right]$, to be interpreted? One can hardly attribute it to a path in which an external $\mathrm{H}_{2} \mathrm{O}$ molecule acts as a kiratically active electrophile, given the inactivity of the more powerful electrophile $\mathrm{H}_{3} \mathrm{O}^{+}$towards the aquo complex. Moreover we find no kinetic isotope effect in $\mathrm{D}_{2} \mathrm{O}$ : the complex $\left[\mathrm{n}-\operatorname{PrCrL}(O D)^{+}\right]$has $k_{9}=6.2 \times 10^{-5} \mathrm{~s}^{-1}\left(25^{\circ} \mathrm{C}, \mathrm{pD}=12\right.$ in $\left.\mathrm{D}_{2} \mathrm{O}\right)$, compared to $\mathrm{k}_{9}=(6.6 \pm 0.3) \times 10^{-5} \mathrm{~s}^{-1}$ for the reaction of $\left[\mathrm{n}-\mathrm{PrCrL}(\mathrm{OH})^{+}\right]$in $\mathrm{H}_{2} \mathrm{O}$. Thus proton transfer from $\mathrm{H}_{2} \mathrm{O}$ to $\mathrm{R}$ is not significantly advanced in the transition state. 
The heterolytic reactions are accompanied by substantial and negative activation entropies as shown in Table I-2. This suggasts a transition state with larger charge separation as compared to that of reactant. Hence, the interpretation we offer is that the rate-limiting step is intramolecular charge transfer to folm an incipient carbanion, and the transition state might be represented as $\left[\mathrm{HOCr} \delta+(L) R \delta \cdots \cdot H-\mathrm{OH}^{+}\right]^{\ddagger}$. We further note that heterolysis applies only to the complex in which the trans Iigand is $\mathrm{OH}^{-}$, not $\mathrm{H}_{2} \mathrm{O}$. The evident role for coordinated $\mathrm{OH}^{-}$is to act as a strong electron donor, thich improves the energetics of carbanion formation.

The aralkyl complexes are not subject to heterolytic solvolysis, even in the case of the trans-hydroxo species. This contrasts with the very slow but easily observed decomposition of $\left(\mathrm{H}_{2} \mathrm{O}\right)_{5} \mathrm{CrCH}_{2} \mathrm{Ph}^{2+} .23$ 
Table I-1. Rate Constants for the Homolysis of $\operatorname{RCr}\left([15] \operatorname{aneN}_{4}\right)\left(\mathrm{H}_{2} \mathrm{O}\right)^{2+}$ Complexes in Aqueous Solutions ${ }^{a}$

\begin{tabular}{lll}
\hline \multicolumn{1}{c}{$\mathrm{R}$} & $\begin{array}{c}\text { Scavenger, } \\
\text { concentration/mM }\end{array}$ & $10^{4} \mathrm{k}_{6} / \mathrm{s}^{-1}$ \\
& & \\
\hline $1-\mathrm{C}_{3} \mathrm{H}_{7}$ & $\left(\mathrm{NH}_{3}\right)_{5} \mathrm{CoBr}^{2+}, 0.63-4.65$ & $5.0 \pm 0.3$ \\
$i-\mathrm{C}_{3} \mathrm{H}_{7}$ & HTMPO, $0.20-1.60$ & $5.0 \pm 0.4$ \\
$\mathrm{p}-\mathrm{CH}_{3} \mathrm{C}_{6} \mathrm{H}_{4} \mathrm{CH}_{2}$ & HTMPO, $0.31-1.67$ & $1.36 \pm 0.01$ \\
$\mathrm{C}_{6} \mathrm{H}_{5} \mathrm{CH}_{2}$ & HTMPO $0.76-2.00$ & $1.24 \pm 0.04$ \\
$\mathrm{p}-\mathrm{BrC}_{6} \mathrm{H}_{4} \mathrm{CH}_{2}$ & HTMPO, $0.23-1.00$ & $1.15 \pm 0.01$ \\
& & \\
\hline
\end{tabular}

at $25.0^{\circ} \mathrm{C}$ with $\left[\mathrm{H}^{+}\right]=1.0 \times 10^{-2} \mathrm{M}, \mu=0.20 \mathrm{M}$, $\left[\operatorname{RCr}\left([15] \operatorname{aneN}_{4}\right)\left(\mathrm{H}_{2} \mathrm{O}\right)^{2+}\right]_{0}=0.02-0.35 \mathrm{mM}$, used always as a limitirg reagen $t$. 
Table I-2. Activation Parameters for the Homolysis and Heterolysis of Organochromium Cations ${ }^{a}$

\begin{tabular}{|c|c|c|c|}
\hline Complex & Reaction & $\Delta \mathrm{H} \neq / \mathrm{kJ} \mathrm{mol}^{-1}$ & $\Delta S \neq / \mathrm{J} \mathrm{mol}^{-1} \mathrm{~K}^{-1}$ \\
\hline $\mathrm{i}-\mathrm{C}_{3} \mathrm{H}_{7} \mathrm{CrL}\left(\mathrm{H}_{2} \mathrm{O}\right)^{2+b}$ & homolysis & $110 \pm 3$ & $62 \pm 6$ \\
\hline $\mathrm{p}-\mathrm{CH}_{3} \mathrm{C}_{6} \mathrm{H}_{4} \mathrm{CH}_{2} \mathrm{CrL}\left(\mathrm{H}_{2} \mathrm{O}\right)^{2+b}$ & homolysis & $111 \pm 2$ & $54 \pm 6$ \\
\hline $\mathrm{C}_{6} \mathrm{H}_{5} \mathrm{CH}_{2} \mathrm{CrL}\left(\mathrm{H}_{2} \mathrm{O}\right)^{2+b}$ & homolysis & $103 \pm 2$ & $28 \pm 5$ \\
\hline $\mathrm{p}-\mathrm{BrC}_{6} \mathrm{H}_{4} \mathrm{CH}_{2} \mathrm{CrL}\left(\mathrm{H}_{2} \mathrm{O}\right)^{2+b}$ & homolysis & $101 \pm 3$ & $22 \pm 9$ \\
\hline$\left(\mathrm{H}_{2} \mathrm{O}\right)_{5} \mathrm{CrCH}_{2} \mathrm{C}_{6} \mathrm{H}_{5}{ }^{2+c}$ & homolysis & 133 & 153 \\
\hline $\mathrm{i}-\mathrm{C}_{3} \mathrm{H}_{7} \mathrm{CrL}(\mathrm{OH})+\mathrm{d}$ & heterolysis & $78 \pm 1$ & $-53 \pm 2$ \\
\hline $\mathrm{n}-\mathrm{C}_{3} \mathrm{H}_{7} \mathrm{CrL}(\mathrm{OH})+\mathrm{d}$ & heterolysis & $83 \pm 3$ & $-42 \pm 9$ \\
\hline
\end{tabular}

$a_{L}=[15] \operatorname{aneN}_{4}$.

bIn aqueous solution with $1.0 \times 10^{-2} \mathrm{MH}^{+}$at $\mu=0.20 \mathrm{M}$.

cRef. 5 .

$\mathrm{d}_{[\mathrm{NaOH}]}=\mu=0.82 \mathrm{M}$. 

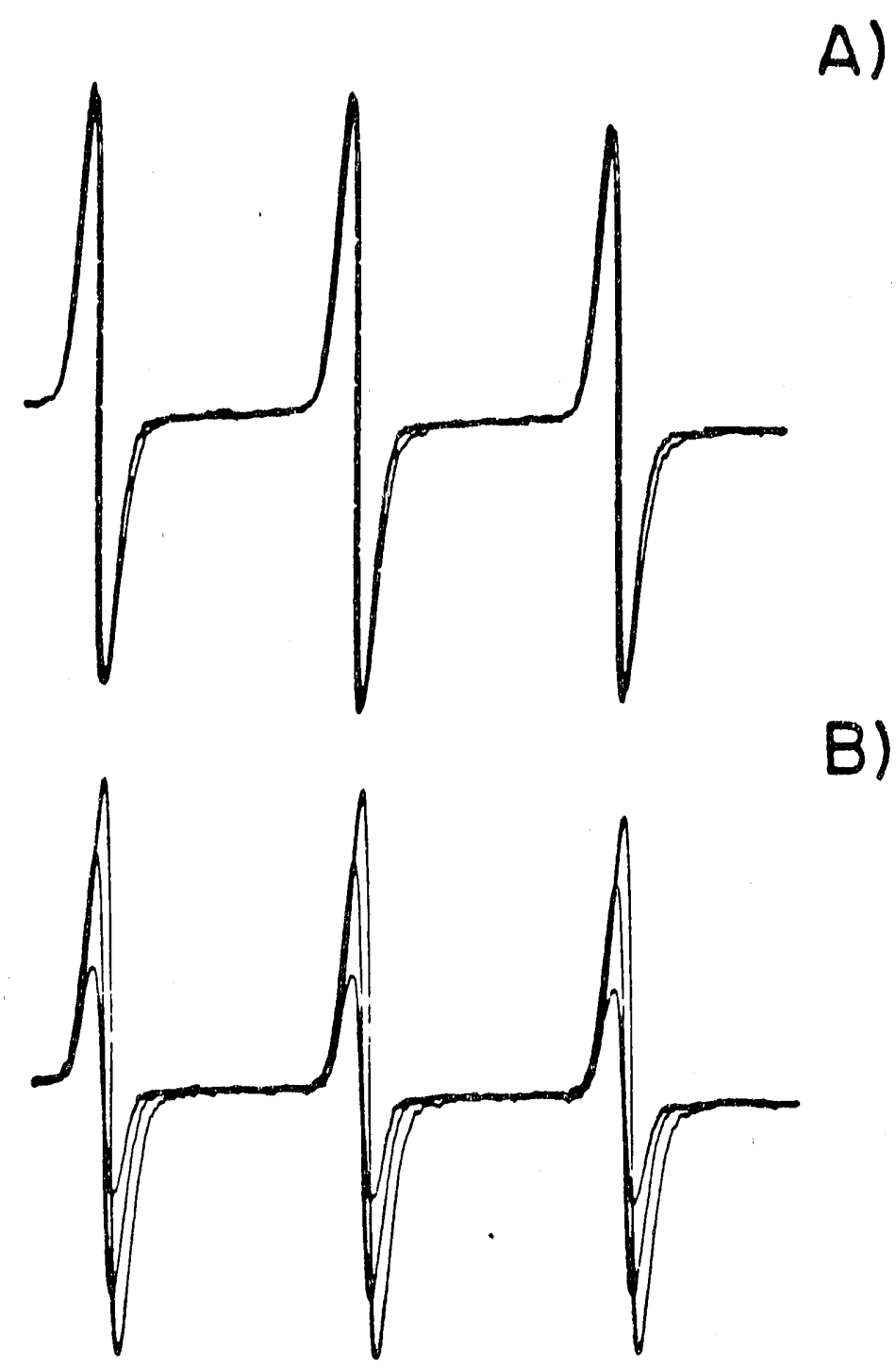

Figure I-1. Changes in the ESR spectrum of the radical scavenger HTMPO in the presence of $\mathrm{i}-\mathrm{C}_{3} \mathrm{H} 7 \mathrm{CrL}(\mathrm{OH})^{+}(\mathrm{A})$ and $\mathrm{i}-\mathrm{C}_{3} \mathrm{H}_{7} \mathrm{CrL}\left(\mathrm{H}_{2} \mathrm{O}\right)^{2+}(\mathrm{B})$, $L=[15]$ aneN $_{4}$. The spectra were recorded on reaction solutions that were kept at $40^{\circ} \mathrm{C}$ for 0 and $15 \mathrm{~min}$ (A) and 0 , 2 , and $12 \mathrm{~min}(\mathrm{~B})$. The ESR spectra were recorded at $15^{\circ} \mathrm{C}$, with a sweep width of $50 \mathrm{G}$. Small fluctuation of frequency with time causes small shifts of central field around $3475 \mathrm{G}$ 


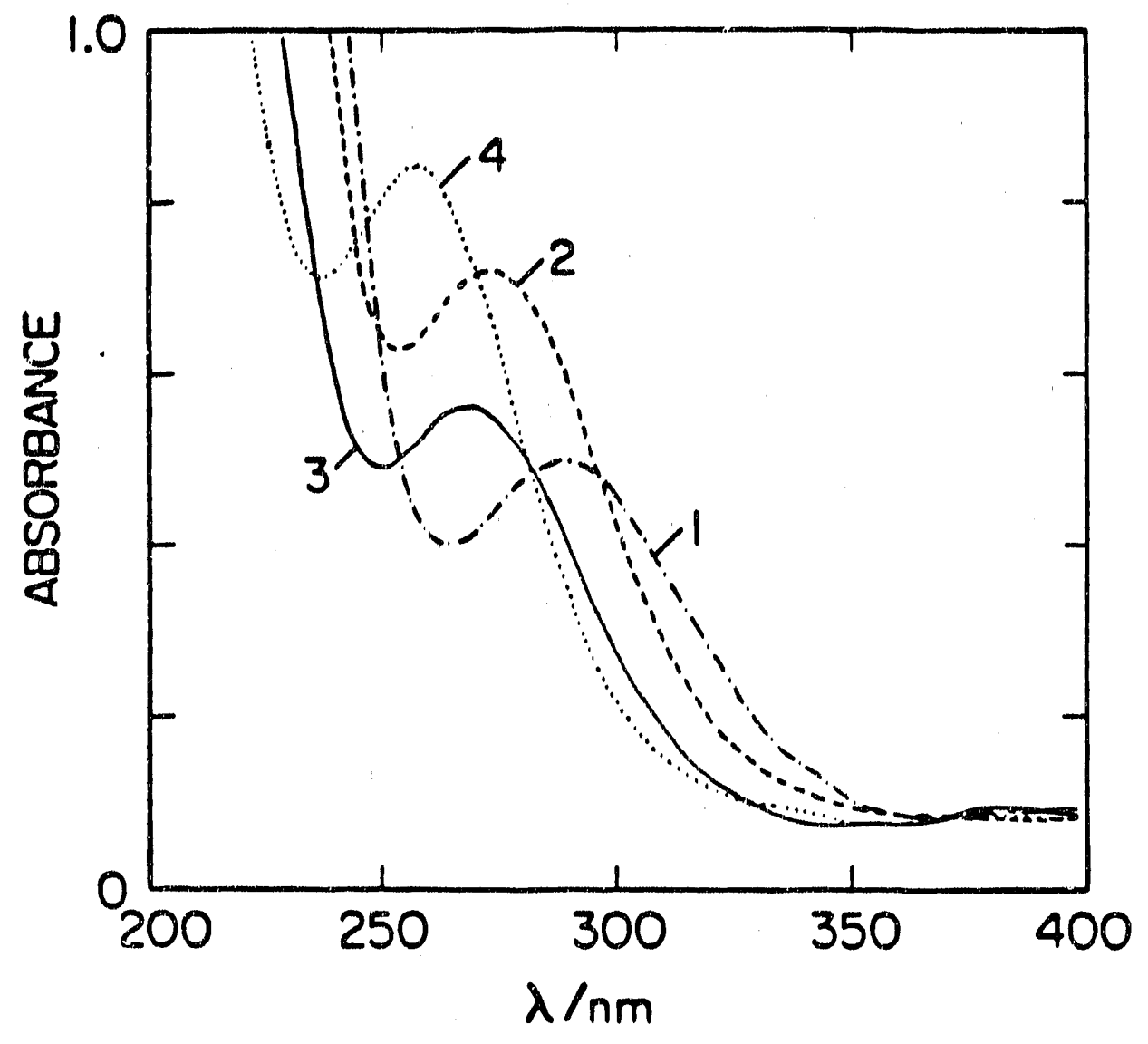

Pigure I-2. Electronic spectra of $\operatorname{RCrL}(A)^{\mathrm{n}+1}$ complexes, $L=[15]_{\text {aneN }}$.

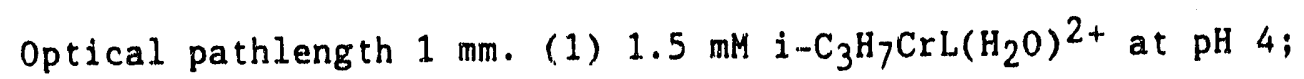

(2) $1.5 \mathrm{mM} \mathrm{i}-\mathrm{C}_{3} \mathrm{H}_{7} \mathrm{CrL}(\mathrm{OH})^{+}$at $\mathrm{pH} \mathrm{7}$;

(3) $2.2 \mathrm{mM} \mathrm{n}-\mathrm{C}_{3} \mathrm{H}_{7} \mathrm{CrL}\left(\mathrm{H}_{2} \mathrm{O}\right)^{2+}$ at pH 4; (4) $2.2 \mathrm{mM}$ $\mathrm{n}-\mathrm{C}_{3} \mathrm{H}_{7} \mathrm{CrL}(\mathrm{OH})+$ at $\mathrm{pH} 7$ 


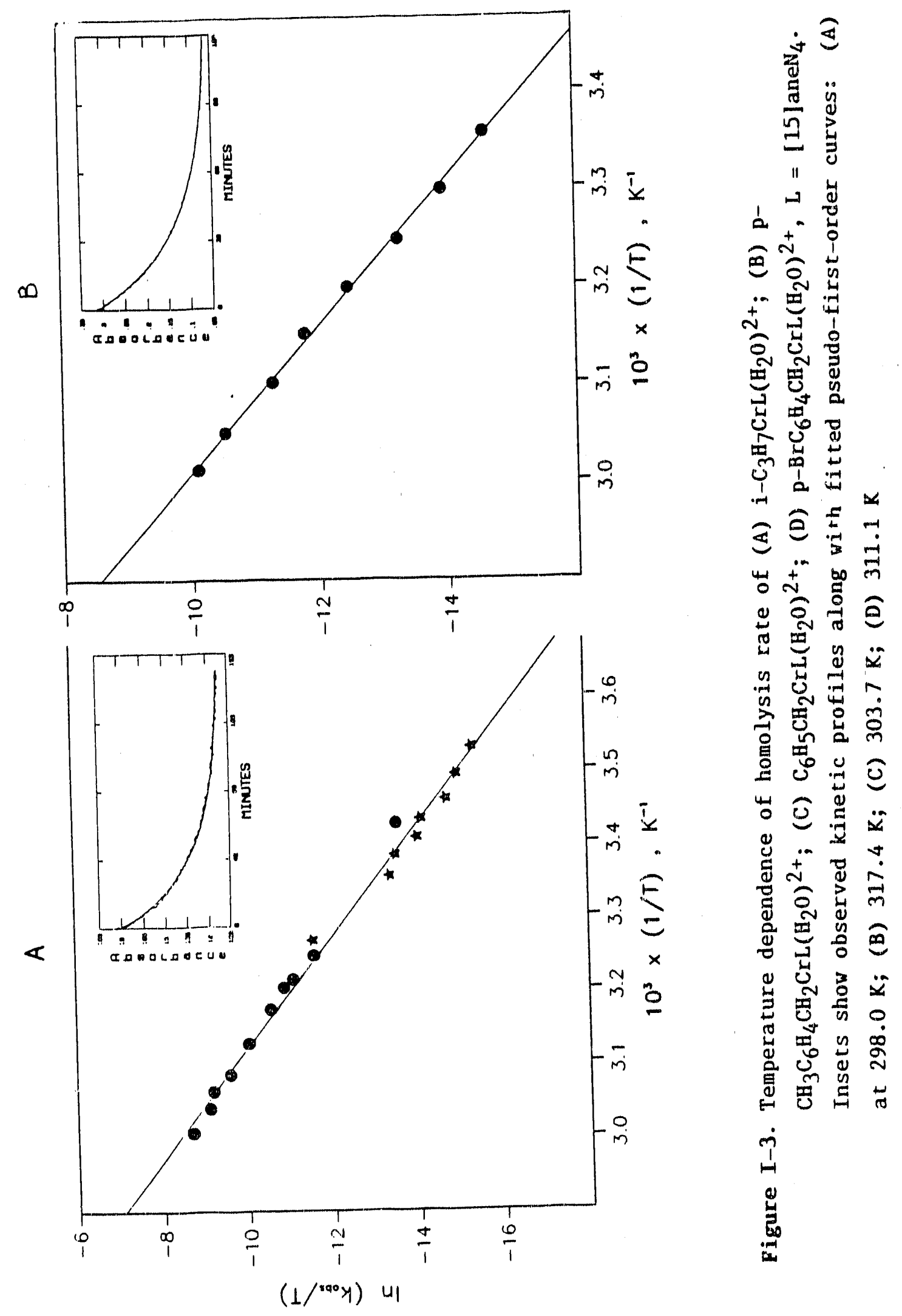



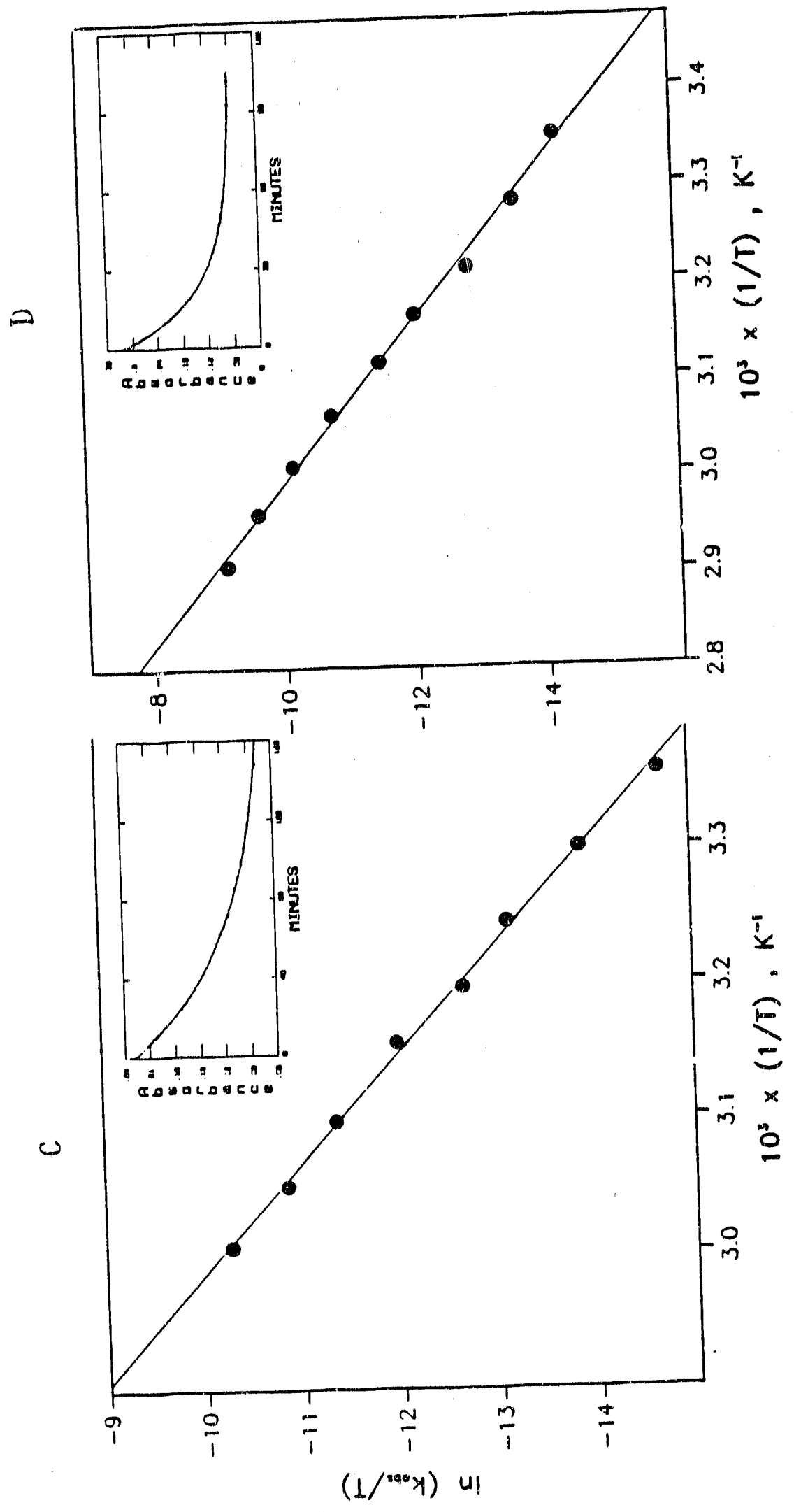

 


\section{REFERENCES}

(1.) Kochi, J. K. "Organometallic Mechanisms and Catalysis", Academic Press, New York, 1978, p 190.

(2) Green, M. In "Mechanisms of Inorganic and Organometallic Fuctions", Twigg, M. V., Ed., Plenum Press, New York, 1983, Vol. $1, \mathrm{p} 221$.

(3) Jotinson, M. D.; Winterton, N. J. Chem. Soc. (A) 1970, 511.

(4) (a) Espenson, J. H. Adv. Inorg. Bioinorg. Mech. 1982, 1, 1-62; (b) Prog. Inorg. Chem. 1983, 30, 189-212.

(5) Nohr, R. S.; Espenson, J. H. J. Am. Chem. Soc. 1975, 97, 3392.

(6) Halpern, J. Acc. Chem. Res. 1982, 15, 238.

(7) Samuels, G. J.; Espenson, J. H. Inorg. Chem. 1979, 18, 2587.

(8) Diehl, H.; Clark, H.; Willard, H. H. Inorg. Synth. 1939, 1, 186.

(9) HTMPO $=4$-hydroxy-2,2,6,6-n te trame thylpiperidinyloxyl.

(10) Mossoba, M. M.; Makino, K.; Riesz, P. J. Phys. Chem. 1984, 88, 4717.

(12) Kelley, D. G.; Bakac,A.; Espenson, J. H., submitted for publication. Chemistry Departinent, Iowa State University.

(13) Qualitative tests showed a very rapid reaction between $\left(\mathrm{H}_{2} \mathrm{O}\right)_{2} \mathrm{CrL}^{2+}$ and $\left(\mathrm{NH}_{3}\right)_{5} \mathrm{CoBr}^{2+}$. The cobalt(III) complex is also reduced very rapidly by $\mathrm{Cr}\left(\mathrm{H}_{2} \mathrm{O}\right)_{6}{ }^{2+}$. (Candlin, J. P.; Halpern, J.; Trimm, D. L. J. Am. Chem. Soc. 1964, 86, 1.019).

(14) The protonation and deprotonation of a nitrogen of $L$ can probably be ruled out at this $\mathrm{pH}$. Also, the deprotonation of a coordinated 
molecule of $\mathrm{H}_{2} \mathrm{O}$ in $\left(\mathrm{H}_{2} \mathrm{O}\right)_{2} \mathrm{CrL}^{3+}$ is known to have a pKa of 2.9 (see ref. 15).

(15) Richens, D. T.; Adzamli, I. K.; Leupin, P.; Sykes, A. G. Inorg. Chem. 1984, 23, 3065 .

(16) Koenig, T. W.; Hay, B. P.; Finke, R. G. Polyhedron 1988, 7, 1499.

(17) Shi, S.; Espenson, J. H.; Bakac, A. J. Am. Chem. Soc. 1990, 112, 1841 .

(18) Ogino, H.; Shoji, M.; Abe, Y.; Shimura, M.; Shimoi, M. Inorg. Chem. $1987,26,2542$.

(19) (a) Kirker, G. W.; Bakac, A.; Espenson, J. H. J. Ain. Chem. Soc. 1982, 104, 1249; (b) Bakac, A.; Espensun, J. H. J. Am. Chem. Soc. $1990,112,2273$.

(20) Ruichardt, C. Top. Curr. Chem. 1.980, 88, 1.

(21) Cohen, H.; Meyerstein, D. Inorg. Chem. 1984, 23, 84.

(22) Rotman, A.; Cohen, H.; Meyerstein, D. Inorg. Chem. 1985, 24, 4158.

(23) Kita, P.; Jordan, R. B. Inorg. Chem. 1989, 28, 3489. 
PART II. STRUCTURE AND REACTIVITY OP ORGANOCEROMIUI MACROCYCLES WITH IODINE BY CHAIN AND RLECTROPAILIC MECAANISHS 


\section{INTRODUCTION}

The cleavage of metal-carbon bonds by halogens has been fairly widely studied. 1 Generally, two mechanisms are operative. One is electrophilic substitution, of ten an $S_{E} 2$ process, that cleanly converts reactants to products. This is usually accompanied by inversion of stereochemistry at the $\alpha$-carbon atom if the substrate is a transition metal complex with a high coordination number. The $S_{E} 2$ mechanism is a two-electron process that occurs without the intervention of reaction intermediates. The second mechanism is a one-electron transfer process, in which the initial step is the formation of a caged radical pair, [RM+, $\left.\mathrm{X}_{2}{ }^{-}-\right\}$. The electron transfer step may inftiate a chain sequence for halogenolysis.

The literature in the field includes extensive studies on a series of organochromium complexes, $\left(\mathrm{H}_{2} \mathrm{O}\right)_{5} \mathrm{CrR}^{2+}, 2$ and macrocyclic complexes of cobalt, including the cobaloximes, $\mathrm{RCo}(\mathrm{dmgH}){ }_{2} \mathrm{~B}\left(\mathrm{~B}=\mathrm{H}_{2} \mathrm{O}\right.$, pyridine, etc.).3-6 The former complexes adopt an $S_{E} 2$ mechanism for halogenolysis, whereas the mechanism for the cobaloximes includes an electron transfer step. The participation of inorganic transition metal complexes in photoinduced chain reactions was also noticed before. 7

We have turned our attention to iodinolysis reactions of a different group of organometallic complexes. This is a series of alkyl and aralkyl derivatives of a chromium macrocycle, $\mathrm{RCr}\left([15] \mathrm{aneN}_{4}\right) \mathrm{H}_{2} \mathrm{O}^{2+} .8$ Cleavage of the carbon-chromium bond in such complexes by electrophilic mercury(II) ions occurs strictly by an $S_{E} 2$ mechanism. ${ }^{9}$ Halogenolysis reactions have 
rot been previously investigated for these complexes. Rather to our surprise, we find that the mechanism for the reaction of $\mathrm{RCr}\left(\left[15 \mathrm{JaneN}_{4}\right) \mathrm{H}_{2} \mathrm{O}^{2+}\right.$ with $\mathrm{I}_{2}$ changes along the series of $\mathrm{R}$ groups and both electrophilic and oxidative mechanisms have to be considered. We present the results of kinetic investigations in this paper.

No crystal structure data were available for the complexes $\mathrm{RCr}\left([15]\right.$ aneN $\left._{4}\right) \mathrm{H}_{2} \mathrm{O}^{2+}$ until now. In this work ve have determined by $\mathrm{X}$-ray diffraction the structure of the perchlorate salt of the complex with $R=$ 4-bromobenzyl. Among other factors, we were interested in establishing the identity of the compound on more secure grounds, in the extent of steric hindrance at the chromium-carbon bond, and in the ground-state steric influence, as measured by the extent of the elongation of the bond to the trans water inolecule. 


\section{EXPERIMENTAL SECTION}

Materia].s. The chromium(II) complex, $\mathrm{CrL}^{2+}\left(\mathrm{L}=[15] \mathrm{aniN}_{4}\right)$ was prepared by mixing stoichiometric amounts of $\mathrm{CrCl}_{2} \cdot 4 \mathrm{H}_{2} \mathrm{O}^{10}$ and, ligand $\mathrm{L}$ (Strem Chemical Co.) in aqueous solution. 8 The organochromium complexes, $\mathrm{RCrL}\left(\mathrm{H}_{2} \mathrm{O}\right)^{2+},\left(\mathrm{R}=\mathrm{CH}_{3}, \mathrm{C}_{2} \mathrm{H}_{5}, 1-\mathrm{C}_{3} \mathrm{H}_{7}\right.$, and $\left.1-\mathrm{C}_{4} \mathrm{H}_{9}\right)$ were prepared from $\mathrm{CrL}^{2+}$ and the corresponding organic bromide following the published procedure. 8 Similarly, sec-alkyl and aralkyl complexes were prepared from the organic halides. All organochromium macrocycles were separated and purified by ion exchange on Sephadex $\mathrm{C}-25$. Iodine solutions were prepared by dissolving the AR grade reagent in $0.01 \mathrm{M}$ perchloric acid.

Iodine and triodide ion concentrations were determined spectrophotometrically at $467 \mathrm{~nm}\left(\varepsilon 733 \mathrm{M}^{-1} \mathrm{~cm}^{-1}\right.$ for $\left.\mathrm{I}_{2}\right)$ and $352 \mathrm{~nm}(2.46$ $\times 10^{4} \mathrm{M}^{-1} \mathrm{~cm}^{-1}$ for $\left.\mathrm{I}_{3}^{-}\right) .11$ The extinction coefficients for $\mathrm{RCrL}\left(\mathrm{H}_{2} \mathrm{O}\right)^{2+}$ were taken from the literature. ${ }^{8}$ For $\mathrm{R}=\mathrm{CH}_{3}, \lambda_{\max } / \mathrm{nm}\left(\varepsilon / \mathrm{M}^{-1} \mathrm{~cm}^{-1}\right)$ are $258\left(3.30 \times 10^{3}\right)$ and $375\left(2.27 \times 10^{2}\right) ; \mathrm{C}_{2} \mathrm{H}_{5}, 264\left(3.10 \times 10^{3}\right)$ and 383 $\left(3.87 \times 10^{2}\right) ; 1-\mathrm{C}_{3} \mathrm{H}_{7}, 265\left(3.44 \times 10^{3}\right)$ and $383\left(4.65 \times 10^{2}\right)$; and $1-\mathrm{C}_{4} \mathrm{H}_{9}$, $268\left(3.30 \times 10^{3}\right)$ and $383\left(4.59 \times 10^{2}\right)$. The molar absorptivities listed were used to determine the concentrations of the organochromium ions. The new complex prepared in this work, $4-\mathrm{BrC}_{6} \mathrm{H}_{4} \mathrm{CH}_{2} \mathrm{CrL}\left(\mathrm{H}_{2} \mathrm{O}\right)^{2+}$, has maxima at $245 \mathrm{~nm}\left(\varepsilon 1.07 \times 10^{4} \mathrm{M}^{-1} \mathrm{~cm}^{-1}\right), 281\left(9.82 \times 10^{3}\right), 303\left(8.83 \times 10^{3}\right)$, and $361\left(2.40 \times 10^{3}\right)$. 
Rinetics. The kinetics of the reaction of $\mathrm{CrL}\left(\mathrm{H}_{2} \mathrm{O}\right)^{2+}$ with $4-\mathrm{BrC}_{6} \mathrm{H}_{4} \mathrm{CH}_{2} \mathrm{Br}$ were followed at room temperature at $305 \mathrm{~nm}$ with a DurrumDionex stopped-flow spectrophotometer. Anaerobic conditions were required by the extreme sensitivity of the chromium(II) complex towards oxygen.

The kinetic study of the chain reaction between $I_{2}$ and $4-\mathrm{BrC}_{6} \mathrm{H}_{4} \mathrm{CH}_{2} \mathrm{CrL}\left(\mathrm{H}_{2} \mathrm{O}\right)^{2+}$ was conducted with the chromium complex in excess over iodine in solutions containing free lodide. The progress of the reaction was monttored by following the disappearance of $\mathrm{I}_{3}$ - at $\lambda 352 \mathrm{~nm}$. The kinetics of the electrophilic reactions of the primary alkyl complexes were studied under pseudo-first-order conditions with $\mathrm{RCrL}^{2+}$ in excess $\left(\mathrm{R}=\mathrm{CH}_{3}, \mathrm{C}_{2} \mathrm{H}_{5}, 1-\mathrm{C}_{3} \mathrm{H}_{7}, 1-\mathrm{C}_{4} \mathrm{H}_{9}\right)$. For the case of $\mathrm{R}=1-\mathrm{C}_{3} \mathrm{H}_{7}$ the results were also checked with $I_{2}$ in excess. All reactions with $I_{2}$ were conducted at $25.0 \pm 0.1{ }^{\circ} \mathrm{C}$ at a constant ionic strength of $0.20 \mathrm{M}$ controlled by $\mathrm{NaClO}_{4}$ and a constant $\mathrm{pH}$ of 2.00 , controlled by perchloric acid.

Crystal Growth. Orange crystals of $\left[4-\mathrm{BrC}_{6} \mathrm{H}_{4} \mathrm{CH}_{2} \mathrm{CrL}\left(\mathrm{H}_{2} \mathrm{O}\right)\right]\left(\mathrm{ClO}_{4}\right)_{2} \cdot \mathrm{THF}$ were grown from a sample of the purified organochromium cation in a mixture of THF and water in an ESR tube encapsulated within a sealed test tube. This system was employed to slow the temperature change as the solution was being cooied. This procedure afforded crystals suitable for $X$-ray diffraction. 
X-Ray Data and Structure. A crystal of approximate dimensions 0.30 $\times 0.14 \times 0.13 \mathrm{~mm}$ was used to collect $\mathrm{X}$-ray diffraction data with an Enraf-Nonius CAD-4 diffractometer. The cell constants were determined from reflections found by an automated search routine. An empirical absorption correction was based on a series of psi-scans. Pertinent results are given in Table II-1.

The positions of $\mathrm{Cr}, \mathrm{Br}$, and $\mathrm{Cl}$ atoms were taken from an E-map produced by direct methods. Trial positions of other atoms were determined by a difference Fourier map and subsequent least-squares refinement. Because of the disorder in perchlorate anions and THF molecules, as well as a relatively low observation to parameter ratio, the phenyl group was subsequently refined as a rigid hexagon with $\mathrm{C}-\mathrm{C}$ bond lengths of $1.395 \AA$ and the perchlorete ions as rigid tetrahedra with Cl-0 bond lengths of $1.50 \AA$. Based on the difference map, two orientations were assigned to each of the two independent perchlorate groups, with occupancy factors of $0.46: 0.54$ and $0.81: 0.19$. Hydrogen atoms were not included in the refinement but were used for the determination of $F_{\text {calc. }}$. Final $R$ and $R_{W}$ values are shown in Table IT-1. All calculations were performed on a Digital Equipment Corp. Micro Vax II computer. The refinement was carried out with the SHELX-76 package.

Spectrum and Product Analysis. The UV-visible spectra were taken with a Perkin-Elmer Lambda Array 3840 UV/vis spectrophotometer. The $\mathrm{I}_{3}-$ jon was identified spectrophotometrically. The organic products were identified with a Hewlett-Packard Model 5790 gas chromatograph with a 6' 
column packed with OV-101 stationary phase. The instrument was calibrated by use of standard organic halides. 


\section{RESULTS AND DISCUSSION}

Formation of $4-\mathrm{BrC}_{6} \mathrm{~B}_{4} \mathrm{CH}_{2} \mathrm{CrL}\left(\mathrm{B}_{2} \mathrm{O}\right)^{2+}$. The reaction between the $4-\mathrm{BrC}_{6} \mathrm{H}_{4} \mathrm{CH}_{2} \mathrm{Br}(\mathrm{RBr})$ and $\mathrm{CrL}^{2+}$ was studied in $10 \%$ ethanol-water, since the bromide is insoluble in strictly aqueous solution. $\mathrm{CrL}^{2+}$ was used in at least ten-fold excess over $\mathrm{RBr}$. The reaction followed pseudo-first-order kinetics in each run, and the plot of $k_{\text {obsd }} v s\left[\mathrm{CrL}^{2+}\right]$ was linear, as depicted in Figure II-1. The second-order rate constant obtained is 3.73 $\times 10^{4} \mathrm{y}^{-1} \mathrm{~s}^{-1}$.

The reaction produces the indicated organochromium(III) cation, as shown by its UV/visible spectrum (after separation by ion exchange chromatography) and by $\mathrm{x}$-ray crystallography. The rate constant of $3.7 \mathrm{x}$ $10^{4} \mathrm{M}^{-1} \mathrm{~cm}^{-1}$ is slightly higher than the value for $\mathrm{PhCH}_{2} \mathrm{Br}, \mathrm{k}=1.9 \times 10^{4}$ $\mathrm{M}^{-1} \mathrm{~s}^{-1.8}$ This small difference is consistent with the proposed free radical mechanism for such reactions:

$$
\begin{aligned}
& \mathrm{CrL}\left(\mathrm{H}_{2} \mathrm{O}_{2}{ }^{2+}+\mathrm{RBr} \longrightarrow \operatorname{BrCrL}\left(\mathrm{H}_{2} \mathrm{O}\right)^{2+}+\mathrm{R}^{\circ}+\mathrm{H}_{2} \mathrm{O} \quad \mathrm{k}_{1}\right. \\
& \mathrm{CrL}\left(\mathrm{H}_{2} \mathrm{O}_{2}{ }^{2+}+\mathrm{R} \longrightarrow \operatorname{RCrL}\left(\mathrm{H}_{2} \mathrm{O}\right)^{2+}+\mathrm{H}_{2} \mathrm{O} \quad \mathrm{k}_{2}\right. \text { (fast) }
\end{aligned}
$$

According to this scheme, $-d[R B r] / d t=k_{1}\left[C r L^{2}\right][R B r]$. Thus the values of the rate constants cited abcve represent $k_{1}$. The $4-B r$ derivative is expected to react more rapidly than the unsubstituted benzyl. complex owing to the electron-withdrawing properties of bromine and resonance stabilization of the alkyl radical by the para-bromine. 
The complex $4-\mathrm{BrC}_{6} \mathrm{H}_{4} \mathrm{CH}_{2} \mathrm{CrL}\left(\mathrm{H}_{2}\right)^{2}+$ is more stable toward air than $\mathrm{PhCH}_{2} \mathrm{CrL}\left(\mathrm{H}_{2} \mathrm{O}\right)^{2+}$ is. In botlı cases the reaction proceeds by unimolecular homolysis. 12 The electron withdrawing effect of the para bromine makes the $\mathrm{Cr}-\mathrm{C}$ bond more polar thereby retarding the homolysis. The complex $4-\mathrm{BrC}_{6} \mathrm{H}_{4} \mathrm{CH}_{2} \mathrm{CrL}\left(\mathrm{H}_{2} \mathrm{O}\right)^{2+}$ is quite stable toward acid; it can be stored in solution at $\mathrm{pH} 2$ and $0{ }^{\circ} \mathrm{C}$ for weeks.

The crystal structure of $\left[\mathrm{p}-\mathrm{BrC}_{6} \mathrm{H}_{4} \mathrm{CH}_{2} \mathrm{CrL}\left(\mathrm{H}_{2} \mathrm{O}\right)\right]\left(\mathrm{ClO}_{4}\right)_{2} \cdot \mathrm{THF}$ is shown in Figure II-2. The cation adopts a distorted octahedral structure with a molecule of water trans to the $\mathrm{Cr}-\mathrm{C}$ bond. The relevant bond lengths and bond angles are summarized in Table II-2 and Table II--3. The Cr-C bond length $(2.14 \AA)$ in this cation is slightly longer than the reported values of other stable organochromium complexes $(2.06 \AA$ in trans$\left[\left(\mathrm{CH}_{2} \mathrm{Cl}\right) \mathrm{Cr}(\mathrm{acac})_{2} \cdot \mathrm{H}_{2} \mathrm{O}\right]$ and $2.077-2.129 \AA$ in trans $-\mathrm{RCr}(\mathrm{acac})_{2} \mathrm{py}$, for $\mathrm{R}=$ $\mathrm{CHCl}_{2}$ and $\mathrm{CH}_{2} \mathrm{Cl}$, respectively).13,14 The $\mathrm{Cr}-\mathrm{C}(1)-\mathrm{C}(2)$ angle of $123^{\circ}$ is also larger than that for a typical $\mathrm{sp}^{3}$ carbon. All of these deviations are due to the steric repulsion between the para-bromobenzyl group and the bulky macrocyclic ligand. Similar distortions have been observed before. 13,14 We also note the large $\mathrm{Cr}-\mathrm{C}-\mathrm{Si}$ bond angle $\left(127.9^{\circ}-128.3^{\circ}\right)$ in the compound cis-[Me $3 \mathrm{SiCH}_{2} \mathrm{Cr}$ (bipy) $] \mathrm{I} .15$

It is noted from Pigure II-2 that the coordinated nitrogens adopt a configuration with three of the four $\mathrm{N}-\mathrm{H}$ bonds pointing upward and one downward. This asymmetric configuration makes the two sides of the $\mathrm{CrN}_{4}$ plane different (designated as side $A$ and side $B$, respectively, in Figure II-2). A space filling model shows that this asymmetric binding of [15] aneN $\mathrm{N}_{4}$ to chromium(III) results in the A side being less crowded than 
the B side. It is therefore not too surprising that the 4-bromobenzy 1 group binds preferentially to the A side even though the $\mathrm{CrN}_{4}$ plane is quite flat.

A comparison between the $\mathrm{Cr}$ (III) $-\mathrm{OH}_{2}$ bond length in trans$4-\mathrm{BrC}_{6} \mathrm{H}_{4} \mathrm{CH}_{2} \mathrm{CrL}\left(\mathrm{H}_{2} \mathrm{O}\right)^{2+}(2.13 \AA)$ and that in trans-ClCrL$\left(\mathrm{H}_{2} \mathrm{O}\right)^{2+}(2.04$ A) ${ }^{16}$ can also be made. The reported crystal structure of the chloro complex has the $\mathrm{H}_{2} \mathrm{O}$ molecule bound to the more open $\mathrm{A}$ side, rather than the $B$ side as in the case of the organometallic complex. Hence both the trans influence of the $\mathrm{Cr}(\mathrm{III})-\mathrm{C}$ bond and the steric crowdedness of the $\mathrm{B}$ side might contribute to the elongation of the $\mathrm{Cr}$ (III) $-\mathrm{OH}_{2}$ bond in the 4-bromobenzyl complex.

Electrophilic Substitution Reactions with Iodine. All the primary alkyl chromium complexes, $\operatorname{RCrL}\left(\mathrm{H}_{2} \mathrm{O}\right)^{2+}$, are quite stable toward $\mathrm{O}_{2}$. No reaction was observed in 60 min in oxygen-saturated solutions, $\left[\operatorname{RCrL}\left(\mathrm{H}_{2} \mathrm{O}\right)^{2+}\right] \sim 3 \times 10^{-4} \mathrm{M}$. These solutions are also stable toward acidolysis. No significant reaction was observed in $60 \mathrm{~min}$ in solutions of $\mathrm{RCrL}\left(\mathrm{H}_{2} \mathrm{O}\right)^{2+}$ containing $0.01-0.4 \mathrm{M} \mathrm{HClO}_{4}$ at room temperature.

The $\mathrm{Cr}-\mathrm{C}$ bond in $\mathrm{RCrL}\left(\mathrm{H}_{2} \mathrm{O}\right)^{2+}$ can be easily cleaved heterolytically by $I_{2}$. Advantage was taken of the strong light absorption of $\mathrm{I}_{3}{ }^{-}$at 352 $\mathrm{nm}$ to monitor the reaction which proceeds according to the net equation II-3. All the exneriments were done in the presence of excess $I^{-}$to

$$
\mathrm{I}_{2}+\mathrm{RCrL}\left(\mathrm{H}_{2} \mathrm{O}\right)^{2+}+\mathrm{H}_{2} \mathrm{O} \longrightarrow \mathrm{I}^{-}+\mathrm{RI}+\left(\mathrm{H}_{2} \mathrm{O}_{2} \mathrm{CrL}^{3+}\right.
$$


create the $\mathrm{I}_{3}$ - chromophore. The reaction rate is first-order with respect to both lodine and alkyl chromium concentrations, regardless of which one was used as the limiting reagent.

Since $I_{2}$ and $I_{3}$ - have almost identical reduction potentials, both should be considered as possible electrophiles. To distinguish between them, consider the rate laws in experiments with $\mathrm{I}_{2} / \mathrm{I}_{3}^{-}$as the limiting reagent. We consider three cases, in which $\mathrm{K}_{\mathrm{f}}$ represents the formation constant of $\mathrm{I}_{3}{ }^{-}$, and $k_{\text {obsd }}$ the value of $-\mathrm{d} \ln \left[\mathrm{I}_{2}\right] / \mathrm{dt}$ :

(1) $\mathrm{I}_{3}-$ is the only active electrophile:

$$
k_{\text {obsd }}=\frac{\left\{k_{I_{3}} K_{f}\left[I^{-}\right]\right\}\left[\operatorname{RCrL}\left(\mathrm{H}_{2} 0\right)^{2+}\right]}{1+k_{f}\left[I^{-}\right]}
$$

(2) $I_{2}$ is the only active electrophile:

$$
k_{\text {obsd }}=\frac{k_{I_{2}}\left[\operatorname{RCrL}\left(\mathrm{H}_{2} 0\right)^{2+}\right]}{1+k_{f}\left[I^{-}\right]}
$$

(3) Both $\mathrm{I}_{3}^{-}$and $\mathrm{I}_{2}$ are active electrophiles:

$$
k_{\text {obsd }}=\frac{\left\{k_{I_{3}} k_{f}\left[I^{-}\right]+k_{I_{2}}\right\}\left[\operatorname{RCrL}\left(\mathrm{H}_{2} 0\right)^{2+}\right]}{1+k_{f}\left[I^{-}\right]}
$$

The distinction between these cases clearly lies in the form of the 
dependence of $k_{\text {obsd }}$ upon $\left[I^{-}\right]$. For all the primary alkyl chromiun complexes studied, the pseudo-first-order rate constant decreases as the free iodide concentration increases, as shown in Figure II-3. The clear linearity in the plots of kobsd versus $\left[\operatorname{RCrL}\left(\mathrm{H}_{2} \mathrm{O}\right)^{2+}\right] /\left(1+\mathrm{K}_{\mathrm{f}}\left[\mathrm{I}^{-}\right]\right)$ shows that only $I_{2}$ is the active electrophile and the rate law of eq IJ -5 applies. Thus $\mathrm{I}_{3}-$ serves only as a chromophore useful in following the progress of the reaction, and is in instantaneous equilibrium with $I_{2}\left(I_{3^{-}}==I^{-}+I_{2}\right)$. Consistent with that, the kinetics were unaffected by the variation of lonic strength in the range $5 \times 10^{-3}$ to $0.8 \mathrm{M}$.

The only organic product of the reaction was identified by gas chromatography as the alkyl iodide. As an independent test for the formation of $\mathrm{RI}$, we conducted a two stage reaction. In the first stage of this process, the reaction between $I_{2}$ and the organochromium macrocycle $\mathrm{RCrL}\left(\mathrm{H}_{2} \mathrm{O}\right)^{2+}$ (here $\mathrm{R}=\mathrm{C}_{2} \mathrm{H}_{5}, 1-\mathrm{C}_{3} \mathrm{H}_{7}$, and $4-\mathrm{BrC}_{6} \mathrm{H}_{4} \mathrm{CH}_{2}$ ) was carrled out with a slight excess of the latter. Then a solution of $\left(\mathrm{H}_{2} \mathrm{O}\right){ }_{2} \mathrm{CrL}^{2+}$ was added to react with any $\mathrm{RI}$ formed. Upon this addition the spectrum of $\mathrm{RCrL}\left(\mathrm{H}_{2} \mathrm{O}\right)^{2+}$ quantitatively reappeared. This confirms the quantitative production of RI in the initial reaction with iodine as given in eq II-3.

other lines of evidence supporting the mechanism were obtained from stoichiometric relationships. A spectrophotometric titration (Figure II-4) shows the stoichiometric ratio of $\mathrm{I}_{2}: \mathrm{EtCrL}\left(\mathrm{H}_{2} \mathrm{O}\right)^{2+}$ to be $1: 1$. The absorbance changes with either $I_{2}$ in excess (no free $I^{-}$ added) or $\mathrm{RCrL}\left(\mathrm{H}_{2} \mathrm{O}\right)^{2+}$ in excess (free $\mathrm{I}^{-}$added) are consistent with the $1: 1$ stoichiometry. In the case of $1-\mathrm{C}_{3} \mathrm{H}_{7} \mathrm{CrL}\left(\mathrm{H}_{2} \mathrm{O}\right)^{2+}$, a kinetic 
study was also conducted with $\mathrm{I}_{2}$ in excess (no free $\mathrm{I}^{-}$added) affording the same second-order rate constant as shown in Table II-3.

The slopes in Figure II-3 give the second-order rate constants for the bimolecular reaction between $\mathrm{I}_{2}$ and $\mathrm{RCrL}\left(\mathrm{H}_{2} \mathrm{O}\right)^{2+}(\mathrm{eq} \mathrm{II}-3)$, as shown in the applicable rate law, eq II-5. The second-order rate constants are summarized in Table II-4. The decrease in rate constant from $R=$ Me $(k=$ $\left.4.7 \times 10^{3} \mathrm{M}^{-1} \mathrm{~s}^{-1}\right)$ to $\mathrm{n}-\mathrm{Bu}\left(8.9 \mathrm{M}^{-1} \mathrm{~s}^{-1}\right)$ is to be noted. In particular, this trend points to an $\mathrm{S}_{\mathrm{E}} 2$ mechanism proceeding with inversion of configuration at carbon. The values reflect a trend in which the rate constant declines as the alkyl group gets bulkier because of increasing steric hindrance on the alpha carbon from methyl to 1-butyl. 2

Chain Reaction between $4-\mathrm{BrC}_{6} \mathrm{~B}_{4} \mathrm{CH}_{2} \mathrm{CrL}\left(\mathrm{H}_{2} \mathrm{O}\right)^{2+}$ and Iodine. When the chromium complex is present in excess $\left(\sim 10^{-4} \mathrm{M}\right)$, the reaction is halforder with respect to the iodine concentration, as illustrated in Pigures II-5 and II-6. Under those conditions, the presence of $\mathrm{O}_{2}$ results in a much slower reaction and a pseudo-first-order kinetic profile. A decrease in the concentration of the chromium complex to $-10^{-5} \mathrm{M}$, while keeping the $I_{2}$ in excess, also results in a pseudo-first-order trace even under strictly anaerobic conditions. The reaction proceeds much more rapidly when the chromium complex is used as excess reagent (at $-10^{-4} \mathrm{M}$ level) than it does when iodine is present in excess (at the same $210^{-4} \mathrm{M}$ level). These observations suggest a free radical chain pathway which requires a relatively high concentration of $4-\mathrm{BrC}_{6} \mathrm{H}_{4} \mathrm{CH}_{2} \mathrm{CrL}\left(\mathrm{H}_{2} \mathrm{O}\right)^{2+}$ and anaerobic conditions to proceed. 
Several extraneous reagents were used to diagnose the reaction mechanism. This entailed the addition of a substance $\left(\mathrm{O}_{2}, \mathrm{Cu}^{2+}\right.$, or $\left.\mathrm{Fe}^{2+}\right)$ that might fulfill a chain breaking role. Blank experiments confirmed the absence of a reaction between each of these reagents and the bromobenzylchromium cation.

Addition of $\mathrm{O}_{2}(<1 \mathrm{mM})$ or $\mathrm{CuCl}_{2}(4 \mathrm{mM})$ significantly retarded the reaction and changed the appearance of the kinetic trace. Pigure II-5 illustrates the unaffected half-order absorbance-time proflle along with ones with added $\mathrm{O}_{2}$ and $\mathrm{Cu}^{2+}$. Dioxygen is well known to react rapidly with free radicals $\left(\mathrm{C}_{2} \mathrm{H}_{5}+\mathrm{O}_{2} \longrightarrow \mathrm{C}_{2} \mathrm{H}_{5} 00 \cdot\right.$, for example, has $\mathrm{k}=4.7 \mathrm{x}$ $\left.10^{9} \mathrm{M}^{-1} \mathrm{~s}^{-1}\right), 17$ and presumably plays this chain-breaking role in the overall reaction scheme. The oxidation of benzyl radicals by $\mathrm{Cu}^{2}+$ has been established as well: 18

$$
\mathrm{PhCH}_{2}{ }^{+}+\mathrm{Cu}^{2+}+\mathrm{H}_{2} \mathrm{O} \longrightarrow \mathrm{PhCH}_{2} \mathrm{OH}+\mathrm{Cu}^{+}+\mathrm{H}^{+}
$$

The dramatic inhibitory effect of $\mathrm{Cu}^{2+}$ again points to the involvement of $4-\mathrm{BrC}_{6} \mathrm{H}_{4} \mathrm{CH}_{2}$ radical in the chain reaction.

Addition of $\mathrm{Fe}^{2+}$ as $\mathrm{Fe}\left(\mathrm{ClO}_{4}\right)_{2}(\mathrm{aq})(0.04-11 \mathrm{mM})$ effectively decreases the reaction rate as shown in Figure II-5. The kinetic profile fits a fractional order between 0.5 and 1 . The reaction

$$
\mathrm{Fe}^{2+}+\mathrm{I}_{2}^{-} \longrightarrow \mathrm{Fe}^{3+}+2 \mathrm{I}^{-}
$$


with $k_{8}=6 \times 10^{6} \mathrm{M}^{-1} \mathrm{~s}^{-1}, 19$ is believed to be the reason for the retardation by $\mathrm{Fe}^{2+}$. Hence $\mathrm{I}_{2}{ }^{-}$- is suggested as another chain-carrying radical intermediate.

A more detailed analysis of the kinetics of the chain reaction is now given. A plot of the instantaneous reaction rate versus the average concentration of $I_{2}$ in the interval as a double logarithmic plot gave lines of slopes between 0.47 and 0.58 . In other words, the order of the reaction with respect to $\left[I_{2}\right]$ appears to be $1 / 2$. The rate law at a constant concentration of the bromobenzyl chromium complex is thus:

$$
-d\left[I_{2}\right] / d t=k_{o b s d}\left[I_{2}\right]^{1 / 2}
$$

This was tested by application of the integrated half-order equation; plots of the kinetic data as $\left(A_{t}-A_{\infty}\right)^{1 / 2}$ versus time give a straight line as depicted in Figure II-6. The slope of the half-order plot is a function of the concentration of the excess bromobenzyl chromium reagent. A plot of In $k_{\text {obsd }} v \mathrm{~s}$ in $\left[4-\mathrm{BrC}_{6} \mathrm{H}_{4} \mathrm{CH}_{2} \mathrm{CrL}\left(\mathrm{H}_{2} \mathrm{O}\right)^{2+}\right]$ has a slope of 1.5 , implying a kinetic order of the reaction with respect to organochromium complex concentration of $3 / 2$. The plot of kobsd vs $\left[4-\mathrm{BrC}_{6} \mathrm{H}_{4} \mathrm{CH}_{2} \mathrm{CrL}\left(\mathrm{H}_{2} \mathrm{O}\right)^{2+}\right]^{3 / 2}$, shown in Figure II-7, defines a straight line through the origin; its slope gives the second-order rate constant $k_{10}=18.3 \mathrm{M}^{-1} \mathrm{~s}^{-1}$, as defined by eq II-10. 


$$
\frac{-\mathrm{d}\left[4-\mathrm{BrC}_{6} \mathrm{H}_{4} \mathrm{CH}_{2} \mathrm{CrL}\left(\mathrm{H}_{2} \mathrm{O}\right)^{2+}\right]}{\mathrm{dt}}=\mathrm{k}_{10}\left[\mathrm{I}_{2}\right]^{1 / 2}\left[4-\mathrm{BrC}_{6} \mathrm{H}_{4} \mathrm{CH}_{2} \mathrm{CrL}\left(\mathrm{H}_{2} \mathrm{O}\right)^{2+}\right]^{3 / 2}
$$

The chain mechanism proposed to account for the kinetic data is the following (with $\mathrm{p}-\mathrm{BrC}_{6} \mathrm{H}_{4} \mathrm{CH}_{2} \mathrm{CrL}\left(\mathrm{H}_{2} \mathrm{O}\right)^{2+}=\mathrm{RCrL}^{2+}$ ):

$$
\begin{aligned}
& \mathrm{RCrL}^{2+}+\mathrm{I}_{2} \longrightarrow \mathrm{RCrL}^{3+}+\mathrm{I}_{2}{ }^{-} \\
& \mathrm{RCrL}^{3+} \longrightarrow \mathrm{R}^{\cdot}+\mathrm{CrL}^{3+} \\
& \mathrm{R}^{\cdot}+\mathrm{I}_{2}+\mathrm{I}^{-} \longrightarrow \mathrm{RI}+\mathrm{I}_{2}^{\cdot} \\
& \mathrm{I}_{2}{ }^{-}+\mathrm{RCrL}^{2+} \longrightarrow \mathrm{RCrL}^{3+}+2 \mathrm{I}^{-} \\
& 2 \mathrm{I}_{2}{ }^{-} \longrightarrow \mathrm{I}_{3}^{-}+\mathrm{I}^{-}
\end{aligned}
$$

The resulting net reaction, assuming that the kinetic chain is long, is:

$$
\mathrm{RCrL}^{2+}+\mathrm{I}_{2} \longrightarrow \mathrm{PII}+\mathrm{CrL}^{3+}+\mathrm{I}^{-}
$$

With the steady-state approximation for the concentration of $\mathrm{I}_{2}{ }^{-}$and the aralkyl radical, the rate expression associated with the mechanisin given in eq II-11 to II-15 is the following: 


$$
-\mathrm{d}\left[\mathrm{RCrL}^{2+}\right] / \mathrm{dt}=\mathrm{k}_{1.4}\left(\mathrm{k}_{11} / \mathrm{k}_{15}\right)^{1 / 2}\left[\mathrm{RCrL}^{2+}\right]^{3 / 2}\left[\mathrm{I}_{2}\right]^{1 / 2}
$$

The predominant organic product of the reaction was determined to be RI by the method herein previously described, in which the reformation of RCrL $2+$ was observed upon addition of the chromium(II) macrocycle. Further confirmation came from the observed absorbance change at $352 \mathrm{~nm}$, which was consistent with the formation of RI in ea II-13, and not (for example) $\mathrm{ROH}$ Erom a reaction such as $\mathrm{R}^{\cdot}+\mathrm{I}_{2}+\mathrm{H}_{2} \mathrm{O} \longrightarrow \mathrm{ROH}+\mathrm{H}^{+}+\mathrm{I}_{2}{ }^{-}$.

The unique aspects of the mechanism are the oxidatively induced homolysis and the consequent participation of a chromium(IV) macrocycle in a kinetic chain. To our knowledge this is the first kinetically characterized reaction of $\mathrm{RM}$ in which the $\mathrm{RM}^{+}$species is a chain-carrying intermediate and homolysis of a transition metal-carbon bond is involved in a chain propagation process. Also, it should be noted that the mild oxidant $I_{2}$ reacts just sufficiently to initiate the kinetic chain (eq II11), and the much stronger oxidant $\mathrm{I}_{2}{ }^{-}$is required to cause chain propagation (eq II-14).

Exploratory experiments were conducted on the reactions between iodine and other benzylchromium macrocycles and on two secondary alkyl complexes. Fractional order kinetic behavior was also observed for $R=$ $\mathrm{PhCH}_{2}, 4-\mathrm{CH}_{3} \mathrm{C}_{6} \mathrm{H}_{4} \mathrm{CH}_{2}, 2-\mathrm{C}_{3} \mathrm{H}_{7}$, and $2-\mathrm{C}_{4} \mathrm{H}_{9}$. We surmise that each of these reactions also proceeds by a chain mechanism, most likely as in ey II-11. to II-15. Detailed measurements were not conducted in any of these cases, however. 
One notes the facility of the oxidation of $4-\mathrm{BrC}_{6} \mathrm{H}_{4} \mathrm{CH}_{2} \mathrm{CrL}\left(\mathrm{H}_{2} \mathrm{O}\right)^{2+}$ to the corresponding $\mathrm{Cr}$ (IV) complex, as shown in eq II-11. Independent studies show that $\mathrm{RCrL}\left(\mathrm{H}_{2} \mathrm{O}\right)^{2+}$ complexes, with $\mathrm{R}=$ aralkyl and secondary alkyl, are readily oxidized by various kinds of weak oxidants (e.g., $\mathrm{Fe}^{3+}, \mathrm{ABTS}^{-}-, 20$ and $\left.\mathrm{CoIII}_{(\text {tetraeneN }}{ }^{+}\right)$. These studies will be reported elsewhere. 21

\section{Bimolecular Electrophilic Substitution Reaction between}

4- $\mathrm{BrC}_{6} \mathrm{H}_{4} \mathrm{CH}_{2} \mathrm{CrL}\left(\mathrm{H}_{2} \mathrm{O}\right)^{2+}$ and Iodine. All indications of a chain reaction disappear when the reaction is conducted under different concentration conditions. Evidently a new pathway becomes important. This occurs when the bromobenzyl chromium complex is used as the limiting reagent at sufficiently low concentrations $\left(\leq 10^{-5} \mathrm{M}\right)$. Under these conditions the rate law appears to be first-order with respect to each reagent. The two pathways operate in parallel, and the complete rate law is

$$
-d\left[\operatorname{RCrL}^{2+}\right] / d t=k_{I_{2}}\left[I_{2}\right]\left\lfloor\operatorname{RCrL}^{2+}\right]+k_{10}\left[I_{2}\right]^{1 / 2}\left[\mathrm{RCrL}^{2+}\right]^{3 / 2}
$$

The relative importance of the two terms is governed mainly by the concentration of the organochromium complex. Experiments to evaluate the $\mathrm{k}_{\mathrm{I}_{2}}$ term were conducted in the following concentration ranges:

$\left[\mathrm{RCrL}^{2+}\right]_{0}=1.9 \times 10^{-5}$ and $\left[\mathrm{I}_{2}\right]=(0.33-1.1) \times 10^{-3} \mathrm{M}$. The kinetic data fit fairly well to pseudo-first-order kinetics, but not perfectly, since the fractional-order term is not entirely negligible. The value of $k_{I_{2}}$ was estimated from the iodine variation and has the value of $9.5 \mathrm{M}^{-1}$ 
$s^{-1}$. The product analysis shows that RI is the only organic product both in the absence and in the presence of $\mathrm{O}_{2}$. This result confirms the nature of the observed bimolecular process being an electrophilic substitution. The relative importance of the $k_{10}$ term in eq II-18 increases as the chromium concentration increases. At high (> $\left.10^{-4} \mathrm{M}\right)$ concentrations the chain pathway becomes predominant.

It is noted that the complexes with primary alkyl groups behave differently toward iodine compared to those with aralkyl and secondary alkyl groups. This difference is related to the ease of oxidation of a given class of these complexes and by the different stabilities of the corresponding free radicals. Aralkyl and secondary alkyl groups are more electron donating than primary alkyl groups, resulting in more oxidizable organochromium complexes. Also, the greater stability of secondary and aralkyl radicals compared to primary alkyls makes the homolysis of the organochromium(IV) macrocycle (eq II-12) occur more readily. Both of these factors facilitate the chain process for the secondary alkyl and aralkyl chromium macrocycles, and disfavor that for the primary alkyl complexes. 
Table II-1. Crystallographic Data for $\left[4-\mathrm{BrC}_{6} \mathrm{H}_{4} \mathrm{CH}_{2} \mathrm{CrL}\left(\mathrm{H}_{2} \mathrm{O}\right)\right]\left(\mathrm{ClO}_{4}\right)_{2} \cdot \mathrm{THF}$

\section{Formula}

Formula weight

Space group

a, $\AA$

b, A

c, $\AA$

$B,{ }^{\circ}$

$\mathrm{V}, \AA^{3}$

Z

$\mathrm{d}_{\mathrm{calc}}, \mathrm{g} / \mathrm{cm}^{3}$

Crystal size, mm

$\mu\left(\right.$ MoK. $\left._{\alpha}\right), \mathrm{cm}^{-1}$

Data collection instrument

Radiation (monochromated in incident beam)

orientation reflections, number, range (20)

Temperature, ${ }^{\circ} \mathrm{C}$

Scan method

Data collection range, $2 \Theta$ deg

No. of unique data, total: with $\mathrm{F}_{\mathrm{O}}^{2}>2.5 \sigma\left(\mathrm{F}_{\mathrm{O}}^{2}\right)$ :

Number of parameters refined

Trans. factors, max, min (psi-scans) $\mathrm{R}^{\mathrm{a}}$

$R_{W} b$

Quality-of-Eit inticator ${ }^{c}$

Largest shift/esd, final cycle

Largest peak, $e / \AA^{3}$
$\mathrm{CrBrCl}_{2} \mathrm{O}_{10} \mathrm{~N}_{4} \mathrm{C}_{22} \mathrm{H}_{42}$

725.41

$\mathrm{P}_{\mathrm{j}} / \mathrm{C}(\mathrm{no}, 14)$

$11.683(3)$

$8.816(3)$

$29.959(8)$

$96.29(1)$

$3067(3)$

4

1.571

$0.30 \times 0.14 \times 0.13$

18.84

Enraf-Nonius CADl

$\operatorname{MoK}_{\alpha}(\lambda=0.71073 A)$

$25,14^{\circ}<2 \theta<32^{\circ}$

$22 \pm 1$

$\theta-2 \theta$

$0-45$

4018

1293

163

$1.00,0.93$

0.0806

0.0943

1.66

0.15

0.69

$$
\begin{aligned}
& a_{R}=E|| F_{0}|-| F_{C}|| / \Sigma\left|F_{0}\right| \text {. } \\
& b_{R_{W}}=\left[\sum w\left(\left|F_{O}\right|-\left|F_{C}\right|\right)^{2} /\left[w\left|F_{O}\right|^{2}\right]^{1 / 2} ; w=1 /\left[\sigma^{2}\left(\left|F_{O}\right|\right)+0.001\left|F_{o}\right|^{2}\right]\right. \text {. }
\end{aligned}
$$

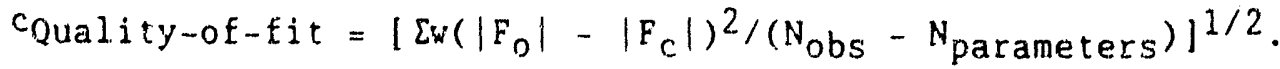


Table II-2. Bond Distances $(\AA)$

\begin{tabular}{|c|c|c|c|c|c|}
\hline $\begin{array}{l}\text { Atom } 1 \\
==-===\end{array}$ & $\begin{array}{l}\text { Atom } 2 \\
==m===\end{array}$ & $\begin{array}{l}\text { Distance } \\
==m=m=m=\end{array}$ & $\begin{array}{l}\text { Atom } 1 \\
==m=m=\end{array}$ & $\begin{array}{l}\text { Atom } 2 \\
===m=x=\end{array}$ & $\begin{array}{l}\text { Distance } \\
=m=m=m=\end{array}$ \\
\hline Cr & $O(1)$ & $2.13(1)$ & $c(3)$ & $c(4)$ & $1.48(3)$ \\
\hline$C r$ & $N(1)$ & $2.11(2)$ & $C(5)$ & $c(6)$ & $1.52(3)$ \\
\hline $\mathrm{Cr}$ & $N(2)$ & $2.08(2)$ & $c(6)$ & $c(7)$ & $1.56(3)$ \\
\hline$C r$ & $N(3)$ & $2.12(2)$ & $c(8)$ & $c(9)$ & $1.44(4)$ \\
\hline$C r$ & $N(4)$ & $2.08(2)$ & $C(9)$ & $c(10)$ & $1.60(5)$ \\
\hline$C r$ & $c(1)$ & $2.14(2)$ & $c(11)$ & $c(12)$ & $1.56(4)$ \\
\hline$B I$ & $c(24)$ & $1.89(1)$ & $c(21)$ & $c(22)$ & $1.39(2)$ \\
\hline$N(1)$ & $c(2)$ & $1.52(3)$ & $c(21)$ & $c(26)$ & $1.39(2)$ \\
\hline$N(1)$ & $c(12)$ & $1.45(3)$ & $C(22)$ & $c(23)$ & $1.40(1)$ \\
\hline$N(2)$ & $c(4)$ & $1.50(3)$ & $C(23)$ & $c(24)$ & $1.39(2)$ \\
\hline$N(2)$ & $c(5)$ & $1.45(3)$ & $C(24)$ & $C(25)$ & $1.39(2)$ \\
\hline is ( 3$)$ & $c(7)$ & $1.36(3)$ & $c(25)$ & $c(26)$ & $1.39(1)$ \\
\hline$N(3)$ & $c(8)$ & $1.53(3)$ & $0(10)$ & $c(31)$ & $1.43(3)$ \\
\hline$N(4)$ & $c(10)$ & $1.24(5)$ & $O(10)$ & $c(34)$ & $1.45(3)$ \\
\hline$N(4)$ & $C(11)$ & $1.82(4)$ & $C(31)$ & $c(32)$ & $2.46(4)$ \\
\hline$C(1)$ & $c(21)$ & $1.48(2)$ & $c(32)$ & $c(33)$ & $1.43(5)$ \\
\hline$C(2)$ & $c(3)$ & $1.50(3)$ & $C(33)$ & $c(34)$ & $1.43(5)$ \\
\hline
\end{tabular}

Numbers in parentheses are estimated standard deviations in the least significant digits. 


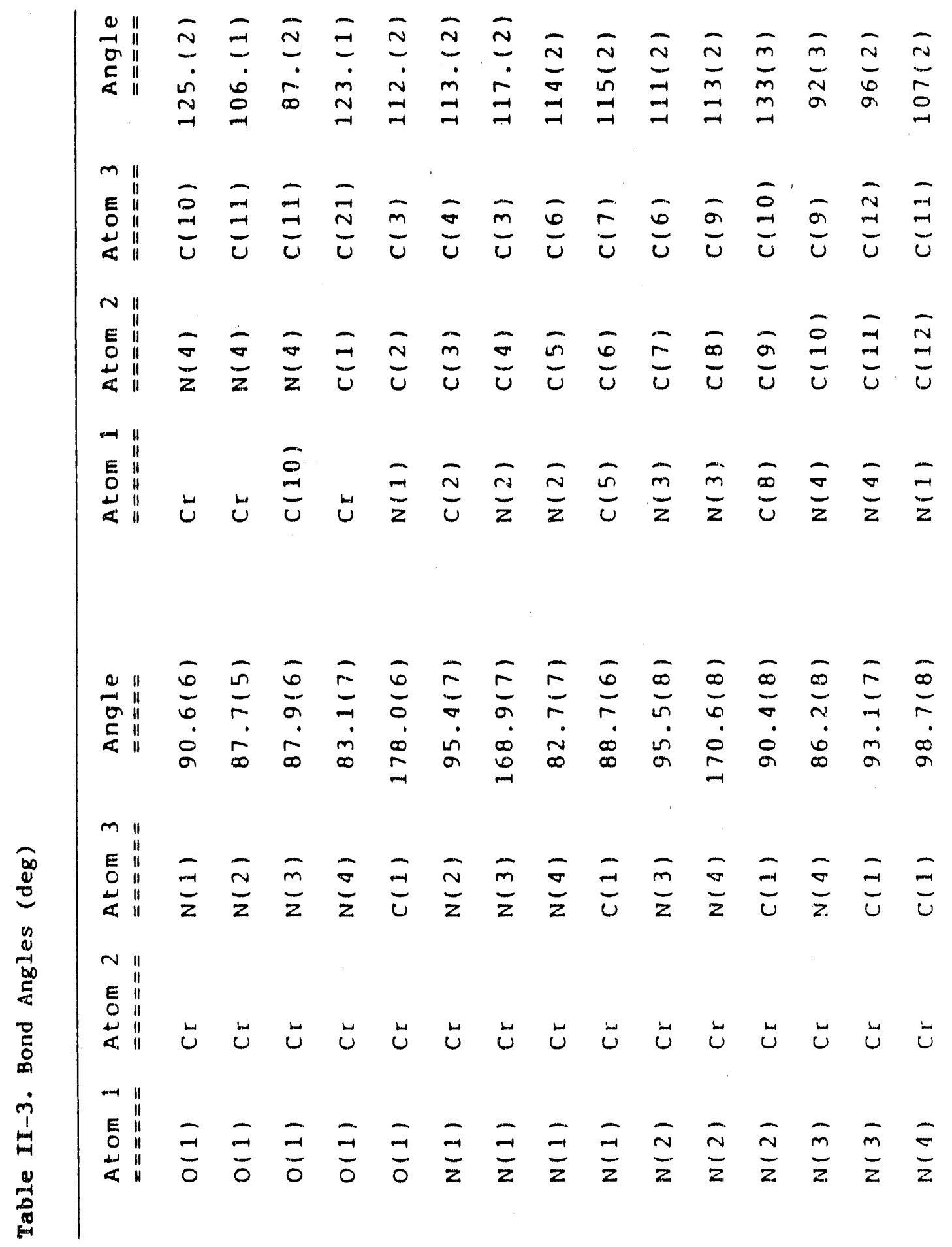




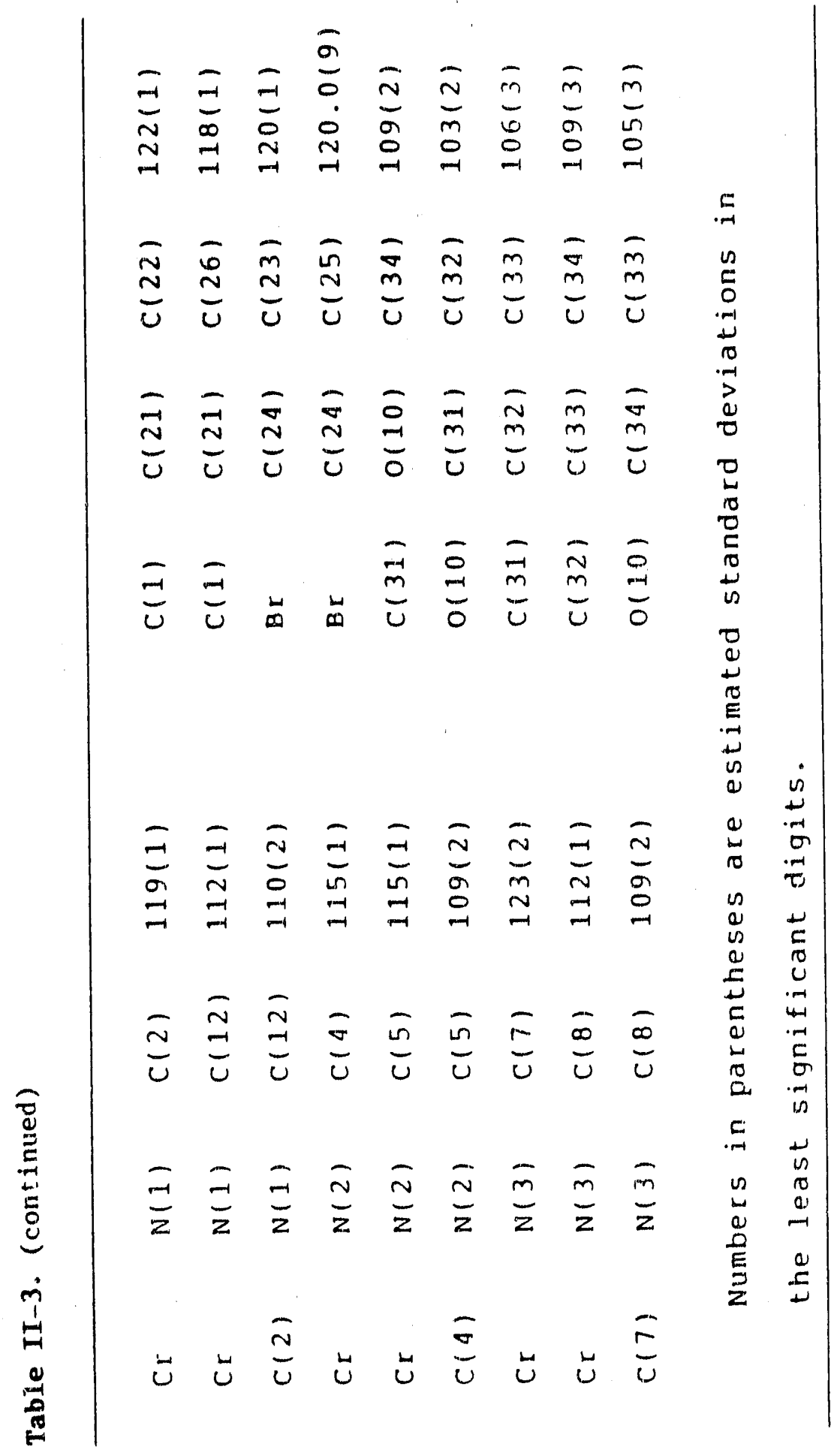


Table II-4. Second-Order Rate Constants for the Electrophilic Cleavage of Chromium-Carbon Bonds of $\mathrm{RCr}\left([15] \mathrm{aneN}_{4}\right) \mathrm{H}_{2} \mathrm{O}^{2+}$ by Iodine $\mathrm{a}^{\mathrm{a}}$

\begin{tabular}{ll}
\hline \multicolumn{1}{c}{$\mathrm{k} / \mathrm{M}^{-1} \mathrm{~s}^{-1}$} \\
\hline $\mathrm{CH}_{3}$ & $4.7 \times 10^{3}$ \\
$\mathrm{C}_{2} \mathrm{H}_{5}$ & $8.1 \times 10^{1}$ \\
$\mathrm{n}-\mathrm{C}_{3} \mathrm{H}_{7}$ & $1.2 \times 10^{1}$ \\
$n-\mathrm{C}_{4} \mathrm{H}_{9}$ & $8.9 \times 10^{0}$ \\
$4-\mathrm{BrC}_{6} \mathrm{H}_{4} \mathrm{CH}_{2}$ & $\left(9.5 \times 10^{0}\right)^{\mathrm{b}}$ \\
\hline
\end{tabular}

a In aqueous solution at $25.0^{\circ} \mathrm{C}$; ionic strength $0.2 \mathrm{M}\left(\mathrm{HClO}_{4}+\right.$ $\left.\mathrm{NaClO}_{4}\right) \cdot\left[\mathrm{H}^{+}\right]=0.010 \mathrm{M}$.

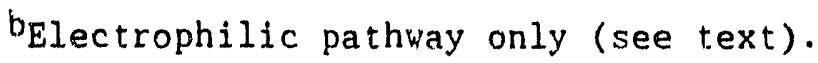




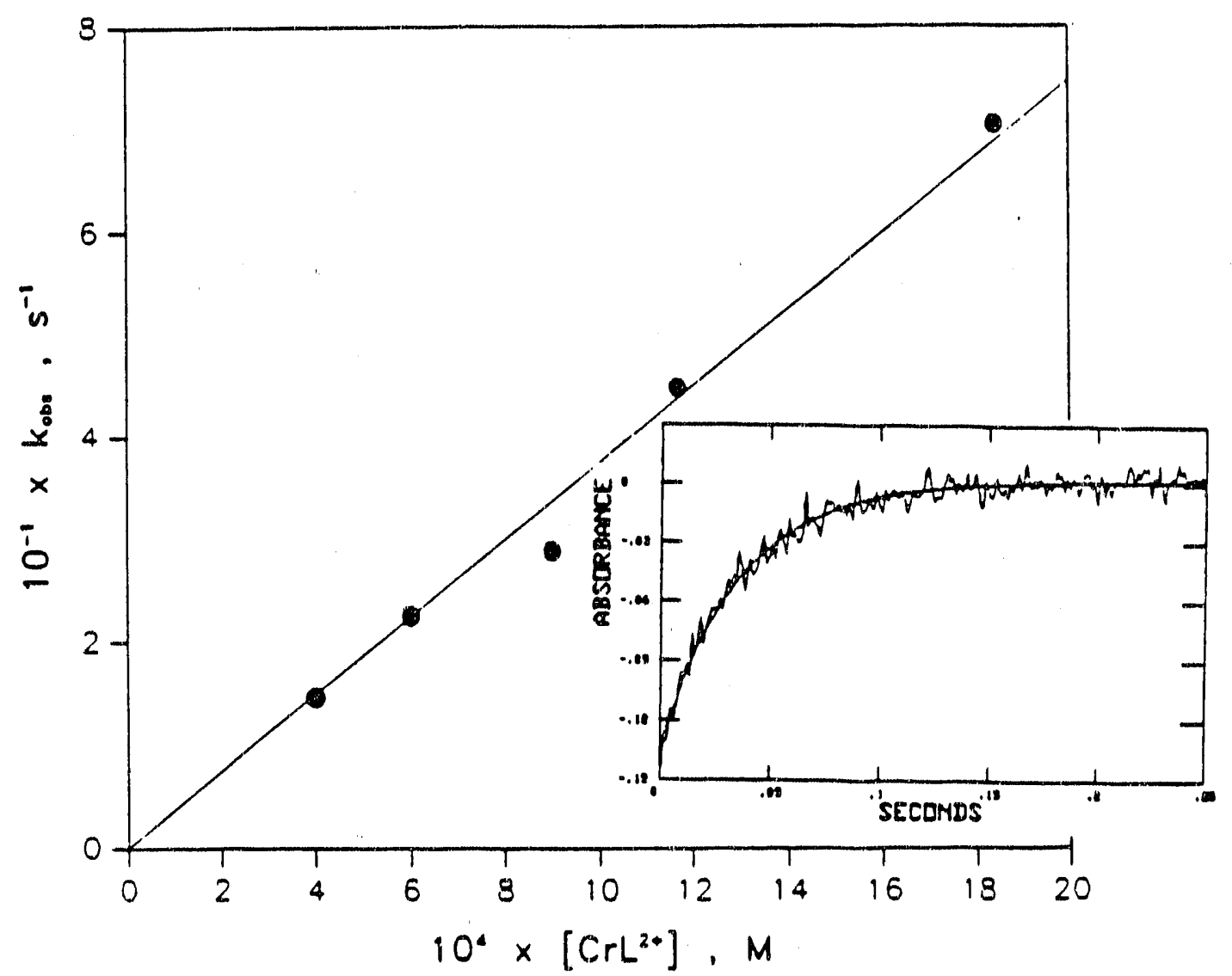

Pigure II-1. Plot for the reaction of $\mathrm{CrL}\left(\mathrm{H}_{2} \mathrm{O}\right)^{2+}$ with $4-\mathrm{BrC}_{6} \mathrm{H}_{4} \mathrm{CH}_{2} \mathrm{Br}$ showing the variation of the pseudo-first-order rate constant kobsd with the concentration of the chromium(II) macrocycle. The inset shows a stopped-flow kinetic trace for a run with $\left[\mathrm{CrL}^{2+}\right]_{0}=9.0 \times 10^{-4} \mathrm{M}$ and $[\mathrm{RBr}]=8.8 \times$ $10^{-6} \mathrm{M}$ 

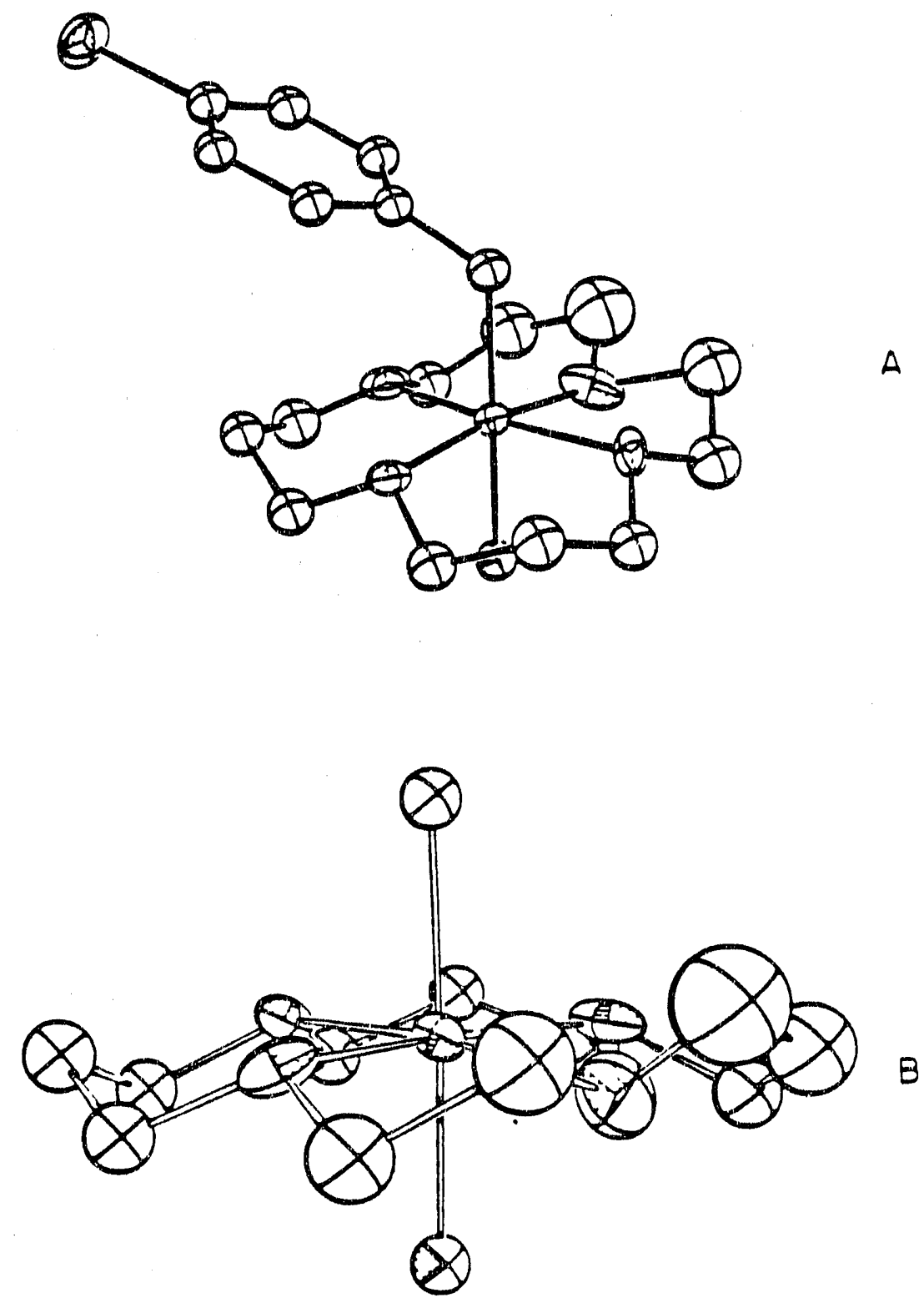

Figure II-2. ORTEP diagram of the bromobenzyl chromium macrocycle showing (a) the molecular structure of the cation and (b) the primary coordination shell of the chromium, with emphasis of the distinction between sides $A$ (above) and $B$ (below) 


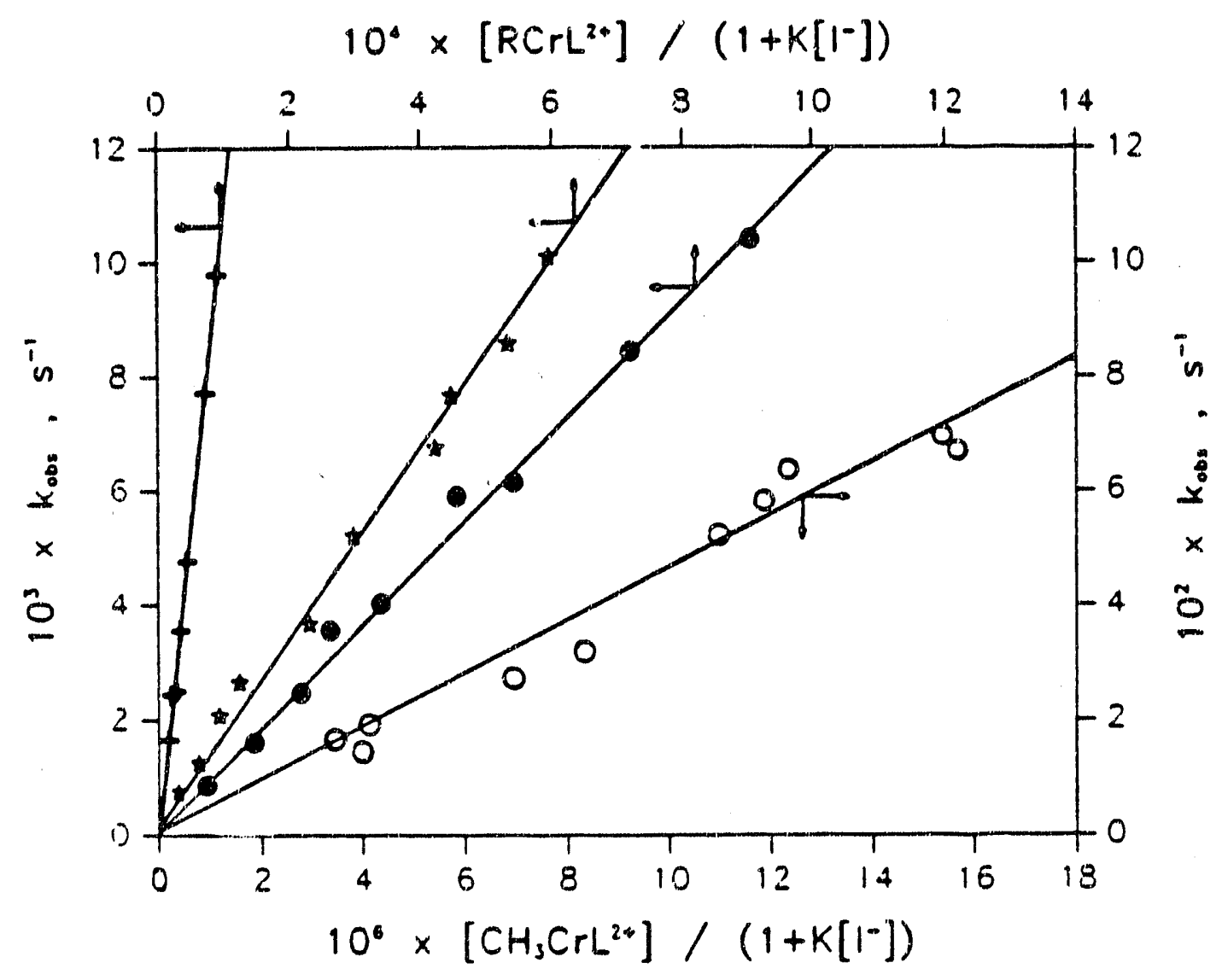

Figure II-3. Plots of kinetic data for the reaction of alkylchromium macrocycles $\left(\mathrm{R}=\mathrm{Me}, 0 ; \mathrm{C}_{2} \mathrm{H}_{5},+; 1-\mathrm{C}_{3} \mathrm{H}_{7}, * ; 1-\mathrm{C}_{4} \mathrm{H}_{9}\right.$, ) with iodine in acidic solution showing the effects of the variation of the alkylchromium and iodide concentrations. $\left[\mathrm{RCrL}\left(\mathrm{H}_{2} \mathrm{O}\right)^{2+}\right]_{0}=(0.02-2.8) \times 10^{-3} \mathrm{M} ;\left[\mathrm{I}^{-}\right]_{0}=(1.0-$ $8.0) \times 10^{-3} \mathrm{M} ;\left[\mathrm{I}_{2}\right]_{0}=(0.39-2.2) \times 10^{-5} \mathrm{M}$ 


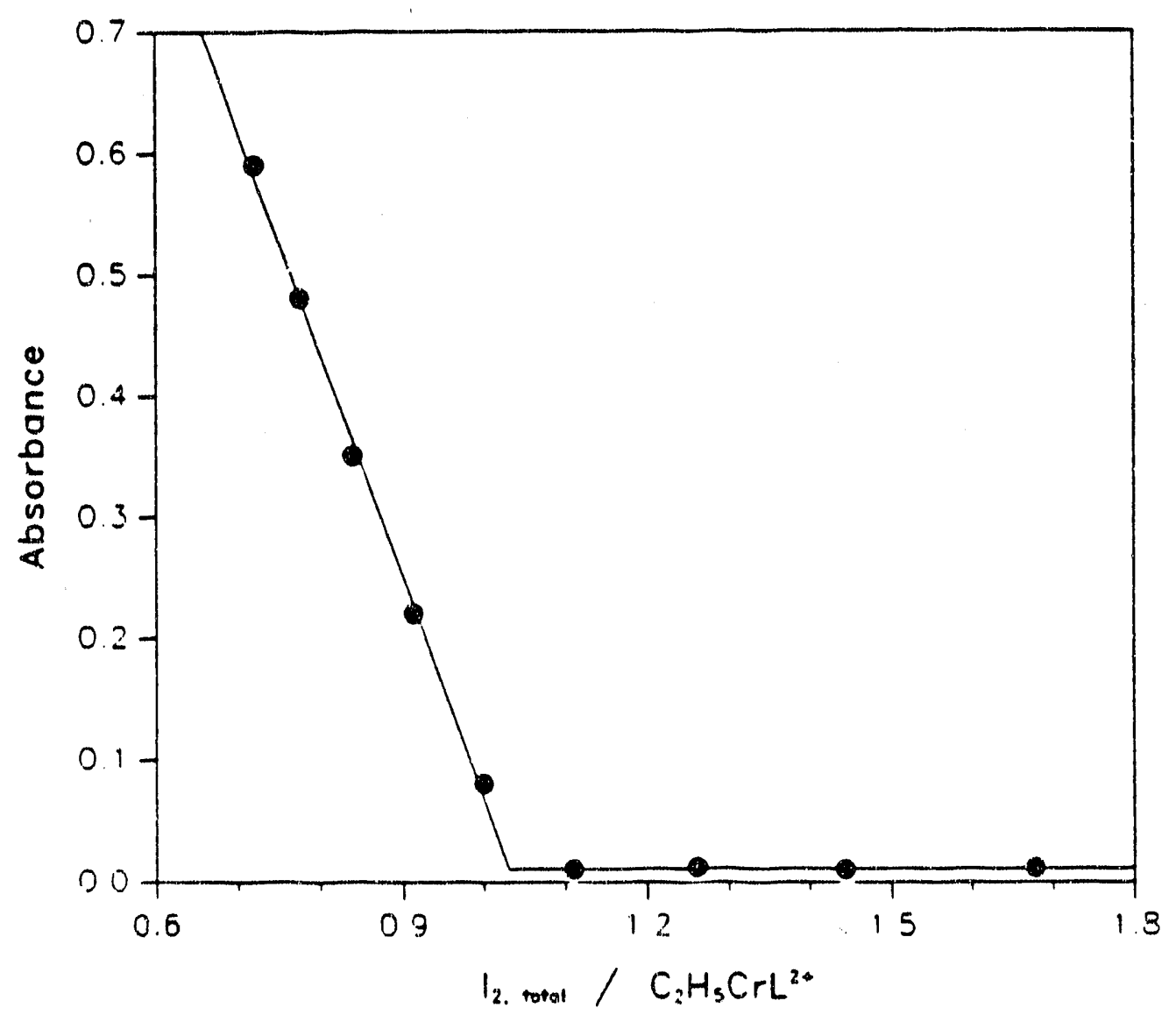

Bigure II-4. The titration of the ethylchromium macrocycle with iodine showing the endpoint at a $1: 1$ ratio 


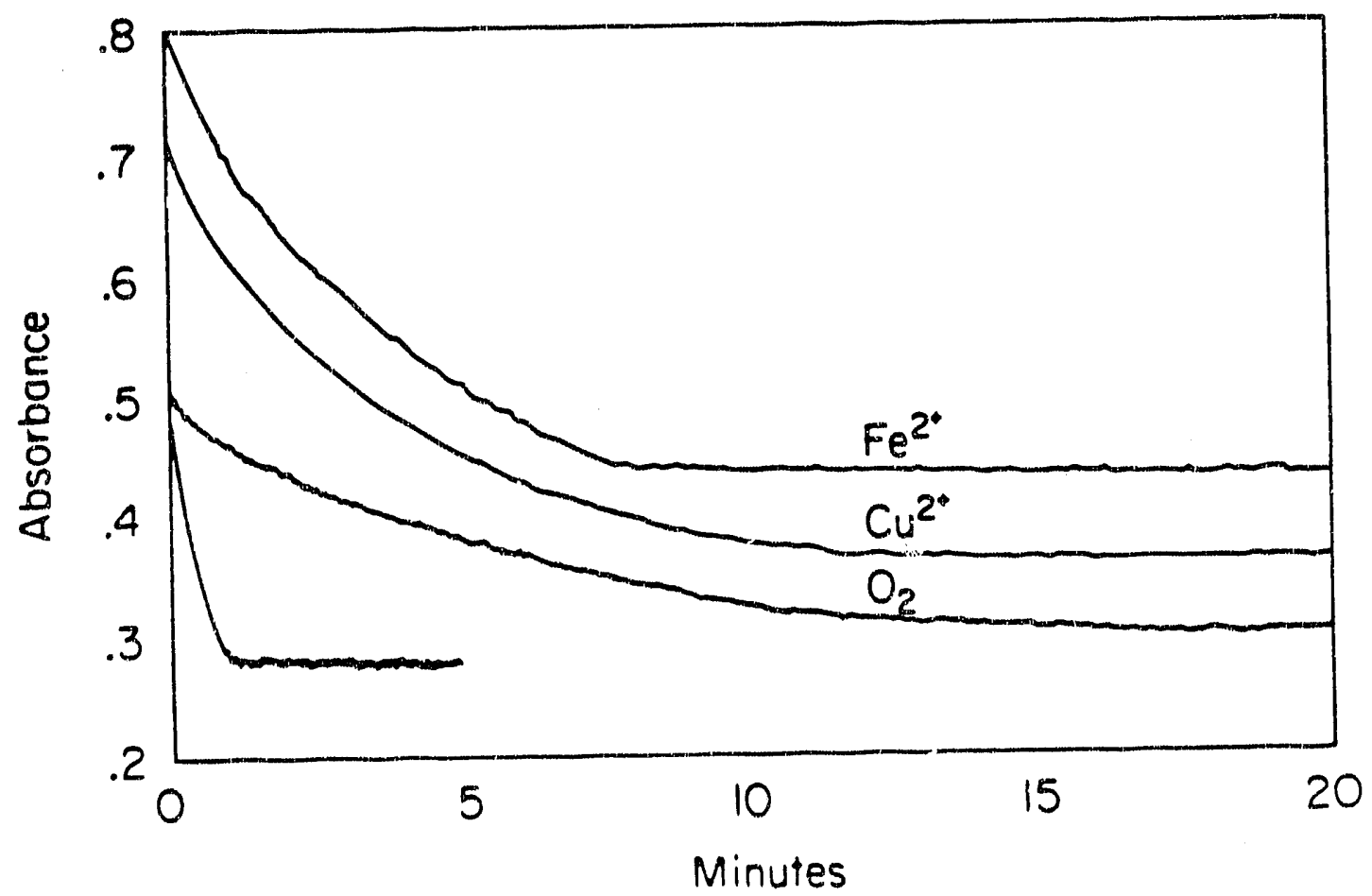

Pigure II-5. Kinetic traces for the reaction of $I_{2}\left(2.0 \times 10^{-5} \mathrm{M}\right)$ and $4-\mathrm{BrC}_{6} \mathrm{H}_{4} \mathrm{CH}_{2} \mathrm{CrL}\left(\mathrm{H}_{2} \mathrm{O}\right)^{2+}\left(1.7 \times 10^{-4} \mathrm{M}\right)$. The unafrected chain reaction is shown along with reactions that are inhibited by $\mathrm{O}_{2}\left(1.3 \times 10^{-3} \mathrm{M}\right), \mathrm{Cu}^{2}+\left(4.0 \times 10^{-3} \mathrm{M}\right)$, and $\mathrm{Fe}^{2+}\left(3.7 \times 10^{-4} \mathrm{M}\right)$. Each run contained $4.0 \times 10^{-3} \mathrm{M} \mathrm{I}^{-}$ 


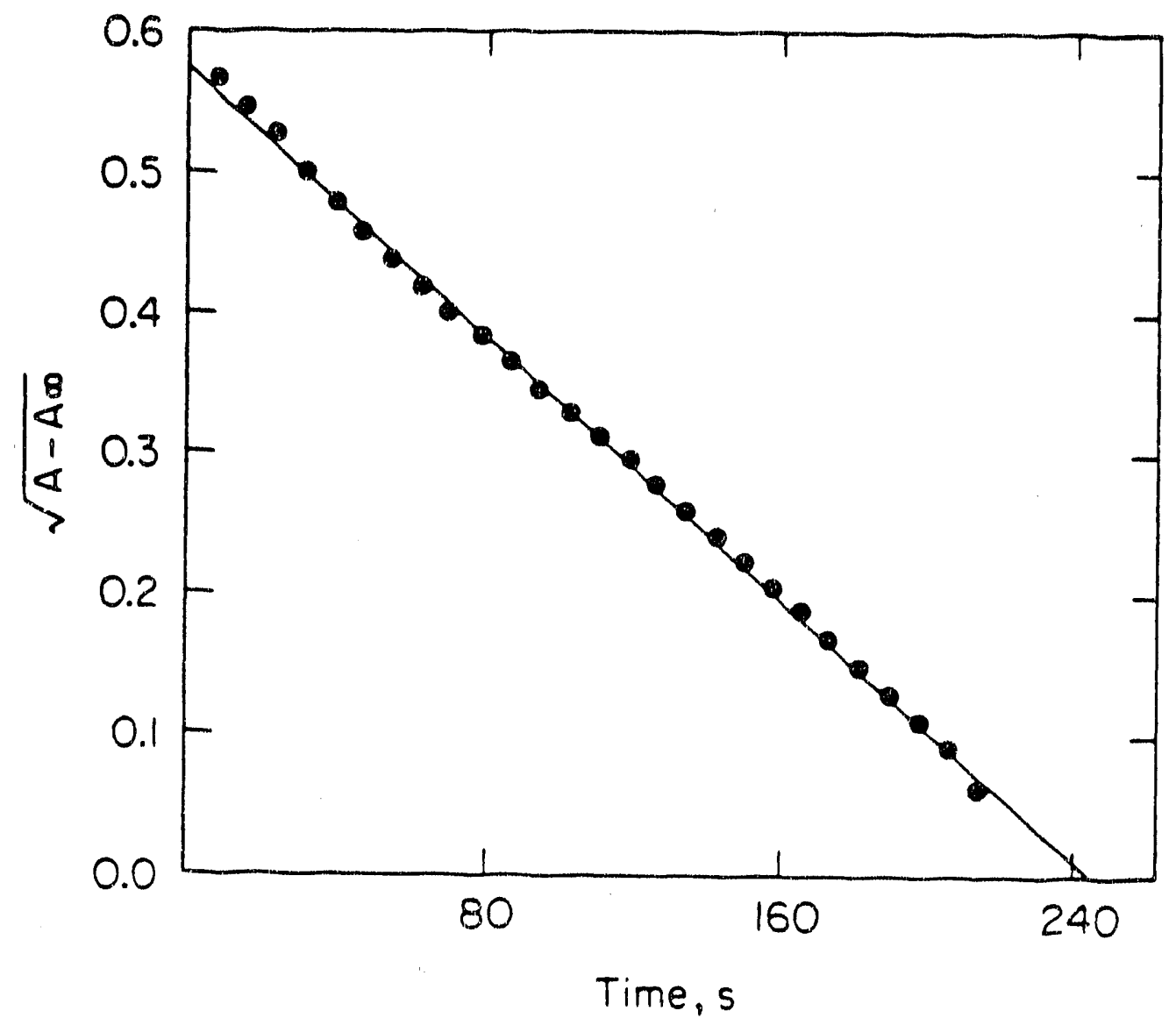

Figure II-6. Plot showing the fit to pseudo-half-order kinetics in a reaction between $I_{2}\left(2.0 \times 10^{-5} \mathrm{M}\right)$ and $4-\mathrm{BrC}_{6} \mathrm{H}_{4} \mathrm{CH}_{2} \mathrm{CrL}\left(\mathrm{H}_{2} \mathrm{O}\right)^{2+}\left(1.6 \times 10^{-4} \mathrm{M}\right)$ in the presence of $\mathrm{I}^{-}$ $\left(4.0 \times 10^{-3} \mathrm{M}\right)$ 


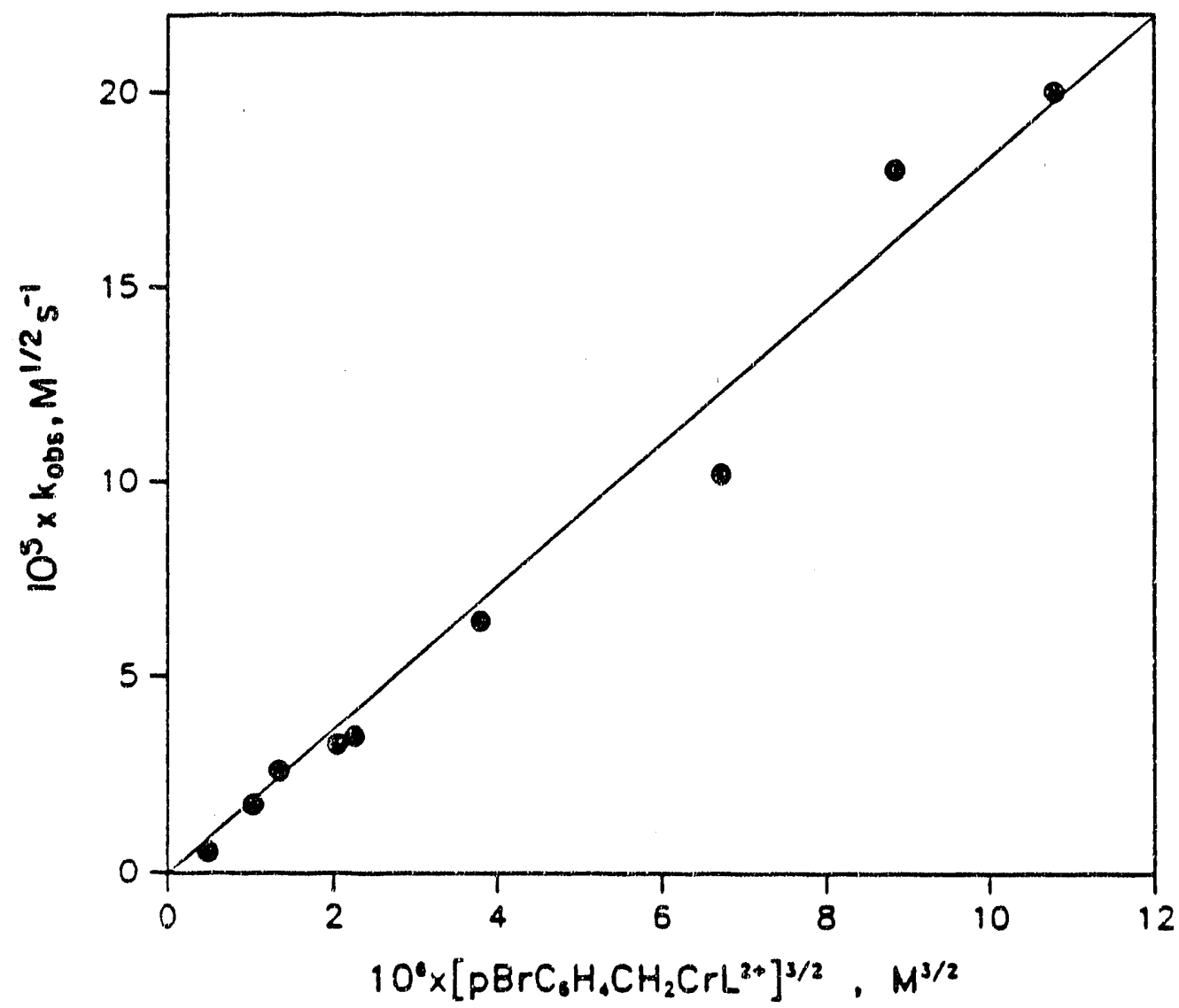

Pigure II-7. Plot illustrating the varjation of the half-order rate constant with the $3 / 2$-power of the concentration of the bromobenzyl macrocycle. $\left(\left[I_{2}\right]=2 \times 10^{-5} \mathrm{M},\left[\mathrm{I}^{-}\right]=2 \times\right.$ $\left.10^{-3} \mathrm{M}\right)$ 


\section{REFERENCES}

(1) Kochi, J. K. "Organometallic Mechanisms and Catalysis", Academic Press, New York, 1978, Chapter 18.

(2) (a) Espenson, J. H.; Williams, D. A. J. Am. Chem. Soc. 1974, 96, 1008; (b) Chang, J. C. ; Espenson, J. H. Chem. Commun. 1974, 233; (c) Espenson, J. H.; Samuels, G. J. J. Organomet. Chem. 1976, 113, 143.

(3) (a) Halpern, J.; Topich, J.; Zamaraev, K. I. Inorg. Chim. Acta 1976, 20, L21; (b) Topich, J.; Halpern, J. Inorg. Chem. 1979, 18, 1339 .

(4) (a) Dreos, R.; Tauzher, G.; Marsich, N.; Costa, G. J. Organomet. Chem. 1975, 92, 227; (b) Dreos-Garlatti, R.; Tauzher, G.; Costa, G. J. Organomet. Chem. 1977, 139, 179; (c) Dreos-Garlatti, R.; Tauzher, G.; Costa, G. J. Organomet. Chem. 1979, 182, 409.

(5) (a) Okamoto, T.; Goto, M.; Ok.a, S. Inorg. Chem. 1981, 20, 899;

(b) Fukuzumi, S.; Ishikawa, K.; Tanaka, T. Chem. Lett. 1986, 1801; (c) Fanchiang, Y.-T. Organometallics 1985, 4, 1515; (d)

Fukuzumi, S.; Goto, T.; Ishikawa, K.; Tanaka, T. J. Chem. Soc. Chern. Commun. 1989, 260.

(6) Toscano, P. J.; Barren, E.; Seligson, A. L. Organometallics $1989,8,2085$.

(7) Fukuzumi, S.; Nishizawa, N.; Tanaka, T. Bull. Chem. Soc. Jpn. 1983, 56, 709 .

(8) Samuels, G. J.; Espenson, J. H. Inorg. Chem. 1979, 18, 2587. $[15]_{\text {aneN }_{4}}=1,4,8,12$-tetraazacyclopentadecane. 
(9) Samuels, G. J.; Espenson, J. H. Inorg. Chem. 1980, 19, 233.

(10) Holah, D. G.; Fackler, J. P., Jr.; Inorg. Synth. 1969, 10, 26.

(11) Awtry, A. D.; Connick, R. E. J. Am. Chem. Soc. 1965, 87, 5026.

(12) Shi, S.; Espenson, J. H.; Bakac, A. Inorg. Chem. 1990, 29, 4318.

(13) Ogino, H.; Shoji, M.; Abe, Y.; Shimura, M.; Shimoi, M. Inorg. Chem. $1987,26,2592$.

(14) Abe, Y.; Ogino, H. Bull. Chem. Soc. Jpn. 1989, 62, 56.

(15) Daly, J. J.; Sanz, F.; Sneeden, R. P. A.; Zeiss, H. H. J. Chem. Soc. Dalton Trans. 1973,1497 . We appreciate a referee calling this paper to our attention.

(16) Samuels, G. J. Ph.D. Thesis, Iowa State University, 1979.

(1.7) Rabani, J.; Pick, M.; Simic, M. J. Phys. Chem. 1974, 78, 1049.

(18) (a) Buxton, G. V.; Green, J. C. J. Chem. Soc., Faraday Trans. I 1978, 74, 697; (b) Scaiano, J. C.; Leigh, W. J.; Ferraudi, G. Can. J. Chem. 1984, 62, 2355.

(19) Laurence, G. S.; Thornton, A. J. J. Chem. Soc., Dalton Trans. 1974, 1142 .

(20) $A B^{\prime} \mathrm{SS}^{2-}=2,2^{\prime}$-azino-bis(3-ethylbenzthiazoline-6-sulfonate ion.

(21) Shi, S.; Bakac, A.; Espenson, J.H. (Subnitted for publication), or see Part IV of this thesis. 
PART III. REACTIVITY OF ORGANOCHROMIUM COMPLEXES TOHARD INORGANIC RADICALS. A PULSE RADIOLYSIS STUDY 


\section{INTRODUCTION}

In a previous paper ${ }^{1}$ of this series we discovered a chain reaction between organochromium(III) macrocyclic complexes $\mathrm{RCrL}\left(\mathrm{H}_{2} \mathrm{O}\right)^{2+}$ and lodine where an oxidation step of $\mathrm{RCrL}\left(\mathrm{H}_{2} \mathrm{O}\right)^{2+}$ by a dilodide radical anion $\mathrm{I}_{2}{ }^{--}$ served as one of the chain propagation steps.

$$
\mathrm{RCrL}\left(\mathrm{H}_{2} \mathrm{O}\right)^{2+}+\mathrm{I}_{2}{ }^{-} \rightarrow \mathrm{RCrL}\left(\mathrm{H}_{2} \mathrm{O}\right)^{3+}+2 \mathrm{I}^{-}
$$

This study seeks independent evidence of the oxidation of $\operatorname{RCrL}\left(\mathrm{H}_{2} \mathrm{O}\right)^{2+}$ by dihalogen radical anions. It concerns the rate of the oxidation as well as the reaction mechanism. 


\section{EXPERIMENTAL SECTION}

Reagents. Organochromium(III) complexes were prepared according to the known methods. 2,3 The concentrations of various organochromium(III) complexes were measured spectrophotometrically,1-3 Sodium halides and sodium thiocyanate solutions were prepared from commercial A.R. grade solids and triply distilled water. All solutions were deaerated and saturated with $\mathrm{N}_{2} \mathrm{O}$ for the purpose of pulse radiolysis.

Pulse Radiolysis. The oxidizing reagents $\mathrm{X}_{2} \cdot-(\mathrm{X}=\mathrm{I}, \mathrm{Br}, \mathrm{SCN})$ were generated from the $\mathrm{O}_{2}$-free, $\mathrm{N}_{2} \mathrm{O}$-saturated aqueous solution of sodium halides or sodium thiocyanate. 4

The pertinent reactions are as follows,

$$
\begin{aligned}
& \mathrm{H}_{2} \mathrm{O}+\mathrm{e}^{-} \text {(pulse) } \rightarrow \mathrm{e}_{\mathrm{aq}}^{-}, \mathrm{HO}^{\cdot}, \mathrm{H}^{\cdot}, \mathrm{H}^{+}, \mathrm{H}_{2} \mathrm{O}_{2} \\
& \mathrm{~N}_{2} \mathrm{O}+\mathrm{eaq}^{-}+\mathrm{H}^{+} \rightarrow \mathrm{HO}^{\cdot}+\mathrm{N}_{2} \\
& \mathrm{HO}^{-}+2 \mathrm{X}^{-} \rightarrow \mathrm{OH}^{-}+\mathrm{X}_{2} \cdot- \\
& \mathrm{X}_{2}{ }^{-}+\mathrm{RCrL}\left(\mathrm{H}_{2} \mathrm{O}^{2+} \rightarrow 2 \mathrm{X}^{-}+\mathrm{RCrL}\left(\mathrm{H}_{2} \mathrm{O}\right)^{3+}\right.
\end{aligned}
$$

The acidity of $10^{-4} \mathrm{M}$ was used so that $e_{a q}$ - reacts as in eq III-3, not with $\mathrm{H}_{3} \mathrm{O}^{+}$. An ionic strength of $0.1 \mathrm{M}$ was realized by addition of $\mathrm{NaClO}_{4}$. No thermal reaction was found between $\mathrm{N}_{2} \mathrm{O}$ and organochromium(III) complexes. Pulse radiolysis experiments were performed at Argonne National Laboratory with an electron beam of $15-\mathrm{MeV}$ and 4-ns pulse length. The reaction were followed by monitoring the disappearance of $\mathrm{X}_{2}{ }^{-}$- at various wave lengths (e.g., 340,370, 400, 475 
$\mathrm{nm})$ 4-8 A $1-\mathrm{cm}$ or a 2-cm cell was used depending on the concentration of radical anions and organochromium complexes to obtain a sizable change of optical density and at the same time minimize the background absorbance. Pseudo-first-order rate constants were calculated from the observed kinetic traces by using a nonlinear least-squares data fitting program. 


\section{RESULTS AND DISCUSSION}

The reactions were conducted under conditions with concentrations of organochromium(III) complexes $\operatorname{RCrL}\left(\mathrm{H}_{2} \mathrm{O}\right)^{2+}$ in large excess over those of oxidants $X_{2} \cdot-$, so that the pseudo-first-order rate constant ( $k_{o b s}$ ) varied linearly with $\left[\mathrm{RCrL}\left(\mathrm{H}_{2} \mathrm{O}\right)^{2+}\right]$. With the concentration of organochromium(III) complexes typically controlled at $10^{-4} \sim 10^{-3} \mathrm{M}$, the pseudo-first-order rate constants observed range from $9 \times 10^{3}$ to $8 \times 10^{4}$ $\mathrm{s}^{-1}$ consistent with the role $\mathrm{I}_{2}{ }^{-}$- played in the chain reaction with $\operatorname{RCrl}\left(\mathrm{H}_{2} \mathrm{O}\right)^{2+}$.

The pseudo-first-order rate constants obtained are independent of the wavelength of observation. The influence of the second order radical self reaction is often significant only to the first several percent of kinetic data which were obtained immediately after the pulse. Generally speaking, the contribution of the radical self-reaction to the total optical absorbance change is normally small and constant and can be corrected by blank experiments conducted under identical conditions but in the absence of $\operatorname{RCrL}\left(\mathrm{H}_{2} \mathrm{O}\right)^{2+}$. Good quality of data fitting was obtained in most of the cases. A typical plot is shown in Figure III-1.

A linear relationship between $k_{o b s}$ and $\left[\operatorname{RCrL}\left(\mathrm{H}_{2} \mathrm{O}\right)^{2+}\right]$ was observed throughout the concentration range used, as depicted in Pigure III-2. The second-order rate constants are listed in Table III-1 along with other pertinent values.

The second-order rate constants increase as the oxidizing ability of the oxidants. But the change in rate constants for a given 
$\mathrm{Br}_{2}{ }^{-}$is much smaller than one would expect based on calculations according to Marcus theory. ${ }^{9}$ Similarly, for a chosen radical anion, the change in the rate constants along the series of alkyl groups is also smaller than that observed with $\mathrm{TrCl}_{6}{ }^{2-}$ as an oxidant (Tabie III-1). When $\mathrm{IrCl}_{6} 2$ - was used, the observed ratio of rate constant of $4-\mathrm{CH}_{3} \mathrm{C}_{6} \mathrm{H}_{4} \mathrm{CH}_{2} \mathrm{CrL}\left(\mathrm{H}_{2} \mathrm{O}\right)^{2+}$ over that of $4-\mathrm{BrC}_{6} \mathrm{H}_{4} \mathrm{CH}_{2} \mathrm{CrL}\left(\mathrm{H}_{2} \mathrm{O}\right)^{2+}$ is ca. 40 whereas in $\mathrm{Br}_{2} \cdot-$ or $(\mathrm{SCN})_{2}-$ series, the ratio is only ca. 2. More pronouncedly, in the $\mathrm{IrCl}_{6}{ }^{2-}$ series, the ratio of rate constant of $2-\mathrm{C}_{3} \mathrm{H}_{7} \mathrm{CrL}\left(\mathrm{H}_{2} \mathrm{O}\right)^{2+}$ over that of $1-\mathrm{C}_{3} \mathrm{H}_{7} \mathrm{CrL}\left(\mathrm{H}_{2} \mathrm{O}\right)^{2+}$ is ca. $8 \times 10^{3}$ whereas in the $\mathrm{Br}_{2}{ }^{-}$and $(\mathrm{SCN})_{2}-$ series is only $\mathrm{ca} .6$.

Apparently, an $x_{2}{ }^{--}$oxidant reacts quite differently with $\mathrm{RCrL}\left(\mathrm{H}_{2} \mathrm{O}\right)^{2+}$, as compared to transition metal complexes. For example, $4-\mathrm{CH}_{3} \mathrm{C}_{6} \mathrm{H}_{4} \mathrm{CH}_{2} \mathrm{CrL}\left(\mathrm{H}_{2} \mathrm{O}\right)^{2+}$ reacts with $\operatorname{IrCl}_{6}{ }^{2-}\left(E^{0}=0.89 \mathrm{~V}^{10}\right)$ and $\mathrm{Ru}(\mathrm{bpy})_{3}{ }^{3+}$ $\left(E^{0}=1.26 \mathrm{~V}^{11}\right)$ at specific rates of $4.60 \times 10^{5} \mathrm{M}^{-1} \mathrm{~S}^{-1} 12$ and $1.05 \times 10^{9}$ $M^{-1} s^{-1} 13$ respectively. The observed $5 \times 10^{3}$ times difference in rate constants is quite consistent with what is predicted by Marcus theory based on a pure outer-sphere electron transfer mechanism. But the linearity and the typical slope of 0.5 are no longer obtainable in a plot of lnk vs. $E^{\circ}$ (oxidants) with a series of oxidants including any $x_{2} \cdot-$, even though the charge carried by $\mathrm{X}_{2}{ }^{-}$is between those carried $\mathrm{IrCl}_{6}{ }^{2-}$ and $R u(b p y) 3^{3+}$.

It is noticeable that the small changes of $k$ along the series of alkyl group or along the series of $x_{2} \cdot-$ can not be accounted for by the intrinsic modest response of rate constant to the driving force in the "plateau region" of a lnk vs. $E^{O}$ plot, since bigger responses were observed with other oxidants (e.g., $\left.\operatorname{IrCl}_{6}{ }^{2-}\right) .12$ 
All these facts seem to suggest the formation of a loosely bound adduct $\left\{\mathrm{X}_{2}{ }^{-}, \mathrm{RCrL}\left(\mathrm{H}_{2} \mathrm{O}\right)^{2+}\right\}$ prior to the electron transfer step.

$$
\begin{array}{lll}
\mathrm{X}_{2} \cdot-+\operatorname{RCrL}\left(\mathrm{H}_{2} \mathrm{O}\right)^{2+}====\left\{\mathrm{X}_{2} \cdot-, \operatorname{RCrL}\left(\mathrm{H}_{2} \mathrm{O}\right)^{2+}\right\} & k_{6}, k_{-6} & \text { (III-6) } \\
\left\{\mathrm{X}_{2}{ }^{-}, \operatorname{RCrL}\left(\mathrm{H}_{2} \mathrm{O}\right)^{2+}\right\} \longrightarrow 2 X^{-}+\operatorname{RCrL}\left(\mathrm{H}_{2} \mathrm{O}\right)^{3+} & k_{7} & \text { (III-7) }
\end{array}
$$

If

$$
k=\frac{k_{\text {obs }}}{\left(\operatorname{RCrL}\left(\mathrm{H}_{2} \mathrm{O}\right)^{2+1}\right)}=\frac{k_{6} k_{7}}{k_{-6}+k_{7}}
$$

and $1 f k_{7}$ is proportional to the driving force for the electron transfer step as predicted by Marcus equation, 9 the depressed response of the change in $k$ values to the change of $E^{\circ}$ values of $x_{2}$ - must indicate a very small $\left(k_{6} /\left(k_{-6}+k_{7}\right)\right.$ value. This implies a very unstable adduct with respect to both dissociation and electron transfer.

While we can not exclude the possibility for the adduct to be an ion patring complex, we are inclined to suggest that the adduct reflects an interaction between $\mathrm{x}_{2}{ }^{-}$and the $\alpha$-carbon of the alkyl group bound to chromium. This is because: (1) No indication of ion pairing was observed in the previous study when the charge of the oxidants changed from 2- $\left(\mathrm{IrCl}_{6}{ }^{2-}\right)$ to $3+\left(\mathrm{Fe}^{3+}\right) \cdot 12$ (2) As revealed in Table III-1, the depressed response of the change of $k$ to the change of alkyl group in $\operatorname{RCrL}\left(\mathrm{H}_{2} \mathrm{O}\right)^{2+}$ was observed with singly charged $\mathrm{X}_{2} \cdot-$ series whereas a much larger response was observed with doubly charged $\operatorname{IrCl}_{6}{ }^{2-}$. We believe that the interaction $\mathrm{X}_{2}---\mathrm{RCrL}\left(\mathrm{H}_{2} \mathrm{O}\right)^{2+}$ bears an intrinsic connection with the polarizing ability of halogens. While a direct attack by $x_{2} \cdot-$ at a $\alpha$-carbon bound to a metal is not known, the same attack by $x_{2}$ is well 
documented. ${ }^{7}$ Perhaps the major difference between the atlack by $x_{2}$ and that by $\mathrm{x}_{2}{ }^{-}$- is that the former is a two electron reagent thus the electrophilic substitution products $\left(\mathrm{X}^{-}, \mathrm{RX}, \mathrm{CrL}\left(\mathrm{H}_{2} \mathrm{O}\right)^{3+}\right)$ were formed $^{1}$ and the latter is an one electron reagent ${ }^{6}$ hence the electron transfer products $\left(2 \mathrm{X}^{-}, \mathrm{RCrL}\left(\mathrm{H}_{2} \mathrm{O}\right)^{3+}\right)$ were formed. 


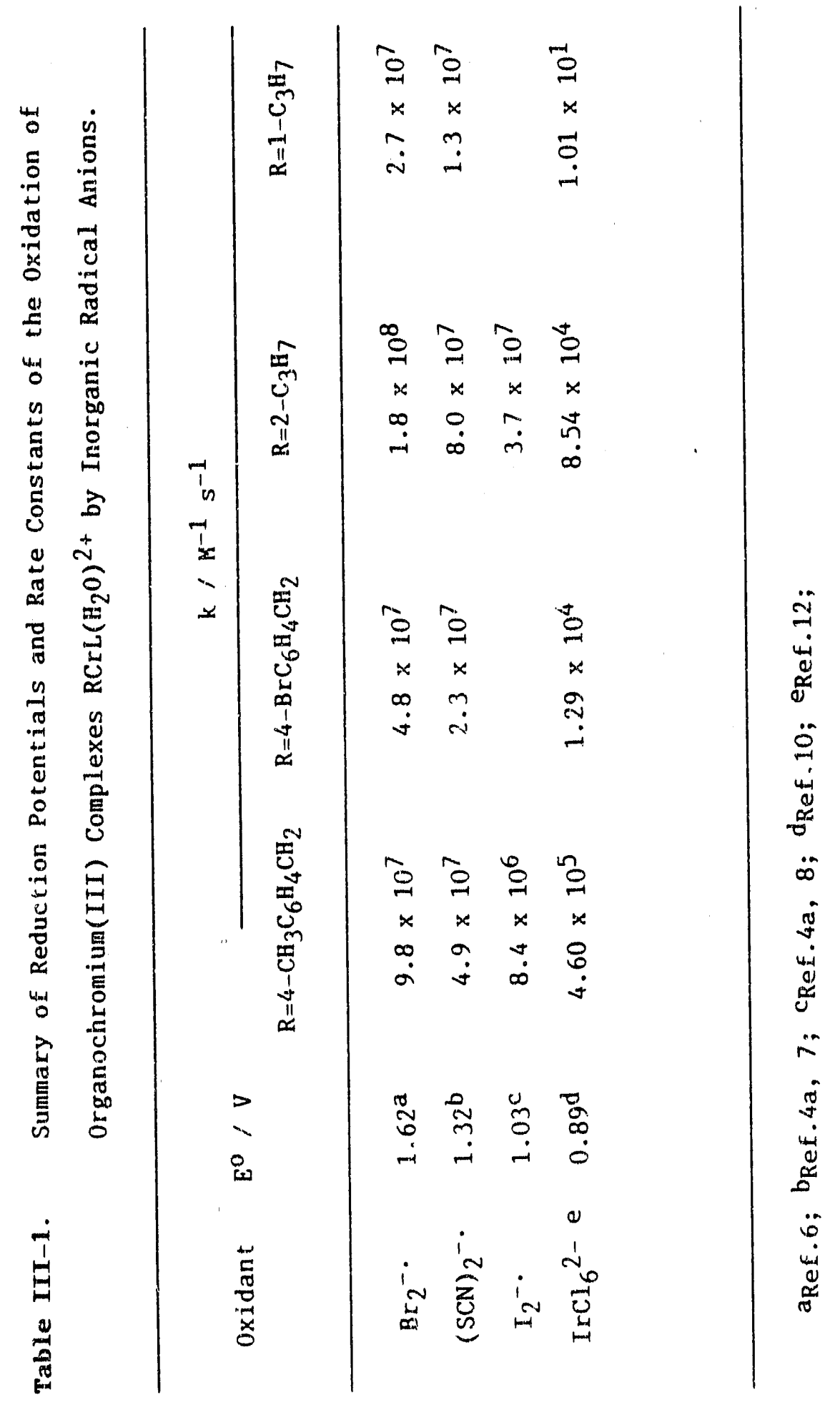




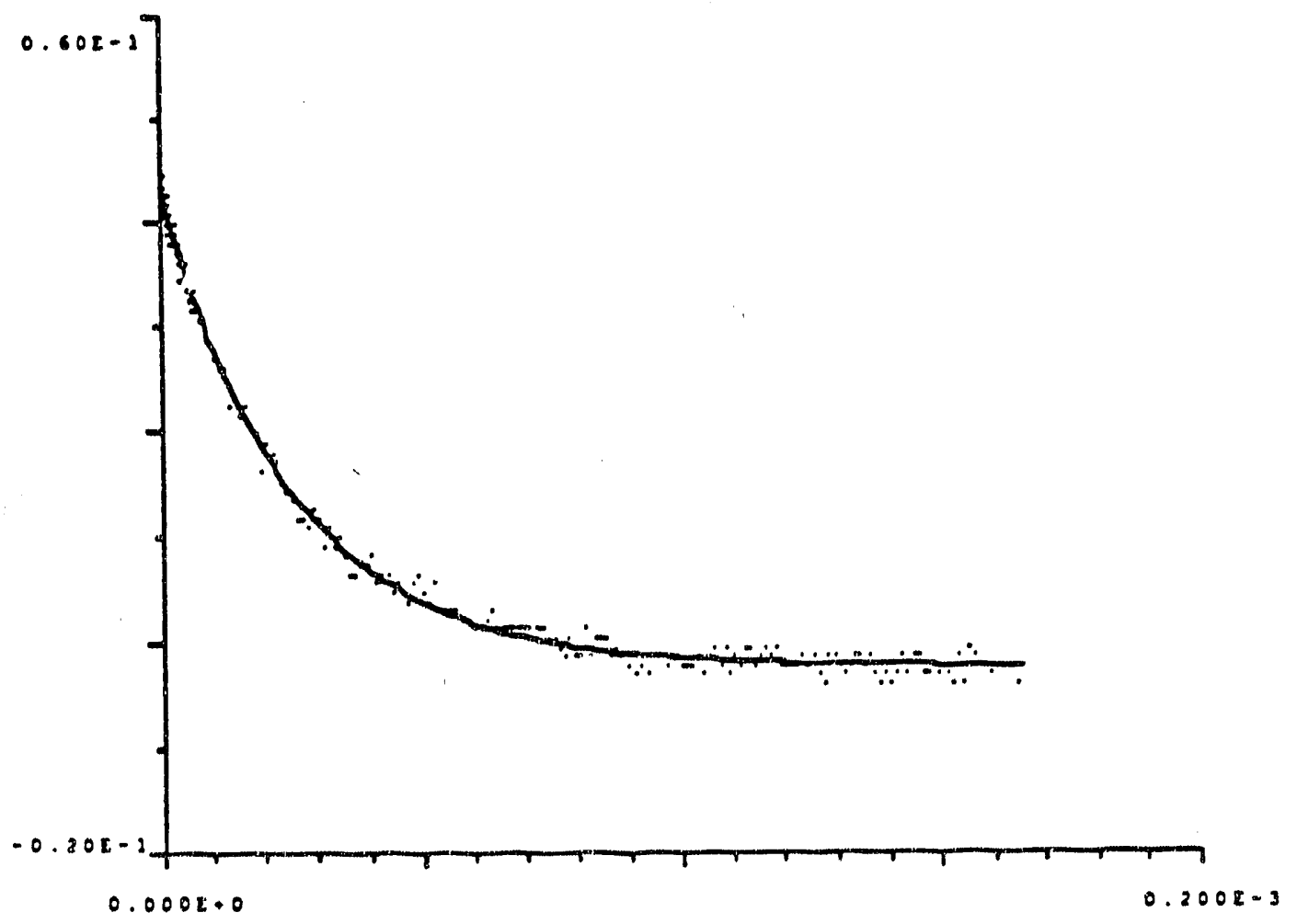

Figure III-1. An observed kinetic trace of the oxidation of $4-\mathrm{CH}_{3} \mathrm{C}_{6} \mathrm{H}_{4} \mathrm{CH}_{2} \mathrm{CrL}\left(\mathrm{H}_{2} \mathrm{O}\right)^{2+}\left(2.5 \times 10^{-4} \mathrm{M}\right)$ by $\mathrm{Br}_{2}-$ generated by pulse radiolysis. $\mathrm{N}_{2} \mathrm{O}$-saturated aqueous solution Monitored at $\lambda=400 . \mathrm{nm}$. Room temperature. The solid curve was calculated from a pseudo-first-order data fitting prograli 


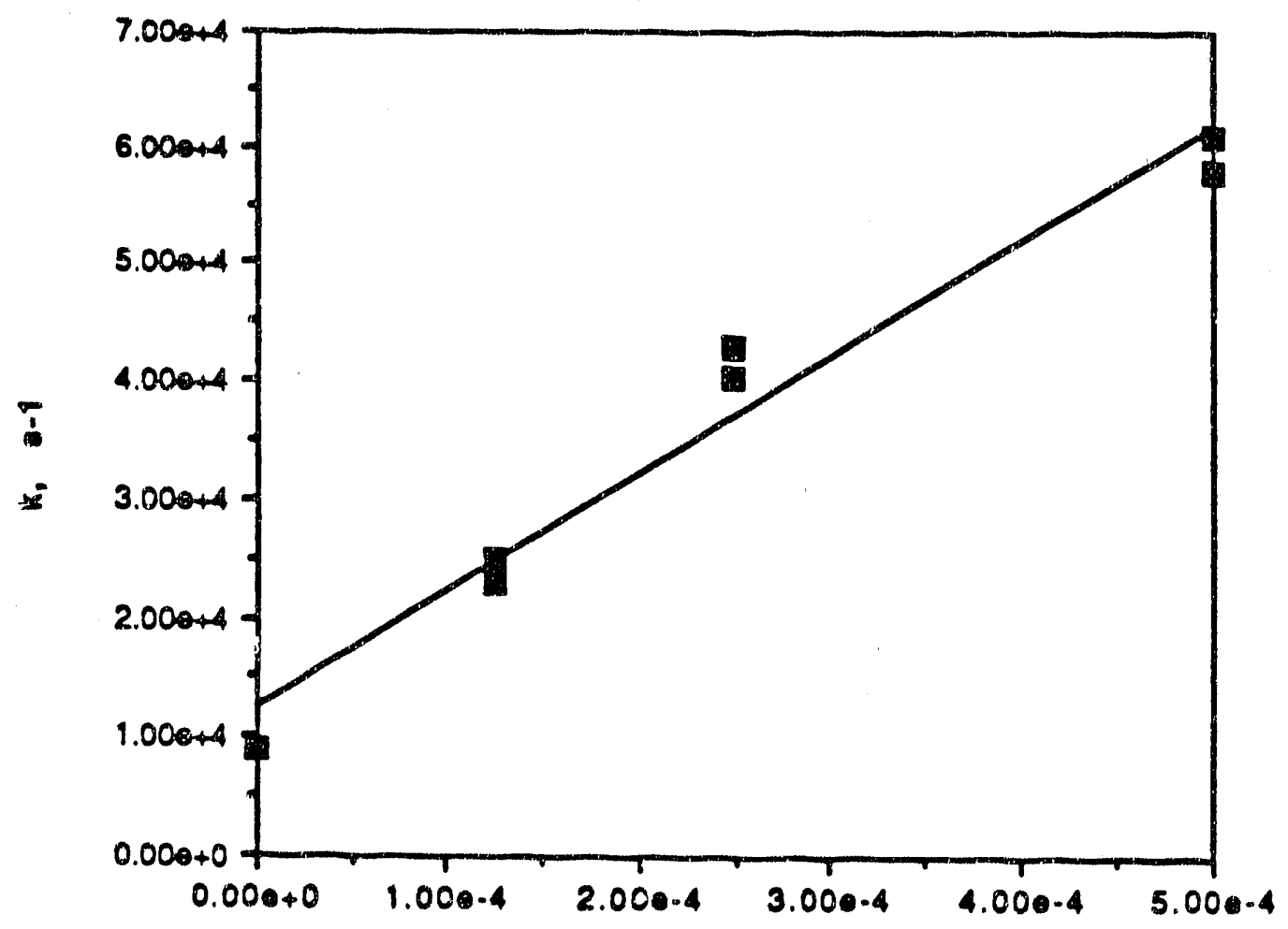

Pigure III-2. A plot showing a linear relationship between the observed pseudo-first-order rate constant $k_{o b s}$ and the concentration of $4-\mathrm{CH}_{3} \mathrm{C}_{6} \mathrm{H}_{4} \mathrm{CH}_{2} \mathrm{CrL}\left(\mathrm{H}_{2} \mathrm{O}\right)^{2+}$ (excess) for the reaction between $4-\mathrm{CH}_{3} \mathrm{C}_{6} \mathrm{H}_{4} \mathrm{CH}_{2} \mathrm{CrL}\left(\mathrm{H}_{2} \mathrm{O}\right)^{2+}$ and $\mathrm{Br}_{2}{ }^{--}$ 


\section{REFERENCES}

(1) Shi, S.; Espenson, J. H.; Bakac, A. J.Am. Chem. Soc, 1990, 112, 1841.

(2) Samuels, G. J.; Espenson, J. H. Inorg. Chem. 1979, 18, 2587.

(3) Shi, S.; Espenson, J. H.; Bakac, A. Inorg. Chem. 1990, 29, 4318.

(4) For a review, see (a) Stanbury, D.M. Adv. Inorg. Chem. 1989, 33, 69. (b) Fornier de Violet Rev. Chem. Intermediates 1981, 4, 121.

(5) (a) Teinin, A.; Hayon, E.; J. Am. Chem. Soc. 1975, 97, 1716 . (b) Fornier de Violet, P.; Bonneau, R.; Joussot-Dubien, J. Chem. Phys. Lett. 1973, 5, 61. (c) Fornier de Violet, P.; Bonneau, R.; Joussot-Dubien, J. J. Chim. Phys. 1973, 70, 1404.

(6) (a) Laurence, G. S.; Thornton, A. T. J. Chem. Soc., Dalton Trans. 1973, 1637. (b) Schwarz, H. A.; Dodson, R. W. J. Phys. Chem. $1984, \underline{8}, 3643$.

(7) (a) Nord, C.; Pederson, B.; Farver, 0. Inorg. Chem. 1978, 17, 2233. (b) Nord, C.; Pederson, B.; Floryan-lovberg, E.; Pagsberg, P. Inorg. Chem. 1982, 21, 2327.

(8) Haim, A.; Taube, H. J.Amer. Chem. Soc. 1963, 85, 495.

(9) Marcus, R.A. J. Chem. Phys. 1965, 43, 679, 2654.

(10) Margerum, D. W.; Chellappa, K. L.; Bossu, F. P.; Burce, G. L. J. Am. Chem. 1975, 97, 6894.

(11) Sutin, N.; Creutz, C. Adv. Chem. Ser. 1978, No. 168, 1.

(12) Shi, S.; Bakac, A.; Espenson, J.H. (to be published), or see Part IV of this thesis.

(13) Steffan, C. Ph.D. thesis, Iowa State University, 1990. 
(14) (a) Espenson, J. H.; Williams, D. A. J. Am. Chem. Soc. 1974, 96, 1008 (b) Chang, J. C.; Espenson, J. H. J. Chem. Soc., Chem. Commun. 1974, 233. (c) Espenson, J. H.; Samuel, G. J. J. organomet. Chem. 1976, 113, 143. 
PART IV. REVERSIBLE ELECTRON TRANSFER REACTIONS OF ORGANOCHROMIUH(III) MACROCYCLIC COHPLEXES 


\section{INTRODUCTION}

Transition metal complexes containing metal-carbon bonds are known to participate in various oxidation mechanisms. 1 Unlike inorganic complexes, where the metal may exist in two or more stable oxidation states (particularly with well-chosen ligand sets), an one electron oxidation of the organometal (RM) yields a species $\left(R M^{+}\right)$which of ten undergoes ready decomposition, usually by homolysis $\left(R M^{+} \rightarrow R^{*}+M^{+}\right)$.

The series of complexes $\left(\mathrm{H}_{2} \mathrm{O}\right)_{5} \mathrm{CrR}^{2+}$ is oxidized by strong oneelectron acceptors such as $\mathrm{Ni}(\text { cyclam })^{3+}, E^{0} 1.0 \mathrm{~V}_{i}^{2} \mathrm{Ru}(\mathrm{bpy}) 3^{3+}, \mathrm{E}^{\mathrm{O}} 1.27$ $\mathrm{V}$; and $\mathrm{NO}^{+}$, $\mathrm{E}^{\mathrm{O}} 1.51 \mathrm{~V} .{ }^{2-4}$ Each of these reactions yields $\left(\mathrm{H}_{2} \mathrm{O}\right){ }_{5} \mathrm{CrR}^{3+}$ as a transient. Although not (yet) detected directly, the presence of this transient is indicated by the formation of $\mathrm{Cr}\left(\mathrm{H}_{2} \mathrm{O}\right)_{6}{ }^{3+}$, by products derived from $R^{\cdot}$, and by stoichiometric factors that become incorporated into some rate constants. Interestingly, the much milder 5,6 oxidant $\mathrm{Br}_{2}$ reacts with $\left(\mathrm{H}_{2} \mathrm{O}\right)_{5} \mathrm{Cr}^{2+}$ by a straightforward electrophilic mechanism $\left(\mathrm{S}_{\mathrm{E}} 2\right), 7$ and not by an oxidative process.

The mechanism of chromium-carbon bond cleavage by halogens changes, however, when this organometal is incorporated into a macrocyclic ligand. Even with a mild acceptor like $\mathrm{I}_{2}, 8$ the complexes $\operatorname{SSRS-RCrL}\left(\mathrm{H}_{2} \mathrm{O}\right)^{2+}(\mathrm{R}=$ $\mathrm{ArCH}_{2}, 2^{\circ}-a$ r.y $; \mathrm{L}=1,4,8,12$-terraazacyrinpentadecane) react by a radical chain mechanism in which the initiating step is electron transfer (eq IV-1). 9 presumably the macrocycle, a much more electron-donating ligand, lowers the potential such that its organochromium complexes are more readily oxidized. 


$$
\mathrm{RCrL}\left(\mathrm{H}_{2} \mathrm{O}\right)^{2+}+\mathrm{I}_{2} \longrightarrow \mathrm{RCrL}\left(\mathrm{H}_{2} \mathrm{O}^{3++}+\mathrm{I}_{2}{ }^{\cdot-}\right.
$$

It thus became of interest to examine the reactions with other species capable of oxidizing the $\operatorname{RCrL}\left(\mathrm{H}_{2} \mathrm{O}\right)^{2+}$ complexes. One problem in gaining a fundamental understanding of such reactions is the lack of information about the $\mathrm{RM}^{+} / \mathrm{RM}$ reduction potential and self-exchange rate (SER). Kinetic studies can provide an approach to both issues by relating a given cross reaction to the reduction potential by means of the Marcus-Hush theory. The approach we suggest is to use two oxidants for a given $\operatorname{RCrL}\left(\mathrm{H}_{2} \mathrm{O}\right)^{2+}$ complex, from which the $E^{\circ}$ and SER of the $\mathrm{RCrL}^{3+/ 2+}$ couple can be estimated.

We have first chosen to examine the oxidation of one organometal, $4-\mathrm{BrC}_{6} \mathrm{H}_{4} \mathrm{CH}_{2} \mathrm{CrL}\left(\mathrm{H}_{2} \mathrm{O}\right)^{2+}$, by a series of electron acceptors: $\mathrm{ABTS}^{\circ}-\left(\mathrm{A}^{-}\right)$, $\mathrm{IrCl}_{6}{ }^{2-}$, and $\mathrm{Fe}\left(\mathrm{H}_{2} \mathrm{O}\right)_{6}{ }^{3+}$. This enables the electron-transfer mechanism to be considered in the absence of $E^{O}$ and the $3 E R$ for $\operatorname{RCrL}\left(\mathrm{H}_{2} \mathrm{O}\right)^{2+}$. Then two oxidants were chosen such that one is weak $\left(\operatorname{ABCS}^{\circ}-12-, E^{\circ}=\right.$ $0.43 \mathrm{~V})$, the other strong $\left(E^{\mathrm{O}} \mathrm{IrCl}_{6}=0.89 \mathrm{~V}\right)$. With the weak oxidant, the retarding effect of $\mathrm{ABTS}^{2-}$ can be tested experimentally, which can in turn provide an additional rate constant ratio from which a lower limit can be set for the kinetic lifetime of the purported product, $\operatorname{RCrL}\left(\mathrm{H}_{2} \mathrm{O}\right)^{3+}$. An upper limit of the lifetime of $\mathrm{RCrL}\left(\mathrm{H}_{2} \mathrm{O}\right)^{3+}$ can then be set by its reaction rate with the strong oxidant. A combination of these limits allows an estimate of the $E^{O}$ value and SER constant of the $\operatorname{RCrL}\left(\mathrm{H}_{2} \mathrm{O}\right)^{3+/ 2+}$ couple. 
As far as the oxidation processes themselves are concerned, we ask the following questions. How are the $\mathrm{RCrL}\left(\mathrm{H}_{2} \mathrm{O}\right)^{2+}$ species oxidized? What are the decomposition products of $\operatorname{RCrL}\left(\mathrm{H}_{2} \mathrm{O}\right)^{3+}$ ? What is the rate of 1 ts decomposition, and how does it compare to that of its $2+$ parent? What role do the $R$ groups play? What is the structure of transition state of the electron-transfer process? We have focused with ABTS'- primarily on $4-\mathrm{BrC}_{6} \mathrm{H}_{4} \mathrm{CH}_{2} \mathrm{CrL}\left(\mathrm{H}_{2} \mathrm{O}\right)^{2+}$, whose reaction with lodine was the one most carefully studied. 9 with $\operatorname{IrCl}_{6}{ }^{2-}$ as oxidant, an entire range of alkyl and aralkyl groups wàs explored. 


\section{EXPERIMENTAL SECTION}

Materials. The organochromium macrocyclic complexes $\mathrm{RCri}\left(\mathrm{H}_{2} \mathrm{O}\right)^{2+}$ with $\mathrm{R}=\mathrm{C}_{2} \mathrm{H}_{5}, 1-\mathrm{C}_{3} \mathrm{H}_{7}, 2-\mathrm{C}_{4} \mathrm{H}_{9}, 4-\mathrm{CH}_{3} \mathrm{C}_{6} \mathrm{H}_{4} \mathrm{CH}_{2}, \mathrm{C}_{6} \mathrm{H}_{5} \mathrm{CH}_{2}$, and $4-\mathrm{BrC}_{6} \mathrm{H}_{4} \mathrm{CH}_{2}$ were obtained from the reaction of $\left(\mathrm{H}_{2} \mathrm{O}\right)_{2} \mathrm{CrL}^{2+}$ and $\mathrm{RX}$ and purified by ion exchange on Sephadex $c-25.9,10$ The following molar absorptivities were determined, which were then used to calculate the concentrations of the complexes for the kinetic studies. For $\mathrm{R}=1-\mathrm{C}_{3} \mathrm{H}_{7}$, $\lambda_{\max } / \mathrm{nm}\left(\varepsilon / \mathrm{L} \mathrm{mol}^{-1} \mathrm{~cm}^{-1}\right)=265\left(3.44 \times 10^{3}\right)$ and $383\left(4.65 \times 10^{2}\right) ; 2-\mathrm{C}_{3} \mathrm{H}_{7}$, $287\left(3.28 \times 10^{3}\right)$ and $396\left(5.50 \times 10^{2}\right) ; 2-\mathrm{C}_{4} \mathrm{H}_{9}, 292\left(3.31 \times 10^{3}\right)$ and $390(5.60$ $\left.\times 10^{2}\right) ; 4-\mathrm{CH}_{3} \mathrm{C}_{6} \mathrm{H}_{4} \mathrm{CH}_{2}, 243\left(6.72 \times 10^{3}\right), 281\left(7.65 \times 10^{3}\right)$, and $302(6.78 \times$ $\left.10^{3}\right) ; \mathrm{C}_{6} \mathrm{H}_{5} \mathrm{CH}_{2}, 273\left(7.92 \times 10^{3}\right), 297\left(7.47 \times 10^{3}\right)$, and $353\left(2.17 \times 10^{3}\right)$; $4-8 \mathrm{rC}_{6} \mathrm{H}_{4} \mathrm{CH}_{2}, 247\left(1.07 \times 10^{4}\right), 281\left(9.82 \times 10^{3}\right), 303\left(8.83 \times 10^{3}\right)$, and $\left.36.2 .40 \times 10^{3}\right) \cdot 9-11$

The compound $\left(\mathrm{NH}_{4}\right)_{2} \mathrm{ABTS}\left(\alpha, \alpha^{\prime}\right.$-azino-bis(3-ethylbenzthiazoline6-sulfonic acid)diammonium salt, see structural formula) was purchased (Aldrich); it was converted to the radical ion $\mathrm{ABTS}^{\circ}-$ by oxidation with an equivalent amount of ceric ammonium sulfate. The radical ABTS'-

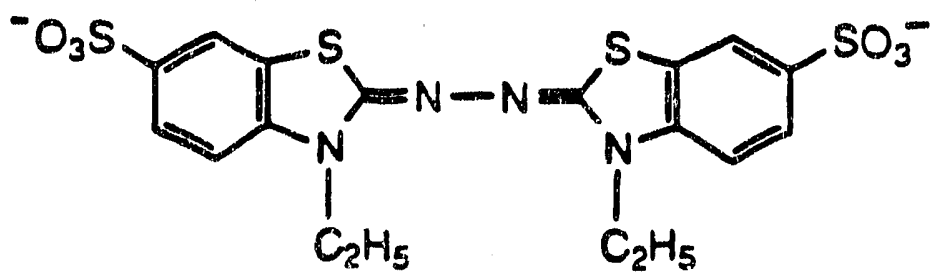

\section{ABTS $^{2-}$}

persists in solutions for several weeks; it is characterized by a number of UV-visible absorption bands of which the peak at $650 \mathrm{~nm}\left(\varepsilon 1.01 \times 10^{4}\right.$ $\mathrm{L} \mathrm{mol}^{-1} \mathrm{~cm}^{-1}$ ) was used to follow its reactions, other reagents were obtained from standard sources and used as received. 
Techniques, Kinetics. Kinetic measurements were conducted at $25{ }^{\circ} \mathrm{C}$ with $\left[\mathrm{H}^{+}\right]=1.0 \times 10^{-2} \mathrm{M}$ (perchloric acid) and iontc strength $0.20 \mathrm{M}$ (maintained with sodium perchlorate). Alr-free conditions were maintained in all experiments by a blanket of argon. Depending on the rate constant for a given reaction, kinetic data were collected with a Durrum-Dionex stopped flow spectrophotometer or a conventional spectrophotometer, a modified Cary 14. Both instruments are controlled by the on Line Instrument Systems data acquisition and analysis software. Kinetic data were Eit to the equation $D_{t}=D_{\infty}+\left(D_{0}-D_{\infty}\right) \exp \left(-k_{\psi} t\right)$ by a nonlinear least-squares method. 
RESULTS AND DISCUSSION

Reactions of $4-\mathrm{BrC}_{6} \mathrm{~B}_{4} \mathrm{CH}_{2} \mathrm{CrL}\left(\mathrm{B}_{2} \mathrm{O}\right)^{2+}$ with $\mathrm{ABTS}^{\circ}-$. The $\mathrm{ABTS}{ }^{\circ}-\operatorname{radical}$ functions as an oxidizing agent with $E^{0}=0.43 \mathrm{~V}_{*} 12$ we suggest that, following the electron transfer step, the species $\operatorname{RCrL}\left(\mathrm{H}_{2} \mathrm{O}\right)^{3+}$ undergoes homolysis, with the resulting radical forming an adduct with ABTS $^{\circ}-$ in a known reaction. 13 These reactions are shown as follows:

$$
\begin{gathered}
\operatorname{RCrL}\left(\mathrm{H}_{2} \mathrm{O}\right)^{2+}+\mathrm{ABTS}^{\circ} \longrightarrow \operatorname{RCrL}\left(\mathrm{H}_{2} \mathrm{O}\right)^{3+}+\mathrm{ABTS}^{2-}\left(\mathrm{k}_{2}, \mathrm{k}_{2}\right) \\
\operatorname{RCrL}\left(\mathrm{H}_{2} \mathrm{O}\right)^{3+}+\mathrm{H}_{2} \mathrm{O} \longrightarrow \mathrm{R}^{\cdot}+\left(\mathrm{H}_{2} \mathrm{O}_{2}{ }_{2} \mathrm{Crl}^{3+}\left(\mathrm{k}_{3}\right)\right. \\
\mathrm{R}^{\cdot}+\mathrm{ABTS}^{\circ} \longrightarrow{\mathrm{R}-\mathrm{ABTS}^{-}}_{\left(\mathrm{k}_{4}\right)^{13}}
\end{gathered}
$$

According to this scheme, the reactions should show a stolchiometry of $2 \mathrm{ABTS}^{-}-: 1 \mathrm{RCrL}\left(\mathrm{H}_{2} \mathrm{O}\right)^{2+}$. This ratio is indeed found by spectrophotometric titration as shown in Figure IV-1. The rate equation derived on the basis of eq IV-2 to IV-4, with the steady-state approximation for $\left[\mathrm{RCrL}\left(\mathrm{H}_{2} \mathrm{O}\right)^{3+}\right]$, is

$$
\frac{-d\left[\operatorname{RCrL}\left(\mathrm{H}_{2} \mathrm{O}\right)^{2+}\right]}{d t}=\frac{\mathrm{k}_{2} \mathrm{k}_{3}\left[\operatorname{ABTS}^{-}\right]\left[\operatorname{RCrL}\left(\mathrm{H}_{2} \mathrm{O}\right)^{2+}\right]}{k_{3}+k_{-2}\left[\operatorname{ABTS}^{2 \cdots}\right]}=k_{\psi}\left[\operatorname{RCrL}\left(\mathrm{H}_{2} \mathrm{O}\right)^{2+}\right]
$$


With ABTS $^{-}-\left(1.2-12.0 \times 10^{-5} \mathrm{M}\right.$ average conc. $)$ in excess over $4-\mathrm{BrC}_{6} \mathrm{H}_{4} \mathrm{CrL}\left(\mathrm{H}_{2} \mathrm{O}\right)^{2+}\left(2.1-5.9 \times 10^{-6} \mathrm{M}\right)$, and with no added $\mathrm{ABTS}^{2-}$, the expression reduces to $k_{\psi}=k_{2}$ [ABTS $\left.^{\circ}\right]$. This is illustrated in Figure IV-2. The average value of $k_{2}$ is $(1.51 \pm 0.11) \times 10^{2} \mathrm{Lmol}^{-1} \mathrm{~s}^{-1}$ in six determinations. A series of seven experiments was then done with added $\mathrm{ABTS}^{2}$ - (range of average concentrations $7.0 \times 10^{-6}-3.39 \times 10^{-4} \mathrm{M}$ ). Values of $k_{\psi}$ become smaller with increasing [ABTS ${ }^{2-}$ ], as expected from eq IV-5. A nonlinear least-squares $f 1 t$ to eq IV-5 affords an independent estimate of $k_{2}=(1.51 \pm 0.10) \times 10^{2} \mathrm{~L} \mathrm{~mol}^{-1} \mathrm{~s}^{-1}$, and the ratio $\mathrm{k}_{-2} / \mathrm{k}_{3}=$ $(6.7 \pm 0.7) \times 10^{3} \mathrm{~L} \mathrm{~mol}^{-1}$. The effect can be displayed graphically by a rearrangement to eq IV-6, which is useful since all these experdments had [ABTS $\left.^{-}\right]_{\mathrm{aV}}=9.32 \times 10^{-5} \mathrm{M}$. The data are shown according to eq IV-6 in Figure IV-3.

$$
k_{\psi}=k_{2}\left[\text { ABTS }^{\cdot-}\right]_{a v}-\left(k_{-2} / k_{3}\right) k_{, 1,}\left[\operatorname{ABTS}^{2-}\right]_{a v}
$$

oxidations of $4-\mathrm{BrC}_{6} \mathrm{H}_{4} \mathrm{CH}_{2} \mathrm{CrL}\left(\mathrm{B}_{2} \mathrm{O}\right)^{2+}$ by $\mathrm{IrCl}_{6}{ }^{2-}$ and $\mathrm{Pe}\left(\mathrm{H}_{2} \mathrm{O}\right)_{6}{ }^{3+}$. The reaction with $\mathrm{IrCl}_{6}{ }^{2-}$ also proceeds with a $1: 2$ stoichiometry (Figure IV-1). The scheme is analogous to eq IV-2 to IV-4, except that the fate of the radical is oxidation to a mixture of alcohol and halide: 14

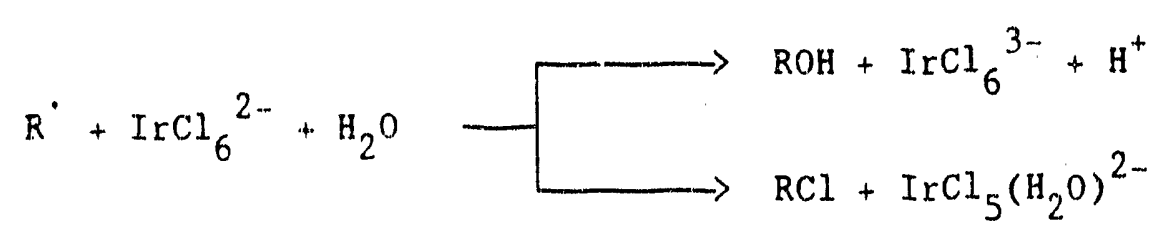


Kinetics experiments were done both with $\left[\mathrm{RCrL}\left(\mathrm{H}_{2} \mathrm{O}\right)^{2+}\right]>10\left[\mathrm{IrCl}_{6}{ }^{2-}\right]_{0}$ and with $\left[\mathrm{IrCl}_{6}{ }^{2-}\right]>10\left[\mathrm{RCoL}\left(\mathrm{H}_{2} \mathrm{O}\right)\right]_{0}$. In all, the concentration variations were $\left[\operatorname{RCrL}\left(\mathrm{H}_{2} \mathrm{O}\right)^{2+}\right]_{0}=1.55 \times 10^{-5}-2.44 \times 10^{-4} \mathrm{M}$ and $\left[\mathrm{IrCl}_{6}{ }^{2-}\right]_{0}=5 \times 10^{-6}-4.5 \times 10^{-3} \mathrm{M}$ in eleven experiments. The reaction follows mixed second-order kinetics with $k=(1.29 \pm 0.18) \times 10^{4} \mathrm{~L} \mathrm{~mol}^{-1}$ $s^{-1}$, where $k$ is defined by the rate law, $-d\left[\operatorname{RCrL}\left(\mathrm{H}_{2} \mathrm{O}\right)^{2+}\right] / d t=$ $-\mathrm{d}\left[\mathrm{IrCl}_{6} 2-\right] / 2 \mathrm{dt}=k\left[\mathrm{RCrL}\left(\mathrm{H}_{2} \mathrm{O}\right)^{2+}\right]\left[\mathrm{IrCl}_{6}{ }^{2-}\right]$.

The reaction with the mild oxidant $\mathrm{Fe}^{3+}\left(E^{\circ} \mathrm{Fe}=0.745 \mathrm{~V}\right)^{15}$ has a $1: 1$ stoichiometry, and produces $\mathrm{Fe}^{2+}$ according to a test of the products with 1,10-phenanthroline. Kinetic data were obtained in 7 experiments with concentrations of $(1.6-8.0) \times 10^{-5} \mathrm{M} \mathrm{Fe}^{3+}$ and $(1.0-6.8) \times 10^{-4} \mathrm{M}$ $\mathrm{RCrL}\left(\mathrm{H}_{2} \mathrm{O}\right)^{2+}$. The second-order rate constant is $3.09 \pm 0.28 \mathrm{~L} \mathrm{~mol}^{-1} \mathrm{~s}^{-1}$. The reaction stoichiometry deserves a comment, in that in the sequence eq IV -2 to IV-4 (modified to include $\mathrm{Fe}^{3+}$ in place of $\mathrm{ABTS}^{-}{ }^{-}$), one expects 16 the final step to be oxidation of the benzyl radical by $\mathrm{Fe}^{3+}\left(\mathrm{ArCH}_{2}{ }^{\circ}+\right.$ $\left.\mathrm{Fe}^{3+}+\mathrm{H}_{2} \mathrm{O} \rightarrow \mathrm{ArCH}_{2} \mathrm{OH}+\mathrm{Fe}^{2+}+\mathrm{H}^{+}\right)$. The stoichiometry indicates this does not occur. We suggest that the oxidation at these very low $\left[\mathrm{Fe}^{3+}\right]$ is too slow to compete with radical dimerization.

Analysis of Oxidation Rates on the Basis of the Marcus Equation. Given that each oxidizjng agent has a knoun reduction potential. $\left(E^{\circ}{ }_{\text {ox }}\right) 12,15,17$ and some have known self-exchange rate constant (k11) 17-19, it is possible to consider the data further. First, the self-exchange rate of $A B T S^{2-1 \cdot-}\left(k_{A A}\right)$ was calculated here from the crossreaction rate constants for the reactions of $\mathrm{RCrL}\left(\mathrm{H}_{2} \mathrm{O}^{2+}\right.$ with $\mathrm{ABTS}^{\circ}-$ 
$\left(k_{A C r}\right)$ and $\operatorname{IrCl}_{6}{ }^{2-}\left(k_{I r C r}\right)$ and their known reduction potentials accol Ing to

$$
k_{A A}=\left\{k_{\operatorname{IrIr}} \exp \left[(F / R T)\left(E^{0} \operatorname{Ir}_{A}-E_{A}^{0}\right)\right]\right\}\left(k_{A C r} / k_{I r C r}\right)^{2}
$$

This yields a value $k_{A A}=2.2 \times 10^{9} \mathrm{Lmol}^{-1} \mathrm{~s}^{-1}$, a quantity not previously reported. That this is a diffusion-controlled value, or nearly so, is consistent with there being very little molecular reorganization accompanying the redox change. With $k_{A A}$ known we can then consider all of the cross reactions according to the simplified Marcus cross relation, $k_{12}=\left(k_{11} k_{22} k_{12}\right)^{1 / 2} ;$ rearrangement yields

$$
2 \operatorname{lnk} k_{12}=\operatorname{lnk} k_{11}+\operatorname{lnk} k_{22}+(F / R T)\left(E_{o x}^{0}-E_{R C r}^{0}\right)
$$

This predicts that a plot of $l^{n} k_{12}$ versus $\left[l_{n k} 11+(F / R T) E^{\circ}{ }_{0 x}\right]$ will be a straight line with a slope of 0.5 . In this series where a given $4-\mathrm{BrC}_{6} \mathrm{H}_{4} \mathrm{CH}_{2} \mathrm{CrL}\left(\mathrm{H}_{2} \mathrm{O}\right)^{2+}$ complex was used, even though neither $k_{22}$ nor $\mathrm{E}^{\mathrm{O}} \mathrm{RCr}$ is known, it is still possible to consider the mechanism of the oxidation. The experimental data are summarized in Tahle IV-1 and plotted according to eq TV-10 in Figure IV-4. The slope of 0.49 indicates that this family of reactions proceeds by an outer-sphere electron transfer mechanism. The intercept is -27.1 , which will be considered later. 
The Reduction Potential, Lifetime and Self-Exchange Rate of $\operatorname{RCrL}\left(\mathrm{H}_{2} \mathrm{O}\right)^{3+}$. The reaction with $\operatorname{IrCl}_{6}{ }^{2-}$ was conducted with either reagent in excess. A single exponential kinetic trace was obtained throughout. The absence of a second stage, even under the concentration conditions where $k_{\psi}$ was the highest observed value $\left(57 \mathrm{~s}^{-1}\right)$, allows us to set a rough lower limit $k_{3}>60 \mathrm{~s}^{-1}$. The same limit of $k_{3}$ should hold for the oxidation by $\mathrm{ABTS}^{\circ}-$ as well. Since the ratio $k_{-2} / k_{3}$ is known $(6.7$ $\times 10^{3} \mathrm{~L} \mathrm{~mol}^{-1}$ ) for ABTS $^{-}$, we can set broad limits on $k_{-2}: 4 \times 10^{5}-1$ $\times 10^{10} \mathrm{~L} \mathrm{~mol}^{-1} \mathrm{~s}^{-1}$, which combined with $k_{2}=1.5 \times 10^{2} \mathrm{~L} \mathrm{~mol}^{-1} \mathrm{~s}^{-1}$ and $E^{\circ}{ }_{A}=0.43 \mathrm{~V}$ affords a limit for the reduction potential of $4-\mathrm{BrC}_{6} \mathrm{H}_{4} \mathrm{CH}_{2} \mathrm{CrL}\left(\mathrm{H}_{2} \mathrm{O}\right)^{3+/ 2+}: 0.89>\mathrm{E}^{\mathrm{O}} \mathrm{RCr}>0.63 \mathrm{~V}$. We therefore adopt the value $\mathrm{E}^{\circ}{ }_{\mathrm{RCr}}=0.76 \pm 0.13 \mathrm{~V}$.

With this potential, a cross-reaction rate constant $k_{12}=1.15 \times 10^{4}$ $\mathrm{L} \operatorname{mol}^{-1} \mathrm{~s}^{-1}$ for $\operatorname{RCrL}\left(\mathrm{H}_{2} \mathrm{O}\right)^{2+}$ with $\operatorname{IrCl}_{6}{ }^{2-}, \mathrm{k}_{\mathrm{IrIr}}=2.0 \times 10^{5} \mathrm{~L} \mathrm{~mol}^{-1} \mathrm{~s}^{-1}$, and $E^{0}{ }_{\text {Ir }}=0.89 \mathrm{~V}, 17$ we calculate a self-exchange rate constant of ca. 4 $L \operatorname{mol}^{-1} \mathrm{~s}^{-1}$ for $\mathrm{RCrL}\left(\mathrm{H}_{2} \mathrm{O}\right)^{3+/ 2+}$. With the range of $\mathrm{E}^{\mathrm{O}} \mathrm{RCr}$ values, the self-exchange rate constant may be better expressed as a range: $5 \times 10^{-2}$ $<\mathrm{k}<7 \times 10^{2} \mathrm{Lmol}^{-1} \mathrm{~s}^{-1}$.

The intercept in Figure IV-4, (-27.1) represents an experimentally measured value of $1 \mathrm{nk}_{22}-(\mathrm{F} / \mathrm{RT}) \mathrm{E}^{\mathrm{O}}{ }_{\mathrm{RCr}}$ based on eq IV-10. The value of

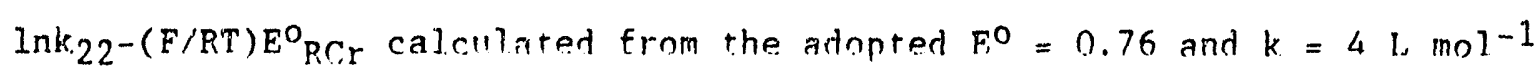
$\mathrm{s}^{-1}$ is $\ln (4)-(\mathrm{F} / \mathrm{RT})(0.76)=-28.2$. The two values are in reasonable agreenent with each other. 
Oxidation of Various $\operatorname{RCrL}\left(\mathrm{B}_{2} \mathrm{O}\right)^{2+}$ Complexes by $\mathrm{IrCl}_{6}{ }^{2-}$. These reactions also proceed with a stoichiometry of $1 \mathrm{RCrL}\left(\mathrm{H}_{2} \mathrm{O}\right)^{2+}: 2 \mathrm{IrCl}_{6}{ }^{2-}$ and a mixed second-order rate law. Kinetic data are summarized in Table IV-2. The rate constants span a factor of $2 \times 10^{6}$, from $\mathrm{Me}(\mathrm{k}=0.22 \mathrm{~L}$ $\left.\mathrm{mol}^{-1} \mathrm{~s}^{-1}\right)$ to $\mathrm{p}$-xylyl $\left(4.6 \times 10^{5} \mathrm{~L} \mathrm{~mol}^{-1} \mathrm{~s}^{-1}\right)$. Among the aralkyl complexes, there is a clear trend in reactivity in which electrondonating substituents on the benzene ring facilitate the reaction. The data are fit by a Hammett correlation, $\log k_{x}=\log k_{H}+\sigma_{p} p$. The reaction constant so derived is $\rho=-4.3$. This substantial and negative value implies a transition state at which the (formal) benzylic carbanton has become substantially more radical-like in character. That is, electron transfer to $\operatorname{IrCl}_{6}{ }^{2-}$ is substantially advanced at the transition state. We conclude from the magnitude of $p$ that the site of oxidation is indeed the benzylic carbon and not the more distant chromium center.

This conclusion is consistent with the kinetic trends within the series of alkyl complexes, where the rate progression is $\mathrm{CH}_{3} \ll \mathrm{C}_{2} \mathrm{H}_{5} \tilde{=}$ $1-\mathrm{C}_{3} \mathrm{H}_{7}=1-\mathrm{C}_{4} \mathrm{H}_{9}\left\langle 2-\mathrm{C}_{3} \mathrm{H}_{7} \sim 2-\mathrm{C}_{4} \mathrm{H}_{9}\right.$. That is, the reaction is clearly not hindered by steric bulk of the group $R$. This again signals a mechanism in which electron transfer is rate controlling.

An interesting comparison can be made about the rate constant $k_{3}\left(k_{3}\right.$ $>k_{1}\left(\mathrm{IrCl}_{6}{ }^{2-}\right]_{\max }-\left(57 \mathrm{~s}^{-1}\right.$ for $\mathrm{R}=4-\mathrm{BrC}_{6} \mathrm{H}_{1} \mathrm{CH}_{7}$ to $92 \mathrm{~s}^{-1}$ for $\left.\mathrm{R}=2\left(\mathrm{r}_{3} \mathrm{H}_{7}\right)\right)$ of $\operatorname{RCrL}\left(\mathrm{H}_{2} \mathrm{O}\right)^{3+}$ and the homolysis rate constant $k_{3}^{\prime}$ of $\operatorname{RCrL}\left(\mathrm{H}_{2} \mathrm{O}\right)^{2+}$ (kom $\left.10^{-4} \mathrm{~s}^{-1}\right), 11$ where $R=$ aralkyl and $2^{0}$-alkyl. We believe that it is the different charge distribution in the transition state that causes $k_{3} \gg$ $k_{\text {hom }}$, 
According to the rules usually used for metal alkyls, the transient species $\mathrm{RCr}\left([15] \operatorname{aneN}_{4}\right)\left(\mathrm{H}_{2} \mathrm{O}\right)^{3+}$ are "assigned" as containing chromium in oxidation state +4 . We note the $\mathrm{PhCH}_{2} \mathrm{Co}(\mathrm{dmgH})_{2}{ }^{+}$inalogues certainly are complexes of cobalt(IV), because their kinetic lifetimes are sufficiently long to allow an assignment from EPR data. 20-23 The reactivities of the two series are very different. The one undergoes untmolecular homolysis, eq IV-11, while the other is subject to nucleophilic attack, e.g., eq IV12. 23-26 It is therefore not at all unreasonable to suggest that the entities $\operatorname{RCr}\left([15]_{a n e N_{4}}\right)\left(\mathrm{H}_{2} \mathrm{O}\right)^{3+}$ are more reasonably formulated as $\mathrm{Cr}$ (III) complexes of $R^{\cdot}$, rather than $\operatorname{Cr}\left(\right.$ IV) complexes of $R^{-}$. Further experiments on the oxidized organochromium species are in progress.

$$
\begin{gathered}
\mathrm{RCrL}\left(\mathrm{H}_{2} \mathrm{O}\right)^{3+}+\mathrm{H}_{2} \mathrm{O} \longrightarrow \mathrm{R}^{*}+\left(\mathrm{H}_{2} \mathrm{O}_{2} \mathrm{CrL}^{3+}\right. \\
\mathrm{PhCH}_{2} \mathrm{Co}(\mathrm{dmgH})_{2} \mathrm{OH}_{2}^{+}+\mathrm{Cl}^{-}+\mathrm{H}_{2} \mathrm{O} \longrightarrow \mathrm{PhCH}_{2} \mathrm{Cl}+\left(\mathrm{H}_{2} \mathrm{O}_{2} \mathrm{Co}(\mathrm{dmgH})_{2}\right.
\end{gathered}
$$


Table IV-1. Reduction Potentials, Self-Exchange Rate Constants and Cross-Reaction Rate Constants ${ }^{a}$ Pertaining to the Oxidation of $4-\mathrm{BrC}_{6} \mathrm{H}_{4} \mathrm{CH}_{2} \mathrm{Cr}\left([15]\right.$ aneN $\left.\mathrm{N}_{4}\right)\left(\mathrm{H}_{2} \mathrm{O}\right)^{2+}$

\begin{tabular}{llll} 
oxidant & $\mathrm{k}_{12} / \mathrm{L} \mathrm{mol}^{-1} \mathrm{~s}^{-1}$ & $\mathrm{k}_{11} / \mathrm{L} \mathrm{mol}^{-1} \mathrm{~s}^{-1}$ & $\mathrm{E}_{\mathrm{ox}}^{\mathrm{o}} / \mathrm{V}$ \\
\hline $\mathrm{IrCl}_{6}{ }^{2-}$ & $(1.29 \pm 0.18) \times 10^{4}$ & $2.0 \times 10^{5 \mathrm{~b}}$ & $0.892^{\mathrm{c}}$ \\
$\mathrm{ABTS}^{-}-$ & $(1.55 \pm 0.11) \times 10^{2}$ & $2.2 \times 10^{9 \mathrm{~d}}$ & $0.43 \mathrm{e}$ \\
$\mathrm{Fe}\left(\mathrm{H}_{2}{ }^{0}\right)_{6}{ }^{3+}$ & $3.09 \pm 0.28$ & $4.0^{\mathrm{f}}$ & 0.7458
\end{tabular}

a $25{ }^{\circ} \mathrm{C},\left[\mathrm{H}^{+}\right]=1.0 \times 10^{-2} \mathrm{M}$, and $\mu=0.20 \mathrm{M}$ maintained $w i t h$ sodium

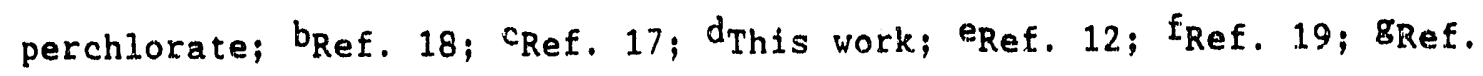
15. 
Table IV-2. Rate Constants ${ }^{a}$ for the oxidation of a series of $\mathrm{RCr}\left([15]\right.$ aneN $\left._{4}\right)\left(\mathrm{H}_{2} \mathrm{O}\right)^{2+}$ Complexes by $\mathrm{IrCl}_{6}{ }^{2-}$

\begin{tabular}{cc}
\hline$R$ & $k / 2 \mathrm{~mol}^{-1} \mathrm{~s}^{-1}$ \\
\hline $\mathrm{CH}_{3}$ & $2.20 \times 10^{-1}$ \\
$\mathrm{C}_{2} \mathrm{H}_{5}$ & $7.88 \times 10^{1}$ \\
$1-\mathrm{C}_{3} \mathrm{H}_{7}$ & $1.01 \times 10^{1}$ \\
$1-\mathrm{C}_{4} \mathrm{H}_{9}$ & $0.96 \times 10^{1}$ \\
$2-\mathrm{C}_{3} \mathrm{H}_{7}$ & $8.54 \times 10^{4}$ \\
$2-\mathrm{C}_{4} \mathrm{H}_{9}$ & $4.87 \times 10^{4}$ \\
$4-\mathrm{BrC}_{6} \mathrm{H}_{4} \mathrm{CH}_{2}$ & $1.29 \times 10^{4}$ \\
$\mathrm{C}_{6} \mathrm{H}_{5} \mathrm{CH}_{2}$ & $3.86 \times 10^{4}$ \\
$4-\mathrm{CH}_{3} \mathrm{C}_{6} \mathrm{H}_{4} \mathrm{CH}_{2}$ & $4.60 \times 10^{5}$ \\
\hline
\end{tabular}

a At $25{ }^{\circ} \mathrm{C},\left[\mathrm{H}^{+}\right]=1.0 \times 10^{-2} \mathrm{M}$ and $\mu=0.20 \mathrm{M}$, naintained $w$ ith $\mathrm{NaClO}_{4}$. 


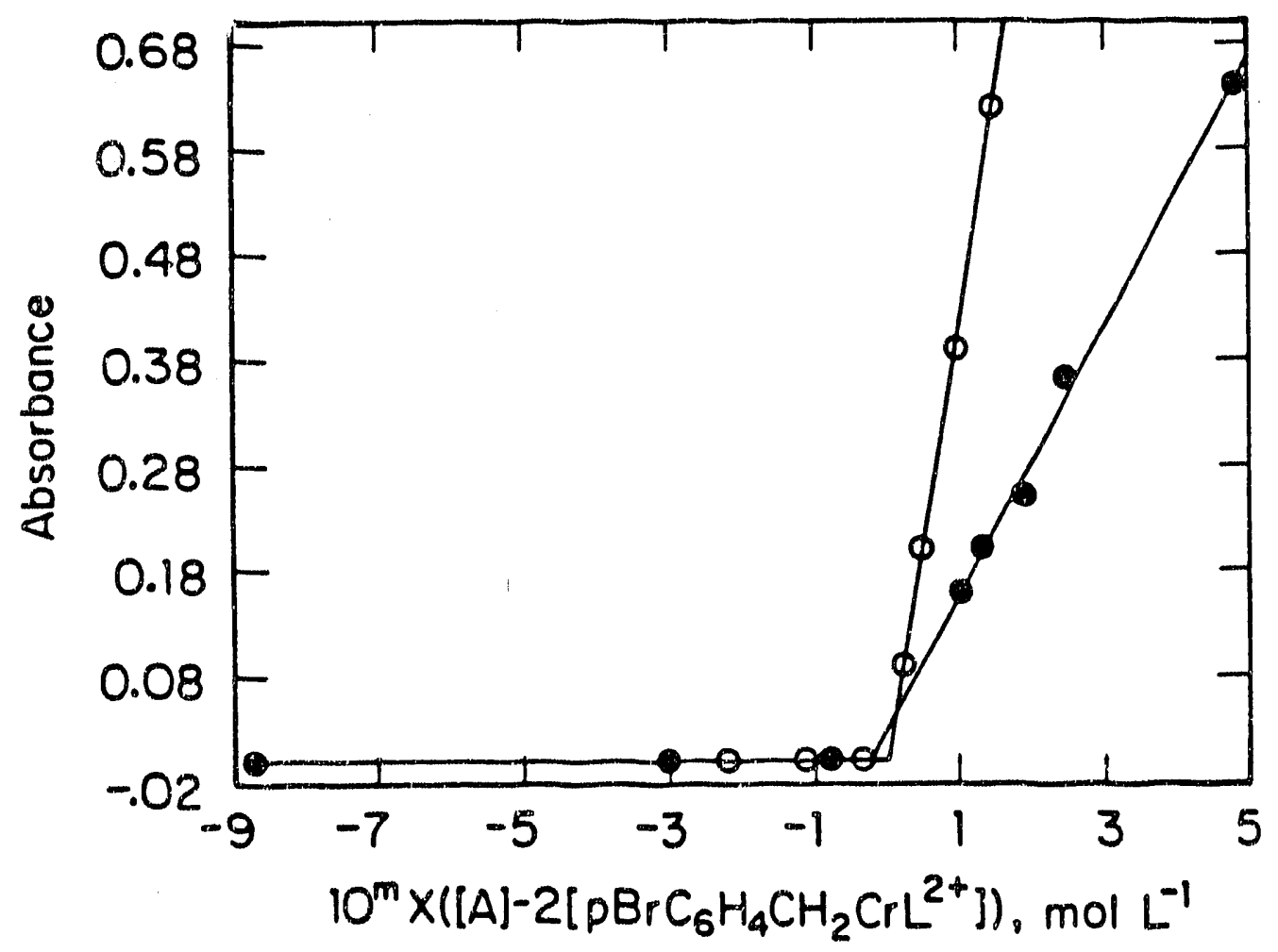

Figure IV-1. Spectrophotometric titrations of $4-\mathrm{BrC}_{6} \mathrm{H}_{4} \mathrm{CH}_{2} \mathrm{CrL}\left(\mathrm{H}_{2} \mathrm{O}\right)^{2+}$ by ABTS $^{\circ}$ - (A) (filled circles, $m=-4$ ) and $\mathrm{IrCl}_{6}{ }^{2-}$ (open circles, $m=-5$ ) showing $1: 2$ stoichiometry as in eq IV-2 to IV -4 


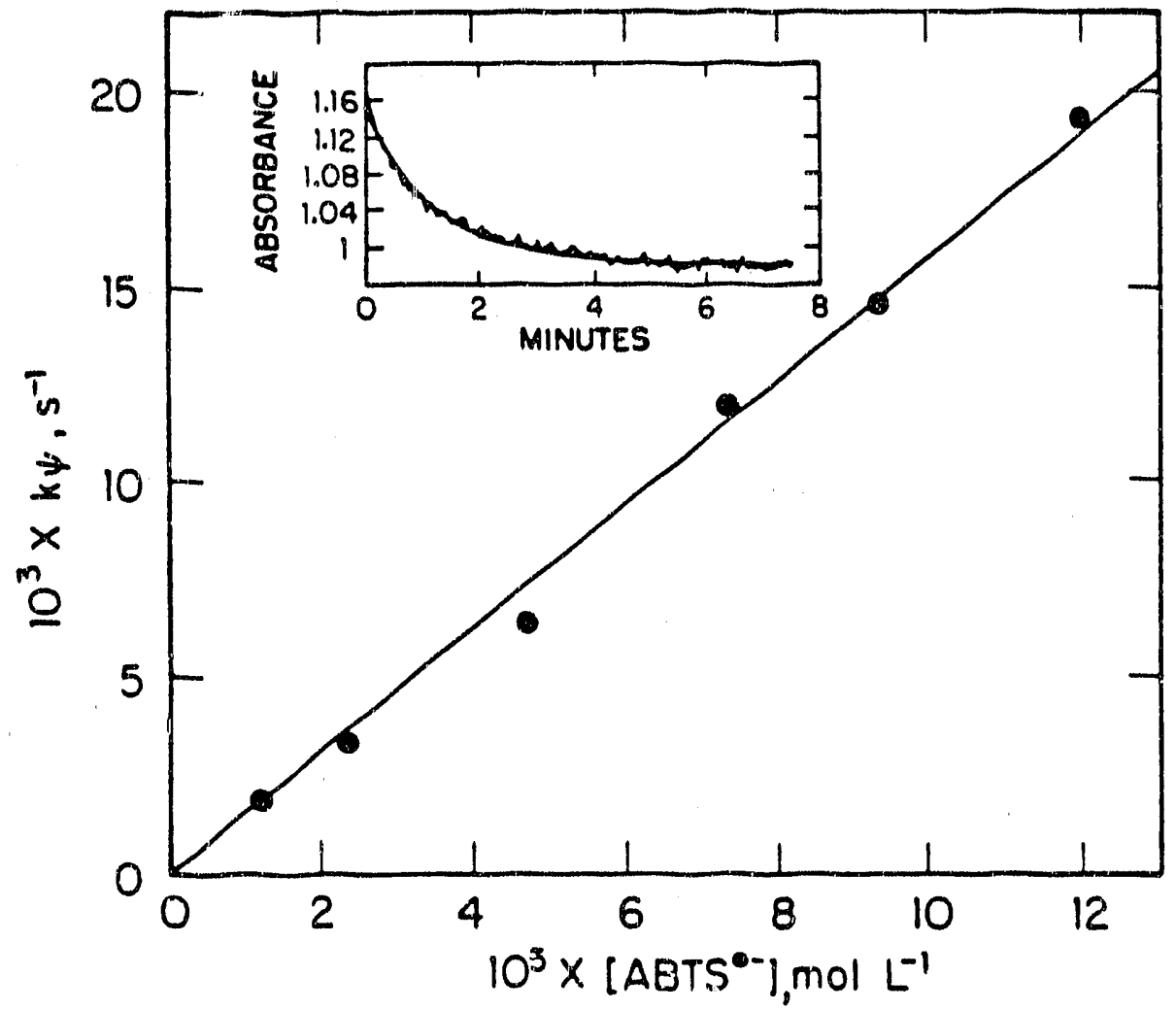

Figure IV-2. A plot showing the linear variation of kobsd with [ABTS - ] in experiments without added ABTs ${ }^{2-}$. The inset shows the kinetic trace and the least-squares fit to it, for an experiment with $\left[\text { ABTS }^{-}\right]_{0}=1.05 \times 10^{-4} \mathrm{M}$, $\left[4-\mathrm{BrC}_{6} \mathrm{H}_{4} \mathrm{CH}_{2} \mathrm{CrL}\left(\mathrm{H}_{2} \mathrm{O}\right)^{2+}\right]_{0}=6.0 \times 10^{-6} \mathrm{M},\left[\mathrm{H}^{+}\right]=1.0 \times 10^{-2}$ $\mathrm{M}$ at $\mu=0.20 \mathrm{M}$ and $25{ }^{\circ} \mathrm{C}$ 


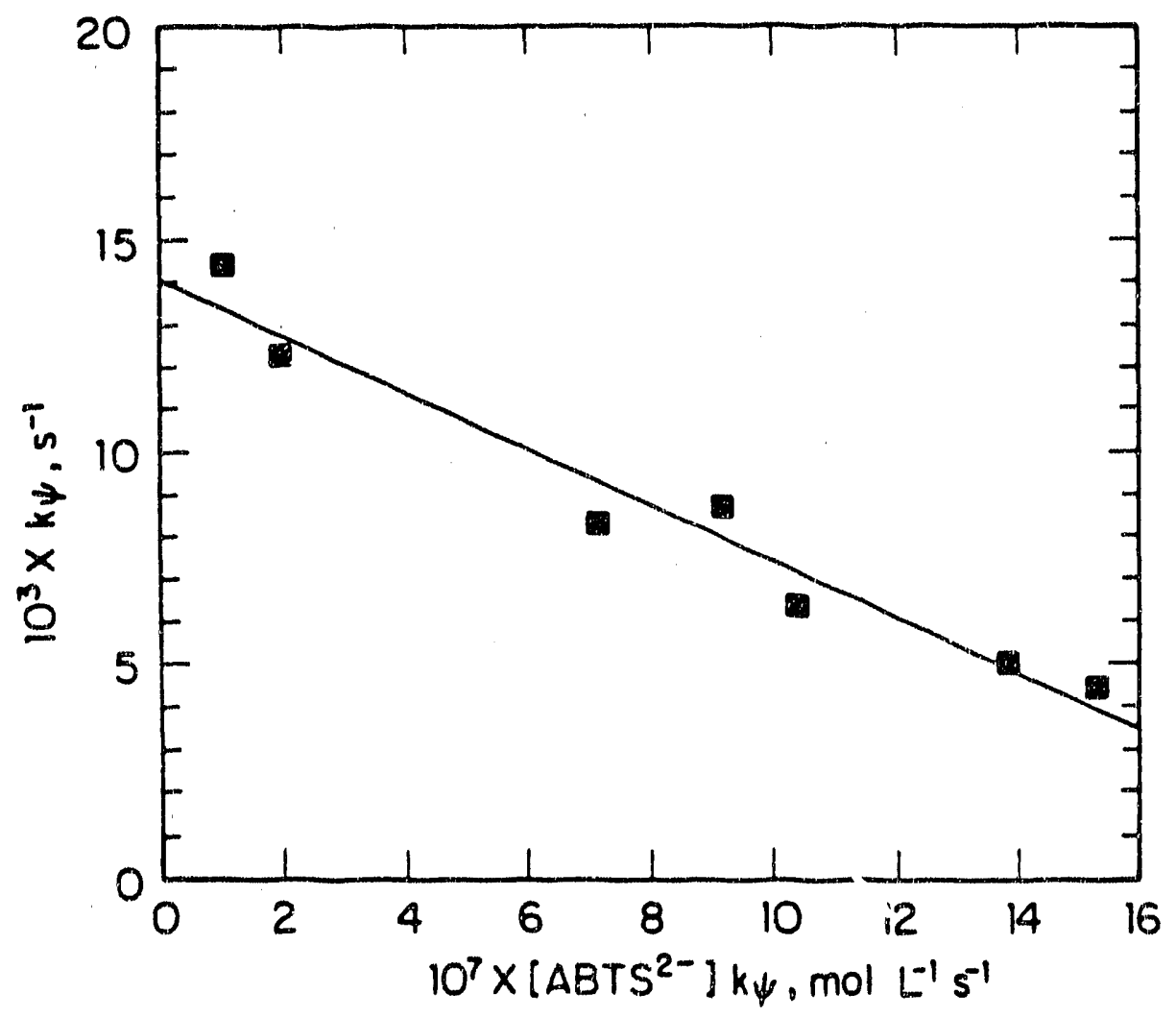

Pigure IV-3. The inhibiting effect of added $A B T S^{2-}$ is illustrated in a plot according to eq IV-6 


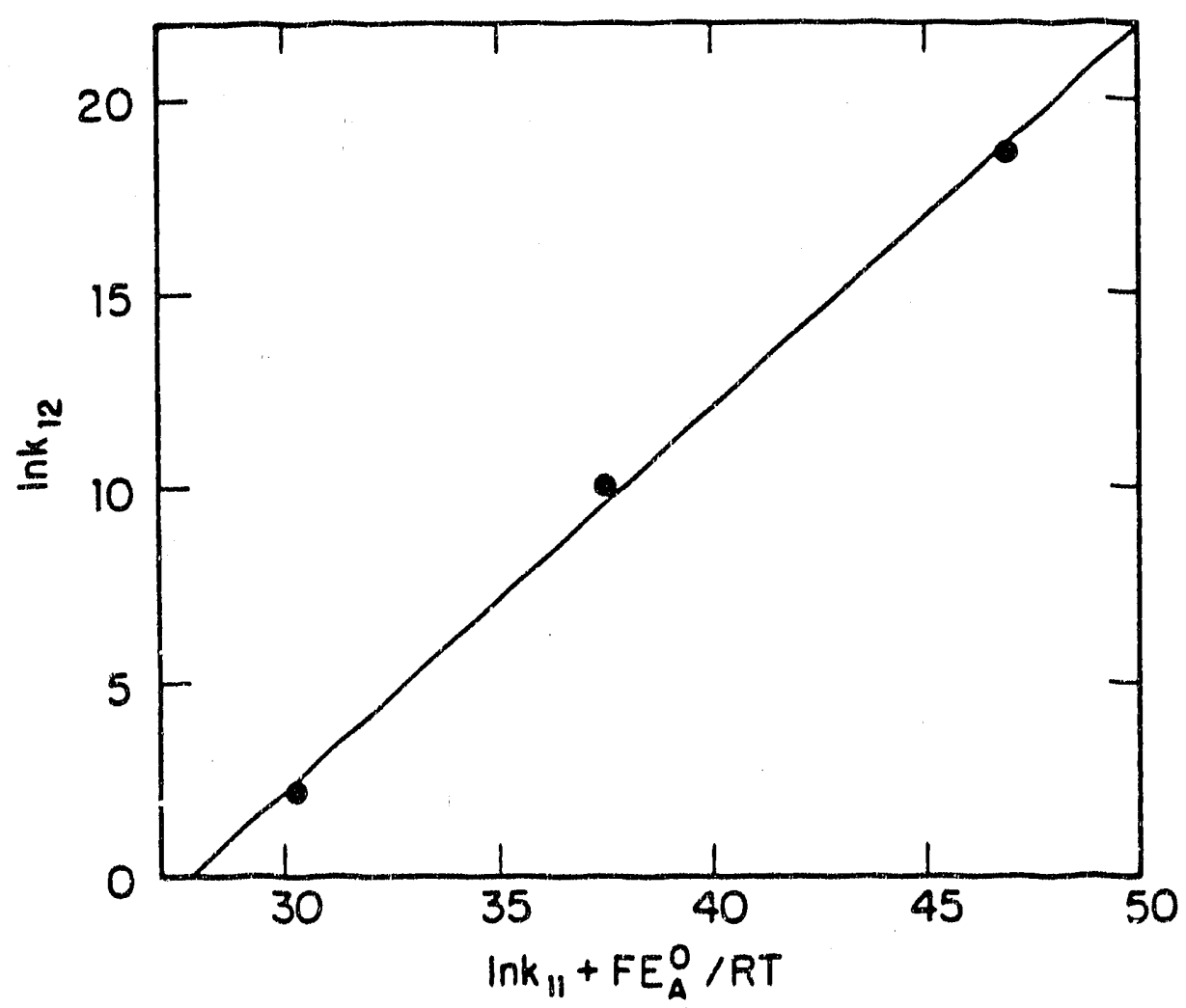

Pigure IV-4. A plot showing the analysis of the rate constant for oxidation of $4-\mathrm{BrC}_{6} \mathrm{H}_{4} \mathrm{CH}_{2} \mathrm{Crl} .\left(\mathrm{H}_{2} \mathrm{O}\right)^{2+}$ by $\mathrm{IrCl}_{6}{ }^{2-}$ according to the Marcus cross relation, eq IV-10. The ordinate is derived from the second-order rate constants (Table IV-2), and the abscissa scales the oxidizing ability of the oxidants (Table IV-1) 
REFERENCES

(1) Kochi, J. K. "Organometallic Mechanisms and Catalysis"; Academic Press: New York, 1978; Chapters 15-16.

(2) Katsuyama, T.; Bakac, A.; Espenson, J. H. Inorg. Chem. 1989, 28, 339.

(3) Melton, J. D.; Espenson, J. H.; Bakac, A. Inorg. Chem. 1986, 25, 4104.

(4) Melton, J. D.; Bakac, A.; Espenson, J. H. Inorg. Chem. 1986, 25, 3360 .

(5) The relevant potential is the one-electron potential of $\mathrm{Br}_{2}(\mathrm{aq}) / \mathrm{Br}_{2}{ }^{-}-, 0.5 \varepsilon \mathrm{V}$ (see ref. 6).

(6) Stanbury, D. M. Adv. Inorg. Chem. 1989, 33, 69-138.

(7) (a) Espenson, J. H.; Willlams, D. A. J. Am. Chem. Soc. 1974, 96, 1008; (b) Chang, J. C. ; Espenson, J. H. J. Chem. Soc. Commun. 1974, 233; (c) Espenson, J. H. ; Samuels, G. J. J. Organomet. Chem. 1976, 113,143 .

(8) $E^{0}=0.21 \mathrm{~V}$ for $I_{2}(a q)+e^{-}=I_{2} \cdot-6$

(9) Shi, S.; Espenson, J. H.; Bakac, A. J. Am. Chem. Soc. 1990, 112, 1346 .

(10) Samuels, G. J.; Espenson, J. H. Inorg. Chem. 1979, 18, 2587.

(11) Shi, S.; Espenson, J. H.; Bakac, A., Inorg. Chem。 1990, 29, 4318.

(12) Maruthamuthu, P.; Venkatasubramanian, L.; Dharmaling.3m, P. Bull. Chem. Soc. Jpn. 1987, 60, 113. 
(13) (a) Kelley, D. G.; Espenson, J. H.; Bakac, A. Inorg. Chem. 1990, 29, 0000; (b) Wolfender, B. S.; Willson, R. L. J. Chem. Soc. Per'. In Trans II 1982, 805; (c) Rush, J. D.; Koppenol, W. H. J. Am. Chem. Soc. 1988, 110, 4957; (d) Lindsay Smith, J. R.; Balasubramanian, P. N.; Bruice, T. C. J. Am. Chem. Soc. 1988 110, 7411; (e) MajkicSirgh, N.; Bogavac, L.; Kalimanovska, V.; Jelic, Z.; Spasic, S. Clinica Chimica Acta 1987, 162, 29; (f) Erben-kinss, M.; Michel, C.; Bors, W.; Saran, M. J. Enys. Chem. 1987, 91, 2362.

(14) Steenken, S.; Neta, P. J. Am. Chem. Soc. 1982, 104, 1244.

(15) (a) Yee, E. L.; Cave, R. J.; Guyer, K. L.; Tyma, B. D.; Weaver, M. J. J. Am. Chem. Soc. 1979, 101, 1131; (b) Weaver, M. J.; Yee, E. L. Inorg. Chem. 1980, 19, 1936.

(16) Nohr, R. S.; Espenson, J. H. J. Am. Chenl. Soc. 1975, 97, 3392,

(17) Margerum, D. W.; Chellappa, K. L.; Bossu, F. P.; Burce, G. L. J. Am. Chem. Soc. 1975, 97, 6894.

(18) Hurwitz, P.; Kustin, K. Trans. Faraday Soc. 1966, 62, 427.

(19) Silverman, J.; Dodson, K. W. J. Phys. Chem. 1952, 56, 816.

(20) Halpern, J.; Chan, M. S.; Hanson, J.; Roche, T. S.; Topich, J. A. J. Am. Chem. Soc. 1975, 97, 1606.

(21) Halpern, J.; Topich, J.; Zamaraev, K. I. Inorg. Chim. Acta 1976, 20, L21.

(22) Topich, J.; Halpern, J. Inorg. Chem. 1979, 18, 1339.

(23) Halpern, J.; Chan, M. S.; Roche, T. S.; Tom, G. M. Acta Chem. Scand. A $1979,33,141$.

(24) Anderson, S. N.; Ballard, D. H.; Chrzastowski, J. Z.; Dodd, D.; Johnson, M. D. J. Chem. Soc. Chem. Commun. 1.972, 685. 
(25) Anderson, S. N.; Ballard, D. H.; Johnson, M. D. J. Chem. Soc. Perkin Trans. 2 1972, 311.

(26) Jensen, F. R.; Madan, V.; Buchanan, D. H. J. Am. Chem. Soc. 1971, 93, 5283 . 
101

PART V. REDUCTION INDUCED COBALT-CARBON BOND CLRAVAGE IN ORGANOCOBALT MACROCTCLIC COMPLEXES 


\section{INTRODUCTION}

Reduction induced cleavage of cobalt-carbon bond in organocobalt macrocyclic complexes presents challenging questions. Detailed mechanistic and kinetic information is still insufficient to understand fully the roles of $v^{2} t a m i n B_{12}$ in the catalysis of reactions such as skeletal 1,2-rearrangements, 1,2 reduction of ribonucleoside triphosphates, 3-5 and biosynthesis of methionine, 6,7 methane, $8-11$ and acetate. $10,12-14$ A new domain of chemistry studying reactivities of "partial-strength" M-C o-bonds, namely the reactivities of $\mathrm{H}-\mathrm{C}$ bonds in complexes containing one or more electrons in antibonding orbitals, begins to emerge. 15

The electrochemical reduction of alkylcobalt(III) compounds generally gives unstable alkylcobalt anions which decompose by the cleavage of the Co-C bond. Both homolytic and heterolytic decomposition pathways were reported to be operative after one electron reduction.16-21 For example, in the case of $\mathrm{RCo}^{\mathrm{II}}$ (salen)-, when $\mathrm{R}=\mathrm{C}_{6} \mathrm{H}_{5}{ }^{16-18}$ or fluoroalkyl, 1.9 the

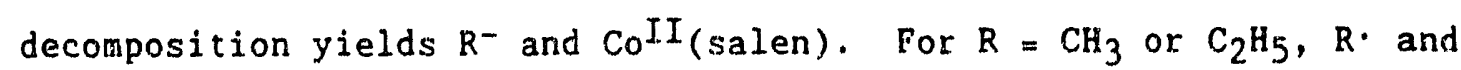
$\mathrm{Co}^{\mathrm{I}}$ (Salen)- are produced.17,20 These two decomposition mechanisms were also observed for the bond cleavage induced by chemical reduction. 22-27

It has been noticed in some cases that the equatorial ligand may play an active part in the reduction induced cleavage of the Co-C bond. A reversible trapping of the alkyl group by the equatorial ligands was proposed to account for the c.a. $60-80 \%$ recovery of the starting organocobalt(III) complexes and for the retention of configuration of the alkyl group after one-electron reduction followed ty re-oxidation. 28 The 
electrochemical reductive cleavage of a steroidal cobalt porphyrin complex proceeds with retention of configuration. 29,30

Norwithstanding the wealth of information about the reduction potentials, 21 little is known about the reduction and decomposition kinetics, 15 about the electron configuration of the reduced organocobalt intermediates and about the mechanisms by which the equatorial ligands participate in the reduction induced cleavage of the Co-C bond.

We wish to present here the results of our investigation on a series of organocobalt macrocyclic complexes, $\mathrm{RCo} I I I\left(d m g B F_{2}\right)_{2} \mathrm{~A}$, where $\mathrm{R}=\mathrm{CH}_{3}$, $\mathrm{C}_{2} \mathrm{H}_{5}, \quad 1-\mathrm{C}_{3} \mathrm{H}_{7}, 4-\mathrm{BrC}_{6} \mathrm{H}_{4} \mathrm{CH}_{2}, \mathrm{C}_{6} \mathrm{H}_{5} \mathrm{CH}_{2}, 4-\mathrm{CH}_{3} \mathrm{C}_{6} \mathrm{H}_{4} \mathrm{CH}_{2}$ and $\mathrm{A}=\mathrm{py}, \mathrm{H}_{2} \mathrm{O}$ and $\mathrm{OH}^{-}$. We will focus on the following issues: (1) The mechanisms of reduction induced decompositions of organocobalt complexes. (2) The electron configuration of $\left.\left.\mathrm{RCoII}^{(\mathrm{dmgBF}}\right)_{2}\right)^{-}$and the reason that the Co-C bond in these reduced species does not decompose immediately after reduction. Participation of the equatorial ligand, especially the possibility of the alkyl group transfer and hydrogen atom transfer to the equatorial ligand. (4) Reaction kinetics. 
EXPERIMENTAL SECTION

Naterials. Organocobalt(III) macrocyclic complexes, $\left.\mathrm{RCo}(\mathrm{dmgBF})_{2}\right)_{2} \mathrm{~A}$ (A $=\mathrm{py}, \mathrm{H}_{2} \mathrm{O}$ ) were synthesized from $\mathrm{RCo}(\mathrm{dmgH})_{2} \mathrm{~A}$ and $\mathrm{BF}_{3}$ according to the known methods, 31 and recrystallized from acetone. All the complexes had satisfactory elemental analysis, UV-Vis spectra, 32 and $1_{\text {H-NMR. }} 32$ Inorganic cobalt(II) macrocyclic complexes, $\mathrm{Co}(\mathrm{dmgH}){ }_{2} \mathrm{~A}_{2}$, wexe prepared by a literature method. 33 Nickel tetramethylcyclam, R, S,R, S-Ni(tmc) $)^{2+}(\mathrm{tmc}=$ $1,4,8,11$-tetramethy $1-1,4,8,11$-tetraazacyclotetradecane), was prepared by a known procedure. 34 other reactants and solvents were obtained commercially and often used without further purification.

Blectrochemical Reduction. Voltammetric experiments were conducted at room temperature in acetonitrile with $0.06 \mathrm{M} \mathrm{Me}_{4} \mathrm{NBF}_{4}$ (Aldrich) as the supporting electrolyte. It was performed on a BAS-100 electrochemical analysis system with a glassy-carbon working electrode, a platinum wire auxiliary electrode, and a $\mathrm{Ag} / \mathrm{AgCl}(3 \mathrm{M} \mathrm{NaCl})$ reference electrode. Controlled potential electrolysis of $\mathrm{RCo}\left(\mathrm{dmgBF}_{2}\right)_{2} \mathrm{~A}$ for product analysis was conducted in $0.06 \mathrm{M} \mathrm{Me}_{4} \mathrm{NBF}_{4}$ of either dry acetonitrile or acetonitrile-water solution and performed on a BAS CV-27 voltammograph with a Hg-pool working electrode, a platinum nlate allxiliary electrode, and a $\mathrm{Ag} / \mathrm{AgCl}(3 \mathrm{M} \mathrm{NaCl})$ reference electrode. Electrochemical preparation of $\mathrm{Ni}(\mathrm{tmc})^{+}$was achieved by controlled potential reduction of $\mathrm{Ni}(\mathrm{tmc})^{2+}$ in aqueous solution containing $0.08 \mathrm{M} \mathrm{LiClO}_{4}$ and $0.02 \mathrm{M} \mathrm{NaOH} .35$ oxygen free conditions were maintained by Ar atmosphere. 
Product Analysis. The organic decomposition products were detected by GC and GC-mass spectroscopic techniques. The GC detection was performed on a Hewlett-Packard Model 5790 gas chromatograph with $6^{\prime}$ columns packed either with VZ-10 or $0 \mathrm{~V}-101$ as stationary phases. The instrument was calibrated by use of commercial organic compounds. The GC-mass spectra of the decomposition products of $\mathrm{C}_{3} \mathrm{H}_{7} \mathrm{Co}\left(\mathrm{dmgBF}_{2}\right)_{2}$ - were obtained on a Finnigan 4500 GC-mass spectrometer interfaced to the Incos data system. Cooling with liquid $\mathrm{N}_{2}$ (for $1.5 \mathrm{~min}$ ) was employed to separate the organic molecules to be detected from gaseous impurities. A $30 \mathrm{~m}$ DB 624 capillary column was used for chromatographic separation before mass detection. In addition, the different relative abundance of mass $=41$ peak over mass $=$ 42 peak could be taken advantage of to detect cyclopropane in the presence of propene. For propene, abundance of mass $=41>$ abundance of mass $=42$; for cyclopropane, the opposite is true. 36 Therefore the decomposition products, propane, propene, and cyclic propane, can be detected individually from reaction mixture by a GC-mass spectrometer. The inorganic decomposition products were detected by their electronic spectra, 37 and reduction potentials.

Spectroscopic studies. The ${ }^{1} \mathrm{H}-\mathrm{NMR}$ and ${ }^{13} \mathrm{C}$-NMR studies were conducted. in DMSO-d 6 solution at room temperature cul Nicnlet-30ก MHz and Bruker WM$200 \mathrm{MHz}$ nuclear magnetic resonance spectrometers. The ESR spectra were collected on an IBM/Brucker ER-200 electron paramagnetic resonance spectrometer at $100 \mathrm{~K}$. The electronic spectra were obtained on a Cary-219 and a Perkin-Elmer Lambda Array UV-vis spectrometer. 
Rinetics. The kinetics of the reaction between $\mathrm{RCo}(\mathrm{dmgBF} 2)_{2} \mathrm{OH}^{-}$and $\mathrm{Ni}(\mathrm{tmc})+$ was studied at $25.0 \pm 0.1^{\circ} \mathrm{C}$ in $0.7 \%$ acetone aqueous solution with ionic strength of $0.1 \mathrm{M}$ controlled by $\mathrm{NaClO}_{4}$, and $\mathrm{pH} 12$ controlled by NaOH. The reaction process was monitored at $\lambda=610 \mathrm{~nm}$ by a Durrum-Dionex stopped-flow spectrometer. The same instrument was used for fast repetitive scans of the electronic spectra. All the experiments were conducted under an argon atmosphere owing to the sensitivity of $\mathrm{Ni}(\mathrm{tmc})^{+}$ and reduced cobalt species towards oxygen. Concentrations of reactants were determined spectrophotometrically, 32, 35 
RESULTS

Reduction Induced Decompositions. The cyclic voltammogram for the one electron reduction of the trans aquaorganocobalt(III) macrocyclic complexes, $\mathrm{RCo}\left(\mathrm{dmgBF}_{2}\right){ }_{2} \mathrm{~A}, \quad\left(\mathrm{R}=\mathrm{CH}_{3}, \mathrm{C}_{2} \mathrm{H}_{5}, 1-\mathrm{C}_{3} \mathrm{H}_{7}, 4-\mathrm{BrC}_{6} \mathrm{H}_{4} \mathrm{CH}_{2}, \mathrm{C}_{6} \mathrm{H}_{5} \mathrm{CH}_{2}\right.$, 4- $\mathrm{CH}_{3} \mathrm{C}_{6} \mathrm{H}_{4} \mathrm{CH}_{2} ; \mathrm{A}=\mathrm{py}, \mathrm{H}_{2} \mathrm{O}$ ) exhibits one cathodic wave and two anodic waves in the first scan and two cathodic waves and two anodic waves in the following scans in the range 0 to $-1.2 \mathrm{~V}$ (vs $\mathrm{Ag} / \mathrm{AgCl}_{\mathrm{E}}$ ), yielding $\mathrm{E}_{1 / 2}-0.5$ $\mathrm{V}$ and $\mathrm{E}_{1 / 2}(1) \mathrm{ca} .-1.0 \mathrm{~V}$, as shown in Pigure V-1a. A control experiment under identical conditions but with $\left.\mathrm{CoII}_{(\mathrm{dmgBF}}\right)_{2}\left(\mathrm{H}_{2} \mathrm{O}\right)_{2}$ replacing $\mathrm{RCo}^{\mathrm{III}}(\mathrm{dmgBF})_{2}\left(\mathrm{H}_{2} \mathrm{O}\right)$ afforded a cyclic voltammogram containing only one reduction wave and one oxidation wave, at $E_{1 / 2}-0.5 \mathrm{~V}$, as shown in Figure V-1b. A blank experiment under identical conditions but in the absence of cobalt species showed no redox wave in this region.

Changing the trans group from $\mathrm{H}_{2} \mathrm{O}$ to py introduces no additional feature except for a slight shift of the reduction wave $(0.01$ to $0.03 \mathrm{~V})$ towards more negative value. An increase of scan rate makes the oxidation wave at ca. $-1.0 \mathrm{~V}$ better developed, but the overall voltammogram was less reversible.

The fate of the one electron reduction product $\mathrm{RCo}\left(\mathrm{dmgBF}_{2}\right)_{2}-38 \mathrm{hos}$ studied by analyzing its decomposition products. For $\mathrm{R}=\mathrm{CH}_{3}$, only $\mathrm{CH}_{4}$ was detected after one electron reduction. For $\mathrm{R}=\mathrm{C}_{2} \mathrm{H}_{5}$ and $1-\mathrm{C}_{3} \mathrm{H}_{7}$, both $\mathrm{RH}$ and $\mathrm{R}(-\mathrm{H})$ were detected. No $R_{2}$ was found in any circumstances. In the case of primary alkylcobalt complexes, the $\mathrm{RH} / \mathrm{R}(-\mathrm{H})$ ratio increases with the water content in the solvent, Table $v-1$. Reduction of $R C o\left(d m g B F_{2}\right)_{2} A$ 
cculd also be accomplished chemically over $\mathrm{Zn}(\mathrm{Hg})\left(E_{1 / 2}=-0.76 \mathrm{v}^{39}\right)$ and with $\mathrm{Ni}(\mathrm{tmc})^{+}\left(E_{1 / 2}=-0.87 \mathrm{v}^{35}\right)$.

About $1 \%$ cyclopropane was detected in the head gas on an aqueous solution of $1-\mathrm{C}_{3} \mathrm{H}_{7} \mathrm{Co}(\mathrm{dmgBF})_{2}$ py reduced by $\mathrm{Zn}(\mathrm{Hg})$. Propane and propene constitute $99 \%$ of the organic decomposition products.

The short-lived $\mathrm{RCo}\left(\mathrm{dmgBF}_{2}\right)_{2}-$ can be captured by quenching its decomposition in liquid $\mathrm{N}_{2}$ immediately after its formation as signaled by visible color change of the solution from bright yellow (parent $\left.\mathrm{RCo}^{\mathrm{ITI}}\left(\mathrm{dmgBF}_{2}\right)_{2} \mathrm{~A}\right)$ to dark green upon one electron reduction. The low temperature $(100 \mathrm{~K})$ ESR spectrum of this frozen dark green solution shows an unprecedented $d^{7}$ cobalt electron resonance pattern with $g_{\|}=2.23, g_{\perp}=$ 2.07, $A_{\|}=106.4 \mathrm{G}$, and $A_{\perp}=56 \mathrm{G}$, as shown in Figure V-2. This ESR spectrum disappears and replaced by that of $\mathrm{CoII}^{\mathrm{II}}(\mathrm{dmgBF})_{2}\left(\mathrm{H}_{2} \mathrm{O}\right)_{2}{ }^{37}$ if the dark green solution is allowed to warm to room temperature and then cooled to $100 \mathrm{~K}$ again. No room temperature ESR was observed.

Participation of the Equatorial Ligand. Reduction of $1-\mathrm{C}_{3} \mathrm{H}_{7} \mathrm{Co}\left(\mathrm{dmgBF}_{2}\right)_{2}$ py by excess $\mathrm{NaBH}_{4}$ in $\mathrm{DMSO}_{-} \mathrm{d}_{6}$ yielded a deep blue solution. Both $\mathrm{C}_{3} \mathrm{H}_{8}$ and $\mathrm{C}_{3} \mathrm{H}_{6}$ were detected in the head gas with $\mathrm{C}_{3} \mathrm{H}_{8} / \mathrm{C}_{3} \mathrm{H}_{6}=0.25$. Reduction of $\mathrm{CH}_{3} \mathrm{Co}\left(\mathrm{dmgBF}_{2}\right)_{2}$ py by excess $\mathrm{NaBH}_{4}$ afforded a similar deep blue solution with $\mathrm{CH}_{4}$ detected as the only gaseous product. The deep blue solutions of reduced organocobalt complexes so obtained $\left(\mathrm{R}=\mathrm{CH}_{3}, \mathrm{C}_{3} \mathrm{H}_{7}, \mathrm{C}_{6} \mathrm{H}_{5} \mathrm{CH}_{2}\right)$ are diamagnetic exhibiting no ESR signal but well define ${ }^{1} \mathrm{H}-$, and ${ }^{13} \mathrm{C}-\mathrm{NMR}$ spectra.

The ${ }^{1} \mathrm{H}-\mathrm{NMR}$ spectrum in DMSO-d 6 of such a solution of $\mathrm{CH}_{3} \mathrm{Co}\left(\mathrm{dmgBF}_{2}\right)_{2}$ py $/ \mathrm{NaBH}_{4}$ (excess) shows a set of four new resonance peaks at $1.90 \mathrm{ppm}(3 \mathrm{H}$, 
broad), $2.01 \mathrm{ppm}(3 \mathrm{H}), 2.04 \mathrm{ppm}(3 \mathrm{H}), 2.10 \mathrm{ppm}$ (10H) as compared to the $1_{\mathrm{H}-\mathrm{NMR}}$ spectrum of $\mathrm{Co}\left(\mathrm{dingBF}_{2}\right)_{2}(\mathrm{py})_{2}$ reduced by excess $\mathrm{NaBH}_{4}$ in $\mathrm{DMSO} \mathrm{d}_{6}$ (a singlet at $1.75 \mathrm{ppm}$ ), as depicted in Figure V-3a. The borohydride resonances centered at ca. $-0.35 \mathrm{ppm}$ as a quartet (from $11_{\mathrm{B}-\mathrm{H}}$ ) accompanied by a set of seven peaks of much less total intensity (from 10 $B-H$ ) as well as the resonance of the pyridine hydrogen at lower field (ca. $7.50 \mathrm{ppm}$ ) are well separated from the methyl hydrogen resonances and do not interfere. Peaks at $2.04,2.01$, and $1.90 \mathrm{ppm}$ are of comparable intensity and were assigned to the methyl group of the reduction product. The peaks at 2.10 and $1.75 \mathrm{ppm}$ correspond to the one electron reduction products of $\left.\mathrm{Co}(\mathrm{dmgBF})_{2}\right)_{2}\left(\mathrm{H}_{2} \mathrm{O}_{2}\right.$ and $\mathrm{Co}\left(\mathrm{dmgBF}_{2}\right)_{2}(\mathrm{py})_{2}$ in DMSO respectively. Variation of magnetic field strength from $200 \mathrm{MHz}$ to $300 \mathrm{MHz}$ did not change the chemical shifts of these peaks, indicating that they are independent resonance peaks rather than components of a multiplet.

The ${ }^{13} \mathrm{C}$-NMR spectrum of the $\mathrm{CH}_{3} \mathrm{Co}(\mathrm{dmgBF})_{2}$ py / $\mathrm{NaBH}_{4}$ (excess) solution exhibits a set of peaks at $10.9 \mathrm{ppm}$ to $23.8 \mathrm{ppm}$, which are due to the methyl and imine carbons, Figure V-3b. The resonances of pyridine carbons centered at ca. $140 \mathrm{ppm}$ do not interfere with those.

Kinetics of the Reduction of $\mathrm{RCo}\left(\mathrm{dmgBP}_{2}\right)_{2} \mathrm{~A}$ by $\mathrm{Ni}(\mathrm{tmc})^{+}$. The reaction between $\mathrm{RCo}\left(\mathrm{dmgBF}_{2}\right)_{2} \mathrm{py}$ and $\mathrm{Ni}(\mathrm{tmc})^{+}$generates the blue cobalt(I), as shown by the repetitive scans of Figure V-4. Both ethane and ethylene were detected in the head gas after the reaction between $\mathrm{C}_{2} \mathrm{H}_{5} \mathrm{Co}(\mathrm{dmgBF})_{2}$ py and $\mathrm{Ni}(\mathrm{tmc})^{+}$was complete. The $\mathrm{C}_{2} \mathrm{H}_{6} / \mathrm{C}_{2} \mathrm{H}_{4}$ ratio decreases as the proportion of $\mathrm{CH}_{3} \mathrm{CN}$ as co-solvent increases. This ratio also decreases as the $\mathrm{Ni}(\mathrm{tmc})^{+} / \mathrm{C}_{2} \mathrm{H}_{5} \mathrm{Co}(\mathrm{dmgBF})_{2}$ py ratio decreases. When 
$R=$ primary alkyl, the reaction proceeds according to a simple mixed second order rate law, eq $\mathrm{V}-1$,

$$
\begin{aligned}
& \frac{\left.d \cdot \mathrm{Co}^{I}(\mathrm{dmgBF})_{2} \mathrm{py}\right]}{\mathrm{dt}}=\frac{\left.-\mathrm{d}\left[\mathrm{RCo}^{I I I}(\mathrm{dmgBF})_{2}\right)_{2 y}\right]}{d t} \\
& =k_{e, 1}\left[\mathrm{RCo}(\mathrm{dmgBF})_{2}\right]\left[\mathrm{Ni}(\mathrm{tmc})^{+}\right]
\end{aligned}
$$

The reaction rate constant, $k_{e}, 1$, as defined by eq $V-1$ and evaluated with excess $\mathrm{Ni}(\mathrm{tmc})^{+}$, is independent of acetone concentration ( $0 \%$ to $3.8 \%$ ), independent of $\mathrm{pH}(\mathrm{pH} 11-12)$ and independent of $\left[\mathrm{Ni}(\mathrm{tmc})^{2+}\right]$. A kinetic trace and a plot of $k_{\text {obs }}$ vs. $\left[\mathrm{Ni}(\mathrm{tmc})^{+}\right]$are shown in Figure V-5. The $\mathrm{k}_{\mathrm{e}, 1}$ values are listed in Table $\mathrm{V}-2$.

When $\mathrm{R}=$ aralkyl, the reaction proceeds in two steps with a biphasic kinetic trace, implying accumulation of a reduction intermediate, Figure V-6. The fast phase is well separated from the slow one and both follow a pseudo-first oxder vate law and both show a first order dependence on $\left[\mathrm{Ni}(\mathrm{tmc})^{+}\right]$, Figure $\mathrm{V}-7 \mathrm{a}, \mathrm{b}$. The second order rate constants, $k_{e, 1}$ and $k_{e, 2}$ were obtained by plotting $k^{\prime}$ obs and $k^{\prime \prime}$ obs against [Ni(tmc $)^{+}$]; here $k^{\prime}$ obs and $k$ "obs were obtained from traces of the fast and the slow phase respectively. 


\section{DISCUSSIONS}

Reduction Induced Decompositions. The cyclic voltammagram of the one electron redox process measured at room temperature shows a quasireversible character, $I_{a}<I_{c}$ (Figure $V-1 a$ ), indicating that follow-up chemical reactions aistroy the electrochemically generated RCo(dmgBF $)_{2}-21$ This EC mechanism is lilustrated by eq $V-2$, to $V-4$.

$$
\begin{aligned}
& \left.\mathrm{RCo}(\mathrm{dmgBF})_{2}{ }_{2} \mathrm{~A}+\mathrm{e}^{-} \rightarrow\left[\mathrm{RCo}(\mathrm{dmgBF})_{2}\right)_{2} \mathrm{~A}^{-}\right] \\
& {\left[\mathrm{RCo}(\mathrm{dmgBF} 2)_{2} \mathrm{~A}^{-}\right]+2 \mathrm{H}_{2} \mathrm{O} \rightarrow \mathrm{RH}+\mathrm{Co}(\mathrm{dmgBF} 2)_{2} \mathrm{~A}\left(\mathrm{H}_{2} \mathrm{O}\right)+\mathrm{OH}^{-}} \\
& {\left[\mathrm{RCo}(\mathrm{dmgBF})_{2} \mathrm{~A}^{-}\right] \rightarrow \mathrm{R}(-\mathrm{H})+\mathrm{Co}(\mathrm{dmgBF})_{2}\left(\mathrm{H}_{2} \mathrm{O}\right) \mathrm{A}^{-}}
\end{aligned}
$$

We believe that hydrolysis (eq V-3) and B-hydrogen elimination (eq V-4) as opposed to the simple $\mathrm{C}-\mathrm{Co}$ (II) bond homolysis 21 constitute of the major pathways of the reduction induced decomposition of these organocobalt complexes. This is because the detected $\mathrm{RH} / \mathrm{R}(-\mathrm{H})$ ratio deviates significantly from unity and varies with water content of the solvent. This is also because that no radical coupling product $\mathbb{R}_{2}$ is detected in head gas.

Slow hydrolysis of a C-Co(III) bond was observed before. $40-42$

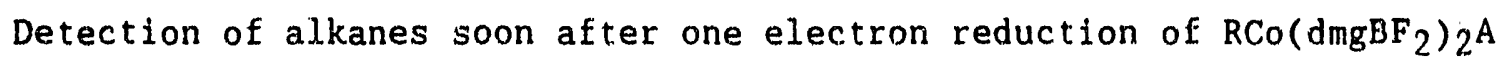
signals a more ready hydrolysis of a $\mathrm{C}-\mathrm{Co}(\mathrm{II})$ bond in $\mathrm{RCo}(\mathrm{dmgBF} 2)_{2} \mathrm{~A}^{-}$. One could speculate that the alkyl group in $\mathrm{RCo}\left(\mathrm{dmgBF}_{2}\right)_{2}-$ possesses higher electron density and nence renders the C-Co bond more subject to hydrolysis. Theoratically, since the homolysis can be viewed as an intramolecular electron transfer from carbanion to cobalt, any factor 
that lowers the LuMO level on cobalt will increase the homolysis rate and vice versa. Thus it is easily understood why reduction promotes heterolysis and oxidation promotes homolysis. It is known experimentally that oxidation of organocobalt(III) complexes does accelerate homolysis of the C-Co bond. 43,44

Rather unexpectedly, an oxidized organic compound, $R(-H)$, is formed upon reduction of $\mathrm{RCo}\left(\mathrm{dmgBF}_{2}\right)_{2} \mathrm{~A}$. Since $\mathrm{R}(-\mathrm{H})$ is not formed from an alkyl radical, the formation of $\mathrm{R}(-\mathrm{H})$ could only be realized by further reduction of the cobalt macrocycle fragment. B-H elimination is a plausible pathway leading to $R(-H)$ from $R C o\left(d m g B F_{2}\right)_{2}-$. It seems quite unlikely for cobalt center to serve as the hydrogen acceptor in the $\beta-H$ elimination, since no adjacent coordination vacancy is available. In addition, no precedent of cobalt(II) hydride is known. 
Participation of the Equatorial Ligand. We propose the following scheme to accommodate our observations.

Scheme 1

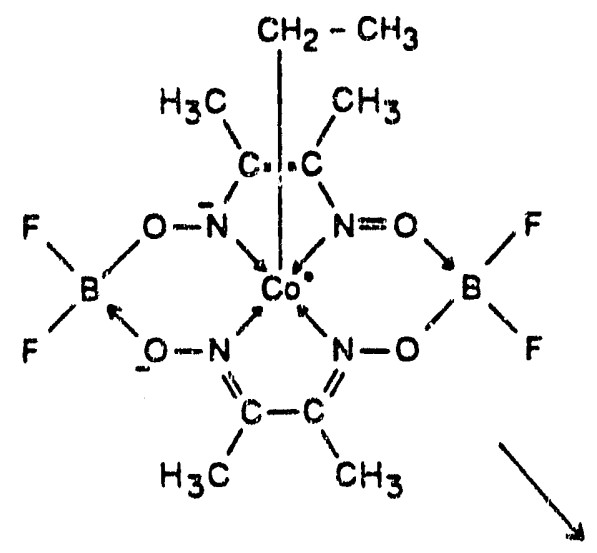

$$
\mathrm{CH}_{2}=\mathrm{CH}_{2}
$$

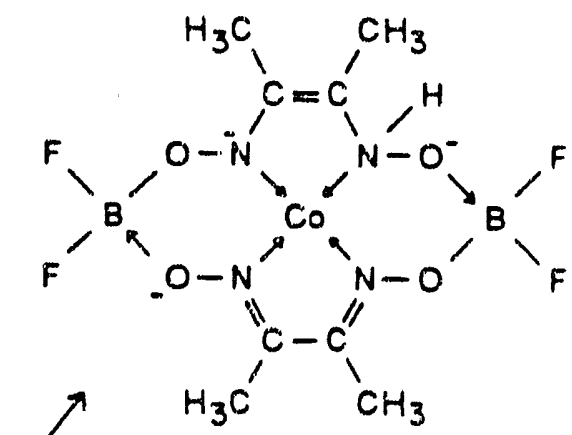

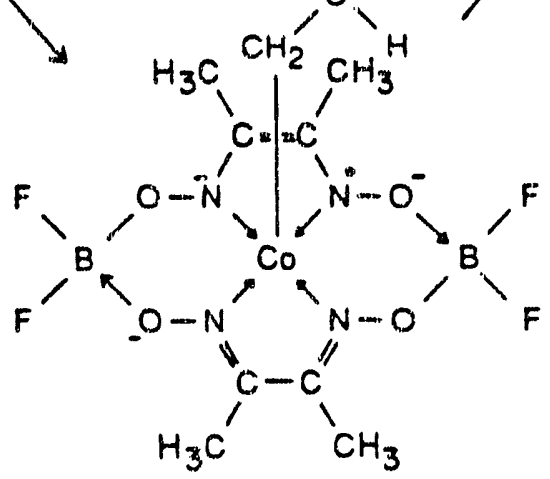

Scheme 1 suggests that the oxidation of the alkyl group to alkene is accomplished by reduction of the equatorial ligand. The cobalt center plays a role to mediate the intramolecular hydrogen atom transfer. Participation of conjugated macrocyclic ligand in the formation and cleavage of $\mathrm{C}-\mathrm{Co}(\mathrm{II})$ bond was proposed before, $28-30,45$ and observed in the decomposition of a $\mathrm{CH}_{3}-\mathrm{Co}$ (III) bond. 46

The $\mathrm{Y}-\mathrm{H}$ elimination product of $\mathrm{C}_{3} \mathrm{H}_{7} \mathrm{Co}\left(\mathrm{dmgBF}_{2}\right)_{2} \mathrm{py}^{-}, \mathrm{C}-\mathrm{C}_{3} \mathrm{H}_{6}$, was also detected (ca. $1 \%$ ) in the head gas. It seems likely that both $\beta-H$ and $\gamma-H$ eliminations operate by the same mechanism, i.e., hydrogen transfer from 
the axial alkyl to the equatorial ligand. Steric factors favor B-H elimination over $\gamma$-H elimination.

In the absence of $\beta$ - and $\gamma$-hydrogens, migration of alky 1 group to the equatorlal ligand is expected. The ${ }^{1} \mathrm{H}-\mathrm{NMR}$ and ${ }^{13} \mathrm{C}-\mathrm{NMR}$ spectra of the reduced product of $\mathrm{CH}_{3} \mathrm{Co}\left(\mathrm{dmgBF}_{2}\right)_{2}$ py (Figure $\mathrm{V}-3$ ) suggest the formation of a new complex of structure 1 .

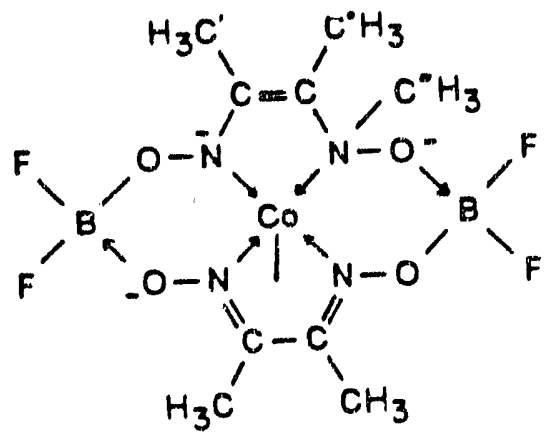

Structure 1

In the $1_{\mathrm{H}-\mathrm{NMR}}$ the broad $1.90 \mathrm{ppm}$ broad peak is assigned to the resonance of $\mathrm{C}^{\prime \prime}{ }^{\prime} \mathrm{H}_{3}$ protons and the $2.01 \mathrm{ppm}$ and $2.04 \mathrm{ppm}$ peaks are assigned to $\mathrm{C}^{\prime \prime} \mathrm{H}_{3}$ and $\mathrm{C}^{\prime} \mathrm{H}_{3}$ groups respectively. A penta-coordination geometry in solution is assumed based on crystal structure of $\mathrm{Co}\left(\mathrm{dmgBF}_{2}\right)_{2} \mathrm{py}^{-} .47$

It is interesting to question why is the unpaired electron not directed to the C-Co antibonding orbital. If the latter happened, an immediate homolysis of the $\mathrm{C}-\mathrm{Co}$ bond and detection of radical selfreaction products would be expected. This question is answered experimentally by an ESR study of the reduction intermediate trapped at liquid $\mathrm{N}_{2}$ temperature.

The one electron reduction product of $R C o\left(d m g B F_{2}\right)_{2} A$ exhibits an unique ESR spectrum (Figure $v-2$ ) with $g_{j !}>g_{\perp}$ which is clearly 
distinguishable from $d^{7}$ inorganic cobalt(II) complexes where $g_{\|}$is most commonly found smaller than $g_{1} \cdot 37,48-50$

According to eq $V-5$ and $V-6,51$

$$
\begin{aligned}
& g_{\|}=g_{e}[1+(4 乙 \Delta \Delta)] \\
& g_{\downarrow}=g_{e}\left[1-\left(4 乙 / \Delta^{\prime}\right)\right]
\end{aligned}
$$

where $\zeta$ is the spin-orbital coupling constant for a single electron and it is always a posttive value, $\zeta=z_{\text {eff }} e^{2}\left\langle r^{-3}\right\rangle /\left(2 m^{2} c^{2}\right)$. Whereas $\Delta$ and $\Delta^{\prime}$ are the absolute values of the energy differences between the ground state and the symmetry allowed lowest excited states.51 Regardless of the numerical details, the odd electron must reside in the $d_{x^{2}}-y^{2}$ orbital instead of in $d_{z} 2$ orbital in order to maintain the relationship of $g_{\|}>g_{1}$. In uther words, the ESR spectrum demands an orbital energy order of $E\left(d_{z} 2\right)>E\left(d_{x^{2}}-y^{2}\right)$. Qualitatively, a strong C-Co bond existing along the $z$-axis in conjunctiun with the upward displacement of cobalt from the equatorial base plane could render the orbital energy of $d_{z} 2$ higher than that of $d_{x^{2}}-y^{2}$. This is because the overlap between $d_{x^{2}}-y^{2}$ orbital of cobalt and o-orbitals of nitrogens may decrease significantly and also because the r-overlap between the $d_{z} 2$ orbital of cobalt and the $p$ orbitals of the equatorial nitrogen atoms becomes no longer negligible once cobalt atom moves above the basal plane as evidenced by a significant $\mathrm{N}-\mathrm{Co}$ bond shortening in $\left.\mathrm{Co}^{\mathrm{I}}(\mathrm{dmgBF})_{2}\right)^{-.4} 4$

It is noticeable that the $g_{\|}$resonances are significantly broadened, which is consistent with the notion that the unpaired electron in $d_{x}{ }^{2}-y^{2}$ 
interacts with the nuclear spin of the four nitrogen atoms of the equatorial ligand.

The residence of the unpaired electron in $d_{x^{2}}-y^{2}$ orbital rather than in the C-Co antibonding orbital, $\mathrm{d}_{z} 2$, explains why the homolysis of the C-Co bond does not occur immediately after the reduction. It also provides a hint as to how the equatorial ligand is directed to participate in the decomposition reactions, Scheme 1. The electron density could move from the $d_{x^{2}}-y^{2}$ orbital of cobalt into the equatorial ligand generating a transient nitrogen centered radical which in turn functions as a radical acceptor to facilitate the cleavage of the $\mathrm{C}$-Co bond, and hence triggers the alkyl group transfer from cobalt to the equatorial. ligand or hydrogen atom migration from alkyl to the nitrogen affording alkenes.

We summarize the reduction induced decomposition reactions of $\mathrm{RCo}(\mathrm{dmgBF} 2)_{2} \mathrm{~A}$ in to Scheme 2 .

\section{Scheme 2}

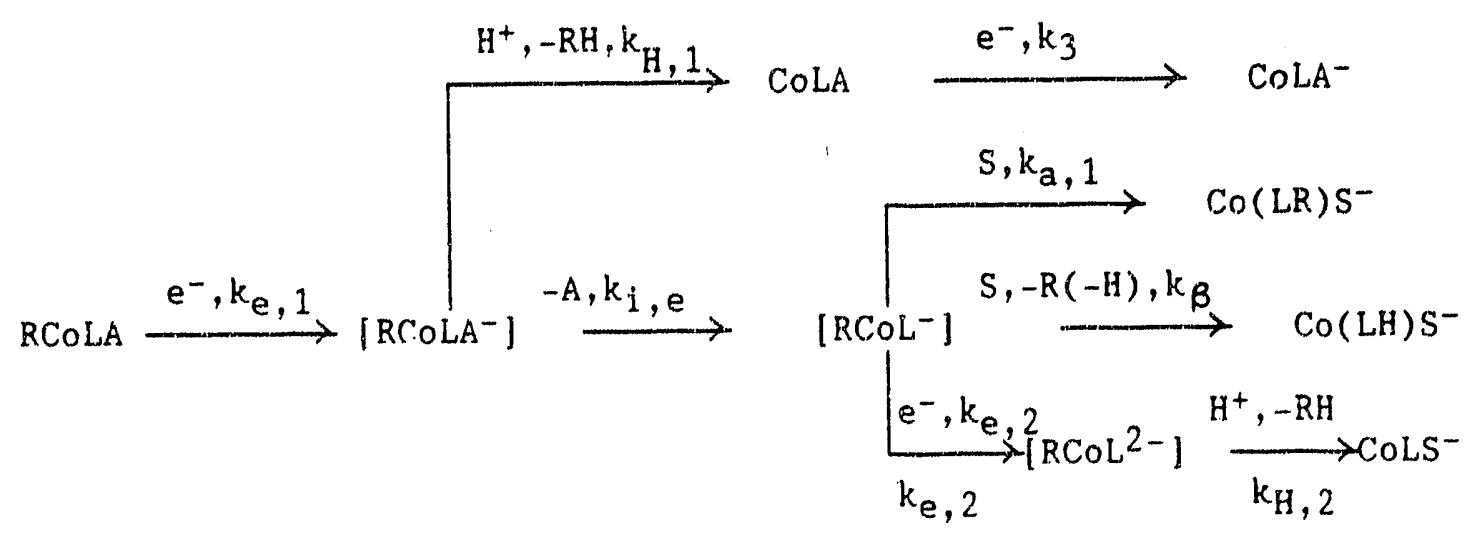


Rinetics. The reduction of primary alkyl cobalt(III) macrocyclic complexes, $\mathrm{RCo}\left(\mathrm{dmgBF}_{2}\right)_{2} \mathrm{~A}$, by $\mathrm{Ni}(\mathrm{tmc})^{+}$obeys monophasic pseudo-first order rate law, eq $\mathrm{V}-1$. The first order dependence on $\left[\mathrm{Ni}(\mathrm{tmc})^{+}\right]$in conjunction with the lack of $\left[\mathrm{Ni}(\mathrm{tmc})^{2+}\right]$ effect (over $10^{-4}$ to $10^{-3} \mathrm{M}$ ) on $k_{\text {obs }}$ values as well as $\mathrm{pH}$ independence between $\mathrm{pH} 11-12$ ruled out the possibilities for $k_{H, 1}, k_{e, 2}, k_{i, e}$ or $k_{\beta}$ steps to be rate limiting. Also the reduction of $\mathrm{Co}\left(\mathrm{dmgBF}_{2}\right)_{2}(\mathrm{py})_{2}$ to $\mathrm{Co}\left(\mathrm{dmgBF}_{2}\right)_{2} \mathrm{py}^{-}$proceeds very fast (> $\left.10^{6} \mathrm{M}^{-1}, \mathrm{~s}^{-1}\right)$, therefore the rate determine step is the initial electron transfer of eq $V-7$.

$$
\mathrm{RCo}(\operatorname{dmgBF} 2)_{2} \mathrm{~A}+\mathrm{Ni}(\mathrm{tmc})^{+} \rightarrow \mathrm{RCo}\left(\mathrm{dmgBF}_{2}\right)_{2} \mathrm{~A}^{-}+\mathrm{Ni}(\mathrm{tmc})^{2+}
$$

Reduction of aralkylcobalt(II) macrocyelic complexes, $\mathrm{ArCH}_{2} \mathrm{Co}(\mathrm{dmgBF})_{2} \mathrm{~A}$, by $\mathrm{Ni}(t m \mathrm{c})^{+}$proceeded in a biphasic fashion, signaling an accumulation of reduction intermediate, $\mathrm{ArCH}_{2} \mathrm{Co}\left(\mathrm{dmgBF}_{2}\right)_{2}{ }^{-}$. The second order rate constants deduced from the fast phase are close to those obtained for alkylcobalt(III) analogues, and assigned to $k_{e}, 1$ step. An electron withdrawing substituent in the aralkyl group causes an increase of the reduction rate whereas an electron donating substituent causes a decrease in the reluction rate. We assign the second order rate constant of the slow phase to $k_{e, 2}$ step for the following reasons. (1) The pseudo-first-order rate constant, kobs, shows a first order dependence on $\left[\mathrm{Ni}(\mathrm{tmc})^{+}\right]$and yet is independent of $\left[\mathrm{Ni}(\mathrm{tmc})^{2+}\right]$. (2) optical absorbance changes of the two phases add up to the total absorbance change expected for a $100 \%$ conversion of aralkylcobalt(III) macrocycles to inorganic 
cobalt(I) macrocycles. (3) Biphasic kinetic profiles were observed only for aralkylcobalt complexes.

It is interesting to note that the biphasic behavior is not observed in the reduction of primary alkylcobalt(III) macrocycles by $\mathrm{Ni}(\mathrm{tmc})^{+}$. In another word, $k_{e}, 2^{-k_{H}, 2}$ sequence of reaction does not contribute much there. This phenomenon can be explained by the structural and electronic difference between primary-alkylcobalt(III) complexes and their aralkyl analogues. The decomposition reactions probably operate much better in the alkyl series than in the aralkyl series. With much better electron delocalization ability of aralkyl group, the $\alpha$-carbon in the aralkylcobalt complexes should be much less carbanion in character as compared to that of alkylcobalt analogues, hence much less subject to hydrolysis $\left(k_{H}, 1\right)$. This renders the relative importance of $k_{i, a}$ pathway higher in aralkylcobalt series over that in alkyl cobalt series. Yet. the lack of $\beta$-hydrogen shuts off the $k_{\beta}$ pathway. Therefore the reaction is forced to proceed along $k_{e, 2}$ pathway. Obviously, the $k_{H, 2}$ step also helps to pull the second electron transfer step $k_{e, 2}$ to completion. Apparently there is no need for the reduction of alkylcobalt complexes by $\mathrm{Ni}(\mathrm{tmc})^{+}$to proceed along the $k_{e, 2}$ pathway. In the alkylcobalt series, both hydrolysis $\left(k_{H, 1}\right)$ and $\beta$-hydrogen elimination $\left(k_{\beta}\right)$ operate in a facile manner, and thus no intermediate accumulatinn is observed.

Generally speaking, $k_{e, 1}$ values for aralkylcobalt macrocyclic complexes are higher than those for their alkyl analogues, consistent with the differences among their first electron reduction potentials 21 and the notion that aralkyl groups stablize reduced cobalt better by electron delncalization than alkyl groups do. The higher $k_{e, 1}$ values of 
aralkylcobalt complexes are probably also partly responsible for the observed accumulation of the reduction intermediate. 


\section{CONCLUSIONS}

Our observations about reductions and subsequent decompositions of various $\mathrm{RCO}^{\mathrm{III}}(\mathrm{dmgBF})_{2} \mathrm{~A}^{\mathrm{n}}$ - are accommodated in Scheme 2. (1) The first electron reduction of $\mathrm{RCo} I I I\left(d m g B F_{2}\right){ }_{2}$ py generates a $d^{7}$ cobalt species with $(t)^{6}\left(d_{x^{2}}-y^{2}\right)^{1}$ electron configuration. The existence of a $C$-Co bond in this $d^{7}$ cobalt species is strongly suggested by the observed ESR spectrum. (2) Two reactions may occur after the first electron reduction. They are hydrolysis and intramolecular electron transfer. The later reaction further branches into three follow-up reactions, $\beta-B$ elimination, alkyl group migration, and the second electron reduction. The hydrolysis and $\beta-H$ elimination produce alkanes and alkenes respectively. (3) The relative importance of hydrolysis over $\beta-H$ elimination is influenced by water content of the solvent, and controlled by the probability of the intramolecular electron transfer (from cobalt(I) to a $\pi^{*}$-orbital of the equatorial ligand) and by the availability of $\beta$-hydrogen. (4) The first electron reduction by $\mathrm{Ni}(\mathrm{tmc})^{+}$ occurs at high speeds $\left(6 \times 10^{4}-10^{6} \mathrm{M}^{-1} \mathrm{~S}^{-1}\right)$, whereas the second electron reduction proceeds more slowly $\left(10^{4} \mathrm{M}^{-1} \mathrm{~S}^{-1}\right)$. (5) The life times of the first electron reduction products, as reflected by their kinetic behaviors (monophasic vs, hiphasic), are determined by both the electron delocalization ability of the axial organic groups and the availability of $\beta$-hydrogen. 
Table V-1. Distribution of the Decomposition Products, RH/R(-H) Formed by Reduction of $\mathrm{RCo}(\mathrm{dmgBF})_{2}$ py in $\mathrm{CH}_{3} \mathrm{CN} / \mathrm{H}_{2} \mathrm{O}$ Solutions ${ }^{\mathrm{a}}$

\begin{tabular}{|c|c|c|}
\hline \multirow{2}{*}{ Complex } & \multicolumn{2}{|c|}{$\mathrm{RH} / \mathrm{R}(-\mathrm{H})$} \\
\hline & $0 \% \mathrm{H}_{2} \mathrm{O}$ & $33 \% \mathrm{H}_{2} \mathrm{O}$ \\
\hline $\left.\mathrm{CH}_{3} \mathrm{Co}(\mathrm{dmgBF})_{2}\right)_{2} \mathrm{py}$ & $1.0 / 0.0$ & $1.0 / 0.0$ \\
\hline $\left.\mathrm{C}_{6} \mathrm{H}_{5} \mathrm{CH}_{2} \mathrm{Co}(\mathrm{dmgBF})_{2}\right)_{2} \mathrm{py}$ & $1.0 / 0.0$ & $1.0 / 0.0$ \\
\hline $\left.\mathrm{C}_{2} \mathrm{H}_{5} \mathrm{Co}(\mathrm{dmgBF})_{2}\right)_{2} \mathrm{py}$ & $0.38 / 0.62$ & $0.55 / 0.45$ \\
\hline $\left.1-\mathrm{C}_{3} \mathrm{H}-\mathrm{Co}(\mathrm{dmgBF})_{2}\right)_{2}$ & $0.22 / 0.78$ & $0.68 / 0.32$ \\
\hline
\end{tabular}

a Reduction was conducted at $-1.0 \mathrm{~V}$ (vs. $\mathrm{Ag} / \mathrm{AgCl}$ ) with $0.06 \mathrm{M} \mathrm{Me}_{4} \mathrm{NBF}_{4}$ as supporting electrolyte, at $25^{\circ} \mathrm{C} .\left[\mathrm{RCo}\left(\mathrm{dmgBF}_{2}\right)_{2} \mathrm{py}\right]=2.0 \times 10^{-3} \mathrm{M}$. 
Table V-2. Second Order Rate Constants for Reductions of RCo(dmgBF $)_{2} \mathrm{~A}$ by $\mathrm{N} 1(\mathrm{tmc})^{+}$in Aqueous Solution ${ }^{\mathrm{a}}$

\begin{tabular}{|c|c|c|}
\hline Complex & $k_{e, 1} / M^{-1} s^{-1}$ & $k_{e, 2} / M^{-1} s^{-1}$ \\
\hline $\left.\mathrm{CH}_{3} \mathrm{Co}(\mathrm{dmgBF})_{2}\right)_{2} \mathrm{py}$ & $5.95 \times 10^{4}$ & \\
\hline $\left.\mathrm{C}_{2} \mathrm{H}_{5} \mathrm{Co}(\mathrm{dmgBF})_{2}\right)_{2} \mathrm{py}$ & $1.28 \times 10^{5}$ & \\
\hline $1-\mathrm{C}_{3} \mathrm{H}_{7} \mathrm{Co}\left(\mathrm{dmgBF}_{2}\right)_{2} \mathrm{py}$ & $1.57 \times 10^{5}$ & \\
\hline $1-\mathrm{C}_{3} \mathrm{H}_{7} \mathrm{Co}(\mathrm{dmgBF})_{2} \mathrm{OH}^{-}$ & $1.14 \times 10^{5}$ & \\
\hline $\left.4-\mathrm{CH}_{3} \mathrm{C}_{6} \mathrm{H}_{4} \mathrm{CH}_{2} \mathrm{Co}(\mathrm{dmgBF})_{2}\right)_{2} \mathrm{py}$ & $7.78 \times 10^{5}$ & $3.06 \times 10^{4}$ \\
\hline $\left.\mathrm{C}_{6} \mathrm{H}_{5} \mathrm{CH}_{2} \mathrm{Co}(\mathrm{dmgBF})_{2}\right)_{2} \mathrm{py}$ & $8.00 \times 10^{5}$ & $1.70 \times 10^{4}$ \\
\hline $4-\mathrm{BrC}_{6} \mathrm{H}_{4} \mathrm{CH}_{2} \mathrm{Co}\left(\mathrm{dmgBF}_{2}\right)_{2} \mathrm{py}$ & $1.14 \times 10^{6}$ & $2.91 \times 10^{4}$ \\
\hline $4-\mathrm{BrC}_{6} \mathrm{H}_{5} \mathrm{CH}_{2} \mathrm{Co}(\mathrm{dmgBF} 2)_{2} \mathrm{OH}^{--}$ & $1.75 \times 10^{6}$ & $2.70 \times 10^{4}$ \\
\hline
\end{tabular}

$a_{\text {At }} 25^{\circ} \mathrm{C}$ with $[\mathrm{NaOH}]=0.02 \mathrm{M}$, ionic strength $\mu=0.10 \mathrm{M}$. 


\section{$\operatorname{sigh}$}

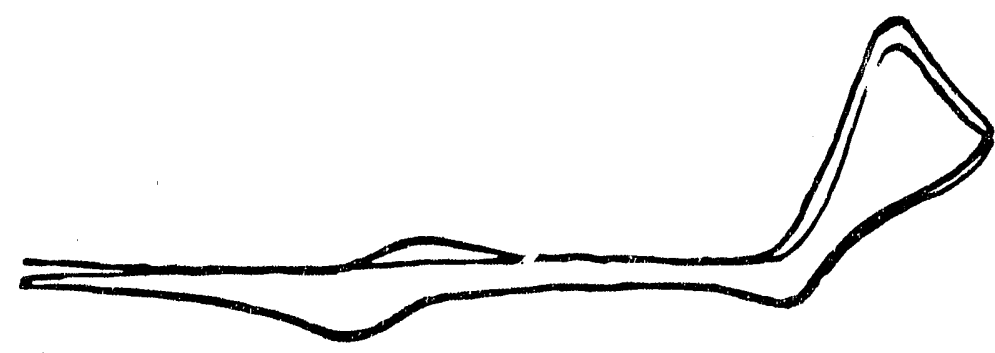

I
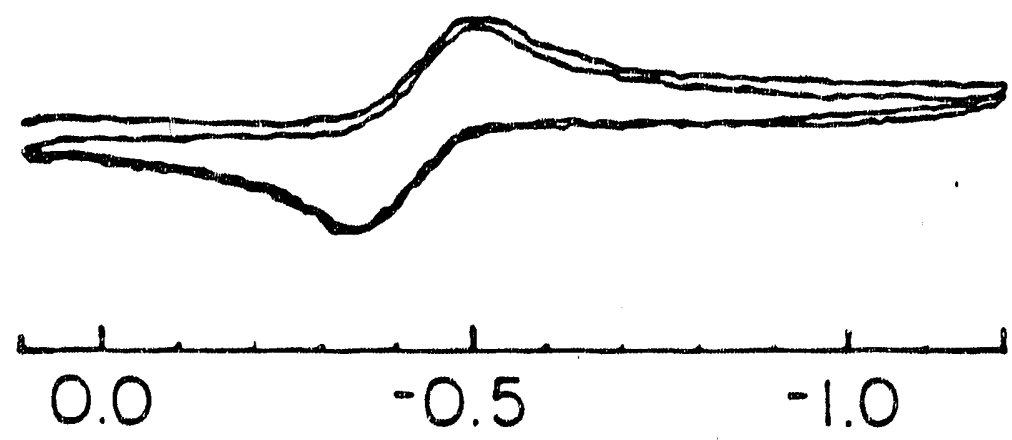

Ela.T)

Pigure V-1. Cyclic voltammograms at $25^{\circ} \mathrm{C}$ in air-free $0.06 \mathrm{M} \mathrm{Me}_{4} \mathrm{NBF}_{4}$ $\mathrm{CH}_{3} \mathrm{CN}$ solutions of (a) $\left.2.0 \times 10^{-3} \mathrm{M} \mathrm{I}_{1}-\mathrm{C}_{3} \mathrm{H}_{7} \mathrm{Co}_{3} \mathrm{Co}(\mathrm{dmgBF})_{2}\right)_{2} \mathrm{H}_{2} \mathrm{O}$, scan rate $1.2 \mathrm{~V} / \mathrm{s}$; (b) $2.0 \times 10^{-3} \mathrm{M} \mathrm{Co}\left(\mathrm{dmgBF}_{2}\right)_{2}\left(\mathrm{H}_{2} \mathrm{O}\right)_{2}$, scan rate $1.3 \mathrm{~V} / \mathrm{s}$ 

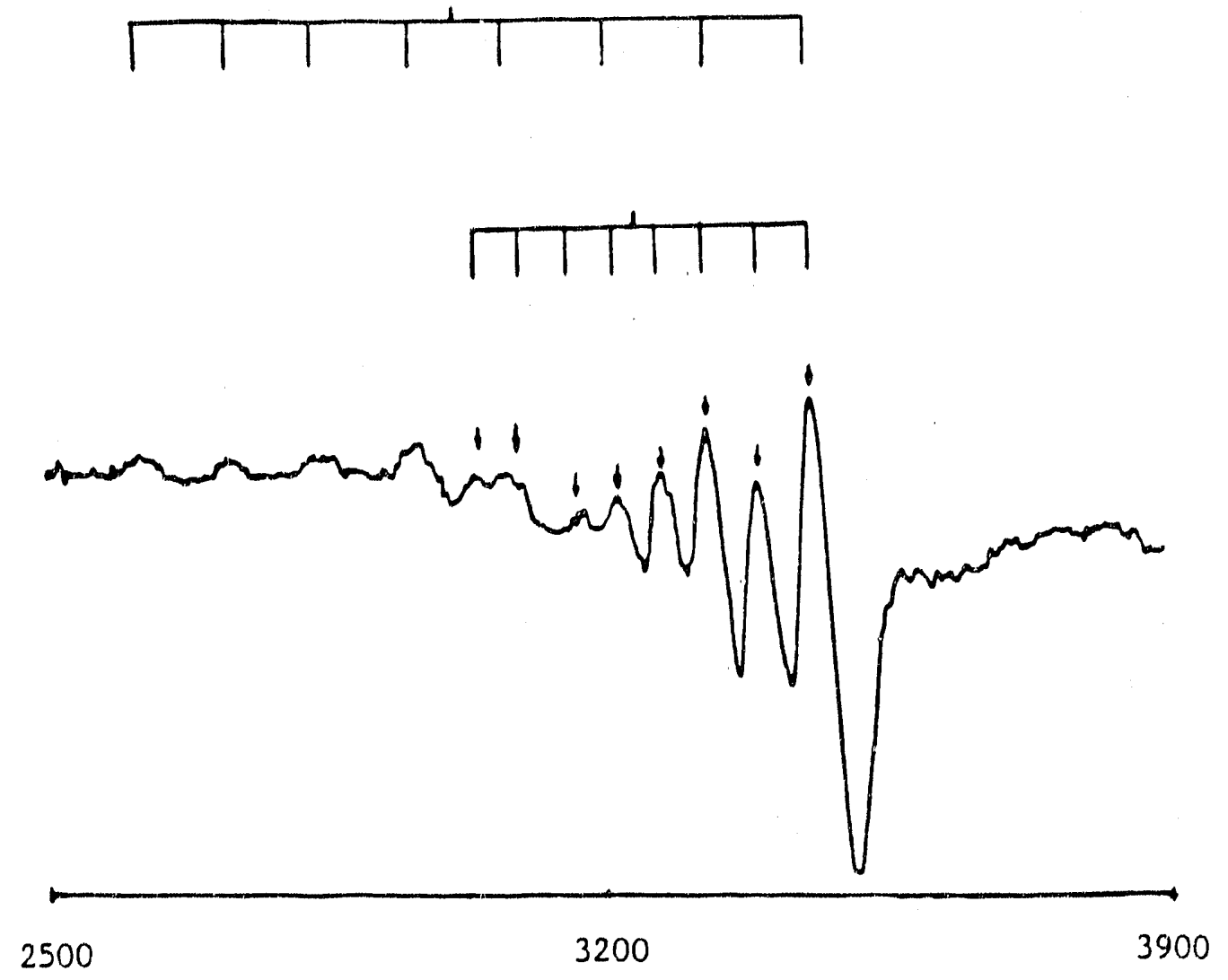

Figure V-2. ESR spectrum of a frozen sollition ( $1 \cap n \mathrm{~K}$ ) obtained after a $2.0 \times 10^{-3} \mathrm{M}$ solution of $4-\mathrm{BrC}_{6} \mathrm{H}_{4} \mathrm{CH}_{2} \mathrm{Co}\left(\mathrm{dmgBF}_{2}\right)_{2}\left(\mathrm{H}_{2} \mathrm{O}\right)$ was partly reduced electrochernically at $-1.0 \mathrm{~V}$ in $0.06 \mathrm{M} \mathrm{Me}_{4} \mathrm{NBF}_{4}$ in acetonitrile. $V=9.4582 \mathrm{GH} z, \mathrm{CF}=3200 \mathrm{G}, \mathrm{SW}=1400 \mathrm{G}, \mathrm{PW}$ $=12 \mathrm{~dB}$, Gain $=1.25 \times 10^{6}$, Mod $=4.0 \mathrm{Gpp}, \mathrm{ST}=500 \mathrm{~s}, \mathrm{TC}=$ $2.0 \times 10^{3} \mathrm{~ms}$ 

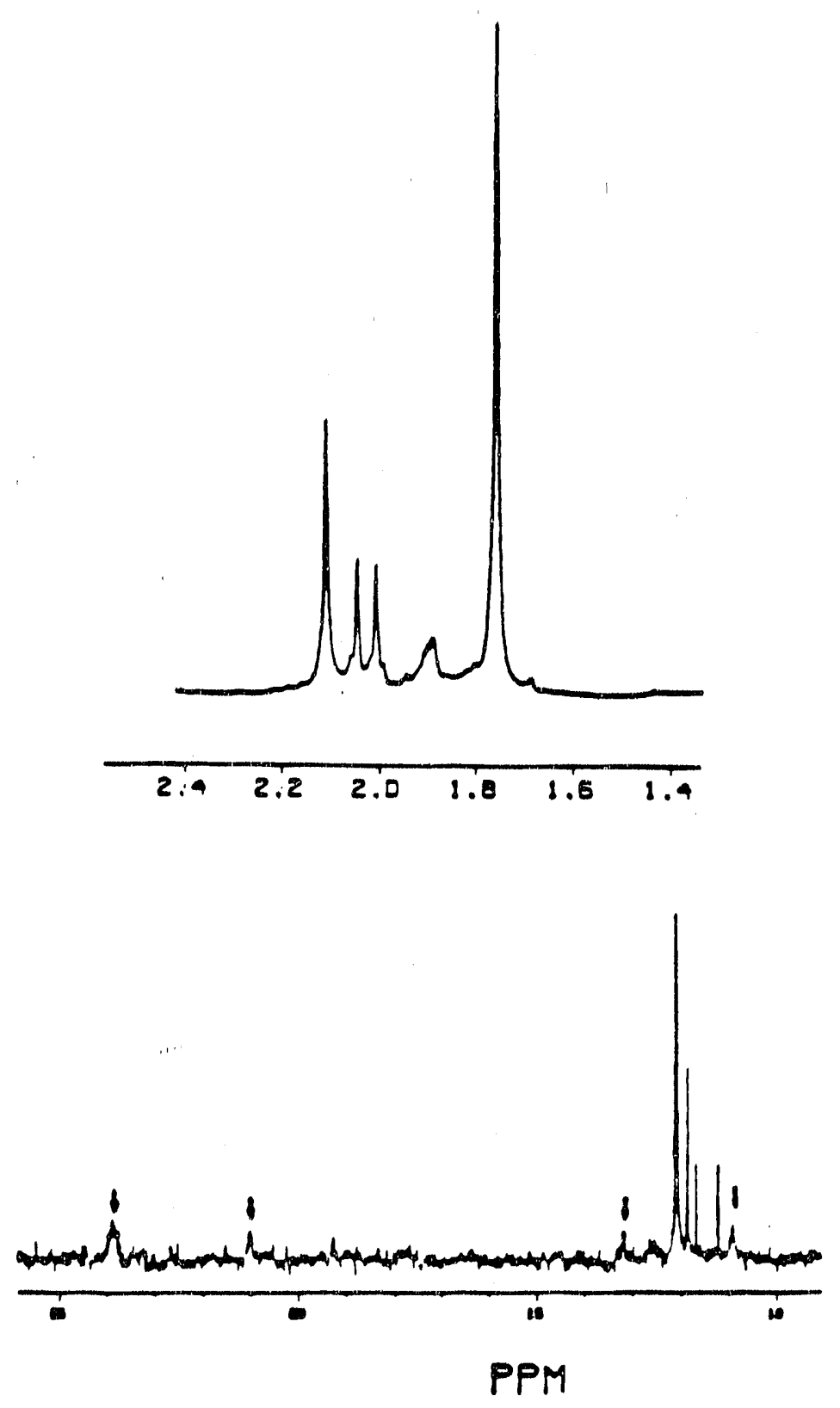

Figure V-3. ${ }^{1}$ H-NMR (a), and ${ }^{13} \mathrm{C}-\mathrm{NMR}$ (b) of $1.0 \times 10^{-2} \mathrm{M} \mathrm{CH}_{3} \mathrm{Co}\left(\mathrm{dmgBF}_{2}\right)_{2}$ py reduced by excess $\mathrm{NaBH}_{4}$ "in air-free $\mathrm{DMSO}^{-\mathrm{d}_{6}}$ solution at 25 ${ }^{\circ} \mathrm{C}$. Arrows in (b) show four kinds of different carbons attached to nitrogens 


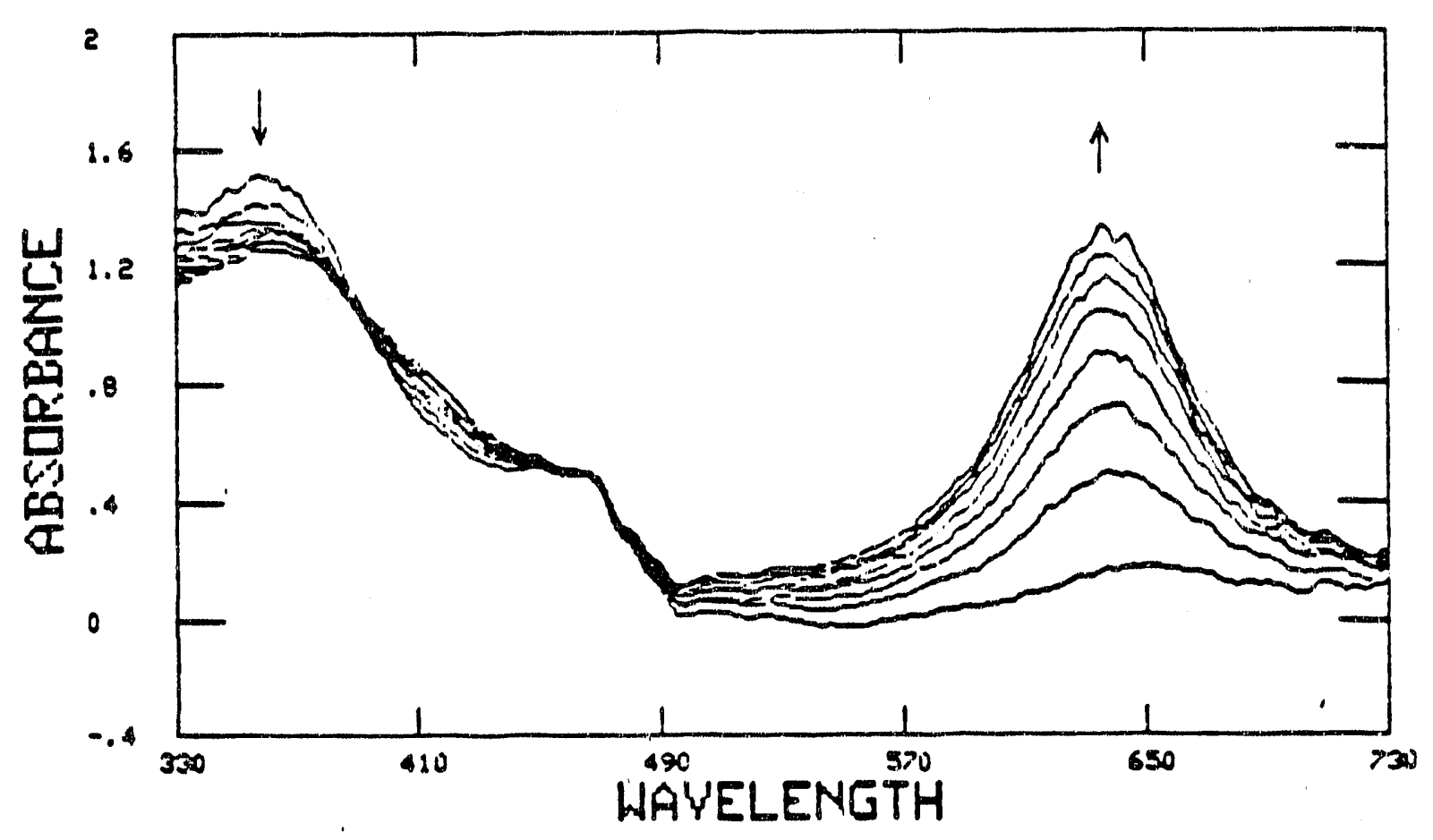

Figure V-4. Fast repetitive scans at $25^{\circ} \mathrm{C}$, following the reaction between $1.7 \times 10^{-4} \mathrm{M} \mathrm{CH}_{3} \mathrm{Co}\left(\mathrm{dmgBF}_{2}\right)_{2}$ py and $4.1 \times 10^{-4} \mathrm{M}$ $\mathrm{Ni}(\mathrm{tmc})^{+}$in $1: 1 \mathrm{CH}_{3} \mathrm{COCH}_{3} / \mathrm{H}_{2} \mathrm{O}$ air-free solution. Ionic strength $\mu=0.06 \mathrm{M}\left(\mathrm{LiClO}_{4}\right) ; \mathrm{pH}=12(\mathrm{NaOH})$ 


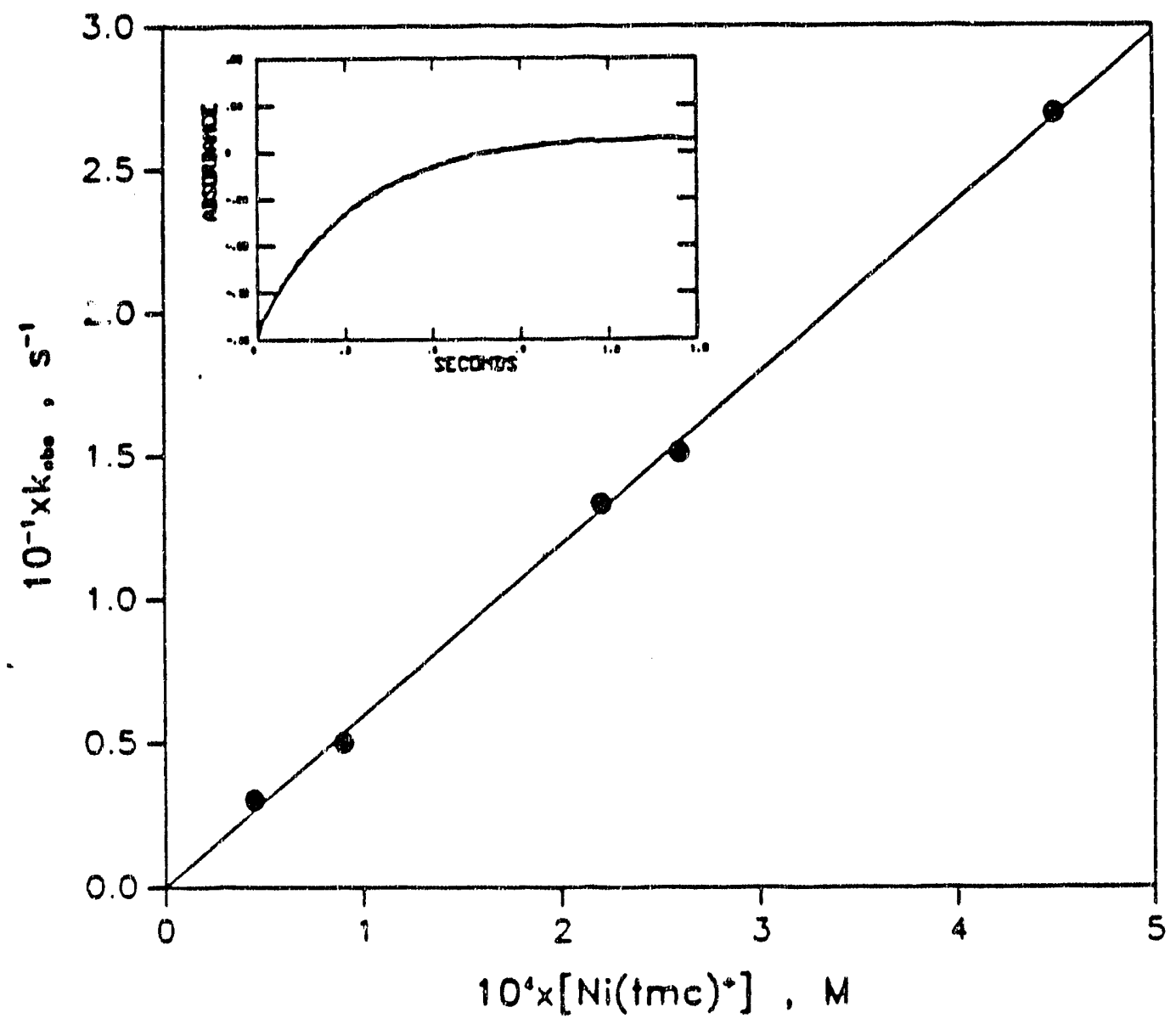

Pigure V-5. A plot showing the variation of the pseudo-first-order rate constant kobs with concentration of $\mathrm{Ni}(\mathrm{tmc})+$ at $25{ }^{\circ} \mathrm{C}$ for the reaction between $\mathrm{CH}_{3} \mathrm{Co}\left(\mathrm{Amg} \mathrm{BF}_{2}\right)_{2} \mathrm{PY}$ and $\mathrm{Ni}(\mathrm{rmc})^{+}$in an air-free aqueous solution of $\mathrm{pH} 12$ ( $\mathrm{NaOH}$ ) and $0.10 \mathrm{M}$ ionic strength $\left(\mathrm{LiClO}_{4}\right)$. The inset shows a stopped-flow kinetic trace monitored at $610 \mathrm{~nm}$ for a run with $[\mathrm{Ni}(\mathrm{tmc})+]_{\mathrm{av}}=2.7 \times 10^{-4}$ $\mathrm{M}$ and $\left[\mathrm{CH}_{3} \mathrm{Co}(\mathrm{dmgBF} 2)_{2} \mathrm{py}\right]_{0}=3.7 \times 10^{-5} \mathrm{M}$ 


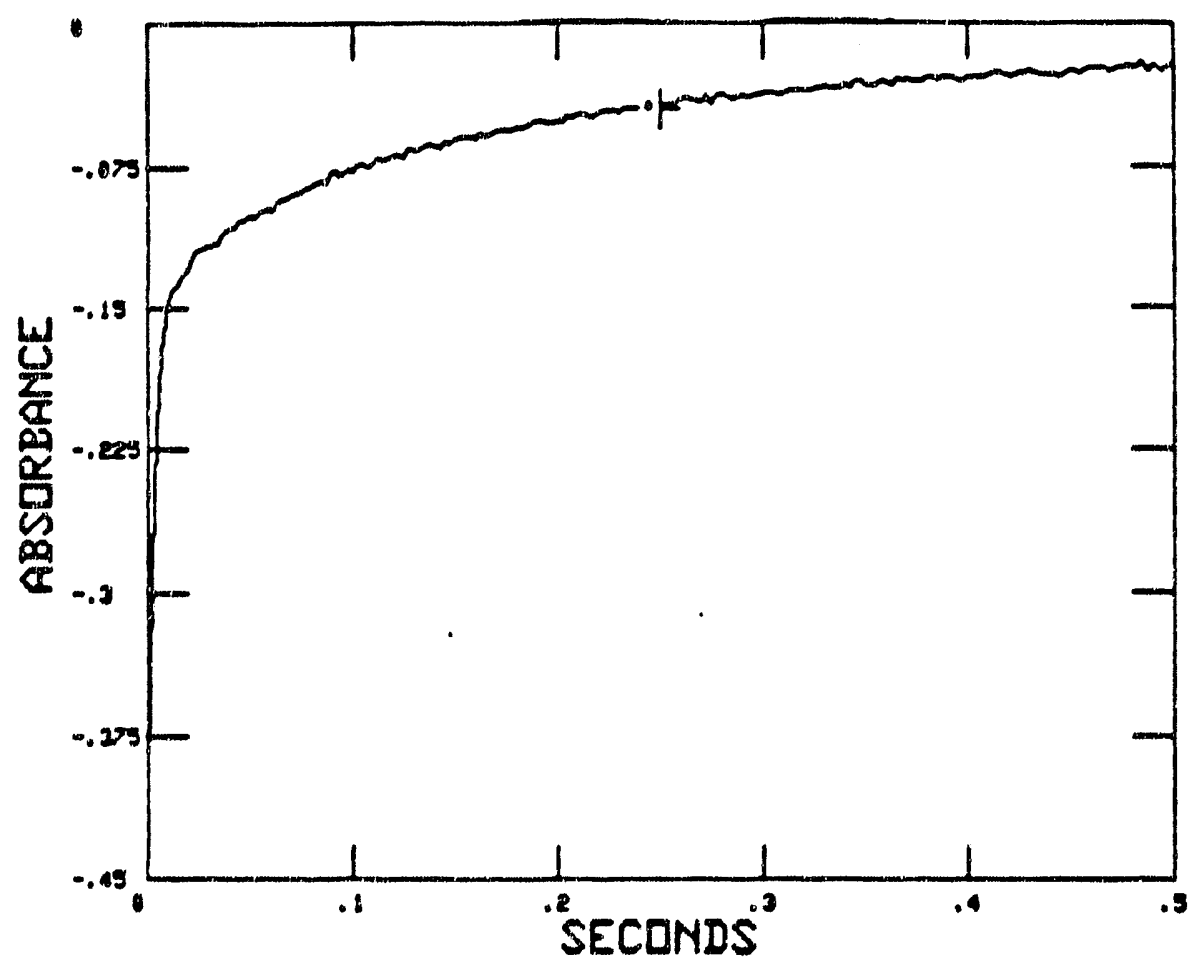

Pigure V-6. A typical bi-exponential kinetic trace recorded at $25^{\circ} \mathrm{C}$ in an air-free aqueous solution of $\mathrm{pH} 12$ (NaOH) and $0.10 \mathrm{M}$ ionic strength $\left(\mathrm{LiCl}_{/ 4}\right)$, showing a vo-step reaction process. The reaction was monitored at $610 \mathrm{~nm}$ with $\left[4-\mathrm{BrC}_{6} \mathrm{H}_{4} \mathrm{CH}_{2} \mathrm{CO}(\mathrm{dmgBF} 2)_{2}\left(\mathrm{H}_{2} \mathrm{O}\right)\right]_{0}=2.5 \times 10^{-5} \mathrm{M}$, and $\left[\mathrm{Ni}(\mathrm{tmc})^{+}\right]_{0}=2.64 \times 10^{-4} \mathrm{M}$ 


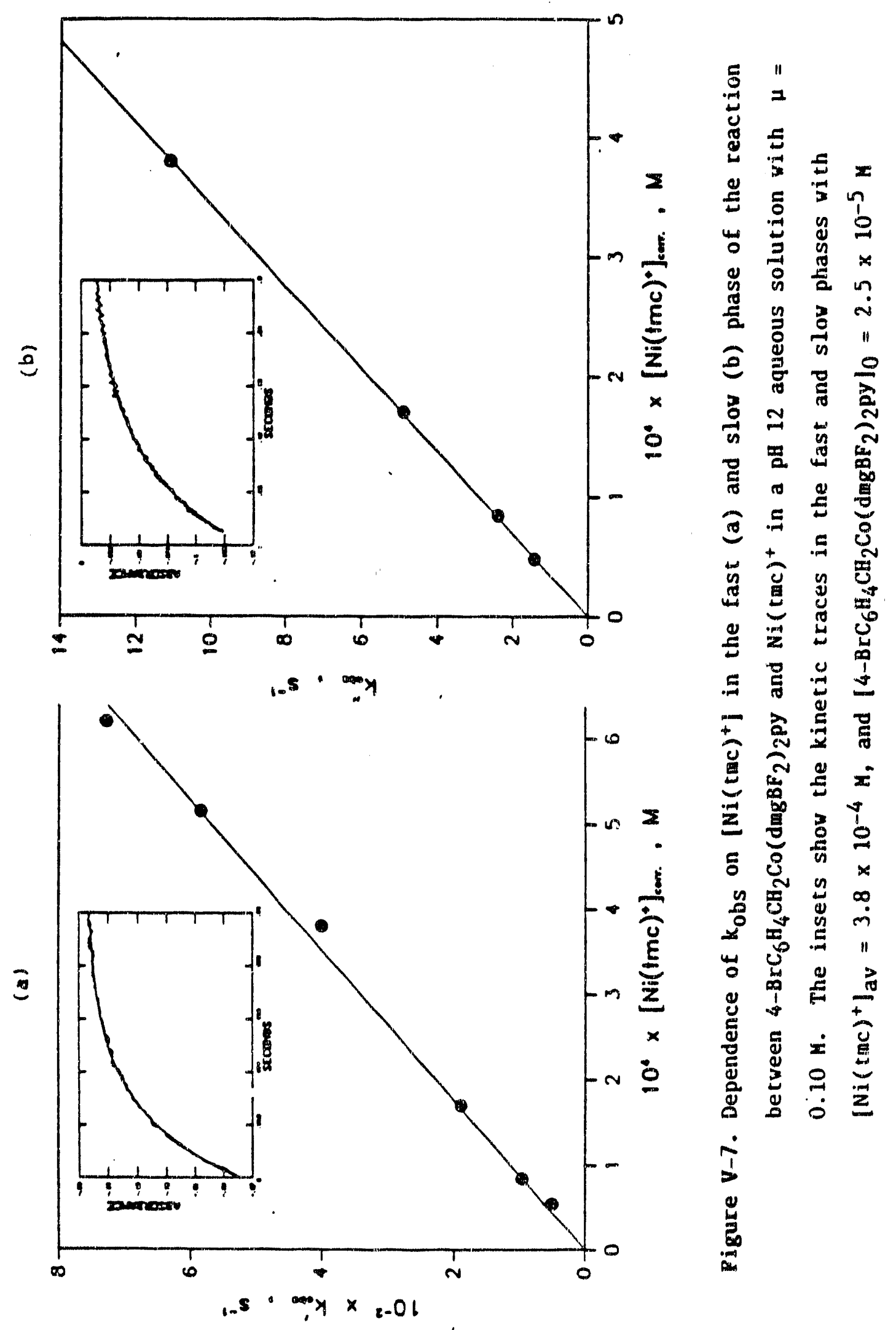




\section{REFERENCES}

(1) Iodice, A. A.; Barker, H. J. Biol. Chem. 1963, 238, 2094.

(2) Eagar, R. G.; Baltimore, B. G.; Herbst, M. M.; Barker, H.A.; Richards, J. H. Biochemistry 1972, 11, 253.

(3) Blakley, R. L. J. Biol. Chem. 1965, 240, 2173.

(4) Goulian, M.; Beck, W. S. J. Biol. Chem. 1966, 241, 4233.

(5) Beck, W. S. Vitam. Horm. 1968, 26, 413.

(6) Blakley, R. L. "The Biochemistry of Folic Acid and Related Pteridines" Wiley, New York, 1969, Chapter 9.

(7) Weissbach, H.; Tayler, R. T. Vitam. Horm. 1968, 26, 395.

(8) Lezius, A. G.; Barker, H. A. Biochemistry 1965, 4, 510.

(9) Stadtman, T. C.; Blaylock, B. A. Fed. Proc. 1966, 25, 1657.

(10) Ljungdahl, L.; Irion, E.; Wood, H. G. Fed. Proc. 1966, 25, 1642.

(11) Wood, J. M.; Wolfe, R. S.; Biochemistry 1966, 5, 3598.

(12) Lentz, K.; Wood, H.G. J. Biol. Chem. 1955, 215, 645.

(13) Ljungdahl, L.; Irion, E.; Wood, H. G. Biochemistry 1965, 4, 2771.

(14) Schrauzer, G. N.; Sibert, J. W. J. Am. Chem. Soc. 1970, 92, 3509.

(15) Martin, B. D.; Finke, R. G. J. Am. Chem. Soc. 1990, 12, 2419.

(16) Costa, G.; Puxeddu, A.; Reisenhofer, E. Bioelectrochem. Bioenerg. $1974,1,29$.

(17) Costa, G.; Puxeddu, A.; Reisenhofer, E. Experientia Suppl. 1971, 18,235 .

(18) Costa, G.; Puxeddu, A.; Reisenhofer, E. J. Chem. Soc. Commun. $1971,993$. 
(19) Brockway, D. J.; West, B. 0.; Bond, A. M. J. Chem. Soc., Dalton Trans. 1979, 1891 .

(20) Costa, G.; Puxeddu, A.; Rersenhofer, E. J. Chem. Soc., Dalton Trans. 1972, 1519.

(21) Costa, G.; Puxeddu, A.; Tavagnacco, C.; Balducci, G.; Kumar, R. Gazerta Chim. Ital. 1986, 116, 735.

(22) Dolfhin, D.; Johnson, A. W.; Rodrigo, R. Ann. N.Y. Acad. Sci. $1964,112,590$.

(23) Schrauzer, G. N.; Acc. Chem. Res. 1968, 1, 97.

(24) (a)Schrauzer, G. N.; Pure Appl. Chem. 1973, 33, 545. (b) Schrauzer, G. N.; Grate, J.H.; Katz, R. H. Bioinorg. Chem. 1978, 8, 1. (c) Schrauzer, G. N.: Deutsch, E.; Windgassen, R. J. J. Amer. Chem. Soc. 1968, 90, 2441.

(25) Schrauzer, G. N.; Sock, I. A.; Holland, R. J.; Beckham, T. M.; Rubin, E. M.; Sibert, J. W. Bioinorg. Chem. 1.972, 2, 93.

(26) Schrauzer, G.N.; Sibert, J.H. J.Am. Chem. Soc. 1970, 92, 3509.

(27) Atkins, M. P.; Golding, B. T.; Burg, A.; Johnson, M. D.; Sellars, P. J. J.Am. Chem. Soc. 1980, 102, 3630.

(28) Lelloang, M.; Robin, Y.; Devynck, J.; Bied-Charreton, C.; Gaudemer, A.; J. Organomet. Chem. 1981, 222, 311 .

(29) Rytz, G.; Halder, L.; Scheffoìd, R. In "yitamin B12: Proceenings of the Third European Symposium". Zagalak, B.; Friedrich, H. Eds., Walter de Gruyter, New York, 1979, p 173.

(30) Walder, L.; Rytz, G.; Meier, K.; Scheffold, R. Helv. Chim. Acta $1978,61,3013$. 
(31) Schrauzer, G. N.; Windgassen, R.J. J. Am. Chem. Soc. 1966, 88, 3738 .

(32) Bakac, A.; Espenson, J. H. J. Am. Chem. Soc. 1984, 106, 5197.

(33) Tovrog, B. S.; Kitko, D. J.; Drago, R. S. J. Ain. Chem. Soc. 1976, $\underline{98}, 5144$.

(34) Barefield, E. K.; Wagner, F. Inorg. Chem. 1973, 12, 2435.

(35) Ram, M. S.; Bakac, A.; Espenson, J. H. Inorg. Chem. 1986, 25, 3267.

(36) Heller, S. R. "EPA/NIH Mass Spectral Data Base" Vol. 1, Vashington, 1978.

(37) Bakac, A.; Brynildson, M. E.; Espenson, J. H. Inorg. Chem. 1986, 25, 4108 .

(38) The configuration of the singly reduced organochromium(II) species is assumed to be penta coordinated because of its expected ligand substitutional lability ( $17 \mathrm{e}^{-}, \mathrm{Co}$ (II) species). Experimentally, the distribution of the decomposition products shows no observable difference wether one started with $\mathrm{RCo}\left(\mathrm{dmgBF}_{2}\right)_{2} \mathrm{py}$ or with $\left.\mathrm{RCo}(\mathrm{dmgBF})_{2}\right)_{2} \mathrm{H}_{2} \mathrm{O}$.

(39) "Lange's Handbook of Chemistry" 13 th Ed. Edt. by Dean, J.A., McGraw-Hill Book Company, New York, 1985.

(40) Brown, K. L.; Syeverenyi, Z. Inorg. Chem. Acta 1986. 119, 149.

(41) Brown, K. L.; Hessley, R. K. Inorg. Chem. 1980, 19, 2410.

(42) Espenson, J. H.; Wang, D. M. Inorg. Chem. 1979, 18, 2853.

(43) Samse 1, E. G.; Kochi, J. K. J. Am. Chem. Soc. 1986, 108, 4790.

(4k) Tamblyn, W. H.; Klingler, R. J.; Hwang, W. S.; Kochi, J. K. J. Am. Chem. Soc. 1981, 103, 3161 . 
(45) Sorek, Y.; Cohen, H.; Meyerstein, D. J. Chem. Soc. Faraday Trans. $\underline{1}, 1989, \underline{85}, 1169$.

(46) Brown, K. L. J. Am. Chem. Soc. 1979, 101, 6600.

(47) Shi, S.; Daniels, L.M.; Espenson, J. H. Inorg. Chem. (submitted).

(48) Endicott, J. F.; Lilie, J.; Kuszaj, J. M.; Ramaswamy, B. S.;

Schmonsees, W. G.; Simic, M. S.; Glick, M. D.; Rillema, J.A. J. Am. Chem. Soc. 1977, 99, $42 \%$.

(49) Walker, F. A. J. Am. Chem. Soc. 1970, 92, 4235.

(50) Nishida, Y.; Kida, S.; Coord. Chem. Rev. 1979, 27, 275.

(51) Lin, W. C.; McDowell, C. A.; Ward, D.J. J. Chem. Phys. 1968, 49, 2883. 
PART VI. MOLECULAR STRUCTURE OF A COBALT(I) COMPLEX LACRING A CARBONYL LIGAND. A UNTQUE EXAMPLE OP CO-N BOND SHORTENING 


\section{INTRODUCTION}

It is well known that Vitamin $B_{12}$ (= cyanocobalamin) and its derivative $B_{12 a}$ (aquocobalamir) can be reduced by one electron to $B_{12 r}$ (= cobalt(II)cobalamin) and by two electrons to $B_{12 s} \cdot{ }^{1}$ The crystal structure of $B_{12} r$ was also determined recently. ${ }^{2}$ Vitamin $B_{12 s}$ exists in solution as the cobalt(I) complex, although at higher acidities it is in

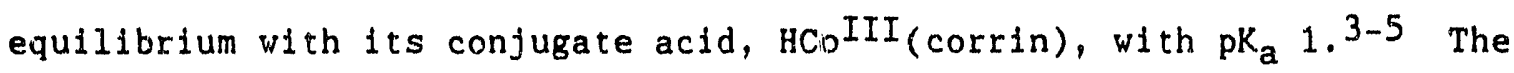
$\mathrm{B}_{12}$ model complexes $\mathrm{Co}^{\mathrm{I}}(\mathrm{dmgH})_{2} \mathrm{py}^{-}$and $\left.\mathrm{HCo} \mathrm{CII}_{(\mathrm{dmgH}}\right)_{2} \mathrm{py}$ are also known; here the acidity is lower $\left(\mathrm{pk}_{\mathrm{a}} 9\right)^{6-9}$ and the rate of acld-base interconversion sufficiently low that the two forms undergo separate and not always identical chemical reactions. 9-12

We have now succeeded in isolating single crystals of a closely related model complex which is an example of a nonporphyrin cobalt(I) macrocycle, and which lacks a carbonyl or phosphine ligand. The compound studied is $\left[\left(\mathrm{CH}_{3}\right)_{4} \mathrm{~N}\right]\left[\mathrm{Co}\left(\mathrm{dmgBF}_{2}\right)_{2} \mathrm{py}\right] \mathrm{CH}_{3} \mathrm{CN}$. It contains the anion $\left.\mathrm{Co}(\mathrm{dmgBF})_{2}\right)_{2} \mathrm{py}^{-}\left(\mathrm{py}=\mathrm{C}_{5} \mathrm{H}_{5} \mathrm{~N} ;(\mathrm{dmgBF})_{2}\right)^{2-}=$ bis[(difluoroboryl)dimethylglyoximato]), which was first prepared by Schrauzer. 13 This is of interest not only because of the biological role $B_{12}$, but also because, aside from species containing carbonyl, phosphine, or porphyrin ligands, $14-20$ this is the first cobalt(I) macroryclic complex to be so characterized. Moreover, the structure is of interest in its own right because of the considerable variations in distances, angles, and displacements that are found in it, compared to those in the cobalt(II) analogue. Cobalt(I) macrocycle complexes are of ten short lived owing to high reactivity with protic solvents or to internal metal- 
ligand decompositions. The species examined here is moderately stable, even moxe so than the cobaloxime parent, $\mathrm{Co}(\mathrm{dmgH})_{2} \mathrm{py}^{-}$. In general cobalt(I) complexes are strong nucleophiles $2,12,13,21-24$ and Bronsted (as well as Lewis) bases. $6-9,24$ Several catalytic reactions of cobalt(I) macrocycles are known. 23-25 


\section{RESULTS AND DISCUSSION}

The pentacoordinated structure of the cobalt(I) monoanion Co(dmgBF $\left.)_{2}\right)_{2} \mathrm{py}^{-}$is depicted in the ORTEP diagram given in Figure VI-1. The structure is square pyramidal. The closest analogues are cobalt(I) porphyrins. 26,27 Most often cobalt(I) needs to be stabllized by co (or phosphine) coordination, $25-30$ as in the trigonal bipyramidal $18 \mathrm{e}$ cobalt(I) compound $\mathrm{Co}\left(\mathrm{BiPh}_{2}\right)(\mathrm{CO})_{3}\left(\mathrm{PPh}_{3}\right) \cdot 16$

The structural refinement of $\left.\mathrm{Co}(\mathrm{dmgBF})_{2}\right)^{-}$establishes that the imine nitrogens, methylene carbons, and oxygens of the $\left(\mathrm{dingBF}_{2}\right)_{2}{ }^{2-}$ macrocycle constitute a base planar $\left(X^{2}=4105\right)$ entity made rigid by the $s p^{2} \mathrm{C}=\mathrm{N}$ hybridization. The cobalt atom is displaced $0.257 \AA$ toward pyridine above the macrocyclic plane. The aromatic plane of pyridine bisects the equatorial plare through the two boron atoms; the two $\mathrm{BF}_{2}$ units are displaced below the equatorial plane, away from the coordinated pyridine. Crystallographic data are summarized in Tables VI-1 and VI-2.

Selected bond lengths and angles are given in Tables VI-3, VI-4 And VI-5. Table VI-5 also contains data for analogous compounds. The bond distance between cobalt(I) to a nitrogen atom of the equatorial ligands $1.839(4) \AA$ is significantly shorter than other $\mathrm{Co}(\mathrm{I})-\mathrm{N}$ eq single bonds (ca. 2.1 $A$, Table VI-5). Moreover the distance is unmistakably shorter than the average $\mathrm{Co}($ II $)-\mathrm{N}_{\text {eq }}$ distance of $1.878(4)$ in the cobalt(II) complex, $\mathrm{Co}(\mathrm{dmgBF})_{2}\left(\mathrm{CH}_{3} \mathrm{OH}\right)_{2}$. In fact, the $\mathrm{Co}(\mathrm{I})-\mathrm{N} e q$ distance in the anion is the shortest distance so far reported.

The short $\mathrm{Co}(\mathrm{I})-\mathrm{N}_{\mathrm{eq}}$ bond distance relative to Co(II)-Neq contradicts what one might have presumed: a considerable bond lengthening should 
attend reduction of cobalt(II) to cobalt(I). The displacement of cobalt(I) above the $\mathrm{N}_{4}$ equatorial plane is therefore not to be attributed to the larger size of the low-valent cobalt ion. Correspondingly, to accommodate the change of the $\mathrm{Co}-\mathrm{N}$ bond distance, the $\mathrm{O}-\mathrm{N}-\mathrm{C}$ (methylene) and $\mathrm{N}-\mathrm{C}($ methylene) $-\mathrm{C}$ (methylene) bond angles in the cobalt(I) anion are smaller (av. $116.3(3)$ and $111.0(4)^{\circ}$, respectively) than those in the cobalt(II) compound (av. $119.76(39)$ and $112.72(42)^{\circ}$, respectively). 31

It is interesting to note that the addition of one extra electron to the $d_{z} 2$ orbital in the cobalt(II) complex is not only accompanied by a reduction in coordination number but also by a decrease in the Co-Neq bond distances. Strengthening of an M-CO bond attending an increase of electron density at the metal center is well known, as it is often reflected by the decrease of $v_{\mathrm{CO}} .{ }^{32}$ similar shortening of the Co-Neq bond in macrocycles is rare, the only example being the carbonyl containing species $\left[\mathrm{Co}(\mathrm{CO})\left(\mathrm{C}_{10} \mathrm{H}_{17} \mathrm{~N}_{8}\right)\right]^{28}$ where $\pi$-backbonding to the equatorial Ifgand was invoked to account for short Co-N bonds. Our data clearly support a similar explanation. We feel this is a particularly clear example since no carbonyl group is involved and since the same Co(dmgBF $)_{2}$ unit has been structurally characterized in both cobalt(I) and (II) oxidation states.

The diamagnetism of the low spin $\mathrm{d}^{8} \mathrm{Co}\left(\mathrm{dmgBF}_{2}\right)_{2} \mathrm{py}^{-}$is conststent with our finding that it has a normal $1_{\mathrm{H}} \mathrm{nmr}$ spectrum and no ESR signal. The diamagnetism of similar cobalt(I), rhodium(I), and iridium(I) compounds is well documented.33-36 There is no evidence of axial hydrogen coordination from the difference Fourier map and refinement. The electron configuration at cobalt should be $\left(d_{x z}\right)^{2}\left(d_{y z}\right)^{2}\left(d_{x y}\right)^{2}\left(d_{z}\right)^{2}$ 
because of the short $\mathrm{Co}^{\mathrm{I}}-\mathrm{N}_{\mathrm{eq}}$ bonds, the absence of a sixth axial ligand, and the diamagnetisn of the complex.

The axial displacement of cobalt may significantly decrease the repulsion between the electron lone pairs of nitrogen atoms in (dmgBF 2$)_{2}$ ligand and the filled $d_{z}$ orbital of the cobalt as the upward displacement of the cobalt from the basal plane results in the nitrogen lone pairs approaching the nodal plane of the $d_{z} 2$ orbital of cobalt. This diminishing antibonding repulsion may contribute to the shortening of the $\mathrm{Co}^{\mathrm{I}}-\mathrm{N}$ eq bonds.

It is also very important to note that the axial displacement of cobalt in $\mathrm{Co}\left(\mathrm{dmgBF}_{2}\right)_{2} \mathrm{py}^{-}$removes the symmetry forbiddeness of the overlap of the cobalt $\mathrm{d}_{z} 2$ orbital with the $\pi_{1}{ }^{*}$ orbital of $\left(\mathrm{dmgBF}_{2}\right)_{2} 37$ which is otherwise present in the cobalt(II) complex. This allows charge transfer (backbonding) to occur in the sense $\operatorname{Co}\left(d_{z} 2\right) \rightarrow\left(\operatorname{dmgBF}_{2}\right)_{2}\left(\pi_{1}^{*}\right)$. The doubly populated $d_{z} 2$ orbital in the cobalt(I) form not only increases the electron density avallable for back donation but also increases the energy of the $d_{z} 2$ orbital making back bonding more energetically favorable.

An extreme of such back donation is an intramolecular electron transfer resulting $\left.\left[\mathrm{CoIII}_{(\mathrm{dmgBF}}\right)_{2} 2^{4-p y}\right]^{-}$or $\left.\left[\mathrm{CoIII}_{(\mathrm{dmgBF}}\right)_{2} 2^{2-} \mathrm{py}^{2-}\right]^{-}$. But we do not belleve the assignment of Co(III) oxidation state to $\left[\mathrm{Co}(\mathrm{dmgBF})_{2}\right]^{-}$to be appropriate. This is because: (1)The deep blue color of $\left[\mathrm{Co}\left(\mathrm{dmgBF}_{2}\right)_{2}\right]^{-}$is known to be associated with $\mathrm{Co}(\mathrm{I})$ oxidation state. Relavent inorganic Co(III) macrocyclic complexes are known to be yellow (e.g., $\left.\mathrm{ClCo}(\mathrm{dmgBF})_{2}{ }_{2} \mathrm{P}\left(\mathrm{C}_{4} \mathrm{H}_{9}\right)_{3}\right)$ or brown (e.g., $\left.\mathrm{ClCo}(\mathrm{dmgBF})_{2} \mathrm{py}\right), 38$ (2)All the known inorganic Co(III) complexes of bis(dimethylglyoximato) 
and bis[(difluoroboryl)dimethylglyoximato] are hexacoordinated to satisfy the $18 \mathrm{e}$ rule. $38-41$ No precedent is found in these groups of Co(III) complexes where cobalt is only pentacoordinated.

Displacement of cobalt above the $\mathrm{N}_{4}$ equatorial plane seems necessary to make such a short $\mathrm{Co}^{\mathrm{I}}-\mathrm{N}_{\text {eq }}$ bond. Such a displacement is also noticed in $\mathrm{Co}(\mathrm{CO})\left(\mathrm{C}_{10} \mathrm{H}_{17} \mathrm{~N}_{8}\right), 28$ where a short $\mathrm{Co}-\mathrm{N}$ bond was observed. On the other hand, consider the case of $\mathrm{Co}^{\mathrm{I}}$ (HDP) (HDP = $2,2,3,3,7,7,8,8,12,12,13,13,17,17,18,18$-hexadecame thy 1 -10,20-diazaoctahydroporphinato) 27 where such a displacement is absent and cobalt is coplanar with the four nitrogen atoms of the equatorial ligand. Even though the ligand contains a more highly conjugated r-system (and is therefore a better electron acceptor) the $\mathrm{Co}^{I_{-}} \mathrm{N}$ bond is still relatively long, $1.91 \AA .27$ This comparison suggests that the metal donor orbital needs to be displaced from the coordination plane in order to function, recommending the notion of the cobalt $d_{z} 2$ orbital being the electron donating orbital.

As shown in Table VI-5, the bond distances betwcen imine nitrogens and adjacent carbons, and those between the pair of adjacent methylene carbons change with oxidation state, such that: $\mathrm{N}-\mathrm{C}(\mathrm{Co} I)>\mathrm{N}-\mathrm{C}\left(\mathrm{Co}^{I I}\right)$ and $\mathrm{C}-\mathrm{C}\left(\mathrm{Co}^{\mathrm{I}}\right)<\mathrm{C}-\mathrm{C}\left(\mathrm{Co}^{\mathrm{II}} \mathrm{I}\right)$. This bond length alternation is indicative of increased electron density in the $\pi^{*}$ (LUMn) orbital of $\left(\mathrm{dmgBF}_{2}\right)_{2}$, apparently as a result of the $\operatorname{Co}\left(\mathrm{d}_{2}\right) \rightarrow\left(\mathrm{dmgBF}_{2}\right)_{2}\left(\pi_{1}^{*}\right)$ backbonding.

Obviously the bond length change within the equatorial ligand cannot be attributed to axial coordination. Moreover the bond parameters of the axial pyridine are normal. 42 The $B F_{2}$ units certainly serve to stabilize 
the cobalt(I) oxidation state via an inductive effect, but no unambiguous comparison can be made based on the structural data. 


\section{EXPERIMENTAL SECTION}

Crystal Growth. The formation of the macrocyclic monoanion $\mathrm{Co}\left(\mathrm{dmgBF}_{2}\right)_{2 \mathrm{py}^{-}}$is recognized by the intense blue coloration ${ }^{40,44}$ that develops. It can be generated either by controlled potential reduction of $i$ ts parent neutral compound $\mathrm{Co}\left(\mathrm{dmgBF}_{2}\right)_{2}\left(\mathrm{H}_{2} \mathrm{O}\right)_{2}$ in acetonitrile in the presence of one equivalent of pyridine at $-0.44 \mathrm{~V}$ (vs $\mathrm{NHE}$ ) or by decomposition of alkyl-Co(dngBF$)_{2} \mathrm{py}^{2-}$ in acetonitrile. Formation of $\mathrm{n}_{-} \mathrm{C}_{3} \mathrm{H}_{7} \mathrm{Co}(\mathrm{dmgBF})_{2} \mathrm{py}^{2-}$ can be achieved by controlled potential electrolysis of $n-\mathrm{C}_{3} \mathrm{H}_{7} \mathrm{Co}(\mathrm{dmgBF})_{2}$ py at $-1.90 \mathrm{~V}$ (vs NHE) in 0.06 $\mathrm{M}\left(\mathrm{CH}_{3}\right)_{4} \mathrm{NBF}_{4}$ acetonitrile solution. An air-free electrocell with a mercury pool working electrode, a platinum plate auxiliary electrode, and an $\mathrm{Ag} / \mathrm{AgCl}$ reference electrode was used to conduct the electrolysis. Owing to much the higher solubility of $\mathrm{n}-\mathrm{C}_{3} \mathrm{H}_{7} \mathrm{Co}(\mathrm{dmgBF} 2)_{2}$ py over $\left.\mathrm{Co}(\mathrm{dmgBF})_{2}\right)_{2}\left(\mathrm{H}_{2} \mathrm{O}_{2}\right.$ in acetonitrile, the second method was adopted to obtain a crystal for this study. A three layer solution system in a test tube was employed for the crystal to grow. Diethyl ether was allowed to diffuse slowly from the top layer through a $\mathrm{C}_{5} \mathrm{H}_{12}$ middle layer into the bottom layer of the dark blue acetonitrile solution containing the title compound, all at $0{ }^{\circ} \mathrm{C}$. The middle layer, which is immiscible with the blue acetonitrile solution on the bottnm. functions as a spacer to slow the diffusion of diethyl ether into the acetonitrile solution and ensure the quality of crystals for the diffraction study. Anaerobic conditions are required owing to the extreme sensitivity of $\mathrm{Co}\left(\mathrm{dngBF}_{2}\right)_{2}$ py- solution toward oxygen. The doep blue crystal of $\left[\left(\mathrm{CH}_{3}\right)_{4} \mathrm{~N}\right]\left[\mathrm{Co}(\mathrm{dmgBF})_{2}\right.$ py $] \cdot \mathrm{CH}_{3} \mathrm{CN}$ is less air sensitive. 
8-Ray Data Collection. A dark blue crystal of the title compound was taken from a nitrogen-filled test tube and attached to the tip of a glass fiber. The crystal was then moved into the cold stream of the lowtemperature device on the diffractometer, and slowly cooled to $-75^{\circ} \mathrm{C}$. The cell constants were determined from a list of reflections found by an automated search routine. Pertinent data collection and reduction information are given in Table VI-1.

A total of 4741 reflections were collected in the $\pm h, k, \pm l$ hemisphere. Lorentz and polarization corrections were applied. An absorption correction based on a series of psi-scans was applied, and equivalent reflections were averaged.

Determination and Refinement of the Structure. The choice of the centric triclinic group was indicated initially by intensity statistics, and later confirmed by the successful refinement of the structure. the positions of all of the non-hydrogen atoms of the complex and the associated counter ion were found by an automatic Patterson interpretation method. 45 One molecule of acetonitrile was later located in a difference Fourier map. In the final stages of refinement, the nonhydrogen atoms were refined with anisotropic temperature factors, and hydrogen atoms were added in idealized positions. A common isotropic temperature factor was refined for each of these groups of hydrogen atoms: one for the methyl hydrogens of the complex, one for the pyridinyl hydrogens, and one for the methyl hydrogen atoms on the $\left[\left(\mathrm{CH}_{3}\right)_{4} \mathrm{~N}\right]^{+}$and $\mathrm{CH}_{3} \mathrm{CN}$ moieties.

X-ray data collection and structure solution were carried out at the Iowa State Molecular Structure Laboratory. Refinement calculations were 
performed on a Digital Equipment Corp. Micro VAX-II computer using the SHELX-76 prograins. 46 
Table VI-1. Crystallographic Data for $\left.\left[\left(\mathrm{CH}_{3}\right)_{4} \mathrm{~N}\right]\left(\mathrm{CO}(\mathrm{dmgBF})_{2}\right)_{2} \mathrm{Py}\right] \cdot \mathrm{CH}_{3} \mathrm{CN}$.

\begin{tabular}{|c|c|}
\hline Forroule & $\mathrm{C}_{28} \mathrm{~B}_{20} \mathrm{~B}_{2} \mathrm{~N}_{6} \mathrm{O}_{4} \mathrm{~F}_{4} \mathrm{Co} \cdot \mathrm{CB}_{3} \mathrm{CN}$ \\
\hline Forwouls weight & 570.02 \\
\hline Space Group & $\mathbf{P I}$ \\
\hline$\bullet, \mathcal{A}$ & $12.182(4)$ \\
\hline$b, \boldsymbol{A}$ & $22.683(3)$ \\
\hline c, $\mathcal{A}$ & $8.096(3)$ \\
\hline$a, \operatorname{deg}$ & $88.39(2)$ \\
\hline$B_{1} \operatorname{deg}$ & $108.35(2)$ \\
\hline q, deg & $103.72(2)$ \\
\hline$v, h^{3}$ & $1280.9(7)$ \\
\hline 2 & 2 \\
\hline$d_{\text {eBlG }} B / c \mathrm{~s}^{3}$ & 9.501 \\
\hline Crystal size, $m$ m & $0.4 \times 0.3 \times 0.2$ \\
\hline$\mu\left({\mathrm{M} O \mathrm{~K}_{0}}_{0}\right), c \mathrm{~cm}^{-1}$ & 7.338 \\
\hline Data collection instrumeat & Earaf-Nonine CADA \\
\hline $\begin{array}{l}\text { Radiation (monoekromated in } \\
\text { incident bears) }\end{array}$ & $\operatorname{MoK}_{0}(\lambda=0.73073 \lambda)$ \\
\hline 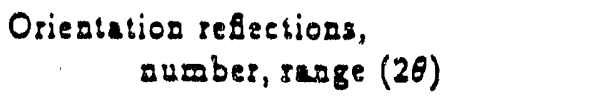 & $1 \theta, 38.2<2 \theta<94.7$ \\
\hline Temperature, $\mathrm{C}$ & $.75(1)$ \\
\hline Sean acthod & witenes \\
\hline Data col. anage, $2 \theta$, deg & $1.0-\$ 0.0$ \\
\hline $\begin{array}{l}\text { No. data colleeted: } \\
\text { No. unique data, } \\
\text { with } F_{0}^{2}>3 \sigma\left(F_{0}^{2}\right) \text { : }\end{array}$ & $\begin{array}{l}4941 \\
4513 \\
3341\end{array}$ \\
\hline Rumber of paszmeters refined & 337 \\
\hline$R^{*}$ & 0.045 \\
\hline$R:$ & 0.081 \\
\hline Qualiky-of-fit indicator & 1.01 \\
\hline Lurgest sbift/esd, fioal eycle & $<0.01$ \\
\hline Largest peak, $e / \lambda^{3}$ & $0.62(8)$ \\
\hline
\end{tabular}


Table VI-2. Positional Parameters of $\left[\left(\mathrm{CH}_{3}\right)_{4} \mathrm{~N}\right]\left[\mathrm{Co}(\mathrm{dmgBF} 2)_{2} \mathrm{py}\right] \cdot \mathrm{CH}_{3} \mathrm{CN}$

\begin{tabular}{|c|c|c|c|c|}
\hline Atom & $\begin{array}{l}x \\
-\end{array}$ & $\begin{array}{l}y \\
-\end{array}$ & $\begin{array}{l}2 \\
-\end{array}$ & $B\left(\Lambda^{2}\right)$ \\
\hline $\operatorname{co}(1)$ & $0.21545(4)$ & $0.27016(4)$ & $0.00770(6)$ & $2.61(1)$ \\
\hline$F(1)$ & $0.0133(2)$ & $0.1333(2)$ & $-0.3952(3)$ & $3.04(7)$ \\
\hline$F(2)$ & $-0.0705(2)$ & $0.2693(2)$ & $-0.4501(3)$ & $3.70(8)$ \\
\hline$F(3)$ & $0.3714(2)$ & $0.0810(2)$ & $0.1245(3)$ & $2.80(6)$ \\
\hline$F(4)$ & $0.4863(2)$ & $0.1802(2)$ & $0.3886(3)$ & $3.06(7)$ \\
\hline$O(1)$ & $0.1290(2)$ & $0.3214(2)$ & $-0.3003(3)$ & $2.42(7)$ \\
\hline$O(2)$ & $-0.0258(2)$ & $0.2426(2)$ & $-0.1963(3)$ & $2.29(7)$ \\
\hline$O(3)$ & $0.2955(2)$ & $0.1829(2)$ & $0.2852(3)$ & $2.30(7)$ \\
\hline $0(4)$ & $0.4527(2)$ & $0.2749(2)$ & $0.2923(3)$ & $2.31(7)$ \\
\hline$N(1)$ & $0.0515(3)$ & $0.2176(2)$ & $-0.0673(4)$ & $1.78(8)$ \\
\hline$N(2)$ & $0.2002(3)$ & $0.1897(3)$ & $0.1554(4)$ & $1.85(8)$ \\
\hline$N(3)$ & $0.3732(3)$ & $0.2853(2)$ & $0.0492(4)$ & $2.95(8)$ \\
\hline$N(4)$ & $0.2232(3)$ & $0.3081(3)$ & $-0.1772(4)$ & $2.01(8)$ \\
\hline$N(5)$ & $0.2407(3)$ & $0.4225(3)$ & $0.1407(4)$ & $2.04(9)$ \\
\hline$c(1)$ & $0.0036(3)$ & $0.1653(3)$ & $0.0208(5)$ & $2.0(1)$ \\
\hline$c(2)$ & $0.0939(3)$ & $0.1493(3)$ & $0.1560(4)$ & $2.0(1)$ \\
\hline$c(3)$ & $0.4198(4)$ & $0.3299(3)$ & $-0.0478(5)$ & $2.2(1)$ \\
\hline$c(4)$ & $0.3286(4)$ & $0.3424(3)$ & $-0.1843(5)$ & $2.2(1)$ \\
\hline$c(5)$ & $-0.1269(4)$ & $0.1254(4)$ & $-0.0178(5)$ & $3.1(1)$ \\
\hline$c(6)$ & $0.0686(4)$ & $0.0932(4)$ & $0.2772(6)$ & $3.5(1)$ \\
\hline$c(7)$ & $0.5496(4)$ & $0.3617(4)$ & $-0.0176(6)$ & $3.1(1)$ \\
\hline
\end{tabular}


Table VI-2. (continued)

\begin{tabular}{lcccc} 
Atod & $x$ & $y$ & $z$ & $B\left(A^{2}\right)$ \\
\hdashline$C(8)$ & $0.3494(4)$ & $0.3843(4)$ & $-0.3207(5)$ & $3.4(1)$ \\
$C(11)$ & $0.1794(4)$ & $0.4875(3)$ & $0.0770(5)$ & $2.8(1)$ \\
$C(12)$ & $0.1921(4)$ & $0.5909(4)$ & $0.1644(6)$ & $3.7(1)$ \\
$C(13)$ & $0.2732(5)$ & $0.6304(4)$ & $0.3261(6)$ & $3.7(1)$ \\
$C(14)$ & $0.3386(4)$ & $0.5654(4)$ & $0.3915(5)$ & $3.3(1)$ \\
$C(15)$ & $0.3200(4)$ & $0.4621(3)$ & $0.2966(5)$ & $2.6(1)$ \\
$B(1)$ & $0.0136(4)$ & $0.2400(4)$ & $-0.3348(5)$ & $2.4(1)$ \\
$B(2)$ & $0.3993(4)$ & $0.2795(4)$ & $0.2435(5)$ & $2.2(1)$ \\
$N(6)$ & $0.3308(3)$ & $-0.0035(3)$ & $-0.3228(4)$ & $2.34(9)$ \\
$C(21)$ & $0.2385(4)$ & $0.0515(4)$ & $-0.3199(6)$ & $3.3(1)$ \\
$C(22)$ & $0.3144(4)$ & $-0.1002(4)$ & $-0.2514(5)$ & $3.0(1)$ \\
$C(23)$ & $0.4528(4)$ & $0.0766(4)$ & $-0.2291(6)$ & $3.5(1)$ \\
$C(24)$ & $0.3165(4)$ & $-0.0436(4)$ & $-0.4972(5)$ & $3.0(1)$ \\
$N(7)$ & $0.8121(6)$ & $0.3497(6)$ & $0.2190(9)$ & $9.0(3)$ \\
$C(31)$ & $0.9116(6)$ & $0.3823(6)$ & $0.2816(8)$ & $5.8(2)$ \\
$C(32)$ & $1.0392(6)$ & $0.4204(6)$ & $0.3562(9)$ & $6.7(2)$
\end{tabular}

Anisotropically refined atoms are given in the form of the isotropic equivalent displacement parameter defined as: $(4 / 3) \star 1 a^{2} \star B(1,2)+b^{2} \star B(2,2)+c^{2} \star B(3,3)+b(\cos g 2 \pi n a) * B(1,2)$ $+a(\cos$ be $\{a) \star B(1,3)+b c(\cos$ alpha $) \star B(2,3)]$ 
Table VI-3. Bond Distances $\left(d / 10^{-10} \mathrm{~m}\right)$ and their Standard Deviations of $\left[\left(\mathrm{CH}_{3}\right){ }_{4} \mathrm{~N}\right][\mathrm{CO}(\mathrm{dmgBF} 2) 2 \mathrm{Py}] \cdot \mathrm{CH}_{3} \mathrm{CN}$.

\begin{tabular}{|c|c|c|c|c|c|}
\hline $\begin{array}{l}\text { Atom } 1 \\
-\infty \operatorname{cosex}\end{array}$ & $\begin{array}{l}\text { Arow } 2 \\
-\infty \ldots=-\infty\end{array}$ & $\begin{array}{l}\text { Disiance } \\
\text { anmman }\end{array}$ & $\begin{array}{l}\text { Atow } 1 \\
-\infty\end{array}$ & $\begin{array}{l}\text { Arod } 2 \\
-0=\infty\end{array}$ & $\begin{array}{l}\text { D1stance } \\
\text { atem= }\end{array}$ \\
\hline $\operatorname{Co}(1)$ & $N(1)$ & $1.842(3)$ & $N(4)$ & $c(4)$ & $1.312(6)$ \\
\hline $\operatorname{Co}(1)$ & $N(2)$ & $1.844(4)$ & $N(5)$ & $c(11)$ & $1.337(6)$ \\
\hline $\operatorname{co}(1)$ & $N(3)$ & $1.836(3)$ & $N(5)$ & $C(15)$ & $1.349(4)$ \\
\hline $\operatorname{Co}(1)$ & $N(4)$ & $1.834(4)$ & $c(1)$ & $c(2)$ & $2.443(3)$ \\
\hline $\operatorname{Co}(1)$ & $N(5)$ & $2.019(3)$ & $c(1)$ & $c(5)$ & $1.488(6)$ \\
\hline$F(2)$ & $B(1)$ & $1.393(6)$ & $c(2)$ & $c(6)$ & $1.479(7)$ \\
\hline$F(2)$ & $B(1)$ & $1.385(6)$ & $c(3)$ & $C(4)$ & $1.436(5)$ \\
\hline$F(3)$ & $B(2)$ & $1.407(5)$ & $c(3)$ & $c(7)$ & $1.494(6)$ \\
\hline$F(4)$ & $B(2)$ & $1.393(5)$ & $c(4)$ & $c(8)$ & $1.491(7)$ \\
\hline$O(1)$ & $N(4)$ & $1.392(4)$ & $c(11)$ & $c(12)$ & $1.375(6)$ \\
\hline$O(1)$ & $B(1)$ & $1.468(5)$ & $c(12)$ & $c(13)$ & $1.394(6)$ \\
\hline$O(2)$ & $N(d)$ & $2.384(4)$ & $c(13)$ & $c(14)$ & $1.373(7)$ \\
\hline$O(2)$ & $B(1)$ & $2.481(6)$ & $c(14)$ & $c(15)$ & $1.380(6)$ \\
\hline $0(3)$ & $N(2)$ & $1.398(4)$ & $N(6)$ & $c(21)$ & $1.495(7)$ \\
\hline$O(3)$ & $B(2)$ & $2.472(6)$ & $N(6)$ & $c(22)$ & $1.495(6)$ \\
\hline $0(4)$ & $N(3)$ & $1.392(4)$ & $N(6)$ & $c(23)$ & $1.490(5)$ \\
\hline $0(4)$ & $B(2)$ & $1.472(6)$ & $N(6)$ & $c(24)$ & $2.506(6)$ \\
\hline$N(d)$ & $c(1)$ & $1.317(6)$ & $N(7)$ & $C(31)$ & $1.12(1)$ \\
\hline$N(2)$ & $c(2)$ & $1.309(5)$ & $c(31)$ & $c(32)$ & $1.43(1)$ \\
\hline$N(3)$ & $c(3)$ & $2.330(6)$ & & & \\
\hline \multicolumn{6}{|c|}{$\begin{array}{l}\text { Numbers in parentheses are estimated standard deviations in } \\
\text { the least significant digits. }\end{array}$} \\
\hline
\end{tabular}


Table VI-4. Bond Angles (degrees) and their Standard Deviations of $\left[\left(\mathrm{CH}_{3}\right)_{4} \mathrm{~N}\right]\left[\mathrm{Co}(\mathrm{dmgBF} 2)_{2} \mathrm{Py}\right] \cdot \mathrm{CH}_{3} \mathrm{CN}$

\begin{tabular}{|c|c|c|c|c|c|c|c|}
\hline Atos 1 & $\begin{array}{l}\text { Atod } 2 \\
-\infty=0+\infty\end{array}$ & Arod 3 & Angle & $\begin{array}{l}\text { Alon } 1 \\
\text { - }\end{array}$ & $\begin{array}{l}\text { Atu } 2 \\
-\infty\end{array}$ & $\begin{array}{l}\text { AtOE } 3 \\
-000=0\end{array}$ & Angle \\
\hline$N(1)$ & $\operatorname{Co}(2)$ & $N(2)$ & $80.7(1)$ & $O(1)$ & $N(4)$ & $c(4)$ & $215.8(3)$ \\
\hline$N(1)$ & $\operatorname{Co}(1)$ & $N(3)$ & $164.4(1)$ & $\operatorname{Co}(1)$ & $N(5)$ & $c(21)$ & $121.1(2)$ \\
\hline$N(1)$ & $\operatorname{Co}(1)$ & $N(4)$ & $96.6(1)$ & $\operatorname{Co}(1)$ & $N(5)$ & $c(13)$ & $121.1(3)$ \\
\hline$N(1)$ & $\operatorname{Co}(1)$ & $N(5)$ & $98.5(1)$ & $c(11)$ & $N(5)$ & $c(15)$ & $127.8(3)$ \\
\hline$N(2)$ & $\operatorname{Co}(1)$ & $N(3)$ & $96.9(2)$ & $N(1)$ & $c(1)$ & $c(2)$ & $112.1(4)$ \\
\hline$N(2)$ & $\mathrm{Co}(1)$ & $N(4)$ & $162.4(1)$ & $N(1)$ & $c(1)$ & $c(5)$ & $224.1(4)$ \\
\hline$N(2)$ & $\operatorname{Co}(1)$ & $N(5)$ & $99.7(1)$ & $c(2)$ & $c(1)$ & $c(5)$ & $224.7(4)$ \\
\hline$N(3)$ & $\operatorname{Co}(1)$ & $N(4)$ & B.. $0(2)$ & $N(2)$ & $c(2)$ & $c(1)$ & $111.0(4)$ \\
\hline$N(3)$ & $\operatorname{Co}(1)$ & $N(5)$ & $97.0(1)$ & $N(2)$ & $c(2)$ & $c(6)$ & $124.9(4)$ \\
\hline$N(4)$ & $C o(1)$ & $N(5)$ & $97.9(1)$ & $c(1)$ & $c(2)$ & $c(6)$ & $124.2(4)$ \\
\hline$N(4)$ & $O(1)$ & $B(2)$ & $123.0(3)$ & $N(3)$ & $c(3)$ & $C(4)$ & $110.9(4)$ \\
\hline$N(d)$ & $O(2)$ & $B(1)$ & $122.9(3)$ & $N(3)$ & $c(3)$ & $6(7)$ & $124.1(4)$ \\
\hline$N(2)$ & $0(3)$ & $B(2)$ & $112.8(3)$ & $c(4)$ & $c(3)$ & $c(7)$ & $125.2(4)$ \\
\hline$N(3)$ & $O(4)$ & $B(2)$ & $111.9(2)$ & $N(4)$ & $C(4)$ & $c(3)$ & $111.2(4)$ \\
\hline $\mathrm{Co}(1)$ & $N(1)$ & $O(2)$ & $224.7(3)$ & $N(4)$ & $C(4)$ & $c(8)$ & $124.1(4)$ \\
\hline $\mathrm{Co}(1)$ & $N(1)$ & $c(1)$ & $118.0(2)$ & $c(3)$ & $C(4)$ & $c(8)$ & $124.7(4)$ \\
\hline$O(2)$ & $N(1)$ & $c(1)$ & $116.5(3)$ & $N(5)$ & $c(11)$ & $c(12)$ & $122.9(4)$ \\
\hline $\operatorname{Co}(2)$ & $N(2)$ & $O(3)$ & $224.9(2)$ & $c(11)$ & $C(12)$ & $c(23)$ & $118.8(5)$ \\
\hline$C O(2)$ & $N(2)$ & $c(2)$ & $118.3(3)$ & $c(12)$ & $c(13)$ & $C(14)$ & $118.7(4)$ \\
\hline$O(3)$ & $N(2)$ & $c(2)$ & $116.0(3)$ & $c(13)$ & $C(14)$ & $c(15)$ & $219.1(4)$ \\
\hline $\operatorname{Co}(1)$ & $N(3)$ & $0(4)$ & $124.2(3)$ & $N(5)$ & $c(15)$ & $c(14)$ & $222.6(4)$ \\
\hline $\operatorname{Co}(1)$ & $N(3)$ & $c(3)$ & $127.5(3)$ & $F(1)$ & $B(1)$ & $F(2)$ & $110.7(3)$ \\
\hline
\end{tabular}


Table VI-4. (continued)

\begin{tabular}{|c|c|c|c|c|c|c|c|}
\hline Atod 1 & Atom 2 & Atom 3 & Angle & Acom 1 & $\begin{array}{c}A \operatorname{com} 2 \\
-\infty n+\infty\end{array}$ & $\begin{array}{l}\text { Atom } 3 \\
m=-\infty=m\end{array}$ & Angle \\
\hline $0(4)$ & $N(3)$ & $c(3)$ & $217.0(3)$ & $F(1)$ & $B(1)$ & $O(1)$ & $120.7(4)$ \\
\hline $\operatorname{Co}(1)$ & $N(4)$ & $O(1)$ & $125.1(3)$ & $F(1)$ & $B(1)$ & $O(2)$ & $109.5(4)$ \\
\hline $\operatorname{Co}(1)$ & $N(4)$ & $c(4)$ & $118.2(3)$ & $F(2)$ & $B(1)$ & $O(1)$ & $205.6(4)$ \\
\hline$F(2)$ & $B(1)$ & $0(2)$ & $104.7(4)$ & $c(21)$ & $N(6)$ & $c(22)$ & $109.9(4)$ \\
\hline$O(1)$ & $B(1)$ & $O(2)$ & $115.4(3)$ & $c(21)$ & $N(6)$ & $c(23)$ & $220.3(3)$ \\
\hline$F(3)$ & $B(2)$ & $F(4)$ & $109.5(4)$ & $c(21)$ & $N(6)$ & $C(24)$ & $108.8(3)$ \\
\hline$F(3)$ & $B(2)$ & $0(3)$ & $110.4(3)$ & $c(22)$ & $N(6)$ & $c(23)$ & $209.9(3)$ \\
\hline$F(3)$ & $B(2)$ & $0(4)$ & $109.6(4)$ & $c(22)$ & $N(6)$ & $c(24)$ & $109.2(3)$ \\
\hline$F(4)$ & $B(2)$ & $O(3)$ & $104.5(4)$ & $c(23)$ & $N(6)$ & $C(24)$ & $108.8(4)$ \\
\hline$E(4)$ & $8(2)$ & $0(4)$ & $106.0(3)$ & $N(7)$ & $c(31)$ & $c(32)$ & $177.5(9)$ \\
\hline$O(3)$ & $B(2)$ & $0(4)$ & $116.5(4)$ & & & & \\
\hline
\end{tabular}

Numbers in parentheses are estimated siandard deviations in the least significant diglis. 


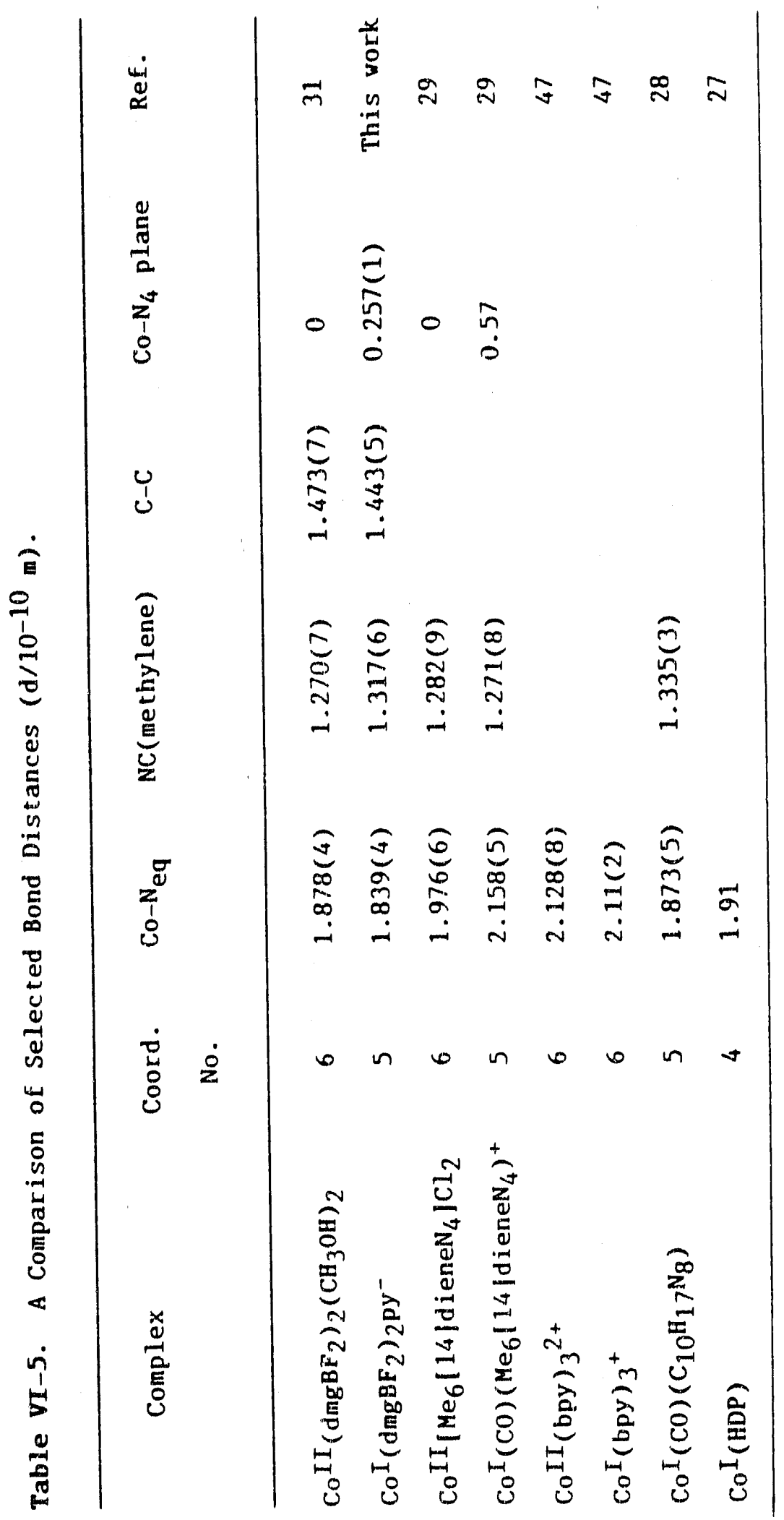




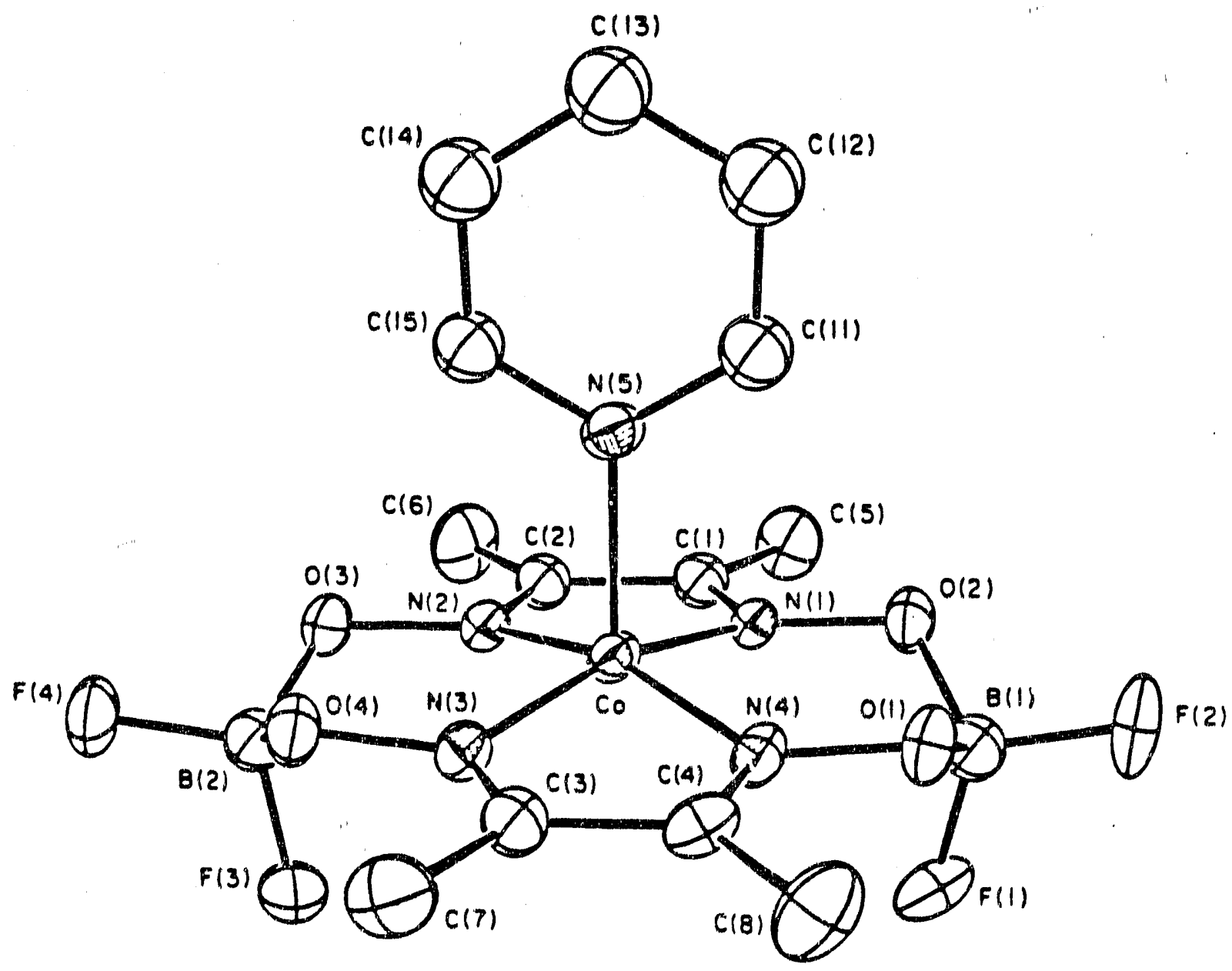

Rigure VI-1. An ORTEP view of the monoanion, $\mathrm{CoI}^{\mathrm{I}}\left(\mathrm{dmgBF}_{2}\right)_{2} \mathrm{py}^{-}$ 


\section{REFERENCES}

(1) (a) Schrauzer, G.N. Acc. Chem. Res. 1968, 1, 97 . (b) Schrauzer, G.N. Pure Appl. Chem. 1973, 33, 545. (c) Jaselskis, B.; Dieh1, H. J. Am. Chem. Soc. 1954, 76, 4345; For revlews see: (d) Pratt, J. M. "Inorganic Chemistry of V1tamin B12", Academic Press, New York, 1972; (e) Smith, E. L. "Vitamin B12", Third Edition, Methuen \& Co., London, 1965.

(2) Krautler, B.; Keller, W.; Kratky, C. I. Am. Chem. Soc. 1989, 111, 8936.

(3) Lexa, D.; Savéant, J. M. J. Am. Chem. Soc. 1976, 98, 2652.

(4) Lexa, D.; Savéant, J. M. J. Chem. Soc. Chem. Commun. 1975, 872.

(5) Lexa, D.; Savéant, J. M. Acc. Chem. Res. 1.983, 16, 235.

(6) Schrauzer, G. N.; Holland, R. J. J. Am. Chem. Soc. 1971, 93, 4060.

(7) Schrauzer, G. N.; Windgassen, R. J.; Kohnle, Chem. Ber. 196.5, 98, 3324.

(8) Schrauzer, G. N.; Holland, R. J. J. Am. Chem. Soc. 1972, 93, 1505.

(9) Chao, T..H.; Espenson, J. H. J. Am. Chem. Soc. 1978, 100, 129.

(10) Johnson, M. D.; Meeks, B. S. J. Chem. Soc. B, 1971, 185.

(11) Naumberg, M.; Duong, K. N. V.; Gaudemer, A. J. Organometal. Chem. $1970,2,231$.

(12) Dodd, D.; Johnson, M. D. J. Organometal. Chem. 1973, 52, 1-232.

(13) Schrauzer, G. N. Ann. N. Y. Acad. Scj. 1969, 158, 526.

(14) Ananias de Carvalho, L. C.; Dartiguenave, M.; Dartiguenave, Y.; J. Organomet. Chem. 1989, 367, 187. 
(15) Hohman, W. H.; Kountz, D. J.; Meek, D. W. Inorg. Chem. 1986, 25, 616.

(16) Calderazzo, F.; Poli, R.; Pelizzi, G. J. Chem. Soc., Dalton Trans. $1984,2535$.

(17) Loghry, R.; Simonsen, S. H. Inorg. Chem. 1978, 17, 1986.

(18) Whitfield, J. M.; Watkins, S. F.; Tupper, G. B.; Baddley, W. H. J. Chem. Soc., Dalton Trans. 1977, 407.

(19) Zhang, Z. Z.; Wang, H. K.; Xi, Z.; Yao, X. K.; Wang, R. J. J. Organomet. Chem. 1989, 376, 123.

(20) Habadie, N.; Dartiguenave, M.; Dartiguenave, Y. Organometallics $1989,8,2564$.

(21) Ochiai,E.; Long, K. M.; Sperati, C. R.; Busch, D. H. J. Am. Chem. Soc. 1969, 91, 3201 .

(22) Farmery, K.; Busch, D. H. Inorg. Chem. 1972, 11, 2901.

(23) Costa, G.; Puxeddu, A.; Reisenhofer, E. J. Chem. Soc., Dalton Trans. 1973, 2034.

(24) Connolly, P.; Espenson, J. H. Inorg. Chem. 1986, 25, 2684.

(25) Fleischer, E. B.; Krishnamurthy, M. J. Am. Chem. Soc. 1972, 94 , 1382 .

(26) Doppelt, P.; Fischer, J.; Weiss, R. Inorg. Chem. 1984, 23, 2958.

(27) Walder, L.; Rytj, G.; Vogeli, U.; Scheffold, R. Helv. Chim. Acta $1984,67,1801$.

(28) Goedken, V. L.; Peng, S.-M. J. Chem. Soc., Chem Comm. 1974, 914.

(29) Szalda, D. D. J.; Fujita, E.; Creutz, C. Inorg. Chem. 1989, 28, 1446. 
(30) The structurally characterized compound $\mathrm{CoPC}_{25} \mathrm{H}_{45} \mathrm{~N}_{5} \mathrm{O}_{4}$ was reported as a cobalt(I) complex; Adams, W. W.; Lenhart, P. G. Acta Cryst. 1973, B24, 2412, but it is actually a cobalt(III) derivative.

(31) Bakac, A.; Brynildson, M. E.; Espenson, J. H. Inorg. Chem. 1986, 25, 408 .

(32) For example, see Lukehart, C. M.; "Fundamental Transtion Metal Organometallic Chemistry" p. 40, Brocks/Cole Publishing Company, Monterey, 1985 and Lisic, E. C.; Hanson, B. E. Organometallics $1987, \underline{6}, 512$.

(33) Rigo, P.; Bressan, M. J. Inorg. Nucl. Chem. 1975, 37, 1812.

(34) Rigo, P.; Bressan, M. Inorg. Nucl. Chem. Lett. 1973, 9, 527.

(35) Schrauzer, G. N. Chem. Ber. 1962, 95, 1438; Also see ref. 1(a).

(36) Slephens, F. S.; Vagg, R. S. Acta Cryst. 1977, B33, 3159.

(37) The conjugated $\pi$-bond $-\mathrm{N}=\mathrm{C}\left(\mathrm{CH}_{3}\right) \mathrm{C}\left(\mathrm{CH}_{3}\right)=\mathrm{N}$ - is viewed as similar to that of butadiene. $\pi_{1}$ * refers to the LUMO orbital of this $\pi$ sys tem.

(38) Ramasami, T.; Espenson, J. H. Inorg. Chem. 19R9, 19, 1523.

(39) Tyrlik, S. K.; Lenstra, A. T. H.; VanLoock, J. F. J.; Geise, H. J. Acta Cryst. 1986, C42, 553.

(40) Attia, M. W.; Zangrando, E.; Randaccio, L.; Lopez, C. Acta Cryst. 1987, C43, 1521.

(41) Lopez, C.; Alvarez, S.; Aguilo, M.; Solans, X.; Font-Altaba, M.; Inorg. Chim. Acta 1987, 127, 153.

(42) af. data in Adains, W. W.; Lenhert, P. G. Acta Cryst. 1.973, B29, 2412 . 
(43) Schrauzer, G. N.; Weber, J. H.; Beckham, T. M. J. Am. Chem. Soc. $1970,92,7078$.

(44) Ramasami, T.; Espenson, J. H. Inorg. Chem. 1980, 19, 1523.

(45) SHELXS-86, Sheldrick, G. M. Institut für Anorganische Chemie der Universität, Göttingen, Germany .

(46) SHELX-76, Sheldrick, G. M., in "Computing in Crystallography", Schenk, H.; Olthof-Hazekamp, R.; Van Keningsveld, H.; Bassi, G. C., Eds., Delft University, Delft, 1978.

(47) Szalda, D. J.; Creutz, C.; Mahajan, D.; Sutin, N. Inorg. Chem. $1983,22,2372$. 
GENERAL SUMMARY

In Part I, kinetics studies were ione of the homolytic and heterolytic cleavage reactions of the chromium-carbon bonds in the complexes $\operatorname{RCr}(L) A^{n+}$ (where $L=[15] \operatorname{aneN}_{4}=$ 1,4,8,12--tetraazacyclopentadecane; $A=\mathrm{H}_{2} \mathrm{O}$, and $\left.\mathrm{OH}^{-\prime}\right)$. Activation parameters $\left(\Delta \mathrm{H}^{\ddagger} / \mathrm{kJ} \mathrm{mol}^{-1}, \Delta \mathrm{S}^{\dagger} / \mathrm{J} \mathrm{mol}^{-1} \mathrm{~K}^{-1}\right.$ ) for homolysis of $\mathrm{RCrL}\left(\mathrm{H}_{2} \mathrm{O}\right)^{2+}$ are: $111 \pm 2,54 \pm 6\left(\mathrm{R}=\mathrm{p}-\mathrm{CH}_{3} \mathrm{C}_{6} \mathrm{H}_{4} \mathrm{CH}_{2}\right) ; 103 \pm 2,28 \pm 5\left(\mathrm{C}_{6} \mathrm{H}_{5} \mathrm{CH}_{2}\right) ; 101$ $\pm 3,22 \pm 9\left(\mathrm{p}-\mathrm{BrC}_{6} \mathrm{H}_{4} \mathrm{CH}_{2}\right)$; and $110 \pm 3,62 \pm 6\left(\mathrm{R}=1-\mathrm{C}_{3} \mathrm{H}_{7}\right)$. The $\Delta \mathrm{H}^{\mathrm{t}}$ and $\Delta S \neq$ parameters are considerably smaller than those for homolysis of $\left(\mathrm{H}_{2} \mathrm{O}\right)_{5} \mathrm{CrR}^{2+}$ analogues. Primary alkyl macrocyclic complexes do not undergo homolysis. The complexes $\mathrm{RCrL}(\mathrm{OH})+$ slowly hydrolyze for $\mathrm{R}=\mathrm{n}-\mathrm{Pr}$ and $i-\mathrm{Pr}$, whereas those for which $\mathrm{R}=\mathrm{ArCH}_{2}$ do not. The activation parameters for heterolysis are $78 \pm 1,-53 \pm 2\left(R=1-C_{3} H_{7}\right)$ and $83 \pm 3$, $-46 \pm 9(n-P r)$. This pathway shows no solvent deuterium isotope effect. The complexes $\mathrm{RCrL}\left(\mathrm{H}_{2} \mathrm{O}\right)^{2+}$ are not subject to acidolysis by $\mathrm{H}_{3} \mathrm{O}^{+}$or: $\mathrm{H}_{2} \mathrm{O}$, unlike their $\left(\mathrm{H}_{2} \mathrm{O}\right){ }_{5} \mathrm{CrR}^{2+}$ analogues.

In Part II, the kinetic studies on the reaction of $\left[\operatorname{RCr}\left([15] \text { aneN }_{4}\right)\left(\mathrm{H}_{2} \mathrm{O}\right)\right]^{2+}$ hereafter $\operatorname{RCrL}\left(\mathrm{H}_{2} \mathrm{O}\right)^{2+}\left(\mathrm{R}=\mathrm{CH}_{3}, \mathrm{C}_{2} \mathrm{H}_{5}, 1-\mathrm{C}_{3} \mathrm{H}_{7}\right.$, $1-\mathrm{C}_{4} \mathrm{H}_{9}, 4-\mathrm{BrC}_{6} \mathrm{H}_{4} \mathrm{CH}_{2}$ ) macrocycles with indine show that the reactivity changes as a function of the nature of the organic group bound to chromium(III). In the case of primary alkylchromium(III) macrocycles, the reaction proceeds strictly by bimolecular electrophilic substitution. The specific rates are $4.7 \times 10^{3} \mathrm{M}^{-1} \mathrm{~s}^{-1}\left(\mathrm{R}=\mathrm{CH}_{3}\right), 81\left(\mathrm{C}_{2} \mathrm{H}_{5}\right), 12$ $\left(1-\mathrm{C}_{3} \mathrm{H}_{7}\right), 8.9\left(1-\mathrm{C}_{4} \mathrm{H}_{9}\right)$, and $9.5\left(4-\mathrm{BrC}_{6} \mathrm{H}_{4} \mathrm{CH}_{2}\right)$. In the case of aralkyl- 
and secondary alkylchromium(III) macrocycles, however, both the normal electrophilic substitution and an oxidatively-induced chain reaction mechanism are operative. Details of the chain reaction for $\mathrm{R}=\mathrm{BrC}_{6} \mathrm{H}_{4} \mathrm{CH}_{2}$ are reported. The rate constant for the formation of $4-\mathrm{BrC}_{6} \mathrm{H}_{4} \mathrm{CH}_{2} \mathrm{CrL}\left(\mathrm{H}_{2} \mathrm{O}\right)^{2+}$ from $\mathrm{CrL}\left(\mathrm{H}_{2} \mathrm{O}\right)^{2+}$ and $4-\mathrm{BrC}_{6} \mathrm{H}_{4} \mathrm{CH}_{2} \mathrm{Br}$ was also determined, $l i=3.7 \times 10^{4} \mathrm{M}^{-1} \mathrm{~s}^{-1}$. The crystal and molecular structure of $\left[4-\mathrm{BrC}_{6} \mathrm{H}_{4} \mathrm{CH}_{2} \mathrm{CrL}\left(\mathrm{H}_{2} \mathrm{O}\right)\right]^{2+}\left(\mathrm{ClO}_{4}\right)_{2} \cdot \mathrm{THF}$ was determined. The molecule crystallizes in the space group $\mathrm{P} 2{ }_{1} / \mathrm{c}$. Cell parameters are $a=11.683(3)$ $\AA, b=8.816(3) \AA, c=29.959(8) \AA, \beta=96.29(11)^{\circ}$. The chromium is octahedrally coordinated by four $\mathrm{N}$ atoms of the macrocyclic ligand at the equatorial positions and by the $4-\mathrm{BrC}_{6} \mathrm{H}_{4} \mathrm{CH}_{2}$ and a water molecule at the axial positions.

Part III concerns the oxidation of organochromium(III) complexes by dihalide and pseudo-dihalide radical anions generated by pulse radiolysis.

$$
\begin{array}{ll}
\text { Pulse radiolysis } & \mathrm{e}^{-}(\mathrm{aq} \cdot)+\mathrm{N}_{2} \mathrm{O}+\mathrm{H}_{2} \mathrm{O} \longrightarrow \mathrm{HO}^{-}+\mathrm{HO}^{-}+\mathrm{N}_{2} \\
\text { Conversion } & \mathrm{HO}^{-}+2 \mathrm{X}^{-} \longrightarrow \mathrm{HO}^{-}+\mathrm{X}_{2}^{-} \\
\text {Reaction } & \mathrm{X}_{2}^{-}+\mathrm{RCrL}\left(\mathrm{H}_{2} \mathrm{O}^{2+} \longrightarrow 2 \mathrm{X}^{-}+\mathrm{RCrL}\left(\mathrm{H}_{2} \mathrm{O}\right)^{3+}\right.
\end{array}
$$

Results suggest an ion pairing process prior to the electron transfer step. The reactivity trend is discussed on the basis of the oxidation of a series of organochromium complexes by three radical anions. 
In Part IV the complex SSRS-

$\left[4-\mathrm{BrC}_{6} \mathrm{H}_{4} \mathrm{CH}_{2} \mathrm{Cr}(1,4,8,12 \text {-tetrazacyclopentadecane })\left(\mathrm{H}_{2} 0\right)\right]^{2+}$, abbreviated $\left[\operatorname{RCrL}\left(\mathrm{H}_{2} \mathrm{O}\right)^{2+}\right]$, is oxidized to $\left[\operatorname{RCrL}\left(\mathrm{H}_{2} \mathrm{O}\right)^{3+}\right]$, a species which then rapidly homolyzes. Rate constants were determined in aqueous solution at $25.0^{\circ} \mathrm{C}$ for oxidation by $\mathrm{ABTS}^{-}-, \mathrm{Fe}\left(\mathrm{H}_{2} \mathrm{O}_{6}{ }^{3+}\right.$, and $\mathrm{IrCl}_{6}{ }^{2-}$; values are $(1.55 \pm$ $0.11) \times 10^{2}, 3.09 \pm 0.28$, and $(1.29 \pm 0.11) \times 10^{4} \mathrm{Lmol}^{-1} \mathrm{~s}^{-1}$. From these data the following estimates were made for the couple $\operatorname{RCrL}\left(\mathrm{H}_{2} \mathrm{O}\right)^{3+/ 2+}: \quad E^{0}=0.76 \pm 0.13 \mathrm{~V}, 5 \times 10^{-2}<\mathrm{k}_{\mathrm{SER}}<7 \times 10^{2} \mathrm{~L} \mathrm{~mol}^{-1} \mathrm{~s}^{-}$ 1. Oxidations of a series of $\operatorname{RCrL}\left(\mathrm{H}_{2} \mathrm{O}\right)^{2+}$ complexes by $\mathrm{IrCl}_{6}{ }^{2-}$ were examined, with rate constants between $2.20 \times 10^{-1} \mathrm{Lmol}^{-1} \mathrm{~s}^{-1}\left(\mathrm{R}=\mathrm{CH}_{3}\right)$ and $4.60 \times 10^{5}\left(\mathrm{R}=4-\mathrm{CH}_{3} \mathrm{C}_{6} \mathrm{H}_{4} \mathrm{CH}_{2}\right)$. Rate constants for the aralkyl series fit a Hammett correlation with $\rho=-4.3$. A lower limit was set on the rate constant for homolysis of $4-\mathrm{BrC}_{6} \mathrm{H}_{4} \mathrm{CH}_{2} \mathrm{CrL}\left(\mathrm{H}_{2} \mathrm{O}\right)^{3+}$ of $\mathrm{k}>60 \mathrm{~s}^{-1}$.

In Part $V$, the study is extended to organocobalt complexes with attention turned to reduction induced cleavages of a transition metalcarbon bond. A series of organocobalt complexes were synthesized by a nucleophilic substitution, $\mathrm{Cc} \mathrm{I}_{\mathrm{L}^{\prime-}}+\mathrm{RX} \longrightarrow \mathrm{RCo} \mathrm{III}_{\mathrm{L}^{\prime}}+\mathrm{X}^{-}$. Electrochemical methods in conjunction with ESR, NMR, and GC-MASS are used to reveal evidence of novel reactions - reduction induced hydrogen atom transfer from the cobalt bound alkyl group to the equatorial ligand, $L^{\prime}$, and reduction induced alkyl group migration from cobalt to the equatorial ligand. 


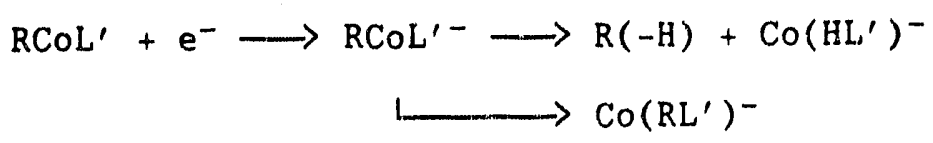

In Part VI, the following compound, $\left[\left(\mathrm{CH}_{3}\right)_{4} \mathrm{~N}\right]\left[\mathrm{Co}\left(\mathrm{dmgBF}_{2}\right)_{2} \mathrm{py}\right]$, where py $=\mathrm{C}_{5} \mathrm{H}_{5} \mathrm{~N}$ and $\left(\mathrm{dmgBF}_{2}\right)_{2}{ }^{2-}=$ bis $[$ (difluoroboryl)dimethylglyoximato], was crystallized, and its molecular structure determined by X-ray diffraction. The distances between $C o(I)$ and the nitrogen of the macrocycle are unusually short $(1.839 \AA)$, even shorter than the corresponding bond $(1.878 \AA$ ) in the cobalt(II) analogue. The cobalt atom is displaced $0.257 \AA$ above the axial plane toward pyridine. Reasons of this unusual Co-N bond shortening is discussed along with the electronic structure of the $d^{8}$ cobalt(I) anion. 


\section{ACRNONLEDGEMENTS}

Many thanks go to professor James H. Espenson for his guidance, encouragement, great patience and understanding during the author's graduate career. The author owes a lot to his parents, and his wife S.H. Zeng for their love and constant support. Many thanks also go to Dr. Andreja Bakac and all the other members of Dr. Espenson's group for their friendship and assistance.

The author is grateful to the excellent instrument services of the Department of Chemistry, Iowa State University.

This work was performed at Ames Laboratory under contract no. W7405-eng-82 with the U.S. Department of Energy. The United States government has assigned the DOE Report number IS-T 1493 to this thesis. 

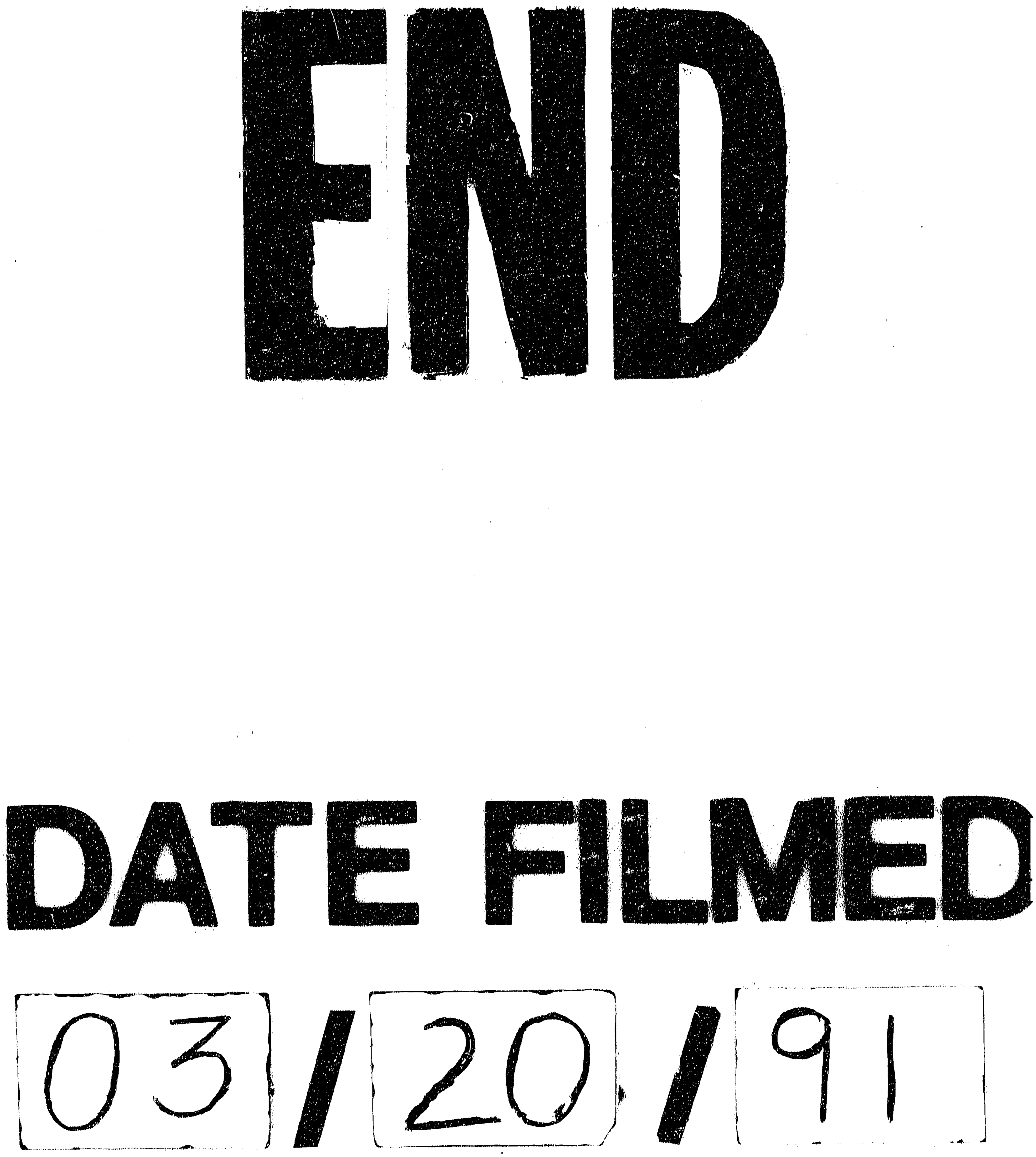


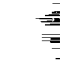

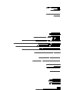

